UNIVERSIDADE DE SÃO PAULO

FACULDADE DE FILOSOFIA, LETRAS E CIÊNCIAS HUMANAS

DEPARTAMENTO DE HISTÓRIA

PROGRAMA DE PÓS-GRADUAÇÃO EM HISTÓRIA SOCIAL

MURYATAN SANTANA BARBOSA

A África por ela mesma: a perspectiva africana na História Geral da África (UNESCO)

\footnotetext{
(versão corrigida)

O exemplar original se encontra disponível no CAPH da FFLCH (Centro de Apoio à Pesquisa Histórica)
}

São Paulo 
UNIVERSIDADE DE SÃO PAULO

FACULDADE DE FILOSOFIA, LETRAS E CIÊNCIAS HUMANAS

DEPARTAMENTO DE HISTÓRIA

PROGRAMA DE PÓS-GRADUAÇÃO EM HISTÓRIA SOCIAL

\title{
A África por ela mesma: a perspectiva africana na História Geral da África (UNESCO)
}

\author{
(versão corrigida) \\ O exemplar original se encontra disponível no CAPH da FFLCH (Centro de Apoio à \\ Pesquisa Histórica)
}

MURYATAN SANTANA BARBOSA

Tese apresentada ao Programa de Pós- Graduação em História Social do Departamento de História da Faculdade de Filosofia, Letras e Ciências Humanas da Universidade de São Paulo, para a obtenção do título de Doutor em História.

Orientadora: Profa. Dra. Marina de Mello e Souza

São Paulo 
Autorizo a reprodução total ou parcial deste trabalho, por qualquer meio convencional ou eletrônico, para fins de estudo e pesquisa, desde que citada a fonte.

Catalogação na Publicação

Serviço de Biblioteca e Documentação

Faculdade de Filosofia, Letras e Ciências Humanas da Universidade de São Paulo

Barbosa, Muryatan Santana
A238Á África por ela mesma: a perspectiva africana na História
Geral da África (UNESCO) / Muryatan Santana Barbosa ; orientadora
Marina de Mello e Souza. - São Paulo, 2012. $208 \mathrm{f}$.
Tese (Doutorado)- Faculdade de Filosofia, Letras e Ciências
Humanas da Universidade de São Paulo. Departamento de História. Área de
concentração: História Social.
1. Historiografia. 2. Eurocentrismo. 3. História da África. 4.
Metodologia da História. 5. UNESCO. I. Souza, Marina de Mello e, orient.
II. Título




\section{FOLHA DE APROVAÇÃO}

BARBOSA, Muryatan Santana. A África por ela mesma: a perspectiva africana na História Geral da África (UNESCO). Tese apresentada ao Programa de PósGraduação em História Social do Departamento de História da Faculdade de Filosofia, Letras e Ciências Humanas da Universidade de São Paulo, para a obtenção do título de Doutor em História.

\section{Aprovado em:}

Banca Examinadora

Profa. Dra. Instituição:

Julgamento: Assinatura:

Profa. Dra. Instituição:

Julgamento: Assinatura:

Profa. Dra. Instituição:

Julgamento: Assinatura:

Prof. Dr. Instituição:

Julgamento: Assinatura:

Prof. Dr. Instituição: Julgamento: Assinatura: 
À Sil, Téo, Faizone, Soca e Taco 


\section{AGRADECIMENTOS}

Agradeço especialmente a minha orientadora, a professora Marina de Mello e Souza. Em particular, por seu rigor acadêmico, confiança e abertura de espírito, que me permitiu desenvolver este trabalho. Muito obrigado.

Ao meu professor no Departamento de História da Universidade de Harvard, o historiador ganense Emmanuel Kwaku Akyeampong. Por seu profissionalismo e generosidade durante as pesquisas e as discussões que permearam o curso sobre Fontes, Metodologia e Temas na História da África (2010). Tais atividades me possibilitaram ampliar minha formação intelectual em História da África e ter acesso a uma vasta bibliografia internacional. Agradeço também aos colegas do referido curso.

Pela hospitalidade e companherismo nos E.U.A, a Demétrio G. C. Toledo, Márcio Macedo, Denise Hirao, Thomas Grimm e ao professor Anani Dzidzienyo, da Universidade de Brown.

Às professoras Leila M. G. Leite Hernandez e Maria Antonieta M. Antonacci, por suas valoras contribuições e apoio na banca de Qualificação desta tese. Ademais, pela amizade.

Ao professor Fernando Augusto de Albuquerque Mourão, por ter compartilhado comigo sua sabedoria e experiência pessoal no projeto da História Geral da África $(H G A)$.

Ao professor Valter Roberto Silvério e a todos da UNESCO-Brasil, que me convidaram para participar do projeto Brasil-África: histórias cruzadas. Este convite me obrigou a retomar a $H G A$ pormenorizadamente, para realizar a revisão crítica dos dois volumes do Livro Síntese da Coleção História Geral da África (UNESCO, 2012).

Aos colegas e amigos do Núcleo de África, Colonialidade e Cultura Política (NEACP-DH-USP) e da revista Sankofa: Flávio Thales R. Francisco, Irinéia M. Franco dos Santos, Eduardo Januário, Rodrigo F. Bonciani, Thiago C. Sapede e Maria Rosa D. Ribeiro. 
Ao professor Wilson do Nascimento Barbosa, pelas conversas em torno desta tese.

A Silvia Eri Hirao, pela paciência e companheirismo.

A todos que fizeram comentários, críticas e sugestões ao conteúdo essencial deste trabalho, que foi exposto em encontros, seminários e conferências, ao longo dos últimos três anos.

Ao CNPq que, com seu apoio institucional e financeiro, no Brasil e no Exterior, com a Bolsa Doutorado Sanduíche (SWE), me permitiu concretizar este trabalho. 
O cientista crítico é crítico principalmente em relação a si próprio, ao seu trabalho, que deve executar nos limites das suas atribuições. $O$ valor ideológico adquirido por sua obra não the vem de uma deliberada intenção, não é uma mensagem de que lhe reveste, um ingrediente que lhe acrescenta maliciosamente, mas decorre do fato de que todo o conhecimento possui por sua natureza essa característica. Se o que produz procede de uma consciência que se identifica pela raiz com o pensar das massas da comunidade, esse condicionamento se concretizará nos produtos que cria, independentemente de qualquer intencional destinação. $\mathrm{O}$ cientista crítico revela-se, neste particular, imensamente mais livre que seus colegas que trabalham conscientemente para as finalidades de camadas minoritárias da sociedade.

Àlvaro Vieira Pinto 


\title{
RESUMO
}

\author{
BARBOSA, M. S. A África por ela mesma: a perspectiva africana na História Geral \\ da África (UNESCO). 2012. 208 f. Tese (Doutorado) - Faculdade de Filosofia, Letras \\ e Ciências Humanas, Universidade de São Paulo, São Paulo.
}

Esta tese traz uma análise da perspectiva africana na coleção História Geral da África (UNESCO). Para isto, baseia-se no exame da história institucional do projeto que lhe originou e da escrita da história ali presente, em seus oito volumes. Tais considerações levaram a definição da perspectiva africana como uma perspectiva que privilegia os fatores internos ao continente, em oposição aos externos, na explicação histórica, científica, da África. Ademais, constatou-se que esta perspectiva se diversifica, na História Geral da África (HGA), em três abordagens complementares da história da África: a) regionalismo; b) difusionismo intra-africano; c) sujeito africano. A partir de tal investigação, reflete-se sobre algumas consequências teóricas e metodológicas que tal perspectiva africana traz para uma visão científica contemporânea e tendencialmente pós-eurocêntrica da história da África.

Palavras-Chave: Historiografia - Eurocentrismo - História da África - Metodologia da História - UNESCO 


\begin{abstract}
BARBOSA, M. S. Africa by itself: the african perspective in the collection General History of Africa (UNESCO). 2012. 208 f. Tese (Doutorado) - Faculdade de Filosofia, Letras e Ciências Humanas, Universidade de São Paulo, São Paulo.

This thesis presents an analysis of the African perspective in the project General History of Africa (UNESCO). It examines the institutional history of the project and the writing of history in this collection of eight volumes. Such considerations have led to the definition of the African perspective as a perspective that focuses on the internal factors of the continent, as opposed to external ones, in its scientific explanation of Africa history. In addition, this study concluded that this perspective unfolds into three complementary approaches of the General History of Africa (GHA): a) regionalism b) intra-African diffusionism c) African subject. This analysis provides the basis for a discussion on some theoretical and methodological outcomes that such an African perspective brings to a scientific view on the history of Africa that is contemporary and potentially post-Eurocentric.
\end{abstract}

Keywords: Historiography - Eurocentrism - History of Africa - Methodology of History - UNESCO 


\section{SUMÁRIO}

Introdução. 1

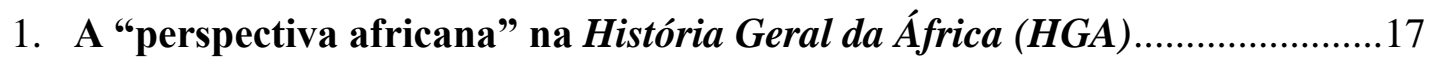

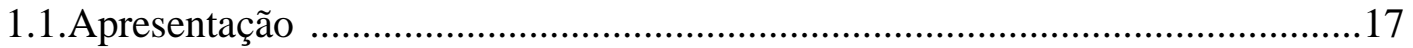

1.2. A "perspectiva africana" na história institucional do projeto $(H G A)$................19

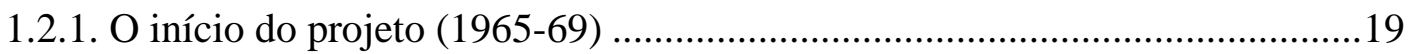

1.2.2. Organização e início da obra (1969-75) .......................................................21

1.2.3. Anos polêmicos (1975-78) ……..............................................................28

1.2.4. A vitória do pragmatismo (1978-82) …….....................................................33

1.3. A "perspectiva africana" na metodologia da $H G A$...........................................36

1.4. Definindo a "perspectiva africana" e suas abordagens ....................................45

2. $\mathrm{O}$ difusionismo intra-africano e a história da África da $\boldsymbol{H G A}$........................54

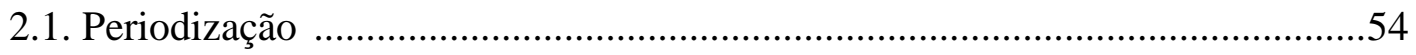

2.2. Neolítico e África Antiga (10 mil a. C. - VII d. C.) .........................................55

2.3. A África entre os séculos VII e XVII .........................................................70

2.4. A África entre os séculos XVII e fins do século XIX (1880)........................... 81

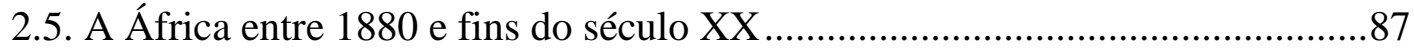

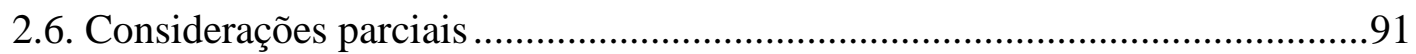

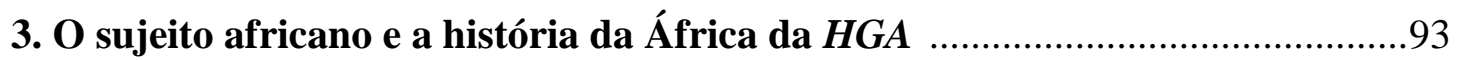

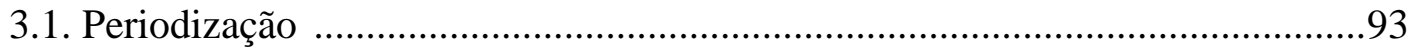

3.2. A experiência egípcio-faraônica (3.200 a. C - 332 a. C) .................................94

3.3. A civilização berbere-magrebiana (146 a. C - XIV d. C.) ..............................97

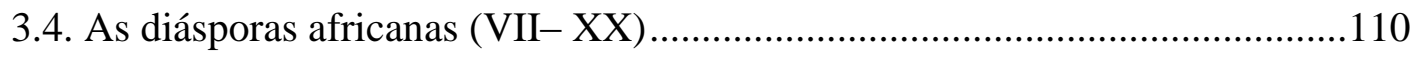

3.5. As resistências africanas contra o colonialismo e o neo-colonialismo (XIX-

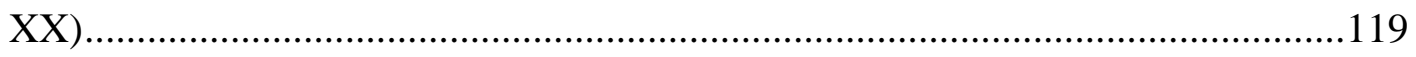

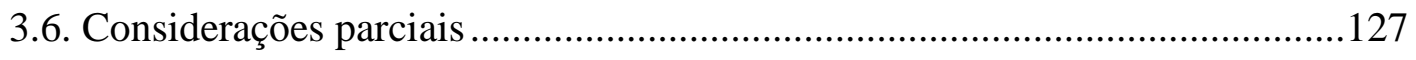




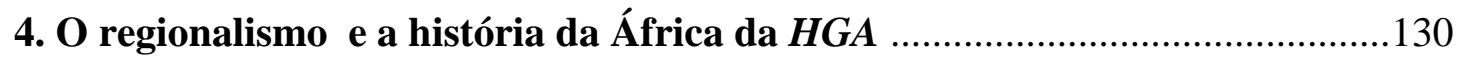

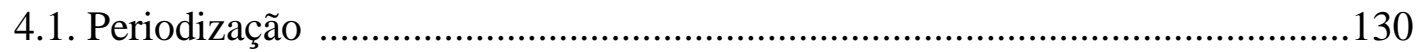

4.2. Neolítico e África Antiga (10 mil a. C. - XII d. C)......................................130

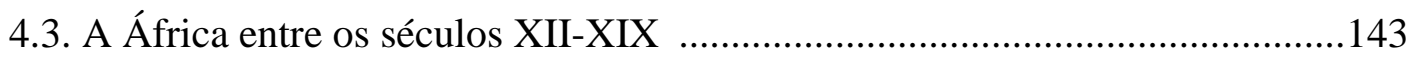

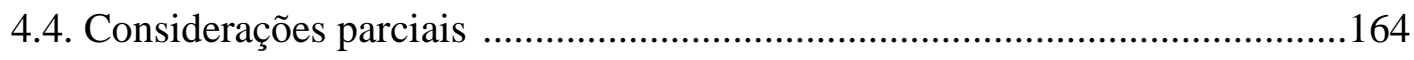

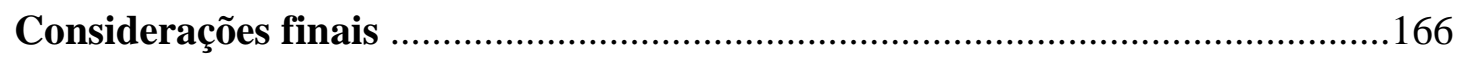

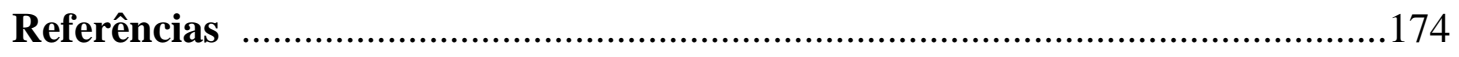

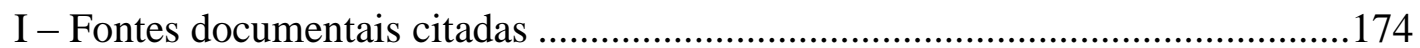

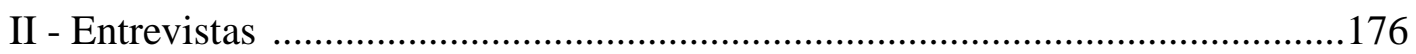

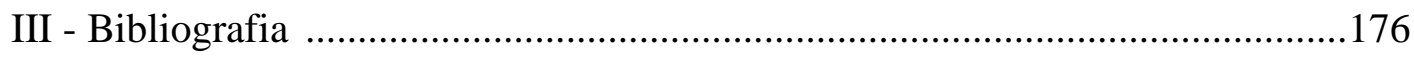




\section{LISTA DE FIGURAS}

Figura 1. A expansão banta 61

Figura 2. Hipóteses da origem dos Bantu e do inicio da metalurgia do ferro .63

Figura 3. Mapa do fluxo do ouro africano na economia muçulmana da África setentrional

Figura 4. Mapa da circulação de homens e técnicas na África Ocidental . .75

Figura 5: Grupos étnicos e movimentos populacionais na África Austral, entre 950 e 1000 .77

Figura 6. Mapa dos sítos e tradições arqueológicas mencionadas no texto .78

Figura 7: Mapa da expansao khoi-khoi .80

Figura 8. As províncias romanas da África do Norte no final do século IV da Era Cristã

Figura 9. A expansão do Estado Islâmico 105

Figura 10. O Magreb na primeira metade do século XI 107

Figura 11. A África, a Europa e a Ásia

Figura 12. O vale do Nilo e o Corredor Núbio

Figura 13. Mapa da África Central com a indicação das regiões de ocupação "neolitica" e da "Idade do Ferro Antiga"

Figura 14. Entidades políticas do Sahel entre os séculos XI e XVI

Figura 15. Algumas cidades e sítios mencionados no texto 148

Figura 16. Os diferentes grupos étnicos do Quênia e da Tanzânia 152

Figura 17. O Império Rozwi 157

Figura 18. A região dos Grandes Lagos, 1840-1884 160 


\section{Introdução}

A pesquisa e o ensino de história da África no Brasil passa por um momento de consolidação acadêmica e institucional. Vários são hoje os cursos e as disciplinas que difundem um conhecimento introdutório sobre o assunto. Estes, sem dúvida, trarão frutos positivos para a ciência histórica. E, mais importante, para o crescimento de uma visão anti-racista entre as novas gerações. Por este fato, inclusive, esta área tem ganhado muitos jovens adeptos.

É justamente neste momento, entretanto, que os estudos históricos sobre África necessitam estar atentos aos fundamentos críticos da sua prática teórica, para que esta energia renovadora não seja desencaminhada, seja por um ativismo anti-intelectual, seja por um academicismo formalizador, de viés positivista e eurocêntrico. Afinal, o que a disciplina História da África será num futuro próximo é consequência do que está sendo consolidado hoje, enquanto conhecimento histórico, compromisso político e institucionalização acadêmica.

Esta tese visa contribuir para uma necessária discussão epistemológica e teóricometodológica da história da África, tendo por foco a principal obra deste campo do conhecimento até hoje: a História Geral da África (HGA). Uma obra em oito volumes, com uma média de cerca de 900 páginas por volume, escrita por trezentos e cinquenta especialistas internacionais em história da África ${ }^{1}$. Vale dizer, não se trata de um ajuntamento de artigos, mas de um trabalho coletivo. Este, sob auspícios da UNESCO, durou cerca de trinta e cinco anos em sua primeira fase, entre 1965 e $1999^{2}$. Trata-se de

\footnotetext{
${ }^{1}$ Segundo informação da UNESCO. Disponível em http://www.unesco.org/new/pt/brasilia/specialthemes/ethnic-and-racial-relations-in-brazil/general-history-of-africa/. Acesso em 04 de Fev. de 2012.

${ }^{2}$ A primeira fase terminou com a publicação dos resumos da obra (em inglês, francês, árabe, suahili, peule e haussa) e dos oito volumes integrais em três línguas: inglês, francês e árabe. Parcialmente ela foi também publicada nos volumes originais em chinês, espanhol, japonês, suahili, peule, haussa, italiano e fulani. No Brasil, tinham sido publicados quatro volumes pela Editora Ática. A obra foi relançada em sua totalidade em 2010, pela parceria UNESCO-Ministério da Educação-UFSCAR. A partir de 2007 se iniciou a segunda etapa do projeto da $H G A$, intitulada "O uso pedagógico da História Geral da África". Aqui não se estuda esta fase. O objetivo desta é ampliar a difusão e a utilização pedagógica dos conhecimentos da $H G A$. Esta etapa foi idealizada, inicialmente, nos seguintes encontros organizados pela UNESCO: Dakar (1986), Nairobi (1989) e Tripoli (1999). A organização efetiva dela é resultado de um pedido formal da União Africana, que pretende adotar um currículo comum de História da África para os
} 
um trabalho que possibilitou um compêndio pormenorizado sobre o assunto, cobrindo toda a história da humanidade na África.

Existem hoje, pelo menos, quatro motivos primordiais para se revisitar a $H G A$. O primeiro deles é a qualidade científica da obra. Este fato foi resultante de um trabalho árduo e demorado de leituras e críticas. Na obra, cada artigo, escrito por um ou mais especialistas na área, era analisado e, muitas vezes, rescrito, antes de ser publicado. $\mathrm{O}$ segundo motivo é que este projeto da UNESCO garantiu que o ponto de vista dos intelectuais africanos sobre a história do seu continente, se tornasse algo internacionalmente relevante e acessível aos interessados. Com isto, desde então, não há mais justificativa para se fazer história da África, sem levar em consideração o que os intelectuais africanos pensam sobre o assunto. O terceiro motivo é de ordem local, pois a obra foi relançada no Brasil em 2010, com acesso livre pela internet. Algo que a tornará uma bibliografia básica para o conhecimento de história da África no país. O quarto motivo é objeto de estudo desta tese. Trata-se do fato de que a História Geral da África, apesar da inegável heterogeneidade de contribuições e autores, legou uma interpretação científica e potencialmente pós-eurocêntrica da história da África: $a$ "perspectiva africana".

O objetivo primordial desta tese é analisar o que é e qual a importância desta "perspectiva africana". Algo que passou despercebido à bibliografia internacional em história da África sobre a $H G A^{3}$. Para isto, pretende-se dar uma definição desta

seus países membros, baseado nas linhas estabelecidas pela $H G A$. Concomitantemente, em Outubro de 2011, na 36a . Conferência Geral da UNESCO, em Paris, decidiu-se pela preparação do nono volume da História Geral da África. O conteúdo deste novo volume ainda está em debate, mas, muito provavelmente, contará com uma seção dedicada as diásporas africanas.

\footnotetext{
${ }^{3}$ Salvo melhor juízo, não existe na bibliografia internacional uma análise como esta, que visa estudar a "perspectiva africana", conforme trazida pela $H G A$, como uma abordagem teórico-metodológica específica para a história da África. Este fato passa despercebido inclusive das resenhas escritas sobre os volumes da $H G A$.Provavelmente, a causa desta omissão é que tais resenhas não abarcam a totalidade da obra (oito volumes). Pelos menos, isto é o que se pode observar dos seguintes ensaios: Robert Ross. Trends in Historiography. Itinerario, Vol. VI, 2 (1982), pp. 149-153; J. H. Clarke. Ancient civilizations of Africa: the missing pages in world history. Journal of African Civilisations, 4, 2, (November, 1982), pp. 117-120; Bogumil Jewsiewicki \& P. L. Shinnie. The UNESCO History Project / L'Histoire-monument ou l'histoire conscience. Canadian Journal of African Studies, 15, 3 (1981), pp. 539-551; Michael Brett. UNESCO General History of Africa. Vol. II. Ancient Civilizations of Africa by G. Mokhtar. The Journal of African History, 23, 1(1982), pp. 117-120; David Phillipson. UNESCO General History of Africa. Vol. I. Methodology and African Prehistory by J. Ki-Zerbo. The Journal of African History, 23, 1(1982), pp. 115-117; Christopher Ehret \& J. J. Hoover. UNESCO General History of Africa, Vol. 1: Methodology and African Prehistory by J. Ki-Zerbo. African Studies Review, xxiv, 4 (1981), pp. 182-183; Ivor Wilks. Volume I: Methodology and African Prehistory by J. Ki-Zerbo and UNESCO General History of Africa. Volume II: Ancient Civilizations of Africa by G. Mohktar. International Journal of
} 
"perspectiva africana", comprovar a veracidade da mesma e delinear a linha investigativa que ela construiu para a história da África, tendo por foco a escrita da história na $H G A$.

Todavia, antes de adentrar na investigação referida, de viés internalista, cabe mostrar a originalidade do projeto coletivo da $H G A$, em sua inserção geral no campo historiográfico. Em particular, dos estudos historiográficos sobre a África. Por outro lado, tal contextualização visa qualificar o desafio intelectual da $H G A$, dentro de um escopo maior e mais atual, cujo cerne são as tentativas contemporâneas de construir um saber que supere as premissas e a agenda eurocêntrica, ainda reinantes nas ciências humanas. Dizer isto, entretanto, implica certas convicções acerca da relação entre eurocentrismo, pensamento social e razão histórica, que cabe qualificar.

\section{Eurocentrismo e História}

Existe hoje certo consenso nos debates acadêmicos sobre a necessidade de uma discussão das concepções eurocêntricas dominantes na ciência contemporânea ${ }^{4}$.

African Historical Studies, 15, 2, (1982), pp. 283-285; Richard Rathbone. The UNESCO General History of Africa, Vol. VIII: Africa since 1935 by Ali A. Mazrui. The International Journal of African Historical Studies, Vol. 28, No. 1 (1995), pp. 182-184; Phyllis M. Martin. The UNESCO General History of Africa, Volume VII: Africa under Colonial Domination 1880-1935 by A. Adu Boahen. The International Journal of African Historical Studies, Vol. 20, No. 2 (1987), pp. 351-353; John D. Hargreaves. UNESCO General History of Africa Vol. I: Methodology and African Prehistory by J. Ki-Zerbo. Africa: Journal of the International African Institute, Vol. 54, No. 3, Interventions of the State (1984), pp. 111-112; Jacques L. Hymans. The UNESCO General History of Africa. Volume VI: Africa in the Nineteenth Century until the 1880's by J. F. Ade Ajayi. African Studies Review, Vol. 34, No. 1 (Apr., 1991), pp. 140142; John Lamphbear. The UNESCO General History of Africa. Vol. 4. Africa from the XIIth to the XVIth Century by D. T. Niane. Research in African Literatures, Vol. 18, No. 1, Special Issue on Literature and Society (Spring, 1987), pp. 80-82; E. Ann McDougall. The sands of time. UNESCO General History of Africa, Volume VI: Africa in the Nineteenth Century Until the 1880 s by J. F. Ade Ajayi. The Journal of African History, Vol. 35, No. 2 (1994), pp. 314-316; Christopher Fyfe. UNESCO General History of Africa, Vol. VII, Africa under Colonial Domination, 1880-1935 by A. Adu Boahen. The Journal of African History, Vol. 27, No. 1 (1986), pp. 178-180; Wyatt MacGaffey. Who owns Ancient Egypt? The Journal of African History, Vol. 32, no. 3 (1991), pp. 515-519; J. Vasina Unesco and African historiography. History in Africa. Vol. 20, 1993, pp. 337-352.

\footnotetext{
${ }^{4}$ Ver, por exemplo, o relatório da Comissão Calouste Gulbenkian sobre a reestruturação das ciências sociais, publicado em WALLERSTEIN, Immanuel et al. Para abrir as ciências sociais. São Paulo: Cortez, 1996. Existe hoje farta literatura sobre o tema. Em relação às ciências humanas, o debate tem-se fundamentado em uma apropriação transdisciplinar de diferentes tradições críticas, enfatizando a cooperação Sul-Sul. Para isto, criam-se novos espaços institucionais de diálogo. E, alguns analistas contemporâneos, como Edgardo Lander (2000), Sandra Harding (2011), Boaventura de Souza Santos
} 
Todavia, apesar de sua amplitude, tal debate é algo recente. Basta lembrar que as contribuições pioneiras sobre o assunto datam da década de 1950 e início dos 1970, como aquelas dos sociólogos A. Guerreiro Ramos (Redução sociológica, 1958) e A. Abdel-Malek (A dialética social, 1972). Foi apenas com o célebre livro de Edward Said, Orientalismo (1978), que o tema tornou-se assunto candente internacionalmente.

Existem diversas formas de caracterizar o eurocentrismo. Por vezes, ele é visto como mero fenômeno etnocêntrico, comum aos povos de outras épocas históricas. Mas para a maioria dos autores que tratam atualmente da questão, o eurocentrismo deveria ser caracterizado, diferentemente, como um etnocentrismo singular, entendido como uma ideologia, paradigma e/ou discurso.

As diferenças que aí se colocam estão mais no plano interpretativo do que conceitual. Os autores que tratam o eurocentrismo como discurso visam analisá-lo, geralmente, em sua manifestação mais cotidiana, no senso comum popular, nos meios de comunicação de massa, nas instituições etc (Shohat \& Stam, 1997). Os autores que preferem enfatizá-lo como ideologia e/ou paradigma, tendem a focar, em seus estudos, o caráter eurocêntrico do pensamento erudito europeu-ocidental, em sua filosofia, teoria social etc (Young, 1990; Dussel, 1993; Quijano, 2000).

Nesta tese, tratar-se-á o eurocentrismo a partir da definição dada pelo economista Samir Amin. Este autor, em trabalho clássico sobre o tema (Eurocentrismo, 1994), o analisou como a ideologia do capitalismo como modo de produção realmente existente, cuja origem remontaria ao século XVI. É o período de início do colonialismo na América e da consolidação do Renascimento na Europa Ocidental. Para Amin, o núcleo essencial do eurocentrismo seria a crença generalizada de que o caminho do desenvolvimento europeu-ocidental fosse uma fatalidade desejável para todas as sociedades e nações. Tratar-se-ia, pois, de uma estrutura mental de caráter provinciano. Todavia, por sua aparência universalista e modernizadora, possuiria grande poder de difusão, para além da visão de mundo das classes dominantes europeias, que lhe deram origem.

(2004), Immanuel Wallerstein (2007), Walter Mignolo (2003), Nelson Maldonado-Torres; Mignolo \& F. Schiwy (2006) entre outros, vem buscando linhas de continuidade que solidifiquem tal produção intelectual. 
Limitando-se às consequências deste fenômeno para o pensamento histórico europeu-ocidental, é perceptível o quanto esta ideologia, assim entendida, esteve presente no pensamento dos grandes pensadores europeus, deturpando a percepção destes acerca dos demais povos do mundo. Tais povos eram vistos, então, na melhor das hipóteses, como crianças a serem educadas pelas luzes da Razão, em uma percepção provincialista que outorgava um "R" maiúsculo à razão histórica europeia-ocidental. Existe uma literatura recente que analisa de forma pormenorizada esta visão em autores clássicos da filosofia como Descartes (Quijano, 2000), Kant (Eze, 1997), Hegel (Dussel, 1993) e outros 5 .

O mesmo olhar pode ser identificado no pensamento social europeu dos séculos XVIII e XIX, de forma mais diversificada. Existe uma tendência eurocêntrica recorrente, por exemplo, nas Filosofias da História, a partir de autores clássicos como Voltaire, Vico, Condorcet, Hegel, Marx e Engels. É certo que existe uma heterogeneidade evidente no pensamento de tais autores. Entretanto, o que os une - e por isto são os principais fundadores da Teoria da História - são suas tentativas de, a partir da Filosofia, construir interpretações evolutivas das sociedades humanas, baseadas no progresso da história europeia-ocidental.

Além das Filosofias da História, teorias sociais do século XIX, como o evolucionismo de Spencer e o positivismo de Comte, podem ser considerados casos extremos deste provincialismo europeu, auto-declarado como universalista. Nestas perspectivas francamente eurocêntricas, as sociedades e os povos não europeus (tidos por "primitivos", "pré-modernos", “pré-lógicos", “arcaicos"), deveriam ser estudados como estágios de um caminho civilizacional único, cujo ápice seria a Europa Ocidental. Aí, na melhor das hipóteses, o passado destas sociedades deveria ser entendido como parte do germe deste processo evolutivo.

Assim, pois, se reproduziu a crença na excepcionalidade europeia, definida de formas diferenciadas. Seja por uma compreensão econômico-social (capitalismo ou industrialismo); culturalista (modernidade, espiritualidade medieval, cultura grecoromana); religiosa (cristã ou judaico-cristã); racial (branca ou ariana) etc. Trata-se, em

\footnotetext{
${ }^{5}$ Para mais detalhes ver, entre outros: Emmanuel C. Eze (Ed.). Race and the Enlightenment: A Reader. Wiley-Blackwell, 1997; Andrew Valls (Ed.). Race and Racism in Modern Philosophy. NY: Cornell University Press, 2005.
} 
ultima instância, de um problema ontológico recorrente, ainda não suficientemente examinado em sua importância científica e política.

Este eurocentrismo foi integralmente assimilado pelos historiadores que trabalharam pela institucionalização do campo historiográfico no século XIX, como, por exemplo, Jules Michelet e Leopold Von’Ranke. Os compêndios de "história universal" de ambos são etnocêntricos e teleológicos, narrando à história humana como um prelúdio da dominação europeia-ocidental.

Entretanto, nestes historiadores, mais do que em pensadores europeus anteriores citados, vê-se uma preocupação de narrar esta história mundial, ressaltando sua nação de origem - respectivamente França e Prússia - como representante máxima da especificidade evolutiva europeia. Seja por sua face "moderna", contratualista (Michelet); seja por sua face romântica, de origem místico-religiosa (Ranke). Trata-se de uma tendência também observável em outros historiadores do século XIX, como Thomas B. Macaulay, Treitschke, Fustel de Coulanges e outros (Fontana, 1998, pp. 117-120).

Neste sentido, a História disciplinar pode ser vista como um caso exemplar da crescente associação de interesses entre o Estado-Nação e a institucionalização das ciências humanas, na Europa Ocidental do século XIX. Aí naturalizado, o eurocentrismo renova-se na heterogeneidade do discurso teórico, dentro e fora da História. Algo que, sem dúvida, multiplica as explicações sobre a suposta superioridade europeia.

É certo que, em última instância, pode-se agrupar as razões que legitimavam tal superioridade nos grandes erros das macro-narrativas etnocêntricas, qualquer que seja sua origem. Jorn Rusen (2004, p. 122), por exemplo, analista historiográfico, sintetizou três dos erros fundamentais de todo etnocentrismo: a) distribuição assimétrica de valores negativos e positivos, de acordo com a referência de quem julga; b) visão teleológica da formação identitária; c) concepção espacial monocêntrica. Todavia, a variedade e multiplicidade das argumentações, assim como o poder social que possuem, são fatos que marcam a singularidade do etnocentrismo da ideologia eurocêntrica.

Assim sendo, uma questão torna-se pertinente. O que ocorre ao historiador ou filósofo social quando, olhando para o passado dos povos não europeus, não encontra 
ali a genealogia da modernidade europeia-ocidental? Trata-se de uma questão pertinente. Hegel, por exemplo, foi peremptório neste ponto, ao falar sobre o passado da África, que aqui interessa ressaltar. Diz o filósofo alemão que, ali, não havendo "progressos" e "movimentos históricos" não haveria, por conseguinte, "história mundial".

Por mais estranheza que esta assertiva traga hoje para uma visão politicamente correta da ciência, ela toca em premissas desconcertantes para o pensamento historiográfico de viés evolucionista do século XIX. Afinal, além da aparente falta de grandes "progressos" e "movimentos históricos", sobretudo na África sul-saariana, a realização de uma história da África engendra uma dificuldade em relação à sua relativa falta de fontes escritas, para sua reconstrução histórica. Esta é uma questão pertinente que, para existir como sub-área do conhecimento historiográfico, a História da África (entre outras) teve que responder.

\section{História da África e a descolonização da história}

A História da África como área disciplinar é fruto do Pós-Guerra ( $2^{\mathrm{a}}$. Guerra Mundial). Como tal, ela responde a certos dilemas teóricos e práticos que devem ser precisados.

Teoricamente, a História da África é fruto de um distanciamento gradual, mas decisivo, da historiografia do século $\mathrm{XX}$ em relação à historiografia tradicional de cunho político-diplomático, dominante no século XIX. Pode-se observar tal ensejo na obra de diversos historiadores da passagem do século XIX para o século XX, como, por exemplo, Fustel de Coulanges, Gustav Schmoller, Karl Lamprecht, James Robinson, Henri Berr e outros. Todavia, a ruptura com esta História tradicional só foi consolidada a partir dos anos 1930, com as contribuições clássicas da Escola dos Annales. Em texto conhecido, Peter Burke (1991) definiu esta "revolução" dos Annales na historiografia em três pontos centrais: a) a inter-disciplinaridade; b) a perspectiva totalizante; c) a história "problematizada". Em Marc Bloch, Apologia à Historia, Lucien Febvre, Combates pela Historia e Fernand Braudel, Historia e ciências sociais, vê-se o cerne desta nova proposta historiográfica. Também certo marxismo, nos primeiros decênios 
do século XX, teve uma contribuição importante para esta superação, como mostram os trabalhos históricos de K. Kautsky, V. Lenin, R. Luxemburgo, A. Gramsci, J. C. Mariátegui, N. Bukharin, Caio Prado Jr., e muitos outros. Estas tradições, com a especialização e ampliação do campo acadêmico, foram discutidas e reinterpretadas por historiadores de outros países e correntes de pensamento.

Hoje, são perceptíveis as razões teóricas que possibilitaram que esta renovação historiográfica tenha se difundido rapidamente pelo mundo, sob a tutela dos Annales e do marxismo, em contraposição à historiografia tradicional. Tal difusão, todavia, decorreu também de fatores extra-acadêmicos. Entre os vários que se poderia citar, cabe lembrar a importância simbólica que as duas Guerras Mundiais tiveram para a derrocada do otimismo europeu, acerca de sua própria sociedade e países. Não se tratava mais, tão somente, de vangloriar a Nação.

O nascimento disciplinar da História da África, sobretudo na França e na Inglaterra, foi uma consequência desta ampliação paradigmática da História tradicional, do século XIX. Como observa Alberto da Costa e Silva (1996), isto é perceptível, por exemplo, nas publicações especializadas sobre a história do continente, como o The Journal African History, na Inglaterra, e no Bulletin de l'Institut Français de l'Afrique Noire, na França. Assim como em livros importantes das décadas de 1950 e início dos 1960, que trouxeram um conhecimento introdutório sobre o assunto a um público mais amplo, como, por exemplo: a) A velha África redescoberta (1959), de Basil Davidson; b) História dos povos da África negra (1960), de Robert \& Marianne Cornevin; c) Breve história da África, de R. Oliver e J. Fage (1962); d) História da África Negra (1961), de Jean-Suret Canale; e) Nações negras e cultura (1955), de Cheikh Anta Diop; f) África, seus povos e sua história cultural (1959), de G. Murdock. Assim, a história da África nascia como uma consequência específica da consolidação de uma nova historiografia, sem a qual não haveria uma história da África a se produzir no mundo acadêmico.

Por outro lado, apesar do que foi aqui dito, seria um erro supor que, por serem eivados de eurocentrismo, a filosofia e a teoria social europeia dos séculos XVIII e XIX, em nada teriam contribuído para o desvelamento de realidades histórico-sociais não europeias. É certo que pouco se escreveu até o início do século XX, acerca da história de outros povos e civilizações. Há, entretanto, uma questão importante. Ao se 
expressarem como universalistas sendo, em verdade, provincialistas, os europeus ajudaram a criar um instrumental teórico pelo qual os demais povos poderiam, tendencialmente, re-significar a imagem de si próprios.

Assim, nos anos 1950, o arcabouço teórico ocidental foi importante na formação da primeira geração de historiadores africanos, quando estes começaram a construir uma história da África realizada pelos próprios africanos. Tratava-se, sobretudo, de depurar tais concepções de seu viés eurocêntrico. Para isto, dever-se-ia realizar uma adequação teórico-metodológica que visava qualificar tal saber, para embasar uma história científica da África. Isto, em oposição à visão colonialista sobre o continente. Este objetivo, no contexto linguístico de época, marcado pelas Independências Nacionais Africanas, foi chamado de "descolonização da história".

Um exemplo deste intento se encontra nos trabalhos do primeiro grande historiador africano da geração dos anos 1950 e 1960: o senegalês Cheikh Anta Diop. Em livros conhecidos como Nações negras e cultura (1955) e Anterioridade das civilizações africanas (1967), Diop trabalhou uma ideia presente no pensamento social do século XIX. Esta ideia era de que o Egito fora uma civilização negra; e que esta teria sido uma origem cultural do mundo helenístico (por consequência, greco-romano) e das sociedades africanas posteriores. Ao qualificar esta tese, de forma original, Diop perseguia um duplo objetivo. Primeiro, defender a africanidade do Egito Faraônico e do mundo mediterrânico antigo, de onde surgiram a maior parte das civilizações indoeuropeias. Em segundo lugar, apoiar o princípio da unidade cultural africana, de origem nilótica. Esta possuiria as seguintes características primordiais: estrutura matriarcal, expressão dionisíaca da vida, idealismo religioso, coletivismo e otimismo (Diouf \& Mbodj, 1992; Barbosa, 2009).

Por outro lado, o historiador Boubacar Barry (2000), aponta duas obras sobre a tradição oral africana, entre fins dos anos 1950 e início dos 1960, que, sob o signo da descolonização, também teriam marcado este período inicial dos estudos africanos sobre a África: a) Campanhas do Senegal (1958), de Abdoulaye Ly; b) Sudjata ou o épico mandinga (1960), de Djibril Tamsir Niane. Vale lembrar também do livro A tradição oral (1958), de Jan Vansina. Afinal, este seria de grande valia metodológica para os estudos africanos posteriores, que trabalharam com a história oral dos povos do continente. 
Os anos 1950 são também o período áureo da Sociedade Africana de Cultura ${ }^{6}$ e da revista Présence Africaine ${ }^{7}$, principal órgão de divulgação do pensamento da intelectualidade africana e afro-descendente do pós-Guerra. Estas organizações fortaleciam um elo diaspórico do negro, em que os intelectuais africanos e afrodescendentes se colocam como co-partícipes de uma mesma comunidade de interesses, na luta contra o racismo e o colonialismo. Os dois congressos de Escritores e Artistas Negros à época, em Paris (1956) e Roma (1959) são uma concretização deste ideal.

Ao longo das décadas de 1950 e 1960, nasceram também os primeiros centros universitários no continente africano, que davam especial interesse à História na África em seus currículos, como a Universidade de Dakar (Senegal); o Gordon College de Cartum (Sudão); o Makerere College de Kampala (Uganda); a Universidade de Ibadan (Nigéria); a Universidade de Lovanium (Congo, posteriormente Zaire); a Universidade de Dar-Es-Salam (Tanzânia); Universidade de Nairobi (Quênia) (Fage, 2010, pp. 2021). Nestes institutos, professores europeus se tornaram os primeiros docentes contratados para ensinar a temática, como J. D. Fage em Gana; J. D. Hargreaves, em Serra Leoa; C. Wrigley e C. Ehrlich, na Nigéria; J. Vansina, no Congo e em Ruanda, R.

\footnotetext{
${ }^{6}$ A Sociedade Africana de Cultura foi criada por ocasião do Primeiro Congresso dos Escritores e Artistas Negros, em Paris (1956). Era sua missão defender os interesses das nações africanas e o enriquecimento da solidariedade internacional do povo negro. Em 1958, tornou-se órgão consultivo da UNESCO. Seu primeiro evento foi o Segundo Congresso de Escritores e Artistas Negros, em Roma, em 1959. A partir de então, a revista Presencé Africaine tornou-se parte integrante da organização.
}

${ }^{7}$ Principal revista do mundo negro-africano no século XX. Seu idealizador e principal diretor foi o intelectual senegalês Alioune Diop (1910-1980). O primeiro número da revista foi lançado em 1947, com o apoio de importantes nomes da intelectualidade europeia, como Jean Paul-Sartre, André Gide, Albert Camus, Théodore Monod, Georges Padmore, Roger Bastide e outros. Seu intuito era a defesa do pensamento e das civilizações negro-africanas. Um de seus principais eventos foi a organização do Primeiro Congresso de Escritores e Artistas Negros, em Paris, em 1956. No Congresso de Paris, estiveram presentes os seguintes intelectuais, conforme seus países de origem à época: G. Sekoto (África do Sul), P. Tchibamba (África Equatorial Francesa), Mario P. Andrade, M. Lima (Angola), P. Blackman, G.Lamming (Barbados), Tibério (Brasil), Pasteur T. Ekollo, François Sengat Kuo, Benjamin Matip, Nyunaï, F. Oyono (Camarões), A.R. Bolamba (Congo Belga), Bernard Dadié (Costa do Marfim), W. Carbonel (Cuba), N. Damz, Paulin Joachim, P. Hazoumé (Dahomei), H.M. Bond, M. Cook, J.A. Davis, W., J. Ivy Fontaine, Richard Wright (Estados Unidos da América), P. Mathieu, Moune de Rivel (Ilhas Guadalupe), J. Alexis, R.P. Bisanthe, René Depestre, A. Mangones, E.C. Paul, R. Piquion, J. Price-Mars, E. Saint-Lot (Haiti), Cédric Dover (Índia), M. James, J. Holness (Jamaica), Andriantsilaniarivo, Jacques Rabemanjara, F.Ranaivo (Madagascar), L. Achille, Aimé Césaire, Frantz Fanon, Edouard Glissant (Martinica), M. Dos Santos (Moçambique), B. Hama (Niger), B. Enwonwu, L. A. Fabunmi, M. Lasebikan, J. Vaughan (Nigéria), Mamadou Dia, C.A. Diop, David Diop, Diop O. Socé, A. Seck, L.S. Senghor, Bachir Touré, Abdoulaye Wade (Sénégal), D. Nicol (Sierra Leoa), Hampaté Bâ, A. Wahal (Sudão), F. Agblemagnon (Togo). Disponível em: http://portal.unesco.org/fr/ev.php. Acesso em: 09 de Abrilde2009. 
Mauny e Y. Person, no Senegal. Entre estes havia geralmente simpatia pelas Independências Nacionais Africanas (Curtin, 2010, pp. 50-54).

É certo que a formação intelectual dos jovens estudantes africanos nestas e outras universidades e instituições fora da África ${ }^{8}$, assim como o ensino dirigido por professores europeus e estadunidenses no próprio continente, foi um fato condicionante do tipo de prática profissional, que se estabeleceu entre os historiadores africanos, a partir da década de 1970. Todavia, o intento de descolonizar a História para projetar uma "verdadeira" História da África, científica, segue sendo um objetivo desta geração de historiadores africanos do pós-Guerra. Como afirma Barry (2000, p. 52), este intento marca a realização de encontros regulares, como o Congresso de Africanistas de 1961, o Congresso Internacional sobre a História da África, em 1965, na Tanzânia (também conhecido como o Encontro de Dar-Es-Salam), e o de Yaundé, em Camarões, em 1975.

Esta difusão de interesse pela História da África promoveu uma maior quantidade e qualidade na produção historiográfica sobre o continente, que possibilitou o aumento do conhecimento acerca da temática, entre os anos 1960 e 1970 . Em 1975,

\footnotetext{
${ }^{8}$ Entre as primeiras a lecionar ou pesquisar o tema, entre as décadas de 1960 e 70: Universidade de Londres (Inglaterra), Escola de Estudos Orientais e Africanos (Inglaterra), Sorbonne (França), Centro de Estudos Africanos (França), Escola Prática de Altos Estudos (França), Universidade de Howard (EUA), Universidade de Yale (EUA), Associação de Estudos Africanos (EUA), Instituto Etnográfico de Leningrado (URSS), Universidade Patrice Lumumba (URSS) (Curtin, 2010, pp. 50-54).
}

${ }^{9} \mathrm{Em}$ uma lista discutível, pode-se citar, entre outros, os estudos de Joseph Ki-Zerbo. História da África Negra (1972); Basil Davidson. A África na História (1975) e A velha África redescoberta (1977); Endre Sik. A História da África Negra (1976); A. Akinjogbin. Daomey e seus vizinhos: 1708-1818 (1967); P. L. Shinnie. Meroé: uma civilização do Sudão (1967); J. S. Trimingham. O Islã na África Oriental (1964); Terence Ranger. Revoltas na Rodésia do Sul: um estudo da resistência africana (1967); C. S. Nicholls. A costa swahili (1971); K. O. Dike. Comércio e política no Delta do Níger, 1830-1885 (1959); Walter Rodney. Como a Europa subdesenvolveu a África (1972) e A História da Costa Superior da Guiné: 1545-1800 (1970); C. Meilassoux. Escravidão na África pré-colonial (1975); Daniel Mc Call. A África em perspectiva temporal (1964); Y. Person. Samori (1968); B. A. Ogot. Zamani (1968) e A história dos povos Luo do Sul (1967); T. Hopkins. História econômica da África Ocidental (1973); J. F. Ajayi; I. Espie \& K. O. Dike. Mil anos de história da África Ocidental (1969); J. F. Ajayi \& K. O. Dike. Missões cristãs na Nigéria (1965); R. C. Law. O Império de Oyo, 1600-1836 (1977); J. Fage (ed.). História da África - Cambridge. Vol. 2 (1978); R. Oliver (ed.). História da África-Cambridge. Vol. 3. (1977); R. Gray (ed.). História da África - Cambridge. Vol. 4 (1978); J. Flint (ed.). História da África - Cambridge. Vol. 5 (1976); J. Fage (ed.). História da África-Cambridge. Vol. 2 (1978); R. Oliver (ed.). História da África-Cambridge. Vol. 3. (1977); R. Gray (ed.). História da África-Cambridge. Vol. 4 (1975); J. Flint (ed.). História da África - Cambridge. Vol. 5 (1976); J. D. Clark. Pré-historia da África (1970); R. Hull. Cidades africanas antes da conquista europeia (1976); Jan Vansina. Reinos da Savana (1966); Boubacar Barry. O Reino do Wallo (1970); Philip Curtin. O trafico escravista no Atlântico (1970) e Mudanças econômicas na África Pré-colonial (1975); Joseph Greenberg. As línguas da África (1970); G. Connah. A arqueologia do Benim (1975); D. W. Phillipson. A pré-história tardia no Nordeste e Sudeste da África (1977); W. Y. Adams. Núbia: corredor da África (1977); Joseph Miller. Poder político e parentesco(1974); T. Shaw. Igbo-Ukwu (1970); A. Hampaté Bã.O Império Peul de Macina (1955) e Aspectos da civilização africana (1972); N. Levitzon. Antiga Gana e Mali (1973); Henri Brunschwig. 
foi publicado o primeiro $^{10}$ dos oito volumes da Cambridge History of Africa. Paralelamente, entre 1965 e 1999, com a participação de mais de trezentos especialistas em África, africanos e não africanos (sobretudo europeus e estadunidenses), a UNESCO organizou e promoveu a publicação da ambiciosa História Geral da África, um ponto de virada nos estudos sobre a história africana. Seus oito volumes, com cerca de 8.000 páginas, tornar-se-iam fonte obrigatória sobre o assunto.

A partir da década de 1980, com a ampliação ainda maior deste campo de estudos, vê-se uma multiplicação de estudiosos, temas e métodos de trabalho. Isto formou a História da África uma área disciplinar consolidada e internacionalmente reconhecida. Desde então, como observa Henk Wesseling (1992, p. 111), o que se constata nesta historiografia é que, por suas características próprias - sobretudo pelo fato de suas fontes escritas serem em sua maioria exógenas -, a História da África tende a seguir em muito as características atribuídas a Escola dos Annales e a nouvelle histoire: uma história interdisciplinar, problematizada e totalizante. Afinal, para reconstruir o passado africano era preciso aprender a reconstruir o passado de outras formas. E, estas formas, não se restringem à África.

Tratou-se aí tanto de um avanço intelectual, quanto institucional, com a formação de novas áreas de estudos historiográficos africanos, dentro e fora deste continente. O objetivo deste trabalho é focar o marco fundamental desta transformação: o projeto $H G A$.

\section{O projeto História Geral da África}

A ideia de uma História Geral da África teve sua origem no $1^{\circ}$. Congresso Internacional dos Africanistas, realizado em Acra, capital de Gana, entre 11 e 18 de Dezembro de 1962. Tratou-se de um grande evento que, com o suporte da UNESCO,

Partilha da África negra (1971); M. Mandami. Política e formação de classe em Uganda (1976); Y. M. Kobishchanov. Axum (1979); Samir Amin. Neo-colonialismo na África Ocidental (1975) e $O$ desenvolvimento desigual: ensaio sobre as formações sociais do capitalismo periférico (1975); K. Y. Daaku. Trocas comerciais e política na Costa do Ouro (1970); Ali Mazrui. Por uma pax africana (1967); M. Crowder. A África Ocidental sob domínio colonial (1968) e, como editor, A resistência na África Ocidental (1971); e muitos outros autores e textos. Títulos traduzidos em livre acepção.

${ }^{10}$ R. Gray (ed.). Cambridge History of Africa: from c. 1600 to c. 1790. Vol. 4 (1975) 
reuniu cerca de quinhentos especialistas em África de todo o mundo. Ou melhor, a ideia do projeto era provavelmente anterior. Todavia, ali se ratificou, de forma pública, o desejo de construir, com a ajuda da UNESCO, um trabalho de cooperação científica internacional, visando desenvolver a pesquisa histórica em África (UNESCO, 1966a, pp. 1-2). Em 1963, a ideia do projeto foi retomada na reunião de fundação da Organização da Unidade Africana (Vansina, 1993, p. 337). No ano seguinte, em 1964, ela foi encaminhada e aprovada como um dos projetos de cooperação científica internacional da $16^{\mathrm{a}}$. Conferência Geral da UNESCO. Desde então, portanto, se iniciou o projeto História Geral da África, propriamente dito.

Desde seu início, havia duas razões que justificavam a participação da UNESCO no projeto da $H G A$. Em primeiro lugar, tal instituição já estava à época voltada para a intensificação do seu trabalho na África. Isso é evidente, por exemplo, nas deliberações da 15a . Conferência Geral da UNESCO, em 1960, por mais esforços pela educação no continente. O apoio da UNESCO ao referido Congresso dos Africanistas fazia parte deste objetivo maior. Este, por sua vez, era um direcionamento que respondia à integração de uma grande quantidade de países africanos nos seus quadros. Sobretudo os recém-independentes, no início de 1960. Basta lembrar que, em 1960, existiam apenas nove países africanos na UNESCO; enquanto que, em 1963, este número já havia subido para trinta e dois. A outra razão é que a UNESCO poderia dar o respaldo institucional e financeiro que o projeto exigia. Afinal, desde seu início ele foi pensado como um trabalho científico internacional de grande envergadura.

Três motivos principais justificavam a criação do projeto da $H G A$, segundo seus idealizadores. Em primeiro lugar, havia o perigo de que as fontes para a história da África se perdessem definitivamente, tanto as fontes escritas, quanto as orais. E tal fato poderia ser revertido, em parte, com a coleta de fontes e organização dos arquivos em África. Eles poderiam acomodar a documentação existente, e aquela que ainda estar-seia por investigar. Mas isto deveria ser feito rapidamente. Em segundo lugar, havia o desejo de que $H G A$ pudesse sintetizar o conhecimento sobre o continente, ainda disperso e mal distribuído no tempo e espaço. Só assim se teria clareza das lacunas a serem pesquisadas. Por fim, havia o desejo de que a $H G A$ pudesse impulsionar uma escrita da história que superasse os preconceitos colonialistas sobre o continente, trabalhando para mostrar as contribuições africanas para a civilização em geral. Algo 
visto como sumamente necessário às nações africanas, no período pós-colonial, que se instaurava na África (UNESCO, 1966a, p.1).

Ao tornar-se o orgão gestor da $H G A$, em 1964, a UNESCO assumia o apoio institucional, administrativo e financeiro do projeto. Na prática, entretanto, como veremos, ele foi construído de forma autônoma, por uma comissão de especialistas de notório saber sobre a temática.

Os pontos primordiais do projeto da $H G A$ são firmados na Apresentação do projeto, de 1979, assinada pelo então presidente do Comitê, o historiador Betwhell Ogot.

1) Em que pese visar a melhor qualidade científica possível, a História Geral da África não busca a exaustão e se pretende uma obra de síntese que evitará o dogmatismo. Sob muitos aspectos, ela constitui uma exposição de problemas indicadores do estádio atual dos conhecimentos e das grandes correntes de pensamento e pesquisa, não hesitando em assinalar, em tais circunstâncias, as divergências de opinião. Ela assim preparará o caminho para posteriores publicações.

2) A África aqui é considerada com um todo. O objetivo é mostrar as relações históricas entre as diferentes partes do continente, muito amiúde subdividido, nas obras publicadas até o momento. Os laços históricos da África com os demais continentes recebem a atenção merecida, e são analisados no âmbito dos intercâmbios mútuos e das influências multilaterais, de forma a fazer ressurgir, oportunamente, a contribuição da África para o desenvolvimento da humanidade.

3) A História Geral da África consiste, antes de tudo, uma história de ideias e de civilizações, das sociedades e das instituições. Ela fundamenta-se sobre uma grande diversidade de fontes, aqui compreendidas a tradição oral e a expressão artística.

4) A História Geral da África é aqui essencialmente examinada desde seu interior. Obra erudita, ela também é, em larga medida, o fiel reflexo da maneira através da qual os autores africanos veem sua própria civilização. Embora elaborada em âmbito internacional e recorrendo a todos os dados científicos atuais, a História será igualmente um elemento capital para o reconhecimento do patrimônio cultural africano, evidenciando os fatores que contribuem para a unidade do continente. Esse esforço em examinar os fatos a partir de seu interior constitui o ineditismo da obra e poderá, além de suas qualidades científicas, conferir-lhe um grande valor de atualidade. Ao evidenciar a verdadeira face da África, a História poderia, em uma época dominada por rivalidades econômicas e técnicas, propor uma concepção particular dos valores humanos (B. Ogot, 2010a, p. XXVII) 
Esta tese visa analisar este último ponto da $H G A$. Isto, tanto na problematização de sua significação teórica, quanto nas consequências daí derivadas, para a construção da história da África, nos oito volumes da obra. O que aqui se chama de "perspectiva africana" da $H G A$ é um tipo de interpretação historiográfica derivada de uma análise deste último ponto. Para tanto, faz-se necessário explicar a ordem de exposição e os procedimentos metodológicos que guiam este trabalho.

\section{Metodologia}

Para embasar tal análise da $H G A$, esta tese seguirá a seguinte divisão. No primeiro capítulo tratar-se-á de problematizar esta "perspectiva africana" da obra, levantada na Apresentação de B. Ogot. Para isto seguir-se-á dois caminhos. Inicialmente, se buscará as origens e a importância deste ideal da "perspectiva africana" na organização e construção do projeto, entre 1965-79; período crucial de realização da obra. Posteriormente, apresentar-se-á a definição desta "perspectiva africana", que servirá de base para a análise subseqüente da escrita da história da África na $H G A$.

Os demais capítulos (2, 3 e 4) desta tese analisarão, de forma imanente e pormenorizada, como esta "perspectiva africana" pode ser encontrada em três abordagens diferentes da história da África, na $H G A$ : a) difusionismo intra-africano; b) sujeito africano; c) regionalismo. A ordem desta exposição, nos próximos capítulos, está construída conforme o espaço ocupado por cada uma destas abordagens dentro da própria $H G A$. Por isto, a análise, no segundo capítulo, se inicia com o difusionismo intra-africano. Posteriormente, no terceiro capítulo, analisar-se-á o tipo de história da África derivado do sujeito africano, e, finalmente, no quarto capítulo, o regionalismo.

Por fim, se farão algumas considerações finais sobre a temática, analisando as continuidades e descontinuidades trazidas por estas abordagens, enquanto produtos da "perspectiva africana”, assim como certas consequências teórico-metodológicas de sua utilização. 
A metodologia para realizar esta pesquisa é de caráter holístico ${ }^{11}$ e empírico ${ }^{12}$. Ela não se funda em esquemas pré-concebidos de análise das ideias, seja da história intelectual, seja da história das ideias. Ela se baseia nos problemas, objetivos, fontes, dilemas trazidos pela própria $H G A$. É, portanto, a partir da própria obra que se busca entendê-la. Sobretudo, em relação ao desafio proposto pelos organizadores desta, em desenvolver uma "perspectiva africana" para a interpretação da história da África: a África por ela mesma.

Isso não implica que este estudo esteja desligado da bibliografia e das preocupações contemporâneas do conhecimento humanístico, especialmente historiográfico. Pelo contrário. Ao se revisitar a $H G A$, neste trabalho, busca-se fazê-lo de modo a atualizar sua herança crítica. Em especial, por sua proposta de criar uma "perspectiva africana" para a história da África. Algo que se vê como pertinente ao desafio contemporâneo de formulação de saberes tendencialmente pós-eurocêntricos, sobre a realidade histórico-social. Neste sentido, é importante deixar evidente que não se pretende aqui revisitar a $H G A$ enquanto testemunho de sua época. Ela interessa aqui como produtora de uma criação cultural vista como atual, que cabe qualificar.

Neste particular, esta pesquisa da $H G A$ se inspira nas análises das ações culturais como práxis, estabelecidas, por exemplo, pelo filósofo tcheco Karel Kosik em Dialética do Concreto (2010, primeira edição: 1963). Neste livro, Kosik diferencia duas historicidades das obras culturais. A primeira seria sua existência como "fonte documental", entendida como "reflexo" ou "testemunho" de sua época. A segunda seria a historicidade das ideias como parte da práxis humana. Neste viés, caberia estudá-las na medida em que seus conteúdos são transmitidos a alguém, passando a existir, pela práxis, como produtoras de realidade histórico-social. Esta segunda análise é a que nós interessa. Afinal, trata-se de pensar a atualidade potencialmente pós-eurocêntrica de uma proposta teórico-metodológica da $H G A$ : a "perspectiva africana".

\footnotetext{
${ }^{11}$ Definição: "Qualquer doutrina que destaque a prioridade de um todo sobre suas partes" (Simon Blackburn, 1997, p. 185). Neste caso, o todo é a $H G A$.

${ }^{12}$ Definição: "Em sentido lato, uma crença empírica é uma crença que pode ser confirmada ou desmentida pela experiência sensível. Em sentido mais restrito, o termo pode ser limitado de maneira a que a confirmação tenha de evitar o uso de uma teoria intermediária, caso em que a crença se torna teórica e não empírica" (Simon Blackburn, p. 115). Utiliza-se aqui este sentido mais restrito.
} 
Dito isto, cabe agora esmiuçar o que seria, por fim, esta "perspectiva africana". Para isto, entretanto, buscar-se-á seguir a ordem da pesquisa, mostrando como a definição deste conceito se apresentou ao investigador. Posteriormente, no pormenor, apresentar-se-á quais as consequências deste fato para a história da África daí resultante. 


\title{
Capítulo1: A perspectiva africana na História Geral da África
}

\subsection{Apresentação}

A primeira definição da "perspectiva africana" trazida pelas fontes desta investigação é aquela da Apresentação do projeto (1979), assinada pelo historiador Bethwell Ogot, então presidente do Comitê Científico Internacional para a Redação de uma História Geral da África. Relembrando:

\begin{abstract}
A História Geral da África é aqui essencialmente examinada desde seu interior. Obra erudita, ela também é, em larga medida, o fiel reflexo da maneira através da qual os autores africanos veem sua própria civilização. Embora elaborada em âmbito internacional e recorrendo a todos os dados científicos atuais, a História será igualmente um elemento capital para o reconhecimento do patrimônio cultural africano, evidenciando os fatores que contribuem para a unidade do continente. Esse esforço em examinar os fatos a partir de seu interior constitui o ineditismo da obra e poderá, além de suas qualidades científicas, conferir-lhe um grande valor de atualidade. Ao evidenciar a verdadeira face da África, a História poderia, em uma época dominada por rivalidades econômicas e técnicas, propor uma concepção particular dos valores humanos (B. Ogot, 2010a, p. XXVII)
\end{abstract}

Pode-se destacar aí alguns elementos centrais. Tratar-se-ia de uma história essencialmente examinada a partir do seu interior. Mas ela seria também, "em larga medida", o fiel reflexo do modo como os autores africanos veem sua própria civilização. Ademais, seria uma história científica, uma história que buscasse o reconhecimento do patrimônio cultural africano e que buscasse os fatores que contribuem para a unidade do continente. Por fim, traria uma concepção particular dos valores humanos.

Sem dúvida, são muitos elementos para uma perspectiva histórica. Por outro lado, são pontos que merecem uma problematização. O mais polêmico é a afirmação de 
que a história ali delineada deveria ser "em larga medida, o fiel reflexo da maneira através da qual os autores africanos veem sua própria civilização". A questionabilidade da definição fica evidente com a utilização da expressão "em larga medida". Ela já revela as dificuldades de se postular uma conceituação não problemática da "perspectiva africana" para a história da África, que os organizadores da HGA buscavam construir.

Não resta dúvida que se pretendia, com a $H G A$, dar publicidade a opinião dos intelectuais africanos sobre sua própria história. Como dito, inclusive, consideramos este um legado fundamental da obra. No entanto, a HGA não foi uma obra organizada e escrita apenas pelos intelectuais africanos. De fato, eles foram a maioria nos conselhos diretivos do projeto. Entrementes, o trabalho contou com a participação de trezentos e cinquenta especialistas internacionais, em sua maioria não africanos. Do mesmo modo, a organização e efetiva realização da obra deveu muito, também, à presença ativa de intelectuais não africanos. Em especial, cinco deles: M. Gléglé, J. Devisse, J. Vansina, I. Hrbek e J. Vercoutter. Sobretudo por estas razões, é difícil imaginar que uma visão da "perspectiva africana" nestes termos, enquanto "o fiel reflexo do modo como os autores africanos veem a sua civilização", pudesse ter-se tornado dominante na obra, quanto mais exclusiva.

Diante deste fato, dois posicionamentos são possíveis. O primeiro poderia ser o de mostrar como este intento primeiro de construir uma "perspectiva africana" para a história da África teria sido desvirtuado na realização da obra. O segundo é analisar como esta "perspectiva africana" sempre foi um postulado problemático para os organizadores e participantes do projeto $(H G A)$. Como veremos a partir da leitura de fontes primárias (especialmente as atas das reuniões de organização do projeto) e da própria escrita da história na $H G A$, deve-se concluir que a segunda interpretação é a mais verossímil.

Nesse sentido, este primeiro capítulo, apresenta uma investigação da construção e do significado desta "perspectiva africana", em dois momentos. Primeiramente, trata da história institucional do projeto. Em segundo lugar, analisa a apresentação e debate metodológico da $H G A$, que perfaz a primeira parte do Volume I da obra (Metodologia e pré-história da África). Por fim, traz uma definição desta "perspectiva africana", conforme ela será analisada nos demais capítulos desta tese. 


\subsection{A "perspectiva africana" na história institucional do projeto $(H G A)$}

\subsubsection{O início do projeto (1965-69)}

Como dito, a História Geral da África foi iniciada em 1964, quando foi aprovada como um dos projetos de cooperação científica internacional da $16^{\mathbf{a}}$ Conferência Geral da UNESCO.

Para iniciar o projeto, o então Diretor Geral da UNESCO, o francês René Maheu, apontou o primeiro Diretor Científico da HGA. Foi escolhido para o cargo um dos primeiros historiadores acadêmicos africanos: o nigeriano Kenneth Onwuka Dike; vice-reitor da Universidade de Ibadan e presidente do $1^{\circ}$. Congresso Internacional dos Africanistas (1962). Foi sob orientação de K. O. Dike, portanto, que foram indicados os primeiros organizadores do projeto (UNESCO, 1966a, p.3).

A primeira reunião dos especialistas indicados pela UNESCO foi realizada em Abidjan, Costa do Marfim, entre Agosto e Setembro de 1966. Ali se formou o primeiro grupo organizador da $H G A$, intitulado Comissão de Especialistas para uma História Geral da África. O presidente desta Comissão foi K. O. Dike. O historiador Joseph KiZerbo (Alto Volta $^{13}$ ) foi o vice-presidente da mesma, e o historiador M. Lacheraf (Argélia), o secretário executivo. Fizeram parte desta reunião os seguintes pesquisadores, sem cargos específicos, J. F. Ade Ajayi (Nigéria), M. Dagnogo (Costa do Marfim), J. Devisse (França), H. E. M. El Fasi (Marrocos), H. E. A. Hampaté Bã (Mali), H. Djait (Tunísia), D. Mc Call (EUA), A. N’Daw (Senegal), D. T. Niane (Senegal), L. Yabloshkov (URSS). O Diretor Geral da UNESCO foi representado por N. Bammate, da Divisão de Estudos Culturais da UNESCO (UNESCO, 1966b, pp. 1-2).

Existem dois relatórios públicos sobre a reunião de Abidjan, de 1966, que são importantes para compreender as motivações e os objetivos dos primeiros organizadores da HGA: UNESCO-CLT-HGINAF-ABIDJAN-3 e UNESCO-SHC-2. São relatórios similares, mas não idênticos. Apenas o primeiro possui autoria, tendo sido redigido pelos professores Lacheraf, Ajayi, Mc Call, Niane, Devisse e Yabloshkov.

\footnotetext{
${ }^{13}$ Como praxe, escolheu-se indicar os nomes dos países conforme à época em que são citados.
} 
Estes relatórios confirmam que, em relação à pesquisa histórica, a $H G A$ foi um projeto justificado por três princípios básicos: a) organização de fontes; b) síntese do conhecimento existente; c) construção de uma nova história da África. O que a reunião de Abidjan fez foi concretizar uma agenda para a $H G A$ com ordem de prioridade, indo daqueles trabalhos mais urgentes para os demais, de longo prazo.

Neste sentido, o resultado mais importante desta reunião foi a organização do processo de coleta das fontes em África, ocorrido entre os anos de 1965 e 1969. Neste trabalho, posteriormente realizado pela UNESCO, a Comissão destacou os seguintes pontos: a) formação de quadros técnicos africanos para a coleta de dados; b) levantamento de fontes ainda não conhecidas, especialmente as de tradição oral; c) realização de encontros de especialistas em tradição oral, visando à construção de uma metodologia científica sobre o assunto; d) difusão de conhecimentos sobre métodos de conservação das fontes; e) ajuda na formação, organização e integração de centros de documentação em países africanos; f) alerta para que os países membros da UNESCO e o Conselho Internacional de Arquivos se esforçassem na coleta e difusão de fontes sobre a África, especialmente em relação a aquelas que se encontram sob propriedade privada; g) publicação de guias com as fontes africanas, a serem utilizados na escrita da história da $H G A$. Dados os apontamentos práticos, a reunião foi considerada por seus participantes como o encontro final da fase preliminar de preparação da $H G A$ (UNESCO, 1966a, pp. 3-5).

Além da definição de objetivos de curto prazo para a realização da $H G A$, a reunião de Abidjan traçou algumas questões de mais longo prazo, relevantes para a escrita da história que deveria emergir do projeto. A primeira era o caráter científico da história pensada na $H G A$. Nota-se também a preocupação em enfatizar o caráter essencial que a tradição oral teria para esta; assim como a centralidade do trabalho interdisciplinar. Em especial, na relação entre História, Linguística e Arqueologia. Também foi defendida a ideia de que a escrita da história da $H G A$ deveria construir uma visão totalizante da África, voltada à descrição do continente como um todo relacionado (UNESCO, 1966b, pp. 6-8).

O direcionamento prático da reunião de Abidjan guiou os passos seguintes da HGA. Ao longo dos anos de 1965-69, se organizaram as pesquisas de campo, a criação dos centros de pesquisa e documentação (sobretudo da tradição oral), a compilação de inventários e arquivos, preparação de eventos e simpósios internacionais, para debater 
temas relativos à história da África ${ }^{14}$. Após este trabalho, no início da década de 1970 , se iniciou a publicação do material recolhido, com o título de Guia das Fontes Históricas da história da África. Este trabalho inicial foi importante para a redação da $H G A$.

\subsubsection{Organização e início da obra (1969-75)}

Após a reunião de Abidjan outros encontros com grupos menores foram realizados para normatizar o trabalho de levantamento de fontes e organização de institutos, que vinha sendo feito pela UNESCO, entre 1965 e 1969. Em 1969, por exemplo, ocorreu uma reunião administrativa em Paris. Esta foi importante por ter sido a reunião que encaminhou a $H G A$ para a segunda fase de seu projeto, visando a escrita da obra. Mas muitas das decisões fundamentais em relação a este novo caminho foram tomadas na reunião seguinte da Comissão para a História Geral da África, ocorrida entre 22 e 26 de junho de 1970, em Adis Abeba, capital da Etiópia.

A reunião de Adis Abeba foi organizada por uma nova comissão, recém-eleita. O presidente foi o professor Akilulu Habte (Etiópia). Havia três vice-presidentes, Mohammed El Fasi (Marrocos), Abbé A. Kagame (Ruanda) e J. Franco (Cuba). Os secretários executivos eram os professores J. F. Ajayi e J. Devisse. Neste núcleo central havia, portanto, três remanescentes da ultima reunião de Abidjan: J. Devisse, M. El Fasi e J. Ajayi. Além destes, havia outros três intelectuais que estiveram presentes nas duas reuniões, mas que não ocuparam cargos específicos em Adis Abeba: J. Ki-Zerbo,

\footnotetext{
${ }^{14}$ Este é um detalhe que merece consideração. Além de propiciar a convivência mútua e reuniões de trabalho regulares dos maiores especialistas da área, no Conselho Executivo e no Comitê Científico Internacional, o projeto da $H G A$ organizou uma grande quantidade de Seminários e Conferências que foram realizados, ao longo da década de 1970, sobre temas relativos à história da África. Foram pelos menos dez encontros: a) "O povoamento do Antigo Egito e a decifração da escrita Meroítica" (Egito, 1973); b) “A contribuição da África Central para a história da África” (Zaire, 1972); c) "Descolonização em África: África Sudoeste e Chifre da África" (Polônia, 1978); d) "Historiografia do Sudoeste da África" (Botswana, 1977); e) "Historiografia da África Austral" (Botsuwana, 1977); f) "Metodologia da história da África Contemporânea" (Alto Volta, 1979); g) "África Negra e o Mundo Árabe" (Paris, 1979); h) "Seminário sobre Toponímia e Etnonímia" (Paris, 1978); i) "Simpósio sobre o Tráfico de escravos em África" (Haiti, 1978); j) "Os contatos históricos entre o Leste da África e Madagascar e o Sudoeste Asiático, pelo Oceano Indico" (Ilhas Mauricio, 1974). Em 1979, seis destes encontros (a, h, i, d, g, c) já haviam sido publicados, em resumo, na coleção História Geral da África: fontes e documentos. Além disto, havia o apoio dado a diversos outros eventos à época como, por exemplo, os Congressos Internacionais de Africanistas. É algo que, sem dúvida, comprova mais uma vez a importância do projeto da $H G A$ para o desenvolvimento da pesquisa histórica sobre a África, dentro e fora do continente.
} 
Hampaté Bã e D. Mc Call. Estes seis intelectuais foram fundamentais neste momento inicial da $H G A$, pois mantiveram uma presença constante nas reuniões do projeto. Havia também novos membros nesta Comissão. Eram seis professores, que não haviam participado da reunião de Abidjan: Cheikh Anta Diop (Senegal), Musa Galal (Somália), V. L. Grottanneli (Itália), E. Haberland (Alemanha), I. Hrbek (Tchecoslováquia), A. Letnev (URSS), I. Tshibangu (Republica Democrática do Congo). Os representantes da UNESCO nesta reunião foram os professores N. Bammate, R. Uwechue, G. Provenchere e M. Gléglé (UNESCO, 1970b, p. 1).

A reunião de Adis Abeba foi decisiva porque nela se estabeleceram as regras gerais de funcionamento do Comitê Executivo (CE) e do Comitê Científico Internacional (CCI, desde então: Comitê Científico Internacional para a Redação de uma História Geral da África) responsáveis pela HGA. Ademais, foi a reunião em que, após a análise das fontes agregadas pela UNESCO, se estabeleceu a quantidade (oito) e o conteúdo essencial dos volumes que formariam a $H G A$. Trata-se de um direcionamento que, no fundamental, seria seguido na publicação da obra nas décadas de 1980 e 90.

Em relação ao primeiro ponto a reunião de Adis Abeba indicou os parâmetros que foram, posteriormente, adotados no funcionamento institucional do projeto. Nesta estrutura havia dois órgãos permanentes: a) Conselho Executivo (CE); b) Comitê Científico Internacional (CCI). O primeiro era formado por um pequeno número de integrantes. Estes teriam reuniões mais regulares e menos custosas, para acelerar a realização da obra. A ideia da Comissão reunida em Adis Abeba é que, assim, o fundo financeiro existente - considerado insuficiente pelos integrantes da reunião - poderia ser gasto nas pesquisas para a $H G A$, e não em reuniões administrativas.

Os membros do CE seriam escolhidos em votação no Comitê, para um mandato de dois anos. Fariam parte do CE um presidente, cinco vice-presidentes e um secretário geral. As regras de funcionamento do CE também seriam definidas pelo Comitê, que seria a máxima autoridade do projeto. O Comitê deveria se reunir pelo menos uma vez a cada dois anos. Ele decidiria sobre as questões gerais da $H G A$; quando necessário, por voto. Ele deveria também manter-se em contato constante com os membros do CE e o Diretor Geral da UNESCO, para informar acerca da continuidade do projeto. Os membros do Comitê seriam também escolhidos por votação, atendendo as indicações do 
Diretor Geral da UNESCO ou dos próprios membros deste. A secretaria do Comitê seria indicada pelo Diretor Geral da UNESCO (UNESCO, 1970c, pp. 15-19).

Além desta organização administrativa mais geral, a Comissão indicou alguns pontos específicos. Dentre estes, vale destacar aqueles que foram criados com a nítida intenção de garantir que a $H G A$ fosse, eminentemente, um projeto coordenado pelos pesquisadores africanos. Neste sentido, a Comissão defendeu que o Comitê fixasse, em seu estatuto, que os pesquisadores africanos fossem maioria dos integrantes do Comitê (dois terços) e do CE (4 membros). Ademais, decidiu que os editores dos volumes, eleitos pela Comissão, fossem pesquisadores africanos. Estes pontos foram encaminhados pela Comissão como parte de um estatuto para o Comitê Científico a ser criado em 1971, em Paris, França. Ali se votaria o estatuto da entidade (UNESCO, 1970c, pp. 15-19; UNESCO, 1970b, pp. 11-14).

Concomitantemente, a reunião decidiu outros pontos importantes em relação à divisão e ao conteúdo da $H G A$. Destaca-se, nesta reunião, a formação de um quadro mais amplo e completo dos pontos a serem seguidos, nesta segunda fase da $H G A$ :

a) O conceito de História Geral da África significa, essencialmente, que o continente deva ser entendido como uma totalidade;

b) A História Geral da África deve ser vista desde o seu interior, partindo do próprio continente como centro de interesse, considerando os africanos como sujeitos e não meros objetos da história;

c) $\mathrm{O}$ foco deve ser sobre a história das ideias e das civilizações; ele objetiva uma síntese científica disto;

d) A abordagem não pode ser dogmática, mas problemática, aberta, buscando o conhecimento atual sobre o assunto, de acordo com o estado atual das pesquisas, suas tendências, sem omitir indicações, quando necessário, sobre divergências entre os especialistas, e sobre o que ainda precisa ser conhecido, em pesquisas futuras (UNESCO, 1970b, p. 3, tradução nossa).

A reunião de Adis Abeba, portanto, foi um encontro fundamental para a construção da $H G A$. Em primeiro lugar, pela organização administrativa do projeto. Em segundo, pela indicação do conteúdo temático básico, que foi seguido posteriormente. Em terceiro lugar, porque a reunião consolidou a posição de coordenação dos pesquisadores africanos na condução do projeto da $H G A$, como parte do estatuto da Comissão Científica. Algo que foi ratificado na primeira reunião deste, em Paris (1971). 
Por outro lado, a reunião de Adis Abeba (1970) é importante para esta análise porque foi neste encontro que, pela primeira vez, os organizadores da obra explicitam a ideia de que um das características fundamentais desta seria construir uma "história internalista" da África. Nos termos originais: “A História Geral da África deve ser vista desde o seu interior, partindo do próprio continente como centro de interesse, considerando os africanos como sujeitos e não meros objetos da história".

As questões primordiais levantadas nesta reunião de Adis Abeba foram estabelecidas estatutariamente na primeira reunião do Comitê Científico Internacional para a Redação de uma HGA, que ocorreu em Paris entre 30 de Março e 08 de Abril de 1971. Nesta reunião estiveram presentes a maioria dos indicados nas reuniões anteriores, assim como novos componentes, indicados por países africanos (Vansina, 1993, p. 339). A sua primeira tarefa foi aprovar o estatuto do Comitê Científico da $H G A$. Após isto, foi votado o primeiro CE do projeto, responsável pela coordenação dos trabalhos da $H G A$. Foram eleitos os seguintes professores: a) presidente do CE: Aklilu Habte (Etiópia); b) vice-presidentes: Bethwell Ogot (Quênia), Cheikh Anta Diop (Senegal), Ivan Hrbek (Thecoslováquia), J. F. Ajayi (Nigéria) e G. Mokhtar (Egito). Para secretário executivo do CE foi escolhido J. Devisse (França). Os demais participantes desta primeira reunião do Comitê foram os seguintes professores: A. Adu Boahen (Gana), J. D. Fage (Inglaterra), J. L. Franco (Cuba), M. H. I. Galaal (Somália), V. L. Grottanelli (Itália), E. Haberland (Alemanha Oriental), E. Boubou Hama (Níger), H. E. A. Hampaté Bã (Mali), F. A. Kagame (Ruanda), I. N. Kimambo (Tanzânia), J. KiZerbo (Alto Volta), A. Letnev (URSS), D. F. Mc Call (E.U.A.), L. Ngcongco (Lesoto), D. T. Niane (Guiné), Ravoajanahary (Madagascar), M. Shibeika (Sudão) e J. Vansina (Bélgica). A secretaria desta reunião do Comitê ficou a cargo dos seguintes representantes da UNESCO: R. Hoggart, N. Bammate, M. Gléglé, G. S. Métraux e G. Provenchere. Há de se destacar a participação majoritária de pesquisadores africanos entre os participantes da reunião e membros do CE e do Comitê Científico da HGA.

O estatuto votado pelo Comitê oficializou, em 16 artigos, as linhas gerais da organização administrativa elaborada nas reuniões preparatórias da $H G A$. Além da instauração do Comitê e do CE, o estatuto integrou à sua redação final as regras de porcentagem ( $2 / 3$ do Comitê; 4 membros no $\mathrm{CE}$ ), pelas quais os pesquisadores africanos garantiam, oficialmente, os cargos centrais e o corpo majoritário de integrantes do projeto. Por outro lado, normatizava as obrigações mútuas entre os principais 
envolvidos neste projeto, a saber, o CE, a Comissão, os editores, os autores e a própria UNESCO, por intermédio do seu Diretor Geral e do secretariado. Para a Comissão, a reunião de Paris estabeleceu também as normas específicas de seu funcionamento, num total de 33 artigos (UNESCO, 1971, Anexo II, pp. 1-9). Vê-se aí a intenção dos organizadores em estabelecer, no pormenor, as regras de funcionamento do projeto da $H G A$.

A reunião também votou os professores que se tornaram os editores dos oito volumes da obra, todos africanos: a) Volume $1^{\mathrm{o}}$ : Joseph Ki-Zerbo; b) Volume $2^{\mathrm{o}}$ : G. Mohktar; c) Volume $3^{\text {o: }}$ H. E. El Fasi; d) Volume 4: D. T. Niane; e) Volume $5^{\text {o: }}$ B. Ogot; f) Volume 6 ${ }^{\text {: }}$ J. F. Ade Ajayi; g) Volume $7^{\text {o: }}$ A. A. Boahen; Volume $8^{\text {o: Ali }}$ Mazrui. Ali se consolidou também o conteúdo temático de cada um destes volumes, que pouco se alterou posteriormente. $\mathrm{Na}$ medida em que cada tema foi restrito a uma Comissão particular do Comitê, nomeada para isto, pode-se saber quem foram os pesquisadores que elaboraram este conteúdo básico da HGA. Foram eles: Ajayi (presidente), Ki-Zerbo (secretário executivo), Fage, Vansina, C. A. Diop, Kagame, Kimambo, Boahen, Grottanelli, Niane, Shibeika, Haberland e Letnev.

Outra decisão importante votada pelo Comitê, em Paris, foi a de acelerar a concretização da HGA. Tendo-se em conta os pesquisadores participantes e as fontes agregadas ao projeto, decidiu-se que os primeiros volumes a serem produzidos e publicados seriam os de número I, II e V (UNESCO, 1971, p. 2).

Em relação ao conteúdo da $H G A$, a reunião de Paris retomou, de forma mais pormenorizada e com algumas modificações, o que fora levantado pelas reuniões anteriores, em relação à abordagem e às temáticas gerais da obra. Para isto, foram indicados os seguintes pontos, que definiriam as características da escrita da história na $H G A$ :

1) Visando a melhor qualidade científica possível, a História não pretende ser exaustiva, mas uma obra de síntese que evita o dogmatismo. Neste sentido, em muitos aspectos, ela constitui um relato de problemas indicadores do estágio atual dos conhecimentos e das grandes correntes de pesquisa, não hesitando em assinalar, em tais circunstâncias, as divergências de opinião. Desta forma, prepara o caminho para pesquisas futuras.

2) Neste trabalho a África é considerada como um todo. Assim, pretende-se mostrar as relações históricas entre as diferentes partes do 
continente, que, nas obras publicadas até hoje, em geral aparece subdividido.

3) A História Geral da África é, em particular, uma história de ideias e de civilizações, sociedades e instituições. Ela introduzirá os valores da tradição oral, assim como as múltiplas formas da arte africana.

4) Neste projeto, a história da África é essencialmente vista a partir da própria África. Trata-se de uma obra erudita que, em grande medida, é também o reflexo da maneira como os autores africanos veem sua própria civilização. Ainda que seja elaborada dentro de um quadro internacional e se utilize de dados científicos atuais, a História será também um elemento importante para o reconhecimento do patrimônio cultural africano e colocará em evidência os fatores que contribuíram para a unidade do continente. Esse esforço em examinar os fatos a partir de seu interior é a característica inovadora do projeto e deverá, ao lado de suas qualidades científicas, conferir-lhe uma grande significação. Ao mostrar a verdadeira face da África, esta obra poderia, numa época dominada por disputas econômicas e técnicas, propor uma concepção particular dos valores humanos (UNESCO, 1971, p. 2, tradução nossa)

Vê-se aí a indicação das características gerais da obra: a) abordagem científica e democrática; b) que visa à totalidade da África, com suas inter-relações regionais; c) focada na história das sociedades, civilizações e instituições, valorizando as contribuições da tradição oral e da arte africana; d) busca de um conhecimento da África por ela mesma, a partir do ponto de vista dos autores africanos sobre sua própria história, o reconhecimento do patrimônio cultural africano e os fatores que contribuíram para a unidade do continente.

Destaca-se este último ponto por ser um desenvolvimento do debate em torno da "perspectiva africana” da $H G A$. Ele é praticamente o mesmo ponto que será depois assinado por B. Ogot, na já citada Apresentação do projeto (1979). Tal fato mostra que, longe de ser algo pessoal ou pontual, estes postulados da $H G A$ faziam parte de um trabalho coletivo, que já estava definido em 1971.

Como se observou, na reunião de Adis Abeba (1970), tal perspectiva foi definida como uma visão “internalista” da África, em que “A História Geral da África deve ser vista desde o seu interior, partindo do próprio continente como centro de interesse, considerando os africanos como sujeitos e não meros objetos da história”. A mesma ideia esta presente na primeira sentença, já citada, sobre o assunto em Paris (1971): "Neste projeto, a história da África é essencialmente enfocada sob o ponto de vista da 
própria África". A continuação do ponto, entretanto, acrescenta um elemento novo a esta definição. Vale citar novamente:

Trata-se de uma obra erudita que, em grande medida, é também o reflexo da maneira como os autores africanos veem sua própria civilização. Ainda que seja elaborada dentro de um quadro internacional e se utilize de dados científicos atuais, a História será também um elemento importante para o reconhecimento do patrimônio cultural africano e colocará em evidência os fatores que contribuíram para a unidade do continente. Esse esforço em examinar os fatos a partir de seu interior é a característica inovadora do projeto e deverá, ao lado de suas qualidades científicas, conferir-lhe uma grande significação. Ao mostrar a verdadeira face da África, esta obra poderia, numa época dominada por disputas econômicas e técnicas, propor uma concepção particular dos valores humanos (UNESCO, 1971, p. 2, tradução nossa).

Em suma, defende-se aí uma "perspectiva africana" para a história da $H G A$, como um internalismo que estudaria a África por ela mesma, a partir do ponto de vista dos autores africanos sobre sua própria história, o reconhecimento do patrimônio cultural africano e os fatores que contribuem para a unidade do continente. Trata-se de uma modificação substancial do que se definiu por "perspectiva africana" em Adis Abeba (1970). Voltar-se-á a esta questão.

Por outro lado, pode-se aí observar que, em seus aspectos gerais, a reunião de Paris buscou manter uma linha de continuidade com os trabalhos das reuniões precedentes. Tal fato tende a mostrar que existia ali uma intenção dos agentes em fazer o projeto ir adiante, para além das suas divergências pontuais. Este fato é o que o professor Fernando Mourão (2009), único brasileiro participante do projeto, indica como sendo um dos méritos que tornou possível este amplo projeto de cooperação intelectual: a disposição para concretizar o projeto, para além das divergências pontuais. Para ele, algo alicerçado na crença de que a $H G A$ era algo social e cientificamente importante para a época, dado o avanço dos povos africanos rumo às suas independências políticas.

O fato é que, na reunião de Paris, em 1971, após seis anos de sua oficialização na UNESCO, o projeto da $H G A$ estava finalmente delineado em suas características gerais, tanto nos aspectos administrativos, quanto temáticos. A partir de então, tratar-se- 
ia de organizar a escritura e a publicação da obra. Por isto, se considera esta reunião a mais importante do projeto (Vansina, 1993, p. 339).

Os anos entre 1972 e 1975 marcam o período inicial de concretização da obra. Nesta etapa, conforme pode-se observar das fontes primárias, haviam quatro dificuldades primordiais que se impuseram aos organizadores. A primeira destas eram as constantes ausências de historiadores africanos importantes para o projeto, como Bethwell Ogot e Ali Mazrui. A segunda foi o atraso na redação e na editoração dos primeiros volumes a serem publicados, que já deveriam estar finalizados em 1974. A terceira foi a falta de participação de muitos membros da Comissão, que não respondiam aos contatos do CE. Por fim, havia os desentendimentos quanto ao conteúdo dos capítulos, entre editores e autores ${ }^{15}$. São incidentes que ajudaram a acirrar os ânimos dos participantes, entre 1975-78. Neste período, a polêmica sobre a "perspectiva africana" para a história da África fica evidente.

\subsubsection{Anos polêmicos (1975-78)}

Os anos mais polêmicos do projeto se iniciam na $5^{\text {a }}$. Reunião do CE, em Fez, Marrocos, em Fevereiro de 1975. Neste encontro, devido aos atrasos relativos à redação dos capítulos, por diversos motivos, atentou-se para que os primeiros volumes da obra, I e II, inicialmente prometidos para fins de 1974, só seriam entregues para tradução e exame, em fins de 1975. O andamento dos demais volumes também foi discutido, de forma pormenorizada, nesta reunião. Mais uma vez, o CE alertou para que os membros do Comitê fossem mais prestativos, quando requisitados a realizar leituras comentadas ou indicações de autores, para o bom andamento da obra. Sobre isto, o relatório diz que "como é óbvio, apenas alguns membros do Comitê responderam as comunicações (da secretaria da UNESCO, pelo CE) perguntando sobre os seus pontos de vista" (UNESCO, 1975, p. 5, tradução nossa).

\footnotetext{
${ }^{15}$ Os quatro últimos pontos são citados, por exemplo, na carta (confidencial à época) de Junho de 1976, do Presidente do Comitê, Habte, e do Secretário Geral do Projeto, J. Devisse, para o Diretor Geral da UNESCO, acerca dos problemas a serem solucionados para a continuidade do projeto. Ver: UNESCO, 1976, pp. 1-6.
} 
É difícil saber a razão exata deste problema. Por um lado, tais organizadores, especialmente quando integravam o $\mathrm{CE}$, reclamavam da baixa cooperação dos demais membros do Comitê. Por outro, quando o Comitê se reunia, acusava-se o CE de excessiva centralização no trabalho de organização da $H G A$. O fato é que esta querela revela uma disputa crescente entre o CE e o Comitê, em relação ao andamento do projeto.

Parte desta polêmica era consequência da diferença de ritmo entre os dois órgãos. Isto porque, até fevereiro de 1975, o CE já havia se encontrado cinco vezes (Cairo, 1971; Butare, 1972; Lusaka, 1973; Adis Abeba, 1974; Fez, 1975), enquanto que o Comitê só havia realizado duas reuniões (Paris, 1971; Lusaka, 1973). Tal fato trouxe um descompasso entre os dois órgãos. Em especial, em relação a decisões do CE que, para se tornarem ratificadas, dependiam da aprovação do Comitê.

Concomitantemente, essa participação tímida dos membros do Comitê atrasava o trabalho árduo de leituras e releituras a que cada capítulo estava submetido, de acordo com as normas e regimentos internos do projeto. Isto fica evidente nas reuniões do Comitê $\left(3^{\mathrm{a}}\right.$.) e do CE (6 ${ }^{\mathrm{a}}$.), ocorridas simultaneamente em Cotonou, no Benin, em Julho de 1975. É impressionante observar o preciosismo das críticas, ali presentes, sobre centenas de capítulos da obra. Estes eram enviados a todos os membros do Comitê e, por vezes, a outros especialistas do tema, que não estavam envolvidos diretamente no projeto.

Como aponta J. Vansina (1993, p. 340), tais correções e comentários não eram enviados diretamente aos editores dos volumes, mas aos relatores de cada volume. Estes eram membros do Comitê, que trabalhavam anonimamente com os editores. Tais relatores recebiam as informações e sintetizavam o que achavam pertinente. Seja como for, é espantoso observar a enorme quantidade de correções e complementações que eram discutidas nas reuniões do $\mathrm{CE}$ e do Comitê, revendo os textos originais, acrescentando ou suprimindo fotos, palavras ou frases, mapas, glossário, notas, bibliografias etc. Tratava-se de um trabalho complexo, que só poderia ser feito com a participação de dezenas de intelectuais comprometidos.

É certo, entretanto, que entre tais organizadores se encontravam poucas pessoas. Na década de 1970, período crucial de concretização do trabalho, é possível que este número girasse em torno de vinte intelectuais, que ficavam obviamente 
sobrecarregados. Além dos oito editores (Ki-Zerbo, Mokhtar, El Fasi, Ogot, Niane, Ajayi, Boahen e Mazrui) pode-se aí, salvo melhor juízo, elencar: Vansina, Diop, Devisse, Franco, Gléglé, Fage, Letnev, Kagame, Vercoutter, Habte, Tshibangu, Shibeika, Hrbek e Grottanelli. Entre os professores que entraram em 1975, apenas Obenga, Mourão, Talib e Mutibwa, começaram a participar regularmente das reuniões ${ }^{16}$. Entre estes, vale destacar que, tanto Vansina (1993, p. 342), quanto Mourão (2009), ressaltaram a importância da participação de M. Gléglé na construção do projeto.

De um modo geral, tratava-se de um esforço que visava dois objetivos primordiais. Primeiramente, aumentar ao máximo o caráter informativo e explicativo dos textos. Em segundo lugar, torná-los mais didáticos. Tal análise pormenorizada, entretanto, levou a atrasos consideráveis. Este foi o caso, por exemplo, do primeiro volume da obra. Iniciado em 1971, ele deveria estar pronto em 1974. Mas ele passou por um processo grande de reescritura entre 1976 e 1977, só sendo finalizado em 1978.

Vale dizer, todavia, que apesar deste preciosismo, não se encontra na análise das atas das reuniões do CE e do Comitê, até 1975, críticas à perspectiva interpretativa dos autores da obra. O que existe, geralmente, são apontamentos gerais, visando à discussão dos conteúdos presentes nos volumes.

Há, entretanto, duas exceções a esta regra, entre 1975 e 1978, que merecem ser comentadas. A primeira delas é o debate acerca do Volume VIII da obra, editado pelo professor Ali Mazrui. Só neste volume foram dois dias de trabalho na reunião de Cotonou, em 1975.

De um modo geral, pode-se crer que tal fato é explicável por este ser um volume que tratou de temas atuais, a saber, a África pós-1935. Todavia, observando o relatório de Cotonou, é visível que a maior parte do debate girou em torno de outra questão. Trata-se da abordagem que o editor, Ali Mazrui, deu ao tema. Tal fato é explicitado no relatório do $\mathrm{CE}$, quando este afirma que o tema requereria uma abordagem voltada para o "ponto de vista mais africano", do que o que vinha sendo produzido pelo editor. Em suas palavras: “(...) O CE espera que o Editor do Volume deva esforçar-se por caracterizar a questão tratada de um ponto de vista mais africano, em vez de um

\footnotetext{
${ }^{16}$ Acerca da participação dos novos integrantes do Comitê e dos presentes nas reuniões do CE, ver: UNESCO, 1977a, p. 19.
} 
puramente pós-colonial" (UNESCO, 1975b, p. 7, tradução nossa). Não é definido o que seria esta perspectiva nas atas. Mas o assunto é retomado em seguida, quando os organizadores buscam sumarizar seus comentários ao editor:

Cada capítulo deve se iniciar com uma seção tratando, desde um ponto de vista continental, do problema em análise. Esta consideração geral deve ser ilustrada com o estudo de casos individuais. O CE tem freqüentemente achado casos não muito representativos neste sentido. Ademais, a possibilidade de falar de mais de dois casos individuais para comparação não deve ser rejeitada a priori.

Várias propostas vêm sendo submetidas ao Editor do Volume em Lusaka e em outras ocasiões, e vem sendo apresentadas também a ele por membros do Comitê. O CE espera que estas propostas se reflitam em uma nova lista de conteúdos (UNESCO, 1975b, p. 9, grifos originais, tradução nossa).

Ou seja, por um "ponto de vista mais africano" entende-se, neste caso, a capacidade do editor de colocar o problema de análise do seu volume desde um ponto de vista continental, que deveria ser ilustrado com casos particulares.

Buscando encaminhar uma solução para o problema, o CE, em Cotonou (1975) levanta a possibilidade de um co-editor para o volume. Foi lembrado o professor A. Zolberg, belga, da Universidade de Chicago. No entanto, o CE se pronunciou a favor de um professor africano, que poderia complementar o conhecimento do editor em relação à África Ocidental (UNESCO, 1975b, p. 9) ${ }^{17}$.

Este debate sobre o Volume VIII destoa, sem dúvida, dos demais da obra, que contém críticas pontuais aos autores e praticamente nenhuma aos editores. Tal fato leva a crer que as críticas a Mazrui revelam que os organizadores da $H G A$ viram, em sua postura teórica, uma ameaça ao andamento já elaborado para a obra. Afinal, tratava-se de um editor de volume.

A participação central de tais organizadores nos aspectos teóricometodológicos da escrita da história na $H G A$ reaparece, diretamente, na discussão do Volume VII, referente ao século XIX em África. Observa-se tal fato quando o editor do volume, A. Boahen, alerta ao CE acerca da necessidade que este teve de notificar aos

\footnotetext{
${ }^{17}$ Em 1984, C. Wondji, da Costa do Marfim, foi indicado para co-editor (Vansina, 1993, p. 345).
} 
autores de seu volume, que ali se tratava de "uma história da África vista como um todo, a partir de uma visão essencialmente interna" (UNESCO, 1977b, p. 24). Sobre isto, o CE se posicionou dizendo que os autores deviam buscar superar uma visão de história ali presente, de que a África e os africanos seriam passivos na história, à espera de serem conquistados pela superioridade europeia. Nas palavras do CE:

É conveniente evitar as expressões ambíguas e os clichês históricos que dão uma má impressão da vida africana e de fatos marcantes de sua história. Neste sentido, se tem encontrado por diversos capítulos, notadamente os primeiros, a ideia de que a Europa conquistou a África devido a "deficiências inerentes às sociedades africanas", sem que estas deficiências sejam definidas por um critério próprio das sociedades africanas, mas unicamente por uma comparação com as civilizações tecnológicas europeias. Do mesmo modo, é conveniente descartar toda expressão que perpetua o velho clichê da "passividade africana" ou da eterna referência à "iniciativa europeia" e às "reações africanas" nesta época. O CE não demanda que os autores abandonem todo espírito crítico ou que façam sistematicamente laudativos a respeito das sociedades e dos povos africanos, mas deve-se evitar o vilipêndio automático e os erros de perspectiva que tanto prejudicaram a qualidade do trabalho sobre a África. Se um soberano africano se mostra um sanguinário, é necessário descrevê-lo com tal e justificar suas afirmações, mas deve-se evitar qualificar por isto todos os chefes de Estado africanos que se opuseram aos europeus, sob a categoria de tiranos sanguinários, que oprimem seu povo e pilham territórios vizinhos (UNESCO, 1977b, pp. 24-25, tradução nossa).

Além desta observação geral, o CE faz uma crítica pormenorizada dos capítulos que formam o volume, pedindo correções e complementações. Indica-se também novas fontes, materiais, terminologias (suprimindo termos outrora comuns como paganismo, fetichismo, animismo) etc. (UNESCO, 1977b, p. 29). Em alguns casos, se propõe a troca de autores, que não responderiam às comunicações do editor. É um posicionamento radical dos organizadores, visando adequar a visão dos autores a uma "perspectiva mais africana" da temática, conforme suas palavras. Algo que o CE qualifica como uma "mudança de espírito".

Tal postura do CE mostra o seu apoio à linha interpretativa da "perspectiva africana", construída pela $H G A$ e por Boahen, em contraposição à visão de história de alguns dos autores do referido volume. Este exemplo mostra que, quando o CE acreditava que esta "perspectiva" não estava sendo de fato incorporada na escrita da 
história da $H G A$, havia uma forte oposição do grupo organizador da obra. Esta posição sofrerá um redirecionamento, a partir de 1978.

\subsubsection{A vitória do pragmatismo (1978-82)}

Após a reunião do $\mathrm{CE}$ em Paris, duas reuniões simultâneas em Nairobi, no Quênia, entre Abril e Junho de 1978, do CE ( $8^{\circ}$.) e do Comitê (4º), deram continuidade à concretização do projeto. Elas contaram com praticamente a mesma configuração dos últimos encontros.

Um diferencial destas reuniões em Nairobi foi que elas estavam voltadas, majoritariamente, para a discussão de questões administrativas relacionadas à publicação da obra. Em especial, em relação aos dois primeiros volumes que seriam publicados no ano seguinte: Metodologia e pré-história da África (I) e A África Antiga (II). Destaca-se a preocupação dos membros do Comitê em garantir uma divulgação ampla desta publicação, especialmente em África. Tais apontamentos ressaltam: a) a necessidade de proceder à tradução dos volumes para o árabe, visto que estes seriam inicialmente publicados em francês e inglês; b) a viabilização, por via contratual, do barateamento do preço final da obra; c) a difusão da $H G A$ por programas públicos de comunicação de massa.

Em relação à discussão dos demais volumes da obra, é observável que, em Nairobi, as questões formais se tornariam dominantes em relação às discussões de conteúdo, que haviam predominado nos encontros anteriores. A mudança é drástica, merecendo explicação. Mesmo em relação ao Volume VIII, coordenado por Mazrui, o relatório realça que sua rediscussão, segundo as atas, foi realizada em uma "atmosfera mais construtiva", do que outrora (UNESCO, 1978, p. 11). O que explicaria tal redirecionamento repentino?

Pode-se conjecturar algumas razões para o fato. A primeira é que os debates em torno do conteúdo da obra poderiam ser então menos necessários; fosse porque já ter-seia construído uma posição consensual sobre a temática e a linha interpretativa, fosse porque os organizadores já teriam consolidado sua posição face aos demais. Uma segunda razão poderia ser o atraso nos prazos estabelecidos. Afinal, o projeto estava 
inicialmente projetado para ter-se finalizado em 1978, ano em que apenas dois volumes da obra estavam prontos.

As duas hipóteses, em tese, são validas, mas é difícil crer que elas justificariam tal mudança repentina no andamento do projeto. Mesmo porque muitas questões continuavam em aberto, como, por exemplo, o conteúdo do Volume VIII, editado por Ali Mazrui.

A resposta para esta questão parece estar num fato novo destacado nas atas da reunião do Comitê de Paris, em 1977. Lê-se ali que, "pela primeira vez durante o andamento do projeto", o Diretor Geral da UNESCO apareceu nas reuniões dos seus organizadores (UNESCO, 1977b, p. 34). O referido diretor era o senegalês M. A. Mahtar M’Bow. Alguém que, desde sua eleição, em 1974, teve um papel fundamental na sustentação do projeto da HGA na UNESCO (Mourão, 2009).

Nesta visita, descrita pormenorizadamente nas atas da referida reunião, M’Bow veio garantir o apoio da UNESCO ao projeto da $H G A$. É interessante, entretanto, que, em suas palavras, M’Bow faça questão de destacar a importância de que a $H G A$ não seja uma obra dogmática, mas democrática e aberta, mostrando o que ainda precisaria ser melhor pesquisado sobre a história da África. Diz a ata:

O Diretor Geral insistiu sobre a ideia que esta História, como sublinhou o Comitê desde a sua primeira seção, não venha a ser dogmática, que ela não venha dissimular nem as insuficiências nem as lacunas atuais da pesquisa; afinal ela traz uma revelação de grande importância: a metodologia dos historiadores de todos os países e uma fonte de informação sobre o passado africano, insubstituível aos africanos, mas todo ele necessário aos demais habitantes da terra (UNESCO, 1977b, p. 34, tradução nossa).

Ao se observar a história do projeto da $H G A$, como aqui vem sendo feito, é evidente que, ao destacar o princípio democrático do projeto, nesta fala, o Diretor Geral da UNESCO agia visando à defesa de uma posição que ele via como algo em perigo, diante da ação de alguns dos organizadores da obra. Neste sentido, a crítica ao dogmatismo, ali reforçada, servia como uma crítica indireta a estes. Daí a referência sobre o necessário espírito democrático em uma obra como esta. Isto, exatamente em 
um momento em que os organizadores da obra se viam pressionados pelo excesso e atrasos de trabalho e pelo aumento de polêmicas internas da obra.

Sobre este assunto, A. Ajayi, como um dos presidentes do CE, expôs algumas das dificuldades que se interpuseram. Explicou que, diante delas, foi necessário prorrogar a existência do Comitê Científico e do próprio CE, de 1978, como havia sido planejado até, pelo menos, 1982. A promessa era de que os dois primeiros volumes da obra estivessem prontos para publicação, em fins de 1978. Não consta a resposta de M’Bow (UNESCO, 1977b, p. 40).

Pela mudança repentina que se pode observar no andamento das reuniões, entre Paris (1977) e Nairobi (1978) é crível, pois, que a presença do Diretor Geral da UNESCO, no último dia da reunião de Paris, em 1977, fez com que a pressão por uma ambiente mais tolerante às visões divergentes a posição dominante sobre a "perspectiva africana" ali delineada, tenha produzido efeitos nos participantes.

É neste novo ambiente que se voltou a temas polêmicos, em Nairobi, como o Volume VIII, coordenado por Mazrui. Aí, na reunião do $\mathrm{CE}$, se retomaram críticas pontuais aos capítulos deste volume. Todavia, não aceitando tais apontamentos, Mazrui defendeu a adoção de uma edição coletiva do volume, algo que o secretariado da UNESCO julgou impossível pelo estatuto da obra.

O tema é retomado na reunião do Comitê, na mesma cidade, nos dias seguintes. Aí, devido ao impasse criado, os membros do Comitê resolvem mudar de opinião. E, segundo consta, com a objeção de alguns, decidem aceitar a proposta original de Mazrui para o conteúdo do Volume oitavo, conforme este tinha apresentado na reunião de Cotonou (1975) (UNESCO, 1978, pp. 36-43).

Entretanto, a decisão final sobre o conteúdo deste volume só foi tomada em 1979, em uma nova reunião do Comitê em Paris. Ali ficou estabelecido que a proposta original de Mazrui seria mantida, com um acréscimo de capítulos que permitisse estender as temáticas relativas à política interna africana. Ou seja, a solução foi uma conjunção de interesses entre o que o editor originalmente desejava, e algo do que foi agregado pelos membros do Comitê. Isto se tornou possível porque há uma ampliação quantitativa deste volume específico, que passou a ter 30 capítulos. Não resta dúvida, entretanto, que esta vitoria do editor é um exemplo do novo ambiente criado 
internamente, condicionado pela pressão do Diretor Geral da UNESCO por um "ambiente democrático", visando a finalização do projeto.

A partir de 1979, pode-se observar que as questões de forma, tradução e acesso a obra tornam-se as preocupações prementes dos organizadores da $H G A$ e das reuniões do CE e do Comitê. Tratava-se, em suma, de finalizar a obra, que consumiu um trabalho de décadas aos organizadores. Desde então, e até a finalização da obra, nos anos 1990, esta visão mais pragmática da $H G A$ é a marca dominante da história institucional do projeto.

\subsection{A "perspectiva africana" na metodologia da $H G A$}

Uma exposição mais pormenorizada e pessoal das principais questões metodológicas da $H G A$ se encontra na Introdução do Volume I, escrita pelo historiador J. Ki-Zerbo, um importante participante do projeto. Por isto, é necessario uma investigação mais detalhada deste artigo, comparativamente aos demais.

Em sua Introdução, Ki-Zerbo retoma alguns objetivos gerais da $H G A$, já apontados nos textos do Prefácio e da Apresentação do Projeto, escritos, respectivamente, por $\mathrm{M}^{\prime}$ Bow e B. Ogot. O primeiro destes objetivos é que a reescrita da história da África, ali projetada, deveria ser vista como parte de um processo maior de tomada de consciência dos povos africanos sobre si mesmos. Seria, pois, uma história ligada à construção da identidade. Realizar este objetivo, para Ki-Zerbo, dependeria do fato de que esta reescrita fosse realizada sob a égide da ciência. Em suas palavras, a "única matriz da consciência desalienada e autêntica". É sobre estes dois pilares que se fundaria o projeto da $H G A$. Diz o autor:

Com efeito, a história da África, como a de toda a humanidade, é a história de uma tomada de consciência. Nesse sentido, a história da África deve ser reescrita. E isso porque, até o presente momento, ela foi mascarada, camuflada, desfigurada, mutilada (...) Não se trata aqui de construir uma história-revanche, que relançaria a história colonialista como um bumerangue contra seus autores, mas de mudar a perspectiva e ressuscitar imagens "esquecidas" ou perdidas. Tornase necessário retornar à ciência, a fim de que seja possível criar em todos uma consciência autêntica. É preciso reconstruir o cenário 
verdadeiro. É tempo de modificar o discurso. Se são esses os objetivos e o porquê desta iniciativa, o como - ou seja, a metodologia - é, como sempre, muito mais penoso (Ki-Zerbo, 2010a, p. XXXIII, aspas originais).

Dito isto, Ki-Zerbo busca sintetizar quais seriam os aspectos teóricometodológicos que possibilitariam esta reescrita da história da África. A direção desta busca seria um caminho intermediário entre a singularização excessiva da África e universalização a-crítica, que levaria a alinhá-la demasiadamente a normas estrangeiras (Ki-Zerbo, 2010a, p. XXXIV).

Para tal, inicialmente, Ki-Zerbo observa que a história da África deveria ser guiada pelas normas e procedimentos fundamentais da razão, sobretudo em relação à aplicação do principio de causalidade. Esta percepção, todavia, deveria ser complementada pelo fato de que, na pesquisa humanística, tais princípios universais de racionalidade, na medida em que visam à investigação de problemas e realidades distintas, também deveriam se diferenciar, visando uma compreensão precisa e firme do objeto de estudo. É neste sentido que se coloca, para ele, a questão sobre os métodos e técnicas específicas da história da África.

Neste sentido, Ki-Zerbo retorna ao princípio da "perspectiva africana" no final desta Introdução. Aí, ele afirma que a história da África da $H G A$ deveria ser vista como uma história vista desde o interior, a partir do "pólo africano". Para o autor, fazer a história desde o "pólo africano" significaria realizar uma história com consciência de si mesma, em prol da constituição de uma personalidade coletiva autônoma. Tratar-se-ia de uma "opção e uma ótica do auto-exame".

Para Ki-Zerbo, dizer isto não significaria que a história da África pudesse, por exemplo, abolir a realidade histórica das relações da África com os outros continentes. Mas que tais conexões deveriam ser analisadas destacando os intercâmbios recíprocos e de influências multilaterais, nos quais as contribuições de valor positivo da África para a humanidade seriam postas em relevância. Afinal, após tantos séculos de visões deturpadoras e preconceituosas sobre a África, dever-se-ia, em seus termos, resgatar a visão interior de identidade, autenticidade e conscientização. 
Em suma, o autor fala ali de uma visão que, sem negar as exigências da ciência universal, recuperasse a historicidade desse continente, em novos modelos. Ou seja, nesta história nova da África, não se poderia negar a importância dos influxos exteriores para a história do continente, mas se deveria favorecer uma análise que revelasse as contradições e os dinamismos endógenos. E, desde tal ponto de vista, quando for o caso, perceber como estes moldaram os influxos externos. Citando o autor:

Outra exigência imperativa é que essa história seja enfim vista do interior, a partir do pólo africano, e não medida permanentemente por padrões de valores estrangeiros; a consciência de si mesmo e o direito à diferença são pré-requisitos indispensáveis à constituição de uma personalidade coletiva autônoma. Certamente, a opção e a ótica de auto-exame não consistem em abolir artificialmente as conexões históricas da África com os outros continentes do Velho e do Novo Mundo. Mas tais conexões serão analisadas em termos de intercâmbios recíprocos e de influências multilaterais, nas quais as contribuições positivas da África para o desenvolvimento da humanidade não deixarão de aparecer. A atitude histórica africana não será uma atitude vingativa nem de auto-satisfação, mas um exercício vital de memória coletiva que varre o campo do passado para reconhecer suas próprias raízes. Após tantas visões exteriores que tem modelado a marca registrada da África a partir de interesses externos (até nos filmes contemporâneos), é tempo de resgatar a visão interior de identidade, de autenticidade, de conscientização (...). É preciso aqui uma verdadeira revolução corpernicana, que seja primeiramente semântica e que, sem negar as exigências da ciência universal, recupere toda a corrente histórica desse continente, em novos modelos (Ki-Zerbo, 2010a, pp. LII-LIII).

É interessante que o autor, ao detalhar o que seria esta visão do interior que definiria a "perspectiva africana", não fala que esta deveria o ponto de vista dos autores africanos sobre sua história e civilização, como aparece na Apresentação de B. Ogot. Ele trata deste "pólo africano" como uma visão historiográfica que aliasse identidade, autenticidade e conscientização, privilegiando a contribuição positiva que os valores africanos possam dar à humanidade.

Estas colocações de Ki-Zerbo são importantes, porque mostram pequenas divergências, interessantes para este estudo, dentro das normas padrões criadas pelos organizadores da $H G A$. 
A defesa deste viés interpretativo, de uma perspectiva africana para a história da África, é parte substancial de alguns dos artigos mais célebres deste primeiro Volume da $H G A$, voltados ao estudo das tradições culturais em África. São eles: Lugar da história na sociedade africana (Joseph Ki-Zerbo \& Boubou Hama), A tradição oral e sua metodologia (Jan Vansina) e A tradição viva (Hampaté Bã).

Dentro do escopo de análise aqui estabelecido, pode-se atentar para algumas convergências e divergências aí estabelecidas. A principal convergência é a tentativa dos autores em justificar uma perspectiva africana para a historiografia, desde um estudo das tradições africanas. Aí esta o cerne de suas contribuições. A defesa deste ideal é que se faz de modos distintos. Ora complementares, ora divergentes.

O artigo de Hampaté Bã, um dos mais importantes na bibliografia sobre África, trabalha com a ideia de tradição oral africana. Sua premissa é dar a esta tradição oral o mesmo valor da tradição escrita. Afinal, ambos seriam válidos enquanto testemunhos. $\mathrm{E}$ o que se encontra por detrás do testemunho seria o próprio valor do indivíduo que o faz. Mais exatamente, o valor de cada cadeia de transmissão da qual ele faz parte, a fidedignidade das memórias (individual e coletiva) e o valor atribuído à verdade em uma determinada sociedade. Em suma: a ligação entre o Homem e a palavra (Bã, 2010, p. 168). É a partir deste principio que o autor defende a visão de uma perspectiva africana do saber. Referindo-se à vasta região sul-saariana, Bã observa que, para além de sua diversidade, as tradições africanas aí constituídas teriam certas características comuns. É sobre isto que ele reflete.

Bã afirma que, para entender este ponto, seria preciso compreender que as sociedades orais teriam duas características distintas em relação às sociedades escritas. A primeira é que, por sua importância social, a formação da memória tenderia a ser mais desenvolvida. A segunda é que, ali, haveria também uma ligação mais forte entre o Homem e a palavra. Afinal, onde não existiria a escrita, o Homem estaria diretamente ligado à palavra que profere. Estaria comprometido com ela, na medida em que encerraria um testemunho daquilo que ele é.

Estas características comuns às sociedades orais se complementariam, na África ancestral, por outras que lhe seriam próprias. Aí o autor fala em esclarecer a tradição oral africana a partir do seu interior. Ou seja, a partir de uma "perspectiva africana". Isto porque, nas tradições africanas abaixo do Saara, diz Bã, a palavra, além de ter um 
valor moral fundamental, possuiria um caráter sagrado vinculado a sua origem divina e às forças ocultas nela depositadas. Algo que concorreria para preservar a fidelidade da transmissão oral. Daí que o autor afirme que a tradição oral basear-se-ia em uma certa concepção do Homem, do seu lugar e do seu papel no seio do universo.

Segundo Bã, todas as tradições africanas sul-saarianas postulariam uma visão religiosa de mundo. Nesta, o universo visível seria concebido e sentido como sinal, a concretização ou o envoltório de um universo invisível, constituído de forças em perpétuo movimento. No interior desta unidade cósmica, tudo se ligaria, tudo seria solidário, e o comportamento do homem em relação a si mesmo e em relação ao mundo que o cerca (mineral, vegetal, animal e sociedades) seria objeto de uma regulamentação ritual muito precisa cuja forma variaria, segundo as etnias ou regiões (Bã, 2010, p. 173). Por isto, a violação das leis sagradas causaria uma perturbação no equilíbrio das forças que se manifestaria em distúrbios de diversos tipos. A ação mágica, ou seja, a manipulação das forças, geralmente almejaria, assim, restaurar o equilíbrio perturbado e restabelecer a harmonia, da qual o Homem havia sido designado guardião, por seu Criador. Em suma, a mentira, numa cultura como esta seria um erro mortal, pois ela mata a pessoa civil do indivíduo. Quando alguém mente, se separaria de si mesmo. Romper-se-ia assim a unidade sagrada, cósmica, criando desarmonia dentro de si e ao redor.

Segundo Bã, este saber tradicional, em África, esteve, historicamente, ligado a uma atividade ou a um ofício ancestral: ferreiros, tecelões etc. É isto que explicaria a formação das “castas”. Daí também, a disposição para conservar e reproduzir um saber específico, que faz parte desta visão total do Homem (Bã, 2010, p. 189).

Estas particularidades da memória africana e sua transmissão oral, segundo o autor, não teriam sido afetadas pela islamização, pois esta ter-se-ia adaptado, sempre que possível, às tradições africanas. A simbiose por isto seria muito grande, tornando-se difícil distinguir o que viria de uma tradição ou de outra. Seja como for, nas duas tradições teriam sido mantidas as mesmas características: a) preocupação na citação de fontes; b) não modificação da palavra do mestre, respeito pela transmissão; d) mesmo sistema de caminhos iniciatórios. Assim, buscar-se-ia aprofundar pela experiência aquilo que se conhece pela fé. 
O que fica evidente destas asserções de Bã é sua crença no poder da imersão cultural do pesquisar como único caminho para que este adentre nos modos de pensar desta sociedade. Só assim poder-se-ia interpretar suas tradições. Trata-se, portanto, de uma premissa epistemológica.

Uma interpretação próxima acerca da tradição em África pode ser encontrada no ensaio de Boubou Hama e J. Ki-Zerbo: Lugar da história na sociedade africana. Aí, entretanto, o foco não é a tradição oral, mas a concepção "tradicional" de história na África sul-saariana. Argumentam os autores que, enquanto homens e mulheres como quaisquer outros, os africanos possuíam, em suas sociedades tradicionais sul-saarianas (pré-coloniais), medidas diferenciadas do tempo, extraídas de percepções míticas, naturais ou sociais. Tal complexidade da percepção temporal poderia ser analisada na vida cotidiana, em que se somariam a visão mítica, percepções do tempo derivadas de fontes naturais (mudanças climáticas, variações pluviais, sazonais) e sociais (escrita, linhagens, povo). Por isto, dizem eles, as racionalizações sobre o tempo nas sociedades africanas seriam essencialmente dinâmicas, derivadas de diferentes fontes e contexto. Aí poder-se-ia encontrar a marca de uma historicidade humana aberta ao novo. Afinal, não se trataria de uma visão estática do tempo (Hama \& Ki-Zerbo, 2010, p. 34).

Assim como Bã, portanto, Hama \& Ki-Zerbo entendem o conhecimento prévio da tradição nas sociedades africanas como uma premissa epistemológica do historiador de África. Tais argumentações reivindicam uma imersão cultural e uma abertura de espírito necessária ao trabalho historiográfico. Não se trata aí, propriamente, de uma discussão metodológica, mas uma assertiva epistemológica sobre as possibilidades do conhecimento.

Neste particular, o ensaio de Vansina (A tradição oral e sua metodologia) se coloca desde outro enfoque. Seu tema são os pressupostos metodológicos do historiador em relação à tradição oral, buscando dar fundamento à sua utilização como fonte histórica, ou melhor, como história oral. Seu enfoque é certamente mais específico, embora não menos importante. Em comum com os autores anteriores, entretanto, Vansina concorda com uma ideia fundamental antes aventada, de que a tradição oral não deve ser vista pelo historiador como uma carência, uma falta de habilidade ou capacidade de uma sociedade, mas como uma atitude diante da realidade (Vansina, 2010a, p. 139). 
Para Vansina, as características primordiais da tradição oral, entendida como elocuções-chave que guardam um testemunho transmitido oralmente de uma geração para outra, seriam o verbalismo e sua maneira de transmissão. Eles difeririam das fontes escritas. O autor faz algumas observações importantes sobre estes dois pontos. Em primeiro lugar, destaca o problema de origem da narrativa. Para ele, só as tradições baseadas em narrativas de testemunho oculares deveriam ser válidas para a construção de fontes históricas. Limitadas a este critério, caberia analisar as tradições orais sob três aspectos complementares: a) como obras literárias; b) em sua inserção no meio social que as cria e transmite; c) a partir da visão de mundo que sustenta o conteúdo de qualquer expressão de uma cultura (Vansina, 2010a, pp. 142-144). Boa parte do artigo de Vansina visa demonstrar e exemplificar esta última observação, mostrando como a utilização de uma metodologia adequada ao estudo das tradições em África deveria partir tanto de critérios gerais - sobretudo em relação ao primeiro ponto - quanto específicos, que embasariam a análise do contexto social da tradição. Em verdade, é sobretudo neste ponto que o autor se detém. Em suas palavras:

Poderíamos ser tentados a seguir alguns estudiosos que acreditavam poder dizer a priori qual a natureza ou perfil do corpus de tradições históricas de uma determinada sociedade, a partir da classificação das coletividades em tipos como "Estados", "sociedades sem Estado", etc. Embora seja verdade que as diversas sociedades africanas possam ser, grosso modo, classificadas de acordo com tais modelos, é fácil demonstrar que essas tipologias podem se estender ao infinito, pois cada sociedade é diferente, e os critérios utilizados são arbitrários e limitados. Não existem dois Estados idênticos ou mesmo semelhantes nos detalhes (...) Generalizações apressadas sobre o valor das tradições seriam absolutamente despropositadas. O perfil de um determinado corpus de tradições só pode ser determinado a posteriori (Vansina, 2010a, p. 147, itálicos originais).

Embora apontem para tendências diferentes de abordagem - algumas mais generalizantes, como as de Bã e Hama \& Ki-Zerbo, e outra mais específica, como a de Vansina -, as continuidades em relação a estes três trabalhos sobre as tradições orais africanas, tendem a concordar quanto ao principal. Sem dúvida, os textos de Bã e Hama \& Ki-Zerbo são mais enfáticos sobre o tema, tratando a tradição como algo a ser estudado por si mesmo, enquanto que Vansina vê a tradição como algo a ser depurado, para tornar-se fonte histórica. Mas os pontos de aproximação são evidentes. Destaca-se, 
sobretudo, que todos os autores falam de um ideal de imersão cultural africana, supostamente necessário a todos os interessados em entender a tradição oral (ou as tradições orais) deste continente.

Isto pode ser observado tanto nas sínteses apresentadas por Bã e Ki-Zerbo, quanto na defesa das especificidades, proclamada por Vansina. Pode-se aí, em verdade, observar dois modelos de compreensão da "perspectiva africana". O primeiro focado nos elementos comuns, essenciais; o segundo na especificidade. São duas formas distintas de responder ao desafio de escrever uma história endógena da África.

Outra pista interessante sobre a "perspectiva africana" se encontra na discussão metodológica sobre a relação entre Linguística e História, que percorre cinco artigos do primeiro Volume da HGA. Fala-se dos seguintes: a) História e Linguística, de P. Diagne; c) Migrações e diferenciações étnicas e linguísticas, de D. A. Olderogge; d) Classificação das línguas da África, de J. H. Greenberg; e) Mapa lingüístico da África, de D. Dalby. Os textos de T. Obenga (Fontes e técnicas específicas da história da África: panorama geral) e outro de Joseph Ki-Zerbo (Teorias relativas às "raças" $e$ história da África) também tratam secundariamente desta questão.

De um modo geral, parece haver uma unidade fundamental nesta nova linguística africana (pós-45), aqui representada pelos artigos de Obenga, Greenberg, Olderogge, Dalby e Diagne. Esta unidade advém da tentativa de desconstruir o mito da origem camita de certas línguas africanas. Trata-se de um mito que legitimou, por décadas, uma visão racista da África. Isto porque, vendo-se o camita como uma língua dos "povos indo-europeus", os progressos no continente eram atribuídos, direta ou indiretamente, à influência destes povos. Outro aspecto consensual que pode ser observado nestes artigos é a crença de que a Linguística seria uma ferramenta fundamental para o estudo da história na África Pré-Histórica e Antiga - especialmente a. C. O caso dos povos Bantu, neste sentido, é exemplar (Olderogge, 2010, p. 314).

Todavia, há uma polêmica interessante nestes artigos, que merece consideração. Trata-se das críticas de diversos autores desta seção - especificamente, Dalby, Olderogge e Diagne - ao mapa linguístico dos povos africanos, desenvolvido pelo pesquisador estadunidense J. Greenberg, autor também presente na $H G A$. 
Pode-se esquematizar estas críticas em dois sentidos. Em primeiro lugar, diz-se que as interpretações de Greenberg seriam simplórias, pois suas tipologias se agrupariam sobre aspectos restritos e, por vezes, aparentes, da estrutura das línguas africanas (Diagne, 2010a, p. 250; Olderogge, 2010, p. 312; Dalby, 2010, pp. 342-343). Por outro lado, elas seriam etnocêntricas, pois, a partir de sua definição da família afroasiática (egípcio, berbere e semítico), ele estaria re-estabelecendo a crença na genealogia mediterrânica dos africanos da África Setentrional. Algo que remeteria à velha teoria camita, que o próprio Greenberg teria ajudado a desconstruir (Diagne, 2010a, p. 262; Olderogge, 2010, p. 314).

Esta última crítica parece a mais importante para os demais estudiosos da $H G A$. Não por acaso, sobre este último ponto, ao falar sobre a integração do berbere ao afroasiático, vê-se a seguinte nota de rodapé no artigo de Greenberg:

Nota acrescentada a pedido de um membro do Comitê: esta classificação não é apenas contrária às opiniões de pesquisadores alemães, mas também à verdade cientifica pura. Os lingüistas norteafricanos apontaram os motivos políticos que levaram a escola colonialista francesa a classificar a língua berbere entre as línguas camito-semíticas. A realidade é que o berbere é uma língua semítica, e mesmo uma das mais antigas línguas dessa família, juntamente com o acadiano e o hebraico. Assim, não é nem camito-semítico nem afroasiático, como se diz em outras partes deste capítulo. Ver, particularmente, em árabe: M. El-Fasi. O berbere, língua-irmã do árabe. Atas da Academia do Cairo, 1971 (Greenberg, 2010, p. 324).

O leitor não se enganou. No artigo de Greenberg, consta uma nota dizendo que sua classificação do berbere como afro-asiático não é científica. É difícil crer que tal nota foi aceita de bom grado pelo autor. Mais importante do que isto, todavia, é que esta inclusão mostra as reservas da maioria dos membros do Comitê, para com a tipologia da família afro-asiática, estabelecida pelo linguista estadunidense. Por mais criticadas que as demais famílias de Greenberg fossem pelos demais autores, não há nenhuma interferência direta do Comitê para comentar estas. Em suma, o problema era esta tese particular.

Visando superar a teoria camita, supostamente renovada por Greenberg, os demais autores da HGA citados - Obenga, Dalby, Diagne e Olderogge - constroem uma 
argumentação voltada para legitimar os estudos linguísticos, que visavam à comparação interna das línguas africanas, em busca de suas semelhanças. Obenga, por exemplo, destaca a possível correlação entre o egípcio antigo e as demais línguas africanas sulsaarianas (Obenga, 2010, p. 67). Dalby, por outro lado, observa que esta unidade deveria ser buscada na "zona de fragmentação sub-saariana". Neste caso, o egípcio antigo não seria a fonte original, mas apenas uma das ramificações desta difusão maior e mais antiga (Dalby, 2010, p. 340). Diagne, por sua vez, apesar de defender uma visão interna e unitária das linguas africanas, afirma que ainda é cedo para a construção de teorias generalizantes, pois ainda haveria muito trabalho empírico a ser feito (Diagne, 2010a, p. 281). Da mesma forma, Olderogge dá suporte a esta perspectiva, mas não inova nas consequências teóricas que ela poderia ter para a escrita da história.

Não é o intento deste trabalho avaliar quais destas teorias (assim como muitas outras aqui apresentadas) seria mais bem sucedida do ponto de vista científico. Aliás, algo impossível de ser realizado por apenas um pesquisador. Mas, seja como for, aí estão caminhos interessantes a serem pensados quando se pretende construir uma história da África, conforme idealizada pelos organizadores da $H G A$ : desde uma "perspectiva africana". Neste caso, internalista, científica e visando a unidade africana.

Após esta síntese dos vários argumentos acerca do que se poderia indicar como uma "perspectiva africana" na $H G A$ cabe sintetizar, por fim, o que seria esta prerrogativa interpretativa.

\subsection{Definindo a "perspectiva africana" e suas abordagens}

A análise empírica aqui realizada apontou vários elementos e temáticas que problematizaram a ideia da "perspectiva africana", que embasaria a escrita da história da $H G A$. Ou, pelo menos, de grande parte desta obra.

Inicialmente, a partir da Apresentação de B. Ogot, observou-se que tal "perspectiva africana" poderia ser interpretada como uma visão histórica interna à própria África. Algo que se estabeleceria, “em larga medida”, pelo estudo da África a partir do ponto de vista que os próprios autores africanos teriam sobre sua civilização, 
sobre o patrimônio cultural africano e sobre os fatores que contribuíram para a unidade do continente. No entanto, a própria utilização da expressão "em larga medida" revelava as dificuldades de se postular uma definição não problemática desta "perspectiva africana", que os intelectuais da $H G A$ buscavam edificar.

A investigação desta perspectiva na história institucional do projeto revelou algumas faces desta polêmica. A questão primordial parecia ser a luta dos organizadores da $H G A$, sobretudo, a partir do CE, para assegurar que a história ali escrita tivesse "um ponto de vista mais africano". O que seria isto efetivamente? Em muitas ocasiões, tratava-se de uma "história internalista" da África, em que os africanos deveriam ser vistos como sujeitos de sua própria história. Nos termos originais, descritos na reunião de Adis Abeba (1970): “A História Geral da África deve ser vista desde o seu interior, partindo do próprio continente como centro de interesse, considerando os africanos como sujeitos e não meros objetos da história". A mesma ideia é retomada em 1975 , quando o CE defendeu a postura de A. Boahen, editor do Volume VII, por uma "uma história da África vista como um todo, a partir de uma visão essencialmente interna”.

Mas em outros momentos, mais raros, esta defesa de uma visão mais africana aparece como uma história escrita de um "ponto de vista mais continental", como nas atas da reunião de Cotonou (1975). Como se viu, o mesmo ponto de vista aparece em alguns textos da seção sobre Linguística e História, especialmente em Obenga e Dalby.

A visão internalista da África, como o cerne da "perspectiva africana" ali construída, é também central nas considerações de J. Ki-Zerbo, em sua Introdução à obra. Ali se fala da história desde o pólo africano, enquanto opção e ótica de autoexame. Nas eloquentes palavras do autor, tratar-se-ia de uma visão interior de identidade, autenticidade e conscientização que, sem se negar as exigências da ciência universal, recuperasse toda a corrente histórica do continente africano, em novos modelos.

Como se observou, esta visão internalista é também destacada pelos artigos que tratam da tradição africana como meio e objeto de estudo: Lugar da história na sociedade africana (Joseph Ki-Zerbo \& Boubou Hama), A tradição oral e sua metodologia (Jan Vansina) e A tradição viva (Hampaté Bã). A defesa deste ideal se faz de modos distintos, mas o princípio é o mesmo: só aprofundando o conhecimento sobre 
a tradição (ou tradições) africana é que poder-se-ia compreender as realidades históricosociais do continente.

No mesmo sentido, a maioria dos autores da $H G A$, citados na seção de História e Linguistica - Obenga, Dalby, Diagne e Olderogge - constroem uma argumentação voltada para a comparação interna das línguas africanas, em busca de suas semelhanças. Ao fazê-lo, buscam reorientar as análises linguísticas, que usualmente estudariam as semelhanças de algumas destas línguas, com outras externas a África.

Uma primeira investigação, portanto, que abarcou a história institucional e a parte metodológica da $H G A$, desvelou aqui um significado essencial e consensual da “perspectiva africana” como uma visão internalista da própria África. Esta parece ser a diretriz realmente integrada à obra. Diante desta percepção majoritária, duas questões envolvidas no delineamento da "perspectiva africana", nesta análise, se mostraram secundárias e divergentes, quais sejam: a) a história da $H G A$ como o ponto de vista dos intelectuais africanos sobre sua própria civilização; b) a história como busca da unidade africana.

No trabalho de pesquisa que deu origem a este trabalho, esta percepção da "perspectiva africana" foi se consolidando, concomitantemente, conforme se realizava o trabalho de leitura e análise da escrita da história nos oito volumes que formam a $H G A$. Isto porque, ali, foi-se revelando existir uma divisão importante a ser considerada. De um lado, haviam os artigos preocupados em enfatizar fatores internos como elementos determinantes de sua explicação para a história da África (“internalismo”). De outro, havia os artigos que não se importavam com tal perspectiva ou, por outro lado, destacavam fatores externos à própria África, em sua explicação da história do continente ("externalismo"). Sendo o primeiro grupo majoritário sobre o segundo, se confirmou a crença de que a visão internalista e científica da África era uma premissa realmente dominante do trabalho historiográfico ali realizado ${ }^{18}$.

\footnotetext{
${ }^{18}$ Vale dizer que, assim como pode-se observar da história institucional do projeto, o fato da maioria dos autores da $H G A$ serem africanos, pode ter garantido a posição hegemônica dos internalistas sobre os externalistas, mas não traz uma identificação de posições historiográficas e local de origem do autor. Ou seja, ser um intelectual africano não determina ser internalista. O mesmo pode ser dito em relação aos especialistas não africanos e o "externalismo". Esta é uma das razões principais do porque não se deve confundir a "perspectiva africana" aqui trabalhada, como o ponto de vista dos intelectuais africanos, sobre a sua própria história. Veja-se, por exemplo, a posição externalista na explicação da história, em artigos de autores africanos, como em T. Chenntouf. O Chifre da África e a África Setentrional. In: Mazrui \&
} 
A complementação destes dois processos de pesquisa empírica - a investigação da história institucional do projeto e a análise da escrita da história na $H G A$-, portanto, foi que possibilitou a definição da "perspectiva africana", que orienta este trabalho. Ela é aqui entendida como a abordagem que privilegia os fatores internos ao continente, em oposição aos externos, na explicação histórica, científica, da África.

O trabalho dos próximos capítulos será buscar comprovar, pormenorizadamente, como esta definição da perspectiva africana ${ }^{19}$ possui um fundamento empírico na escrita da história ali presente, nos oito volumes da $H G A$. Com esta demonstração, são trazidos novos elementos para a tese primordial deste trabalho: de que a perspectiva africana (conforme acima definida) é um dos legados essenciais da $H G A$ para a posteridade.

Evidentemente, esta definição da perspectiva africana limita o escopo de interpretações possíveis sobre o seu conteúdo. Mas defende-se aqui sua validade por três argumentos primordiais. Em primeiro lugar, esta definição julga abarcar o caráter essencial de um desafio proposto pelos próprios organizadores da $H G A$ : escrever uma história da África por ela mesma, desde uma perspectiva científica. Em segundo lugar, como se pretende demonstrar em seguida, tal definição é uma boa caracterização de uma unidade na diversidade, realmente existente na escrita da história da $H G A$. Isto porque, ao mesmo que ela se coloca como uma totalidade, tal definição é suficientemente elástica para abarcar a diversidade de posições internalistas da $H G A$. Por último, por ser baseada em trabalho empírico, esta definição pode, em princípio, ser contestada por qualquer outro pesquisador da área, interessado no assunto.

Ademais, esta definição da perspectiva africana permite tratá-la como uma prerrogativa historiográfica atual e universalista, que pode ser utilizada e refinada por pesquisadores de todo o mundo, independente de sua pertença nacional, étnico-racial ou mesmo ideológica. Afinal, o que a define é o comprometimento metodológico com uma percepção internalista e científica da África.

O prosseguimento da análise sobre esta perspectiva africana, agora baseado na investigação da escrita da história da $H G A$, revelou a existência de três abordagens desta

Wondji (Ed.) África desde 1935. Brasília: UNESCO, 2010. Por outro lado, há posições internalistas de autores não africanos, como em dezenas de casos que serão citados adiante.

${ }^{19}$ De agora em diante sem aspas, visto que o termo já foi definido 
interpretação da história da África; a) regionalismo; b) difusionismo intra-africano; c) sujeito africano. Daí o caráter de unidade na diversidade da perspectiva africana, aqui trabalhada. É necessário fazer novas definições.

Inicia-se pelo "regionalismo". O "regionalismo" seria um tipo de abordagem da perspectiva africana em que os autores enfatizam uma análise de longa duração, em âmbito local, dos elementos fundamentais que explicariam a história de uma região africana em particular. Tal tipo de abordagem tem por objetos de estudo primordiais, o ecossistema local (ou regional) e os desenvolvimentos (ou adequações) técnicas e sóciopolíticas das populações africanas. Trata-se, portanto, de um internalismo regionalizado.

Um outro tipo de abordagem é a que chamamos de difusionismo intra-africano. Este é outro tipo de interpretação internalista. Nesta, os elementos fundamentais que explicariam a história da África estariam na difusão de elementos e dinâmicas internas ao continente; mesmo que estes não o fossem em sua origem. Foca-se aí a ideia de movimento e troca na explicação histórica, dando-se ênfase aos fatos que atestariam tal interpretação. Seus temas típicos são os movimentos migratórios, as redes econômicas e as influências culturais, de alguns povos africanos sobre outros.

A explicação pelo sujeito africano é a última abordagem internalista da história da África, na $H G A$. Ela se coloca, nesta obra, como uma explicação histórica que visa destacar a ação política do sujeito africano, de forma mais ampla possível. Sua presença faz-se marcante, sobretudo, nos momentos históricos em que os fatores externos são estruturalmente dominantes. Este é o caso, por exemplo, da época colonial na África. Trata-se, pois, de uma abordagem que busca na ação política do africano, o último objeto de estudo do internalismo na história da África.

Destacou-se, portanto, três abordagens diferentes do internalismo da perspectiva africana: a) o regionalismo; b) o difusionismo intra-africano; c) sujeito africano. Além destas, se falou de uma explicação externalista, que não será analisada neste trabalho.

Para clarificar esta tipologia recorrer-se-á a uma exemplificação. Pode-se estudar, por exemplo, a consolidação das cidades haussa (Zaria, Kano, Katsina, Gobir e Kebbi), no século XIV, por várias abordagens diferenciadas. Como a explicação externalista entenderia esta problemática? Pode-se defender, por exemplo, que o surgimento e a consolidação de tais cidades poderiam ser entendidas a partir da 
expansão econômica árabe-muçulmana no Mediterrâneo, desde o século VII. Este argumento, tipicamente, buscaria mostrar como o urbanismo e o crescimento do comércio no Sudão Central desde esta época poderia ser visto como um reflexo do dinamismo do comércio internacional controlado pelos árabes-muçulmanos. No mesmo sentido, poder-se-ia defender que tal fato, em verdade, seria resultante de um migração árabe para a região, que poder-se-ia basear nas genealogias islamocêntricas locais, que tendem a atestar tais ilações. Nesta segunda visão, tais populações teriam trazido os elementos fundamentais para tal dinamização da história local. Por exemplo, a presença de uma "religião universalista" (muçulmana), a cultura formal escrita, uma prática comercial mais desenvolvida etc. Seja como for, nestas caracterizações, os fatores que explicariam a história das cidades haussas seriam externos ao continente africano. Estes são tipos de explicação externalista que presentes na $H G A$ (minoritariamente), mas não serão analisados nesta tese.

Como este fato histórico poderia ser explicado pela interpretação internalista, conforme as abordagens aqui citadas? Uma típica explicação regionalista, conforme a definição proposta mostraria que a consolidação das cidades haussas, no século XIV, seria apenas o cume mais perceptível de uma história de longa duração. Nesta, certos elementos fundamentais deste processo - como a presença de um grupo étnicopopulacional, desenvolvimento tecnológico, evolução da adequação sócio-ambiental das populações etc - já estariam em curso há vários séculos nesta região do Sudão Central. Seriam estes os elementos que, essencialmente, explicariam a evolução urbana da região no século XIV. Neste quadro, portanto, os aspectos conjunturais, como a interferência do comércio internacional, tornar-se-iam secundários.

Uma análise de tipo difusionista intra-africana defenderia este mesmo internalismo por outras razões. Ela poderia, por exemplo, mostrar como o surgimento de tais cidades poderia ser explicado, direta ou indiretamente, pela migração de certos grupos populacionais específicos - como os wangara - para a região do Sudão Central, em busca de novas oportunidades de comércio. Estes teriam trazido para esta região, por exemplo, não apenas novas técnicas mercantis, mas também uma vivência urbana mais desenvolvida, advinda das sociedades africanas do Sudão ocidental e do delta do Níger. Para reforçar o argumento, poder-se-ia advogar, por exemplo, uma suposta origem ou identificação mande dos wangara. O importante para caracterizar esta abordagem é que os aspectos essenciais de explicação histórica levantados - religião, economia, cultura 
etc -, sejam de caráter supra-regional e com uma dinâmica histórica africana. Ou seja, mesmo que a origem de um destes elementos seja externa ao continente - como o islamismo -, na explicação difusionista intra-africana, buscar-se-á considerá-la como algo derivado de processos históricos internos ao continente. É isto que diferencia tal abordagem do externalismo. No caso do islamismo e sua possível relação com o surgimento das cidades haussa, por outro lado, se poderia mostrar uma suposta presença muçulmana na região, como fator importante desta explicação histórica, como algo derivado de migrações de populações africanas do Sudão Ocidental ou do Delta do Níger - não da Arábia. Tratar-se-ia, portanto, neste caso, de dinamismos históricos provocados pelo "islamismo africano", que possui uma historicidade própria, diferente daquela do islamismo árabe, que lhe deu origem.

Por fim, temos a explicação histórica internalista derivada do sujeito africano. Nesta abordagem, poder-se-ia, por exemplo, defender que o surgimento das cidades haussas, no século XIV, teria sido um ato de resistência das populações locais, seja qual a sua origem primeira - local ou supra-regional -, contra o avanço das populações berberes muçulmanas no Sudão Ocidental, em busca de novos produtos para comerciar como o mundo mediterrânico e árabe: cativos, ouro, animais selvagens etc. Um bom exemplo deste expansionismo berbere no Sudão Central seria a nova dominação Séfuwa no Bornu, que se impôs aos locais, a partir do século XI.

Esta exemplificação dos tipos de abordagem citados não visa sintetizar o que está dito na $H G A$ sobre este assunto particular: o surgimento e consolidação das cidades haussa no século XIV. Muito menos inovar em tal temática. Com isto, pretendeu-se, exclusivamente, contribuir para a melhor compreensão do que foi dito anteriormente, em forma mais abstrata.

Escrita por especialistas consagrados em suas áreas, a $H G A$ possui uma quantidade e heterogeneidade de argumentações e comprovações, que em muito superam esta exemplificação simplória, utilizada para fins didáticos. Neste sentido, é importante salientar, novamente, que o propósito deste trabalho não é avaliar a qualidade científica dos artigos desta obra. Seu objetivo é sintetizar as contribuições ali estabelecidas a partir de um critério objetivo e funcional para tal investigação.

Por consequência, portanto, fica evidente que este trabalho não trará uma análise de todos os artigos da $H G A$. Isto porque, embora ele tenha se baseado nesta 
investigação prévia, seu objeto de estudo se restringe aos artigos que buscaram esta interpretação internalista da história da África. Algo em torno de $85 \%$ dos artigos da $H G A$. Os demais artigos serão citados apenas circunstancialmente, para exemplificar o contraponto a esta perspectiva africana.

Entre estes artigos suprimidos, os artigos considerados externalistas formam a maioria. Eles representam cerca de $10 \%$ dos artigos de toda a $H G A$, majoritariamente nos Volume III e VI desta. Mas constam aí também alguns outros artigos, que não se comprometiam com causas essenciais para a explicação histórica que traziam. Ou, por outro lado, enumeram diversos fatores (tanto internos, quanto externos), todos supostamente "importantes" e "inter-relacionados" para explicar um fato histórico específico. Estes são cerca de 5\% da obra, especialmente no Volume VIII. Nestes casos, para evitar generalizações descabidas, se evitou tipificá-los nos modelos estabelecidos ${ }^{20}$.

Tratando da maioria dos artigos da $H G A$, aqueles que serão aqui analisados, cabe explicitar uma característica fundamental de sua escrita da história, que possibilitou o trabalho de pesquisa ora realizado. Tal particularidade é o comprometimento dos autores como uma visão da história, que visa distinguir o essencial do secundário. Daí que os artigos da obra, em sua maioria, sejam baseados em hipóteses de trabalho circunscritas e claramente ancoradas no princípio de causalidade. Em outras palavras, são artigos que apontavam para causas essenciais que explicariam a dinâmica histórica do continente. Por exemplo, a adequação ecossistemica de determinada população, a difusão de técnicas metalúrgicas, os movimentos populacionais, a deterioração ambiental, a ação política dos africanos etc.

Outra marca destes artigos é, na verdade, algo comum a toda a $H G A$. É o fato de que, independente de serem internalistas ou externalistas, todos os artigos da $H G A$ carregarem uma visão científica e interdisciplinar da História, ancorada em uma concepção materialista, realista e empírica, do trabalho historiográfico. Este é o locus de

\footnotetext{
${ }^{20}$ Uma defesa explícita do aspecto inter-relacionado da história da África com a história mundial, como forma de atenuar a importância da distinção internalismo x externalismo na explicação histórica, se encontra no artigo introdutório de Ali Mazrui ao Volume VIII da obra: Mazrui, A. Introdução. In: Mazrui \& Wondji (Ed.) A África desde 1935. Brasília: UNESCO, 2010. Isto não impede que se analise outro artigo do mesmo autor - ou outro qualquer - neste trabalho, como internalista. Afinal, trata-se, aqui, de uma investigação sobre a escrita da história, em artigos específicos da $H G A$. Veja-se, neste sentido, por exemplo, outro artigo de A. Mazrui no mesmo volume: "Procurai primeiramente o reino político. In: Mazrui \& Wondji (Ed.) A África desde 1935. Brasília: UNESCO, 2010.
} 
enunciação dos autores da obra. E, como tal, é algo presente também na perspectiva africana, que será aqui analisada.

Nos próximos capítulos mostrar-se-á como tal perspectiva africana, sem perder a sua característica de totalidade, permite a construção de diferentes histórias da África, a partir das abordagens citadas. Daí sua caracterização como unidade na diversidade. $\mathrm{Na}$ medida em que a abordagem difusionista intra-africana é a majoritária nesta visão internalista, por ela se iniciará esta demonstração.

Todavia, antes disto, faz-se necessário uma advertência ao leitor. Neste trabalho, não se analisou a escrita da história da África relativa ao período pré-neolítico, que usualmente é indicado por volta de 9.000 a. C. Há duas razões para isto. A primeira é que, por formação profissional, ignoram-se os pormenores de tal discussão, que é realizada, na $H G A$, por paleontólogos. Em especial, em relação ao processo de hominização e as extensas investigações sobre o instrumental lítico das primeiras populações humanas. Em segundo lugar, porque, mesmo quando se ousou interpretar tais pesquisas, pouca coisa sobrou de relevante para a análise aqui realizada. Isto porque as dúvidas reinantes entre os próprios especialistas na matéria tornava irrelevante uma investigação como esta, baseada em diferentes abordagens da perspectiva africana: regionalismo, difusionismo-africano, sujeito. Por este fato, os artigos da segunda parte do primeiro volume (Metodologia e pré-história da África), só serão citados neste trabalho quando se reportarem ao período pós-neolítico.

Dito isto, vamos à análise prometida. 


\section{Capítulo 2: O difusionismo intra-africano e a história da África da $H G A$}

\subsection{Periodização}

Este capítulo traça em linhas gerais a história da África construída pela explicação difusionista intra-africana, na perspectiva africana da $H G A$. Vale lembrar os pressupostos de tal investigação. Por perspectiva africana entende-se a abordagem que dá ênfase aos fatores internos ao continente, em oposição aos externos, na reconstrução histórica da África. E, por difusionismo intra-africano, um tipo de internalismo que enfatiza o caráter de difusão dos principais fatores explicativos para a história da África, para além do âmbito regional ou local. Destaca-se, aí, a ideia de movimento e troca na explicação histórica; assim como os fatos que atestariam tal interpretação. Seus temas típicos são os movimentos populacionais, as influências culturais e o comércio intercontinental. Suas fontes principais são a Linguística e a Arqueologia.

A explicação difusionista intra-africana, assim definida, é o tipo de escrita da história mais comum na $H G A$, superando a explicação externalista, regionalista ou do sujeito africano. Sendo assim, faz-se necessário relembrar o caráter sintético da abordagem aqui realizada, que poderia ser desdobrada em centenas de páginas. Aliás, é justamente esta característica que interessa aqui destacar. Afinal, é a partir daí que se pretende desvelar as semelhanças e diferenças desta explicação histórica em relação às demais, que formam a perspectiva africana da $H G A$.

Assim como será feito nos demais capítulos, para realizar esta síntese, propõese, aqui, uma periodização de acordo com os princípios próprios da abordagem analisada. Neste caso, portanto, uma cronologia construída de acordo com o exame deste difusionismo na $H G A$. Para isto, dividir-se-á este capítulo em quatro itens. São eles: a) Neolítico e África Antiga (10 mil a. C - VII d. C; b) África entre os séculos VIIXVI; c) África entre os séculos XVI e 1880; d) África entre 1880 e fins do século XX. 


\subsection{Neolítico e África Antiga (10 mil a. C. - VII d. C.)}

A explicação difusionista intra-africana foi amplamente utilizada na escrita da história da África Antiga, na $H G A$. Buscava-se, assim, dar uma tendência internalista para uma história que, para a historiografia colonial, seria o exemplo indiscutível que justificaria o externalismo na história da África. Este era o caso das ideias racistas sobre a ocupação territorial da África (de norte ao sul do continente) por povos indo-arianos, que sustentaram o mito camita até a década de $1940^{21}$. Contra esta fantasia, todos os autores da $H G A$ se opunham.

O Neolítico na África é um tema polêmico. Isto ocorre porque em grande parte do continente, o Neolítico não se configurou, antes da presente Era, com todos os elementos que costumeiramente se atribuía ao Neolítico "clássico". Ou seja, o observado no Neolítico do Crescente Fértil (Egito e Oriente Próximo). Foi partindo desta experiência histórica particular que o termo neolítico foi cunhado. Por isto, costumeiramente se entende por este termo: o período da Pré-história recente, em que teria ocorrido o aparecimento de novas técnicas - em particular a arte da cerâmica e o polimento da pedra - e o início da domesticação de animais, da agricultura e do urbanismo (Hugot, 2010, p. 672).

Colocando-se contra esta visão etnocêntrica do Neolítico, vários autores propuseram modelos alternativos que fundamentariam este conceito, na segunda metade do século XX. Na $H G A$, a maioria dos autores não desconsidera o referido conceito. Todavia, procura relativizá-lo, buscando atestar as particularidades do Neolítico Africano, em relação ao Neolítico "clássico". Desde um ponto de vista difusionista intra-africano, pode-se atestar esta abordagem em duas importantes teorias presentes na $H G A$ : a) o povoamento saariano; b) civilização aquática. Ambas trabalham, ainda que de modo diferenciado, com a ideia de que a questão chave para compreender a história da África Antiga estaria na difusão de um modo de vida semi-nômade na região. Este modo de vida se constituiria de aldeamentos móveis formados por populações riberinhas, ao longo de rios e lagos, existente durante um período especialmente úmido do continente africano, entre 9 mil e 3 mil a. C.

\footnotetext{
${ }^{21}$ Talvez o último livro de circulação internacional a defender tal ideia tenha sido: Raças da África (1930), de G. Seligman.
} 
A primeira tese é pormenorizadamente trabalhada por H. Hugot, no artigo Préhistória do Saara (Volume I). Ali, Hugot defende a ideia de que o povoamento saariano, entre 9 mil e 3 mil a. C., teria sido o produto do entrecruzamento de seis tradições neolíticas de origens distintas que teriam existido na região, quando ali predominava o clima úmido e a vegetação de savanas. A primeira delas teria sido a tradição Sudanesa, advinda de Cartum. Posteriormente, ter-se-iam desenvolvido, localmente, outras tradições neolíticas, como o Iberomaurisiense, o Capsiense, o Tenerense, o Senegalês (ou Litorâneo) e o Nilo-guineense (ou Florestal).

Para o autor, a origem destas tradições seriam de populações nômades, formadas por caçadores-coletores-pescadores. Todavia, a partir do V milênio a. C., teria ganhado hegemonia nesta vasta região saariana, um tipo de vida semi-sedentário, formado por aldeamentos móveis, em que as tradições sudânica e capsiense tornar-se-iam predominantes. Algo que se poderia verificar pelos estilos de cerâmica locais. Nestas comunidades, embora ainda não existisse a agricultura propriamente dita $^{22}$, ter-se-ia a coleta e seleção de vegetais. Tais elementos conjuntos definiram um Neolítico Saariano ou uma proto-cultura do Saara, que teria sido um aspecto fundamental da evolução das técnicas humanas na pré-história recente africana (Hugot, 2010, p. 677).

$\mathrm{O}$ artigo de D. Olderogge (Migrações e diferenciações étnico-linguísticas, Volume I) leva a tese do povoamento saariano mais longe, destacando outros elementos. Citando a descoberta de novos vestígios de culturas neolíticas, no Cartum (Sudão; vegecultura: datada de 12 mil a. C.), no Ennedi (Hoggar; vestimentas de couro: 9 mil a. C.) e no Tissili n’Ajjer (Argélia; lareiras e cerâmica: 9 mil a. C.), o autor levanta a hipótese deque o Neolítico saariano fosse anterior ao do Crescente Fértil (costumeiramente datado de 6 mil a. C.). Isto porque, estas descobertas se somariam as já existentes. Especialmente as que comprovariam que, a partir do VI milênio, já ter-seia desenvolvido no Saara antigo a domesticação das gramíneas selvagens e o pastoreio, com a criação do gado de grande porte, ovinos e caprinos. Destes fatos, conclui o autor que dever-se-ia reconhecer o papel da África como pólo de disseminação civilizatória

\footnotetext{
${ }^{22}$ Definição de Hugot (2010, p. 673) para o termo: “Cultura racional de plantas selecionadas em áreas do solo, especialmente preparadas". A prova do conhecimento de uma agricultura poderia resultar:

- de provas palinológicas estatisticamente válidas;

- da existência de traços de terrenos cultivados;

- da coleta de vegetais fósseis identificados.

Para o autor, isoladamente. a presença de um instrumental considerado "agrícola" não tem significado preciso. Daí sua conclusão de que não se poderia falar propriamente de agricultura no caso saariano.
} 
no Neolítico, no que se refere tanto aos homens quanto às técnicas, em um dos mais importantes períodos da história humana (Olderogge, 2010, p. 300).

A segunda tese da explicação difusionista sobre a importância do Neolítico africano é a da "civilização aquática", de J. Sutton. Trata-se de uma teoria muito conhecida em fins dos anos 1970. Ela se encontra resumidamente exposta, na $H G A$, no artigo Pré-história da África Oriental (Volume I).

Neste artigo, J. Sutton defende a hipótese de que teria existido uma "civilização das águas" na Costa Oriental africana. Esta seria formada por populações ribeirinhas de economia sedentária. Tal civilização teria se estendido por todo o Sahel (Oeste e Leste), em direção ao norte pelo Nilo e, ao sul, pelos Grandes Lagos. O ápice desta civilização teria ocorrido entre 8 e 5 mil a. C. Segundo o autor, não haveria nestas comunidades ainda agricultura e sedentarismo, durante o período considerado. Mas J. Sutton acredita que o desenvolvimento da cerâmica e de uma tecnologia sofisticada associada à pesca, nos rios, lagos e pântanos, teria possibilitado estabilidade a populações ribeirinhas, por toda esta região. Poder-se-ia comprovar tal fato pela grande quantidade de anzóis, redes, facas, machados e singularidades desta cerâmica e artesanato antigo, descoberta pelos trabalhos arqueológicos em África. Ademais, a presença de espinhas de peixes, conchas de moluscos, assim como de ossadas de mamíferos e répteis aquáticos (ratos d'água, tartarugas, hipopótamos e crocodilos) nesses antigos acampamentos, sugeriria importantes dados econômicos. Também plantas teriam sido ali sistematicamente colhidas e consumidas (Sutton, 2010a, pp. 547-549).

Além de dados arqueológicos, Sutton adiciona dados linguísticos a sua tese. Neste sentido, o autor acredita que tal modo de vida antigo estaria associado à formação do grupo linguístico Nilo-saariano, estudado pelos linguistas africanistas. Isto porque, como diz o autor, a formação e a dispersão deste grupo Nilo-saariano se adequaria, cronologicamente, à sua hipótese da "civilização aquática" (Sutton, 2010a, p. 549).

J. Sutton acredita que esta civilização aquática, supostamente existente em boa parte da África, durante 8-5 mil a. C., deveria ser mais estudada pela história da África, por diversas razões. A mais importante delas é que o modo de vida ribeirinho que ela teria impulsionado teria sido fundamental para o desenvolvimento tecnológico africano e para a adequação destas populações à agricultura e ao pastoreio. Este teria se difundido na região, a partir de 3 mil a. C., advindo de levas sucessivas de povos nilóticos e etíopes. Todavia, mesmo depois desta época, o autor garante que na África 
Oriental ter-se-ia mantido a pujança de uma economia pesqueira, aliada às novas formas produtivas (Sutton, 2010a, p. 249).

Assim expostas de forma sucinta, as teorias de Hugot e Sutton parecem um tanto aleatórias. Todavia, elas se baseiam em décadas de pesquisa geológicas, linguísticas e arqueológicas sobre a África Antiga, que não cabe citar. Vale destacar, entretanto, que elas só podem ser compreendidas aceitando-se o fato de que, ao contrario dos dias presentes, o clima úmido era o dominante na África durante o período milenar trabalhado pelos autores, especialmente entre 9 e 5 mil a. C. Algo que, na HGA, é atestado nas análises de S. Diarra (Geografia histórica: aspectos físicos, Volume I, p. 348), A. Mabogunje (Geografia histórica: aspectos econômicos, Volume I, p. 371), H. Faure (Quadro cronológico das fases pluviais e glaciais na África: parte II, Volume I, p. 432) e I. Said (Quadro cronológico das fases pluviais e glaciais na África: parte I, Volume I, p. 406). É baseado neste fato que suas teorias dão centralidade ao modo de vida ribeirinho, enquanto uma característica peculiar do Neolítico africano.

O clima continua a ser um fator determinante para a explicação da historia da África, independente do tipo de explicação adotada - difusionista, regionalista ou do sujeito africano - após 2.500 a. C. A razão primordial para este fato é o progressivo ressecamento do clima, cujo exemplo máximo é a desertificação do Saara. Isto porque, para a maior parte dos historiadores e arqueólogos do primeiro volume da $H G A$, este ressecamento teria sido o fator determinante para as migrações populacionais, tidas como um fato importante para a compreensão da história da África, em fins do último milênio a. C.

Para uma explicação difusionista intra-africana da história, como a estudada neste capítulo, as migrações citadas, iniciadas com o ressecamento final do clima em África (por volta de 2.500 a. C.) são fundamentais, pois teriam trazido consigo características supostamente essenciais para a história da África Antiga. Na $H G A$, aponta-se duas migrações primordiais neste sentido: a) expansão dos cuchitas ${ }^{23}$, de norte ao sul, pela costa leste africana; b) expansão banto, da África Ocidental até a África Meridional. Para os autores que tratam desta temática, tais expansões são fundamentais porque permitiam aos historiadores construir uma macro-narrativa

\footnotetext{
${ }^{23}$ Os nomes dos povos e das regiões africanas, assim como as suas grafias, serão transcritos conforme a edição recente da $H G A$ no Brasil: UNESCO, 2010.
} 
coerente acerca da implantação de um modo de vida neolítico na África Central, Oriental e Meridional.

Em relação a migração dos cuchitas, os autores que tratam desta temática na $H G A$ são J. Sutton (A África Oriental antes do século VII, Volume II) e C. Ehret ( $O$ interior da África Oriental, Volume III). Sutton acredita que os cuchitas tenham sido os povos que trouxeram e difundiram o pastoreio do gado de grande porte, das cabras e dos carneiros à África Oriental, a partir do segundo milênio a. C. Gradualmente, tal avanço teria ocupado toda a costa leste africana, praticamente exterminando as antigas economias ribeirinhas e de caça-coleta da região. Apoiando-se em dados linguísticos, Sutton defende que estes cuchitas teriam advindo da Etiópia. Eles teriam por marcas culturais distintivas a aversão ao peixe e a importância dada à circuncisão. Para o autor, embora tais pastores não utilizassem o ferro, podem ter sido os responsáveis pelo início da agricultura na África Oriental, pois teriam cultivado o sorgo, o milhete e outras plantas (Sutton, 2010b, p. 636).

Também apoiado em dados linguísticos e arqueológicos, C. Ehret leva mais adiante esta tese da expansão cuchita, apresentada na $H G A$ por Sutton. Segundo Ehret, os cuchitas teriam chegado à África Oriental, mais especificamente, no norte do Quênia, durante no terceiro milênio a. C. Para este autor, tais povos teriam trazido para esta região um modo de vida neolítico, associado ao pastoreio. Este seria bastante diferente do nomadismo de caça e coleta dos grupos khoi-khoi e san, que lá viviam antes da chegada dos cuchitas (Ehret, 2010a, p. 725).

Além dos cuchitas, que teriam ocupado a parte meridional e leste da África do Leste, Ehret se refere ao papel fundamental que outros povos, os "centro-sudaneses" e os "nilotas", teriam tido nas partes mais centrais e oeste desta mesma região da África Oriental, na Antiguidade. Tal qual os cuchitas, tais povos seriam essencialmente pastores, que teriam estabelecido relações de reciprocidade com outras comunidades locais. Segundo Ehret, os "centro-sudânicos" teriam chegado à região do Quênia por volta do terceiro milênio a. C. Os segundos, mais tarde, por volta da metade do último milênio a. C. Nestes casos, a fundamentação de Ehret é mais linguística, do que arqueológica (Ehret, 2010a, p. 726).

Para este autor, todos os grupos citados teriam continuado a sua expansão no primeiro milênio d. C., quando teriam alcançado a África Meridional. Neste percurso, 
tais pastores teriam tido relações próximas com os agricultores banto, estabelecidos na região oeste dos Grandes Lagos, desde a metade do ultimo milênio a. C.. Para Ehret, o predomínio bantu na África Sudoeste, Leste e Meridional só ter-se-ia consolidado a partir da metade da presente Era. Isto teria sido resultado da expansão de sua economia agrícola, baseada no inhame e na utilização mais generalizada do ferro (Ehret, 2010a, p. 730).

Esta correlação que Ehret aponta entre expansão bantu, produção agrícola e utilização generalizada do ferro é o ponto chave da explicação difusionista intraafricana em relação à macro-narrativa histórica da África Central, Oriental e Meridional, entre fins do ultimo milênio (a. C.) e inicio da presente Era. M. Posnansky, por exemplo, um defensor ardoroso de toda tese difusionista intra-africana para a história da África, sintetiza esta interpretação em Introdução ao fim da Pré-História na África Subsaariana (Volume II).

Todavia, o argumento mais sofisticado sobre esta temática se encontra no artigo de J. Vansina e S. Lwanga-Luniiygo (Os povos falantes do banto e sua expansão, Volume III) $)^{24}$. Para estes autores, a expansão bantu deve ser vista como um processo histórico de longa duração e não linear. Afinal, tratar-se-iam de deslocamentos populacionais múltiplos e multi-direcionais que, iniciados por volta do início do ultimo milênio a. C., só ter-se-iam finalizado no século XII da presente Era (Vansina \& Lwanga-Luniiygo, 2010, p. 192).

Para os autores, a Linguística teria um papel fundamental na identificação dos primórdios desta expansão populacional. Estes estudos dariam uma visão ampla do que seriam as características comuns das comunidades proto-bantu (ou proto-bantas), que teriam dado origem às demais. Tais comunidades teriam se formado em regiões limítrofes entre florestas e savanas, praticando a cultura do inhame e de outras raízes e cereais. Elas também viveriam da pesca e da caça. O único animal domesticado teria sido a cabra. O parentesco seria o vinculo social mais efetivo, mas já existiria certa especialização social. A metalurgia do ferro só gradualmente, nos primeiros séculos da Era presente, ter-se-ia tornado importante para a produção agrícola (Vansina \& LwangaLuniiygo, 2010, p. 179).

\footnotetext{
${ }^{24}$ Em verdade, como se verá no quarto capítulo, trata-se de uma explicação mais relacionado ao primeiro autor, do que ao segundo. Todavia, por enquanto, destacar-se-á a parte do artigo em que a visão dos autores provavelmente coincidia.
} 
Acreditam os autores que tais características originais das comunidades bantu ter-se-iam diversificado drasticamente pela África Subequatorial. Caberia, pois, ao historiador, o estudo de como esta unidade inicial teria evoluído localmente, adequandose a novos ecossistemas e ao relacionamento com outras comunidades.

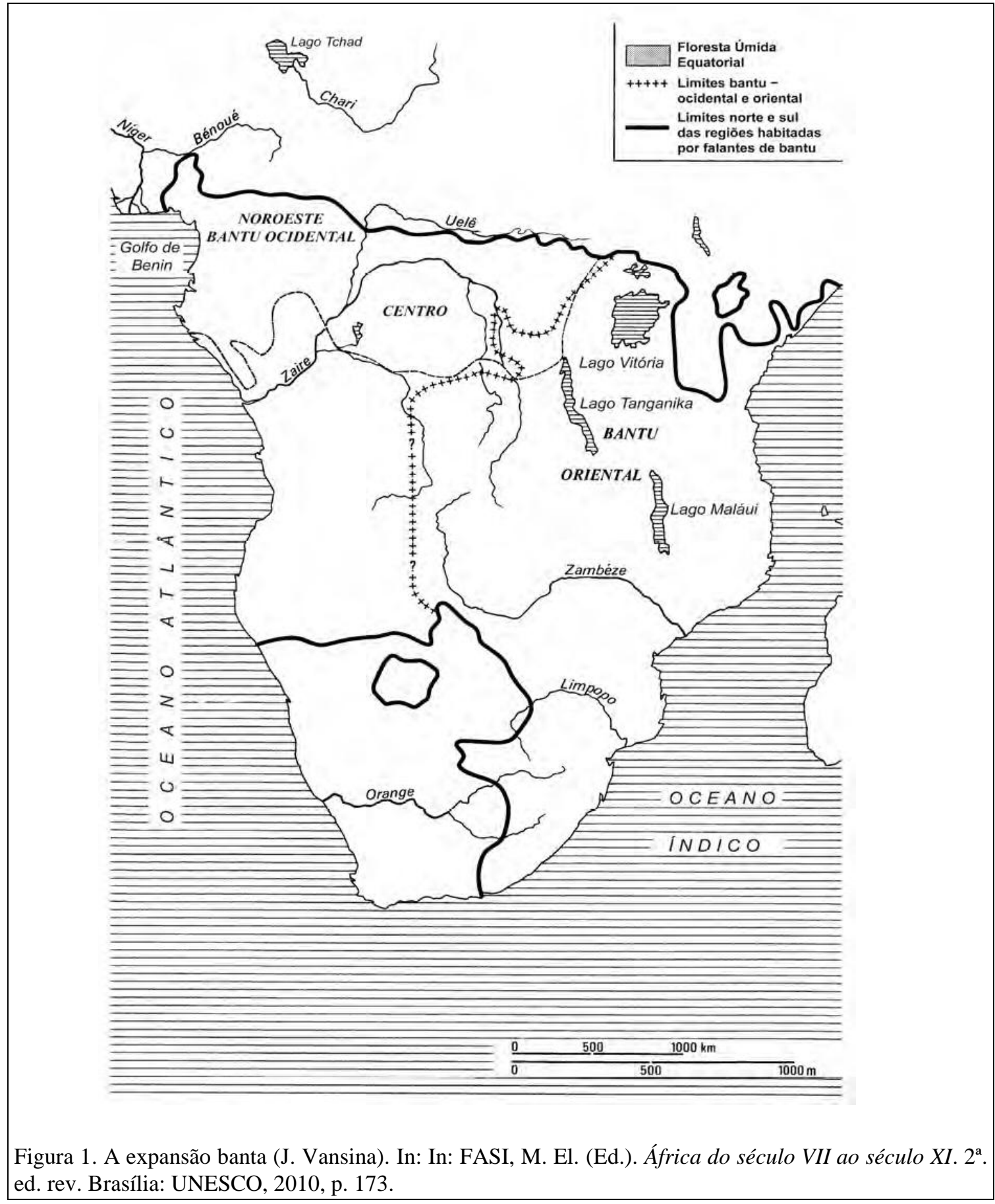

Não resta dúvida que o tipo de explicação proporcionado pela narrativa baseada na expansão bantu para o povoamento da África Austral é sólido. Esta correlação é tão 
forte que, alguns autores como D. Clark (Pré-história da África Austral, Volume I), acreditam que os bantu sejam também os responsáveis pela introdução do pastoreio do gado na África Austral. Uma hipótese que se opõe aos dados linguísticos sobre a origem nordeste deste fato histórico, trazidos por Sutton e Ehret (Clark, 2010, p. 589). Por outro lado, o próprio Sutton fala em "sentimento de bantuidade", nos seguintes termos:

(...) ser bantu significava emigrar sempre, levando consigo um saco de sementes e algumas ferramentas para preparar o terreno e cultivar; fixar-se temporariamente em vez de se estabelecer definitivamente em povoados estáveis. Enfrentava-se o problema da população com maior migração interna, para áreas ainda não colonizadas. Por isto, o eixo da história é sempre o clã mais antigo, que primeiro colonizou a terra (Sutton, 2010b, p. 644).

Independente de tais exageros pontuais, de um modo geral, a $H G A$ reproduz uma explicação difusionista sólida da expansão banto, como o modelo mais adequado para a história da África subequatorial, até o inicio do segundo milênio d. $\mathrm{C}^{25}$.

Tal interpretação faz-se ainda mais pertinente quando se trata da história da África Meridional, desde o início da presente Era. Até esta data, a história da África Meridional, na $H G A$, é analisada de fato como uma pré-história da África. Tal fato é compreensível dada às dificuldades inerentes à reconstrução histórica de comunidades caçadoras-coletoras, com os san. Em relação aos khoi-khoi, J. E. Parkington,(África meridional: caçadores e coletores, Volume II) defende a hipótese que foram eles que teriam trazido, da África Oriental, a tradição do pastoreio dos carneiros e do gado bovino na região, no início da presente Era. Algo que complementa a tese já referida sobre a correlação entre migrações e pastoreio, na costa leste africana. Todavia, o próprio autor admite que tal fato não teria mudado, essencialmente, a história da região considerada. Sobretudo porque os khoi-khoi teriam mantido, na África Meridional, uma vida nômade, ainda arraigada à cultura de caça e coleta local (Parkington, 2010a, pp. 741-748).

\footnotetext{
${ }^{25}$ A única excessão é a Ilha de Magasacar. Isto porque, na $H G A$, a história dos principais povoamentos, assim como da formação das sociedades complexas na Ilha (pelo menos até o século XII) é vista como uma derivação da imigração dos austronesianos à região, advindos do Sul da Ásia, consular e insular. Sobre o assunto ver, em particular, B. Domenichini-Ramiaramanana. Madagascar (Volume III).
} 
Sendo assim, não resta dúvida de que, para a maioria dos autores da $H G A$, a história da África Meridional estaria necessariamente relacionada à chegada dos agricultores da Idade do Ferro à região, que teria ocorrido por volta do século IV da presente Era (Parkington, 2010a, p. 739). Na HGA, poucos duvidam que estes povos tenham sido os bantu. Aí estaria a origem das culturas neolíticas na região, que teriam formado os aldeamentos do norte da África Meridional, desde o século VII. T. N. Huffman, por exemplo, que estudará o assunto em A África Meridional ao Sul do Zambeze (Volume III), garante que se poderia atestar a origem bantu destes novos povoamentos. Isto, não apenas pela correlação entre Idade do Ferro e desenvolvimento agrícola, mas também pela suposta filiação continua no estilo da cerâmica, ali encontrada (Huffman, 2010, p. 781).

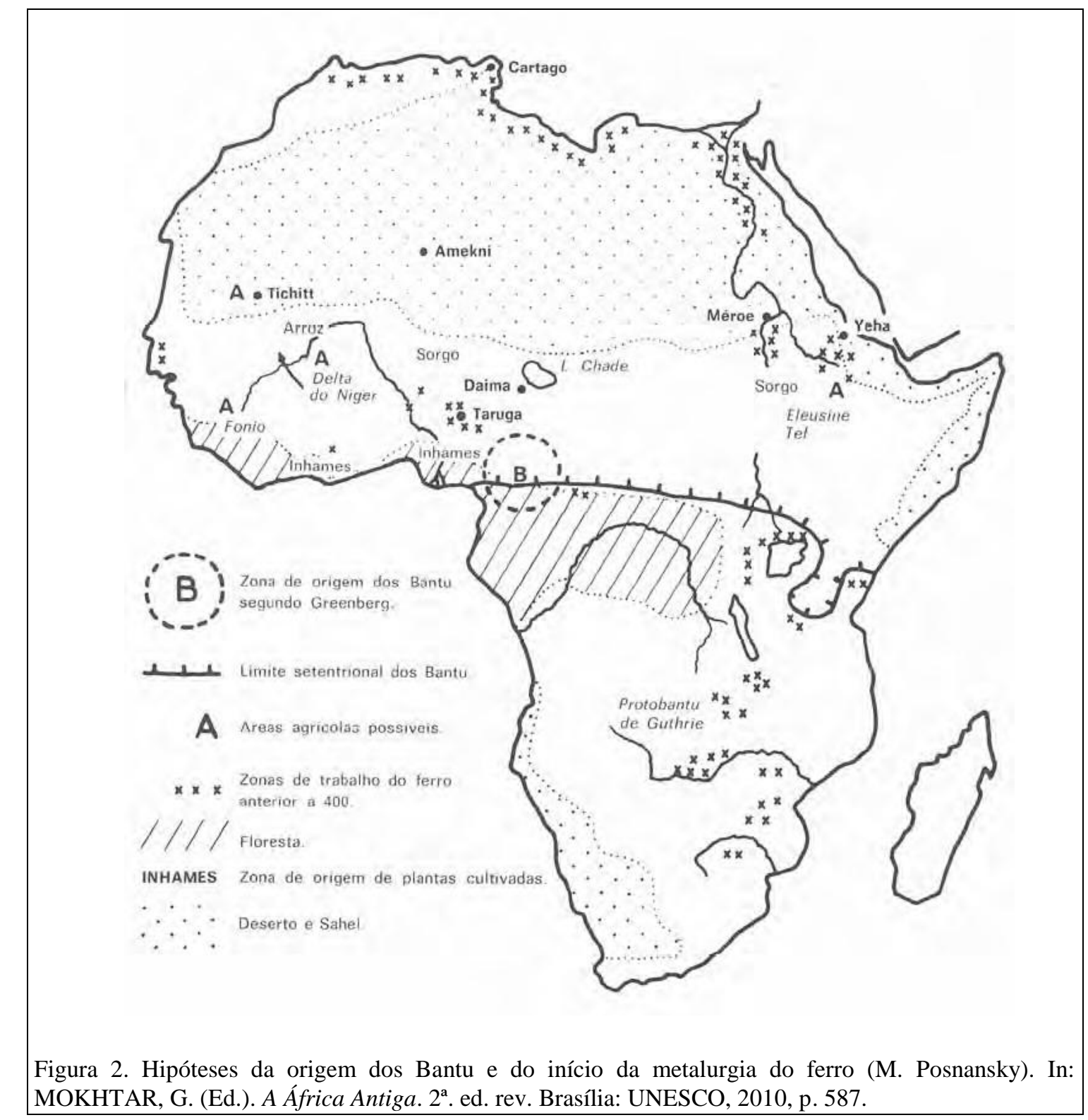


O terceiro e último ponto central acerca da explicação difusionista na história Antiga da África, na $H G A$, diz respeito ao suposto papel fundamental que o comércio internacional na Antiguidade - árabe, mediterrânico ou índico - teria tido na consolidação e desenvolvimento de certas sociedades complexas no continente, entre o último milênio a. C. e o século VI da presente Era. Se os autores da $H G A$ se rendessem a uma leitura externalista desta relação, como de fato alguns o fazem ${ }^{26}$, tratar-se-ia de explicar a existência destas sociedades como mero reflexo deste comércio internacional. Este não é este o caso da maioria dos autores da $H G A$. Mas para os difusionistas intraafricanos a situação é paradoxal. Afinal, ao mesmo tempo em que defendem a importância deste comércio internacional para o entendimento da África Antiga, cabelhes demonstrar o papel ativo que as sociedades africanas teriam tido nesta realidade histórica. Só assim poder-se-ia mostrar o caráter intra-africano, como aspecto central desta correlação entre comércio e sociedades complexas na África Antiga.

$\mathrm{Na} H G A$, isto é especialmente corrente nos estudos que tratam do papel ativo que certas sociedades africanas, especialmente no Norte e Nordeste do continente, teriam tido para a difusão do comércio na história do resto do continente. Em particular, na África sul-saariana.

Dada a anterioridade de relações históricas que egípcios e núbios mantiveram com o mundo não africano, pode-se imaginar que estes povos justificariam uma abordagem difusionista como esta, que trata da correlação entre comércio internacional e história da África Antiga. Não é esta, entretanto, a opinião corrente dos autores da $H G A$. Aqui faz-se necessário uma explicação desta problemática, antes de seguir adiante.

Como é sabido, a história das relações entre núbios e egípcios é antiga, remontando ao período Neolítico. Desde o inicio do segundo milênio a. C., o comércio parece ter sido um componente importante aí presente (Zayed, 2010, pp. 105-108; em colaboração com Devisse; Adam, 2010, p. 221; em colaboração com Vercoutter). Todavia, este comércio não era parte integrante do comércio internacional. Isto mudou, entrementes, com as subsequentes ocupações coloniais de povos não africanos no Egito

\footnotetext{
${ }^{26}$ Por exemplo, H. De Cotenson. A cultura pré-auxumita (Volume II); A. Sheriff. A costa da África Oriental e o comércio marítimo (Volume II).
} 
Faraônico, em particular, em sua região Baixa, no último milênio a. C. Desde então, como povos colonizados, os egípcios passaram a ter um papel intermediário entre a África e o comércio internacional afro-eurasiano, que se consolidou com a formação do Império Romano e do Império Chinês, nos últimos séculos a. C. No artigo O Egito na época helenística (Volume II), H. Riad (em colaboração com J. Devisse) mostra que este papel intermediário dos egípcios teria se consolidado durante a dominação ptolomaica, desde 300 a. C. A partir deste período, o Egito já aparecia como uma fonte de produtos africanos extremamente apreciados pelo comércio mundial, centrado no Oceano Índico, no Mar Vermelho e no Mediterrâneo - cujo extremo ocidental era Cartago. Neste comércio, os produtos africanos mais apreciados teriam sido o trigo (egípcio), ouro, marfim, especiarias, animais. Ademais, africanos escravizados eram comerciados. Sobretudo, a partir de Cartago e de Alexandria (Riad, 2010, pp. 165-168; em colaboração com J. Devisse).

Estes produtos exportados, assim como as pessoas escravizadas, não provinham apenas da costa do Norte da África. Pelo contrário, eram também fruto de relações comerciais e de exploração colonial, que os egípcios e os cartagineses mantiveram com populações africanas afastadas da costa mediterrânica do continente. No caso dos egípcios, por exemplo, mandatários locais e administradores gregos teriam sido responsáveis pelo estabelecimento de relações comerciais com a Núbia, a partir de Meroé. Quando os romanos tornaram-se soberanos do Egito, transformando-o em "celeiro do Império", também eles teriam negociado com os meroítas em 21 a. C. (ou 20 a. C.), acordos de paz visando manter tais intercâmbios (Leclant, 2010, p. 286). No caso do Império Cartaginês, sua riqueza, quase mítica, parece ter advindo da exploração de metais em estado bruto (ouro, prata, estanho), pedras preciosas, tráficos de pessoas escravizadas e produtos agrícolas (Warmington, 2010, p. 481). Este envolvimento da África no comércio internacional só aumentou quando o Império Romano colonizou a parte norte do Magreb, a partir do século I d. C.

Entretanto, a comprovação da existência destas relações comerciais na Antiguidade, não significa que elas tenham tido na realidade histórica uma importância fundamental para a história da África Antiga, desde a perspectiva africana ${ }^{27}$. Afinal,

\footnotetext{
${ }^{27}$ Ao menos que se interprete o Império Cartaginês como um produto da África e dos africanos, ao invés de vê-lo como uma colônia fenícia autônoma, com suas particularidades. Os autores da $H G A$ (e seus organizadores) estão com a segunda interpretação, que é a mais corrente.
} 
nenhum autor defende a ideia de que este comércio internacional tenha sido essencial para a construção de Meroé ou de outras cidades núbias (como Dongola ou Napata). Assim como, também, ninguém dúvida do caráter externalista que este comércio teve na história do Egito pós-Faraônico. É por isto que, ao tratar do comércio mundial, de acordo com a perspectiva africana, os autores que defendem uma visão difusionista intra-africana da África na $H G A$ deram ênfase a duas populações africanas que, mais do que os egípcios e núbios, integraram-se a este comércio internacional de maneira mais pró-ativa e essencialmente transformada da realidade local. Este seria o caso, por exemplo, dos auxumitas e dos garamantes.

Tanto os autores que analisam a "civilização dos garamantes", quanto aqueles que tratam do Império de Axum, defendem a ideia de que tais sociedades eram anteriores à sua integração neste comércio internacional afro-eurasiano da Antiguidade. Todavia, para estes, teria sido o posicionamento ativo destas sociedades nesta integração, que as teria transformado em sociedades mais ricas e articuladas.

No caso de Axum, vale destacar as contribuições neste sentido de F. Anfray ( $A$ civilização de Axum do século I ao século VII) e Y. Kobishanov (Axum do século I ao IV: economia, sistema político e cultura). Nestes artigos, os autores buscam evidenciar a correlação entre a civilização de Axum e o desenvolvimento do comércio internacional afro-eurasiano, durante o primeiro milênio da presente Era. Três fatos são relevantes nesta demonstração. O primeiro é a centralidade que as cidades de Axum e Adulis (e seu porto), teriam tido para a sociedade auxumita em geral. Um bom exemplo disto é uma fonte documental datada de $525 \mathrm{~d}$. C, informando que haveria em Gabaza (porto de Axum), naquele momento, 64 navios de nacionalidades diferentes: egípcios, romanos, hindus, farasianos (sul-arábicos) etc. Ademais, destas cidades também sairiam as rotas de caravanas para o Vale do Nilo (Kobishanov, 2010, p. 410). O segundo fato relevante é que, ainda no século III, Axum já cunhava a sua própria moeda, visando controlar os intercâmbios internacionais. Finalmente, vê-se as disputas e guerras diplomáticas de Axum com os grupos árabes, pelo controle do comércio do Mar Vermelho (Anfray, 2010, p. 396; Kobishanov, 2010, pp. 405-410).

O mesmo tipo de abordagem busca provar o papel ativo que os povos magrebianos, em especial, os garamantes, teriam tido durante o período histórico que vai do fim da última Era até o século VI da presente Era. 
Não resta dúvida aos autores que tratam da temática, que os povos magrebianos já possuíam agrupamentos organizados, antes do domínio cartaginês (VI-146 a. C) e romano (146 a. C- V d. C). Seriam povoamentos derivados da evolução das culturas neolíticas da região, sendo cultural e biologicamente fruto de populações africanas e outras mediterrânicas antigas, árabes e europeias. Em particular, na costa mediterrânica do continente, em que o peso dos povoamentos externos seria marcante. Daí o caráter misto de populações etnicamente distintas que chamamos de líbios antigos (tehenu, temehu e outras), contemporâneos das primeiras dinastias faraônicas no Egito. Segundo J. Desanges (Os proto-berberes, Volume II), tal proximidade com o mundo mediterrânico teria se reforçado pelo inicio da navegação do estreito de Gibraltar (IV milênio a. C) e pelo ressecamento do Saara. A ocupação cartaginesa seria, portanto, um elemento tardio desta história mediterrânica, em que a costa norte-africana e o Egito estariam integrados há milênios (Desanges, 2010, pp. 454-460).

Se os autores que tratam da temática, como J. Desanges, se ocupassem apenas de comprovar esta relação mediterrânica das populações magrebianas antigas, poder-se-ia imputar-lhes uma percepção externalista da história da África. Todavia, na medida em que estes destacam a contribuição egípcia e autóctone para o desenvolvimento de sociedades organizadas entre tais populações, seria mais correto ver aí um espectro do difusionismo intra-africano. Tal interpretação é crível porque, para estes, os elementos para a vida sedentária, no Magreb, seriam de origem nativa ou egípcia, antes do que dos "Povos do Mar" ou dos fenícios. Por exemplo: a) a agricultura, com arado de ferro; b) instalações hidráulicas primitivas; c) criação de ovinos, caprinos e gado; d) cerâmica; e) utilização de carros de madeira, puxados por cavalos (Desanges, 2010, pp. 464-467).

É esta civilização proto-berbere, que também herdaria características cartaginesas da costa mediterrânica que, segundo autores como P. Salama (O Saara durante a Antiguidade Clássica, Volume II), teria dado origem ao Reino dos Garamantes, tido como o principal reino berbere da Antiguidade. Este reino, a partir da cidade de Germa, no Saara central, teria exercido sua dominação por toda a região do Fezzan, entre os séculos II (a. C) e VII (d. C) (Salama, 2010b, p. 571).

Para Salama, o Reino dos Garamantes teria tido um papel fundamental na difusão do comércio no Magreb antigo, entre os séculos II e V (d. C), embora se tratasse de uma sociedade dependente da ocupação romana da costa subsaariana. Outros reinos 
berberes teriam aí tido também sua importância histórica, como o Numída e o Nasamone. Mas o Garamante teria sido o fundamental. Tal centralidade derivaria de três fatores, segundo Salama. Em primeiro lugar, os garamantes teriam se tornado os principais fornecedores da demanda romana por animais selvagens, que estariam desaparecendo da África do Norte, como elefantes, leões, tigres, avestruzes, antílopes. Este interesse teria correspondido à parte mais significativa do comércio saariano, que também poderia envolver escravos e ouro. Secundariamente, os garamantes teriam se beneficiado da posição privilegiada de Garama na rota mais acessível entre sul e norte do deserto, desembocando nas cidades comerciais costeiras do Mediterrâneo, como Leptis Magna e Sabrata. Também dali poder-se-ia chegar, por uma rota setentrional, ao Vale do Nilo. Finalmente, a tecnologia de transportes dos berberes daquela região, que incluía a utilização de carruagens com cavalos e os camelos (no início da presente Era), teriam revolucionado a ocupação do deserto (Salama, 2010b, pp. 276-283).

A posição de Salama sobre o assunto é tipicamente difusionista intra-africana. A “civilização garamante", diz o autor, era dependente do comércio romano. Mas isto não faz dos garamantes meros reprodutores do externalismo. Pelo contrário, a influência e as transformações impulsionadas pelos garamantes fariam parte de uma história interna da África, difundidas por esta população em particular. Em suas palavras:

A área de dispersão dessas provas - moeda romana em rota saariana mostra que a civilização garamante, dependente das relações com Roma, estendeu sua influência a centenas de quilômetros. Convém salientar que tal influência era inteiramente garamante e não romana, embora constituísse um foco secundário de dispersão de objetos romanos. É aqui que a personalidade saariana antiga se afirma com maior veemência: as populações locais mantinham relações bastante estreitas, qualquer que tenha sido a causa inicial de sua aproximação muito provavelmente, a busca de mercadorias destinadas ao comércio com Roma (Salama, 2010b, p. 578).

Um dos exemplos dados por Salama da suposta importância deste comércio saariano e do "fator garamante" para a história da África Antiga é a introdução do ferro na África subsaariana. Colocando-se contra as posições externalistas - segundo as quais o ferro teria chegado à África subsaariana pelo Saara Central - com os fenícios- e regionalistas - segundo a qual a produção do ferro teria sido autóctone à região -, o 
autor defende a ideia de que este teria sido introduzido na África subsaariana pelas rotas do Saara oriental, controladas pelos garamantes e seus satélites (Salama, 2010b, pp. 578-579).

O destaque dado por P. Salama ao Reino dos Garamantes justifica sua presença como uma das teses centrais da explicação difusionista intra-africana da história da África, durante o período considerado. Afinal, ela reinterpreta o papel do Magreb na Antiguidade. Os próprios organizadores da obra recomendam mais estudos sobre o assunto, como pode-se atestar da seguinte nota de rodapé:

Nota do Comitê Científico Internacional: Na próxima edição, pretende-se fazer um relato mais preciso do legado e do papel da Líbia durante o período abordado neste volume. Está previsto um simpósio que tratara da contribuição da Líbia na Antiguidade clássica, com referencia especial ao papel da Cirenaica durante o período helenístico, da Líbia no período fenício e da civilização dos Garamantes (Desanges, 2010, p. 500)

É interessante observar que esta promessa de retomar a temática magrebiana na Antiguidade, nos próximos volumes ou edições da $H G A$ não será realizada, conforme aí prometido pelos organizadores. Evidentemente, várias são as hipóteses para pensar porque isto teria ocorrido. A partir da análise aqui realizada, todavia, observa-se que o abandono desta correlação entre comércio na Antiguidade (pré-muçulmano) e o desenvolvimento das sociedades complexas na África, nos demais volumes da $H G A$, se deve ao fortalecimento da importância de outras duas visões sobre o assunto, predominantes no Volume III da obra. A primeira delas é a interpretação externalista da história da África. Para os historiadores desta linha, não caberia buscar as origens das sociedades complexas, na África Ocidental e Oriental, no comércio internacional na Antiguidade. Mas como fruto da chegada dos muçulmanos na África, a partir do século VII. A segunda é a visão regionalista. Para aos historiadores desta linha, a formação das sociedades complexas deveriam ser buscadas em sua evolução local, e não no comércio internacional. No quarto capítulo se abordará tal interpretação. Por enquanto, cabe continuar a análise da explicação difusionista intra-africana da história da África, a partir do século VII. 


\subsection{A África entre os séculos VII e XVI}

Desde um ponto de vista difusionista intra-africano, a expansão do Islamismo na África é um ponto central da história africana, entre os séculos VII e XVI. Isto ocorre, porque segundo os autores que defendem tal interpretação histórica na $H G A$, a religião islâmica e o complexo cultural do qual ela faria parte teriam sido fatores importantes para a consolidação e evolução das sociedades complexas no continente africano.

A certeza sobre este assunto é tão ampla no terceiro volume da $H G A$, que alguns autores passam ali a fronteira do difusionismo intra-africano para o externalismo islamocêntrico. Este é o caso do editor (M. El Fasi) e dos autores responsáveis pelos primeiros capítulos $(1,2,4,7,9,10,12)$ do referido volume. Nestes artigos, prevalece a ideia do papel civilizador do Islã sobre os povos africanos. Daí o próprio editor do volume qualificar de "selvagem" a resistência berbere ao avanço muçulmano no Magreb (Fasi, 2010a, p. 75).

Mas há também neste volume posicionamentos mais sóbrios sobre o assunto, concomitantemente mais de acordo com os princípios da $H G A$ de construir uma história da África por ela mesma. O principal destes argumentos poder-se-ia chamar de "Islamismo de corte", tratado, por exemplo, por I. Hrbek em A difusão do Islã na África, ao Sul do Saara (Volume III). Hrbek traz para a $H G A$ a tese de que a adoção da religião islâmica pelos soberanos da África Sudanesa teria sido motivada por esta ser uma religião de caráter universal, num momento histórico de consolidação dos reinos africanos na região. Ou seja, o Islã teria surgido como uma solução possível, ideológica, para assegurar a fidelidade das etnias e clãs politeístas, que estes soberanos haviam dominado e cujos cultos ancestrais diferiam daqueles das dinastias reinantes. Assim, para tais soberanos, a adesão ao Islã de forma híbrida, junto aos chefes de outras linhagens e clãs, objetivava fazer nascer entre eles um novo laço religioso. Por outro lado, diz o autor, dada a extensão dos seus impérios, a presença de escribas e de outras pessoas instruídas na cultura islâmica, teria sido importante na administração eficaz do seu território e no funcionamento do correio e dos assuntos do Estado. Com isto, os religiosos muçulmanos teriam exercido grande influência nas cortes reais, abrindo a via para a posterior conversão do soberano e da sua família (Hrbek, 2010b, p. 94). 
Além do Islamismo, outro fator que é retomado a partir da visão difusionista da história da África, entre os séculos VII e XVI é, novamente, a correlação entre este comércio internacional afro-eurasiano e consolidação de sociedades complexas na África. A partir da perspectiva africana, esta abordagem será utilizada para explicar dois fenômenos históricos importantes da história da África, neste período: a) o desenvolvimento das relações comerciais entre África Setentrional e África ocidental (sub-saariana); b) a expansão da civilização swahili, na costa leste do continente.

Umas das explicações mais coerentes desta primeira temática na $H G A$ está nos artigos de J. Devisse, especialmente em Comércio e rotas do tráfico na África Ocidental (Volume III). Não por acaso, ele será co-autor de outros três artigos, nos Volumes III e IV da obra: Os almorávidas (em co-autoria com I. Hrbek, Volume III), A África do século VII ao XI (em co-autoria com Vansina, Volume III) e A África nas relações intercontinentais (em co-autoria com Labib, Volume IV).

O argumento central de Devisse é que a história das relações entre os povos africanos na África Setentrional e na África Ocidental, entre os séculos VII e XVI, deveria ser entendida como parte integrante das relações econômicas do mundo mediterrânico, polarizado entre muçulmanos e europeus. A razão primordial para este fato, segundo o autor, seria a qualidade do ouro sudanês, algo que ele busca comprovar a partir das fontes primárias árabes e de análises laboratoriais, realizadas nos anos 1980. Devisse não desconsidera outros produtos e mercadorias que circulavam nesta vasta região na direção sul-norte ou norte-sul (animais, sal, escravos, cerâmica, vidros, tecidos, couro etc), nem o comércio africano pré-existente (sal, cobre, ferro etc), mas acredita que foi a busca pelo ouro sudanês, o fator responsável pela instauração das caravanas (com a utilização massiva dos dromedários e carregadores) no comércio transsariano, que teria mudado a face deste comércio, a partir do século X (Devisse, 2010b, pp. 448-450).

Evidentemente, outros lugares em África teriam sido fontes de ouro do comércio internacional, como a Núbia e o Zimbabwe. Todavia, este desejo pelo ouro sudanês, segundo Devisse, se justificaria tanto por razões econômicas, quanto políticas, derivadas da luta pela hegemonia dentro e fora do mundo muçulmano da época. Isto porque, por ser de excelente qualidade, o ouro sudanês proporcionaria, além de riqueza material, credibilidade às moedas imperiais das dinastias muçulmanas (umayyade, fatímida, almorávida, almoáda, hafessida) que o tinham por matéria-prima (Devisse, 2010b, p. 
462). A figura abaixo mostra os principais pontos desse comércio transaariano, entre os séculos IX e XI, segundo Devisse:

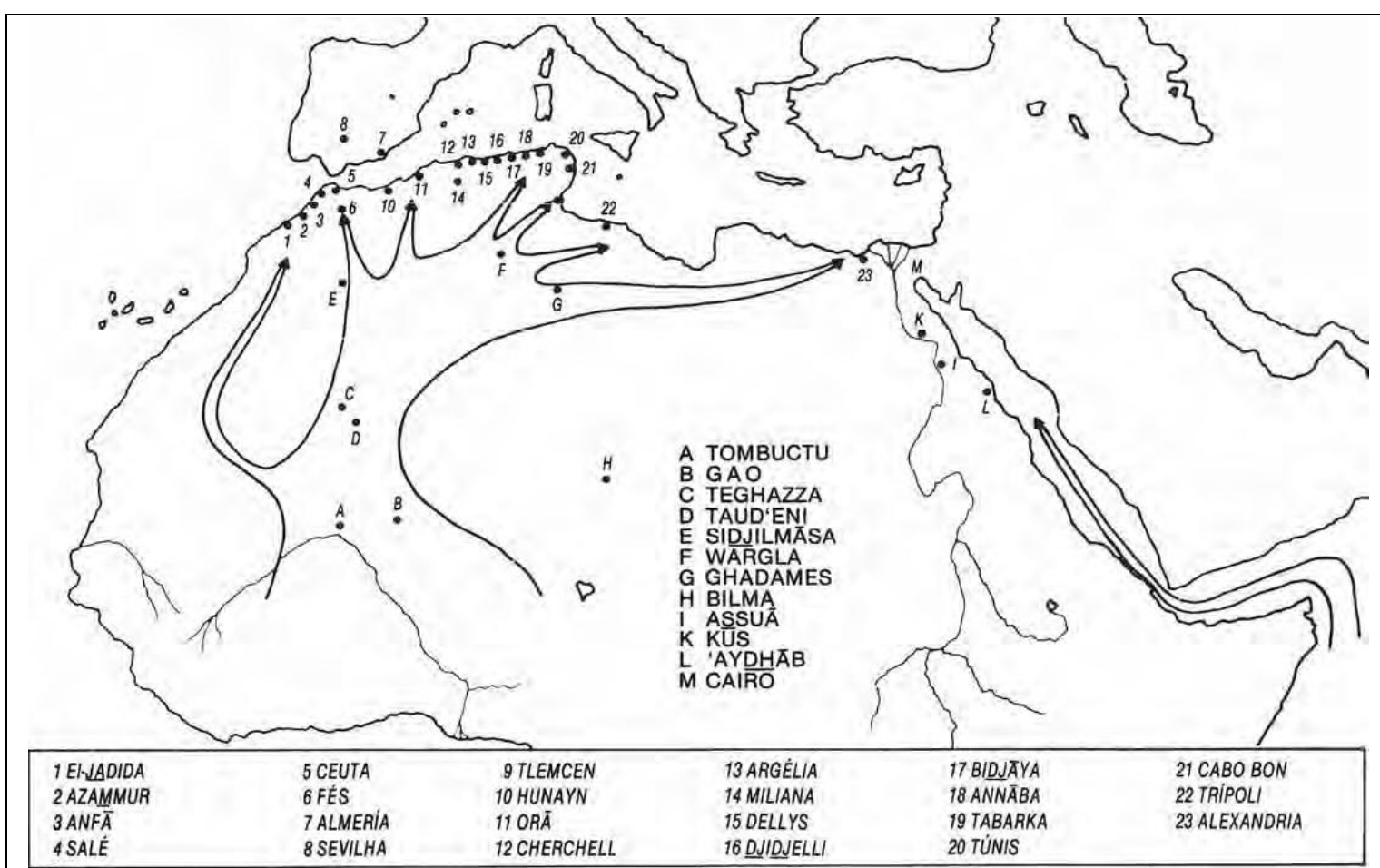

Figura 3. Mapa do fluxo do ouro africano na economia muçulmana da África setentrional. (J. Devisse). In: NIANE, D. T. (Ed.). A África do século XII ao XIV. São Paulo: Brasília, 2010, p. 733.

A tese de Devisse, portanto, é que a qualidade do ouro sudanês seria o elemento essencial da dinâmica histórica da África Setentrional e Ocidental, especialmente entre os séculos IX e XVI. O caráter difusionista intra-africano desta tese só fica evidente tendo em conta que, para o autor, tanto o Magreb muçulmano, quanto os povos extratores do ouro (na África Ocidental) fariam parte de uma mesma rede comercial, cujo elemento essencial (ouro sudanês) e os participantes diretos seriam parte do contexto africano. Esta é a interpretação que diferencia, ainda que sutilmente, a tese de Devisse daquelas externalistas, para quem o comércio transaariano, controlado pelos árabes-muçulmanos, teria sido o responsável pela formação dos reinos sudânicos. $\mathrm{O}$ próprio autor destaca este fato, nas seguintes palavras:

Todas as recentes pesquisas reequilibram profundamente a história dosintercâmbios técnicos e comerciais: graças a elas, deixou-se de fazer da África do Oeste uma dependência do Norte, intermediada pelas relações transaarianas. Aqui reconduzido às suas devidas proporções cronológicas e quantitativas, o comércio transaariano 
cessa, todavia, de encerrar considerável interesse. As transformações que ele introduziu, em todas as regiões a Sul e Norte do deserto, poderão ser doravante medidas com maior inédita sabedoria (Devisse, 2010b, p. 487).

Outra forma difusionista intra-africana de destacar esta importância do comércio internacional na história da África, entre os séculos VII e XVI, sem recair nas posições externalistas, será adotada por autores que defendem a intima relação entre Islamismo e redes comerciais africanas, neste período histórico. Para estes, esta correlação estava fundamentada no fato de que o Islamismo teria sido um fator unificador entre grupos comerciantes berberes e sudaneses, na consolidação das rotas transaarianas. Sobretudo, porque ele teria trazido o elo de confiança e os códigos morais que facilitavam tais transações comerciais. Entres os sudaneses, destaca-se o papel ativo que os "wangara", e posteriormente, os "dioula" 28 , teriam tido, por isto, na expansão do mundo muçulmano, em sua face religiosa e econômica, na África Sudanesa (Hrbek, 2010b, p. $88)$.

$\mathrm{Na}$ mesma perspectiva de análise da correlação entre comércio mundialsociedades africanas está o artigo de V. Matveiev: $O$ desenvolvimento da civilização swahili (Volume IV). Defende este autor que o comércio internacional teria sido, de fato, o elementos dinamizador da história swahili, entre os séculos XIII e XV. No entanto, a importância deste fator só poderia ser bem compreendida, tendo em conta que ele tornou-se fundamental por potencializar um conflito de classes pré-existente, em tal civilização. Neste, se confrontariam a antiga nobreza local e a nova elite mercantil, associada ao comércio internacional, a vida urbana e a religião muçulmana (Matveiev, 2010, p. 525). Infelizmente o autor traz poucos elementos para embasar sua tese, mas há aí uma perspectiva metodológica sólida para uma visão difusionista da história da África. Nesta, o fator externo potencializaria o interno, que seria de fato o essencial ${ }^{29}$.

\footnotetext{
${ }^{28}$ Ver nota 27.

${ }^{29}$ Uma tese aproximada à de Matveiev é exposta, de forma generalista, por A. Bathily \& C. Meilassoux (As relações entre as diferentes regiões da África, Volume III). Ela diz, em suma, que o comércio apenas potencializou a luta de classes interna, das sociedades africanas. No entanto, neste caso, os exemplos e fundamentações dos autores não atestam tal hipótese. Pelo contrário, ratificam uma visão externalista do continente. Aí, os fatores internos são, em verdade, tidos como secundários diante dos externos, advindos da expansão muçulmana.
} 
Entretanto, este fator interno - africano - é melhor atestado na visão difusionista, nos artigos que enfatizam o papel de povos específicos, como os mande (mandenka, mandingo, “wangara”, “jula” ou dioula ${ }^{30}$ ), na história da África deste período. D. T. Niane e Y. Person tratam do tema no Volume IV, respectivamente, em O Mali e a segunda expansão Mande e Os povos da costa - primeiros contatos com os portugueses - de Casamance às lagunas da costa do Marfim.

No primeiro artigo citado, Niane defende que duas expansões de grupos mande teriam sido responsáveis pela constituição e força comercial das sociedades de Gana, Djeneé e Mali, na África Ocidental, entre os séculos VIII e XV. O segundo aspecto nos interessa mais do que o primeiro, neste momento. Para Niane, os mande teriam adquirido esta experiência comercial de suas atividades nas redes de intercâmbios locais e saarianas, que já estariam em funcionamento desde o século V (d. C). Para comprovar esta rota saarina antiga, Niane assegura que os objetos de cobre encontrados no sítio de Djenne-Djeno (curva do Níger), só poderiam advir da mina de Takkeda, no Saara. Por esta razão primordial, o autor acredita que os árabes muçulmanos tenham apenas ampliado esta rede comercial, pré-existente ${ }^{31}$. Algo para o qual os mande, islamizados ou não, também teriam tido um papel essencial (Niane: 2010b, pp. 134-135; Niane, 2010c, p. 709).

Esta importância comercial dos mande é também tema de Y. Person, no artigo citado. Ali, Person vê nas expansões mande o fator primordial de consolidação de uma extensa rede comercial a partir do século XIII, do Sahel até a costa atlântica. Esta seria movida por produtos locais e norte-africanos, sendo os mande o grupo intermediário deste comércio de longa distância. Ademais, o autor atribui a tais povos um papel

\footnotetext{
${ }^{30}$ Reporto a explicação de D. T. Niane:

A palavra Wangara (que os franceses escrevem Ouangara) é utilizada pelos Fulbe (Peul) e Haussa (Hawsa) para designar os Manden (ou Mandingo). Wangara e Wakore tem a mesma origem, embora Wakore se aplique mais especificamente aos Soninke (ou Sarakolle). Na floresta da Costa do Marfim, os Manden (Mandingo) são conhecidos como Jula (ou Diula), que significa comerciante, em língua malinke. Wangara e Jula (Diula) são sinônimos e indicam, mais particularmente, os Manden (Mandingo) que se dedicam ao comércio (Niane, 2010b, p. 133).
}

\footnotetext{
${ }^{31}$ Também T. Shaw, no artigo A zona guineana (Volume III) levanta a hipótese deste comércio antigo saariano-sudânes (pré-muçulmano), supostamente baseado em escravos e no ouro, ter sido um fator determinante da formação das sociedades complexas na região sudanesa, como atestariam os vestígios de Kumbi-Saleh e os megalíticos da Senegâmbia (Shaw, 2010b, p. 549). No entanto, além de tratar o assunto como hipótese ainda a ser provada, ele não relaciona tal comércio a um grupo populacional específico, como o faz Niane.
} 
essencial na difusão das instituições políticas centralizadas, nas margens da floresta equatorial (Person, 2010, p. 354).

Para Niane e Person, portanto, não resta dúvida, quanto ao papel fundamental que as expansões mande, das savanas para as florestas oeste-africanas, teriam tido na consolidação ou mesmo formação de sociedades complexas na África Ocidental. Eles não seriam apenas intermediários de um comércio maior, extra-africano. Seriam os povos que, de fato, controlavam esta rede comercial no Sahel e na região sudanesa. Daí sua suposta centralidade para o desenvolvimento das sociedades complexas na região, que teriam se potencializado com a formação do comércio transaariano, a partir do século X. Neste particular, cabe integrar tal interpretação dos autores à visão difusionista da perspectiva africana.

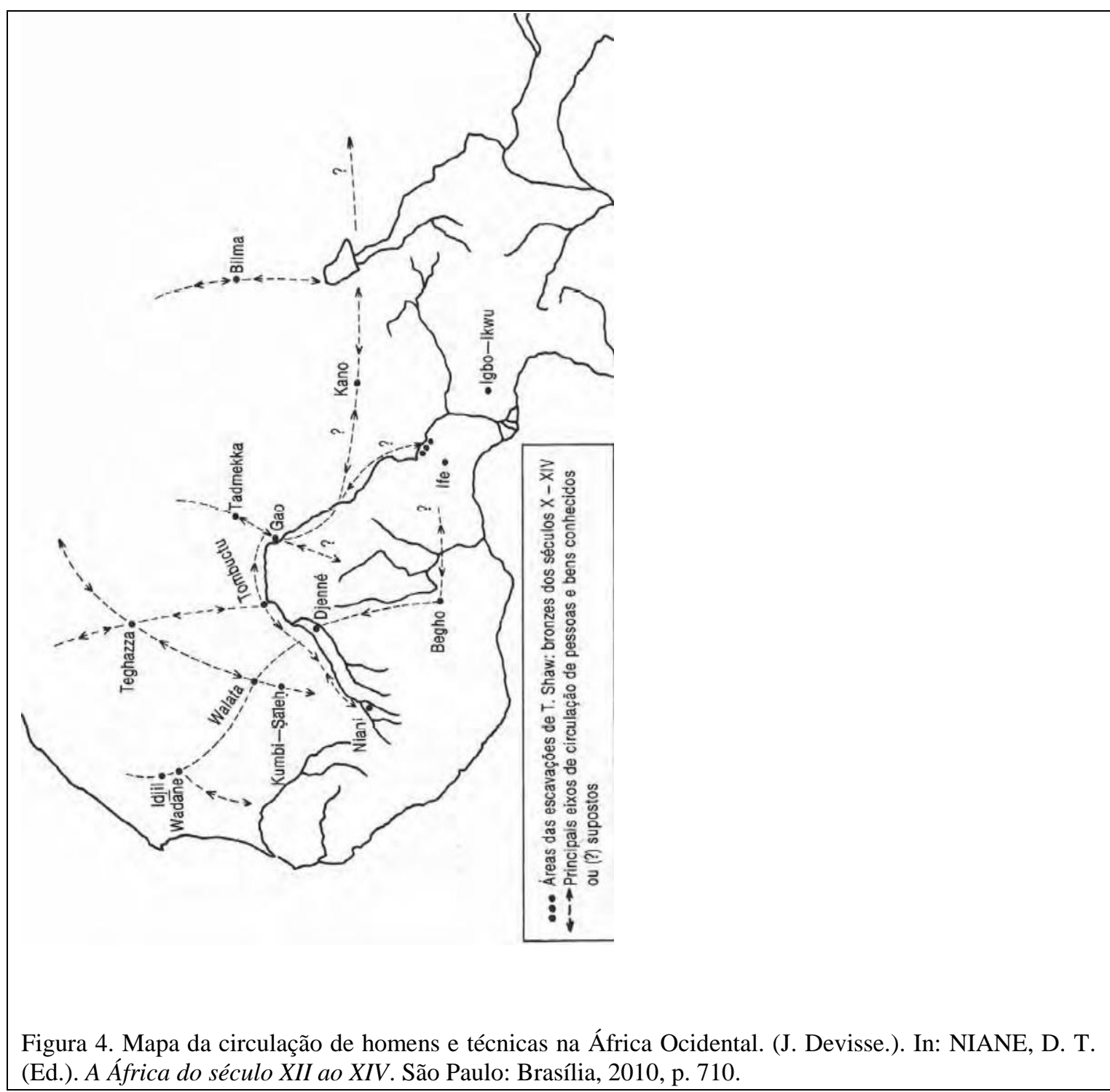


A questão das migrações populacionais continua, também, a ser central nesta visão do difusionismo intra-africano na história da África, entre os séculos VII e XIV. Isto fica evidente quando certos autores da $H G A$ tratarem, novamente, dos povos bantu e dos khoi-khoi, na África Austral.

Em relação à expansão bantu, esta história continua sendo uma história difusionista apenas quando referida ao período histórico entre os séculos VII e XI. Dois exemplos interessantes desta explicação estão em D. Phillipson (A África Central ao Norte do Zambeze, Volume III) e T. Huffman (A África Meridional ao Sul do Zambeze, Volume III).

No primeiro artigo, relacionando os dados linguísticos e arqueológicos sobretudo os derivados do estudo das cerâmicas e da tecnologia do ferro -, Phillipson diz ser evidente que a expansões migratórias ocidentais e orientais da África Central, desde o início da presente Era, seriam derivadas do grupo bantu, com suas diversas distinções regionais. Na África Central, Phillipson diz que os primeiros aldeamentos fixos da região teriam sido datados do século $\mathrm{V}$ - embora o autor admita que poderiam existir outros mais antigos. Tanto na parte oriental, quanto na ocidental, segundo o autor, seriam agrupamentos agrícolas situados nas orlas dos rios, em que o trabalho de cobre parece ter sido importante elemento de comércio regional. Apesar disto, o autor acredita que não havia ainda, nestas sociedades, uma hierarquia social considerável. Tal fato só passaria a existir no fim do primeiro milênio, na região do alto Lualaba. Aí poder-se-ia observar um aumento sensível da riqueza, da atividade comercial e da densidade de população (Phillipson, 2010, p. 777).

Também partindo da ligação Linguística-Arqueologia, T. Huffman assegura que se pode relacionar a formação de comunidades complexas, na região do Zambeze e do Limpopo, a partir do século VII, com a fixação de povos bantu advindos da África Central. Em especial, os grupos Zhizo (século VII), Leopard’s Kopje (século XI) e outros aparentados, como os Gumaye e os Toutswe (Huffman, 2010, pp. 781-783). Todavia, sua interpretação difere da de Phillipson, em relação à importância que ele atribui à cultura pastoril e de cereais, que seria específica destes povoamentos bantu. Para Huffman, o trabalho arqueológico nas aldeias de Schroda (século IX) e K2 (século X) - localizadas na fronteira entre Zimbabawe, Botsuana e Moçambique demonstrariam o fato de que o pastoreio ocuparia, ali, uma centralidade espacial, 
simbólica e econômica muito maior do que se acreditava. Para o autor, esta seria uma característica particular dos bantu meridionais, como os Shona, cujos ancestrais seriam originalmente Zhizo, Leopard's Kopje e outros (Huffman, 2010, pp. 787-790).

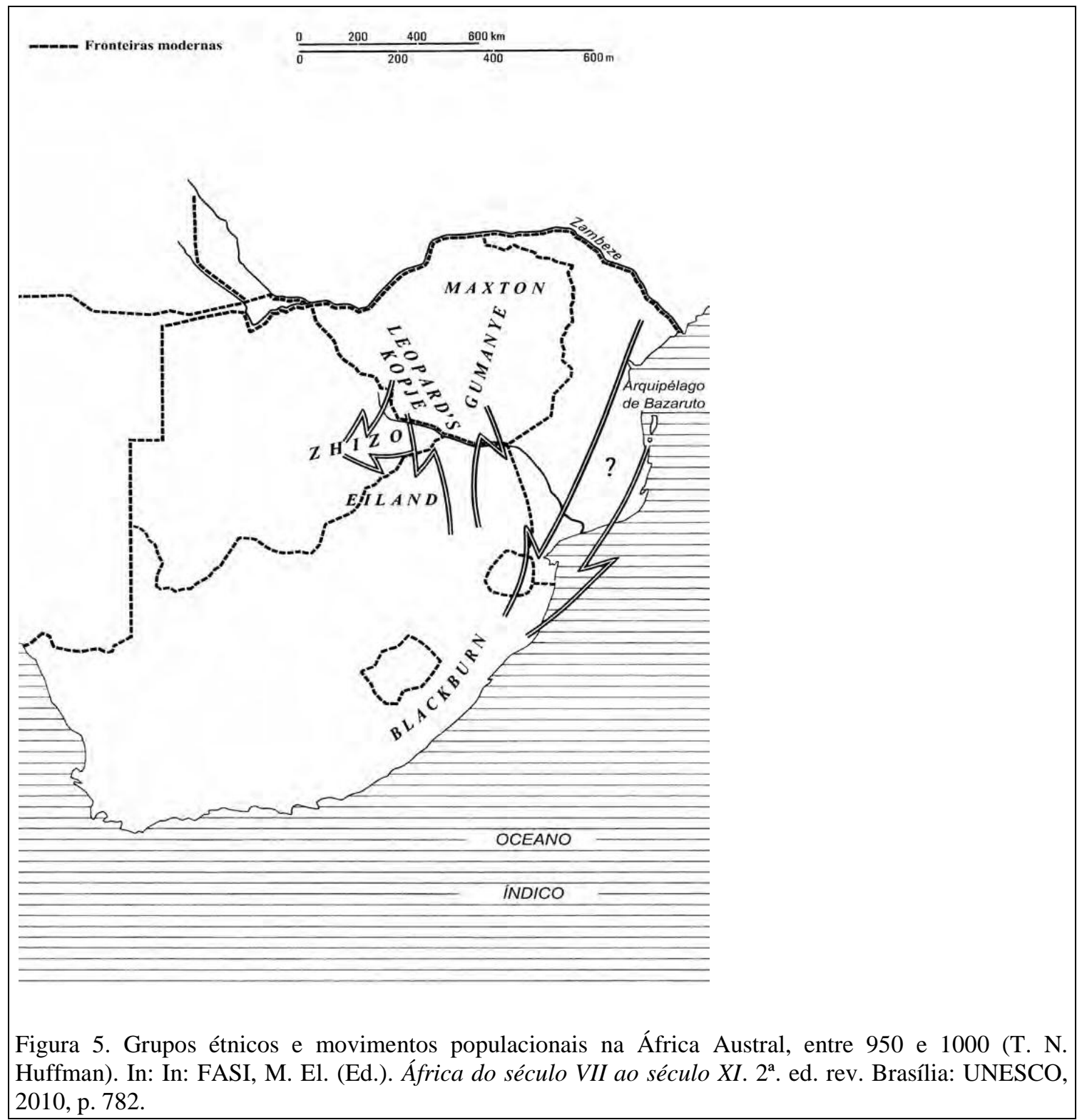

Huffman acredita que o comércio internacional tenha tido um papel considerável no desenvolvimento destas sociedades africanas, a partir do século IX. Baseando-se em provas arqueológicas, o autor defende que isto ocorreria porque a presença de produtos provindos deste comércio internacional, como cerâmicas, contas de vidro, tecidos e perolas, seriam utilizados nestas sociedades tradicionais, para aumentar a potência política dos chefes locais. Daí que, quanto maior o poder do chefe, maior seria também o seu distanciamento espacial e simbólico da população local. Algo que seria 
perceptível na separação espacial entre elite e governados no povoamento de Mapungubwe, após K2 ter sido abandonada, em fins do século XI. Ao institucionalizar esta estrutura de classe, demarcada por muros de pedra e espaços delimitados, o autor acredita que Mapungubwe fosse representativa de uma nova cultura e elite local, que teria dado origem ao Grande Zimbabwe, no século XIII (Huffman, 2010, p. 791). A figura abaixo ajuda a localizar algumas das regiões e sítios citados:

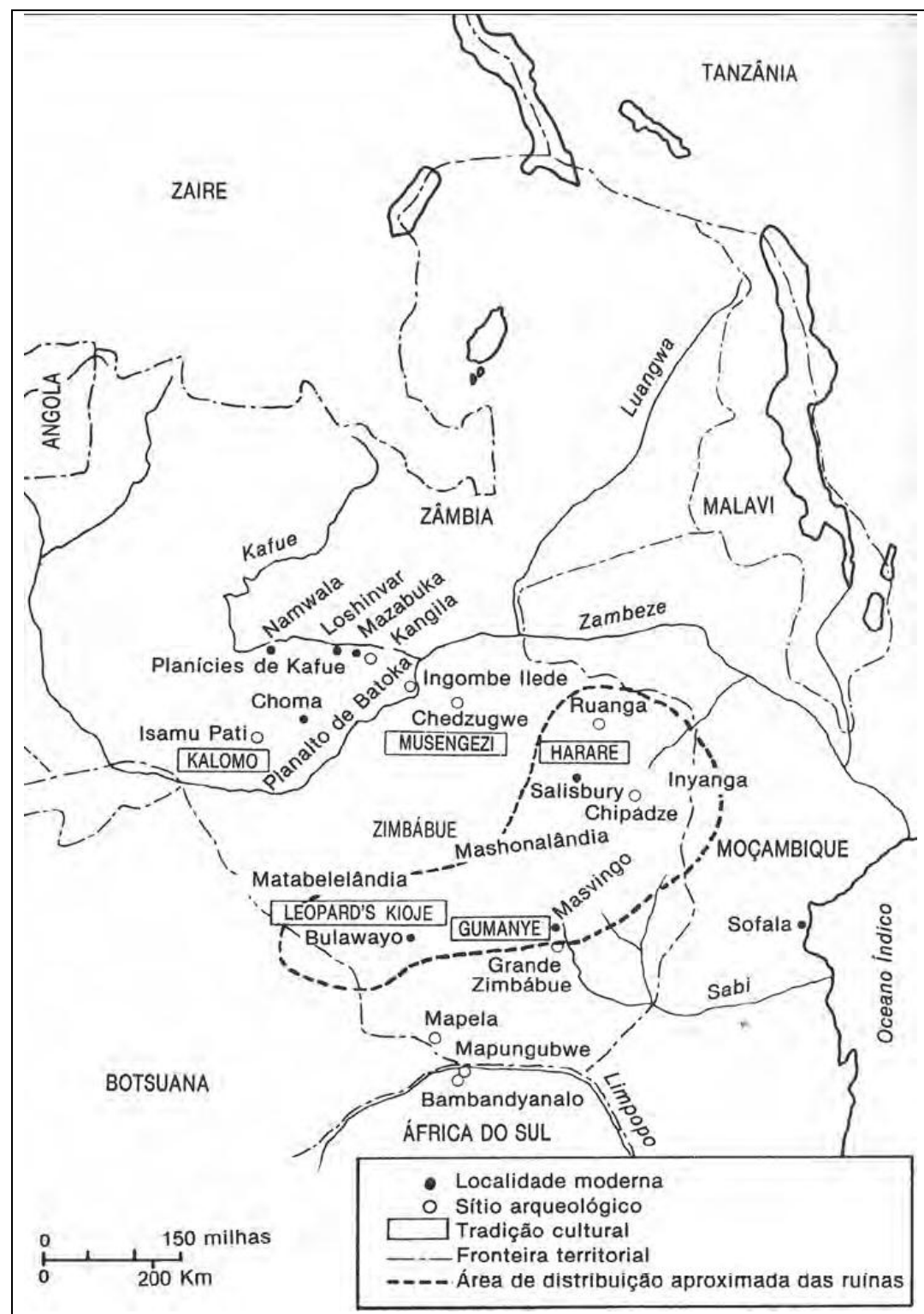

Figura 6. Mapa dos sítos e tradições arqueológicas mencionadas no texto (B. Fagan). In: NIANE, D. T. (Ed.). A África do século XII ao XIV. São Paulo: Brasília, 2010, p. 592.

É interessante notar que, neste estudo, Huffman sintetiza duas crenças básicas da explicação difusionista da história da África: migrações bantu e comércio internacional. 
Neste caso, o primeiro fato parece ser fundamental para o segundo. É porque os bantu se fixaram na região, com sua cultura pastoril, que teria ocorrido a forte integração da África Meridional neste comércio. Em suma, trata-se de uma visão histórica que interrelaciona: bantu - sociedades complexas - comércio internacional.

Sem ater-se ao último item desta visão, B. Ogot, no artigo A região dos Grandes Lagos (Volume IV) estabelece a ligação entre bantu e sociedades complexas, como um objetivo do seu estudo. Criticando a visão camita da história da região, para quem os primeiros Estados da região dos Grandes Lagos seriam advindos de migrações de pastores vindos do nordeste africano, Ogot acredita que foram os bantu os responsáveis pela formação dos reinos lá localizados, por volta do século XIII. Baseando-se nos estudos de outros historiadores e na tradição oral, este autor afirma que tais sociedades seriam fruto do amadurecimento de comunidades de clãs de origem bantu, que teriam chegado à região no século $\mathrm{X}$. Este seria o caso do clã Batembuzi, que teria formado o primeiro Estado da região no século XV; hoje chamado de complexo de Kitara. Para o autor, quando as novas migrações de pastores chegaram aos Grandes Lagos, por volta do século XV, portanto, lá já existiriam sociedades agrárias complexas (Ogot, 2010b, pp. 561-562).

Se Phillipson, Huffman e Ogot são os autores que enfatizam a expansão bantu, como fator essencial para a formação das sociedades complexas na África Austral, durante os séculos VII e XVI, outros autores vão estender tal interpretação à expansão dos povos khoi-khoi, no mesmo período histórico.

Esta perspectiva é defendida por L. D. Ngcongco em A África Meridional: os povos e as formações sociais (Volume IV; em colaboração com Vansina). Para estes autores, a constituição de uma cultura pastoril na África Meridional, em meados do século XIII, especialmente entre os Ngugi, não seria baseada na tradição dos povos bantu ou centro-sudânica. Ela seria de origem khoi-khoi, que teriam chegado à esta região advindos de Botsuana, na África Central, um século antes. Nestas comunidades originais, formadas entre os séculos VIII e XIII, ter-se-ia apreendido a forjar metais (mas não a fundi-los) e a viver coletivamente de forma hierarquizada. Aí, os khoi-khoi, portanto, já teriam abandonado parcialmente seu modo de vida baseado na caça e na coleta. Iniciada a expansão norte-sul, os khoi-khoi teriam difundido sua língua, tipo 
biológico e gado específico (de raça Afrikander), para outros povos com que conviveram, até a África Meridional (Ngcongco, 2010a, pp. 672-677).

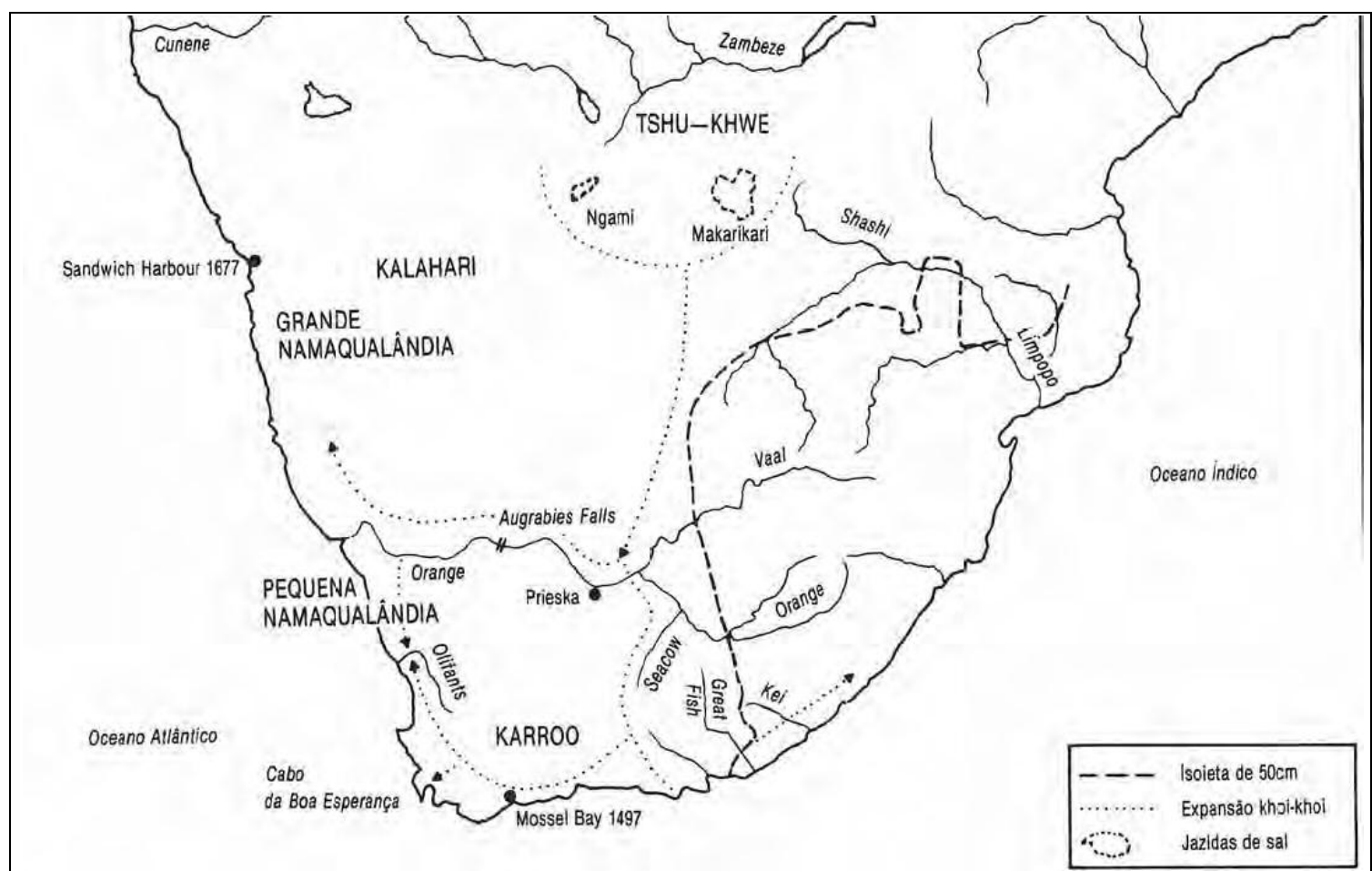

Figura 7. Mapa da expansao khoi-khoi (J. Vansina). In: In: NIANE, D. T. (Ed.). A África do século XII ao XIV. São Paulo: Brasília, 2010, p. 671.

Seguindo a linha aberta por outros investigadores nos Volumes I e II, os autores que tratam da história da África entre os séculos VII e XIV desde uma visão difusionista - consciente ou não -, defendem, portanto, que a lógica histórica do continente deveria ser entendida, basicamente, como fruto dos movimentos populacionais e das redes comerciais, que teriam existido no período em estudo. A única diferença é que adicionaram o Islamismo a esta lista, como consequência deste ter introduzido na África Sudanesa uma cultura universalista e escrita. Estes três fatores teriam sido, pois, elementos fundamentais para a formação e consolidação das sociedades africanas. $\mathrm{Na}$ medida em que tais autores buscaram enfatizar os aspectos internos desta história africana, este difusionismo faz parte da perspectiva africana, aqui delineada. A seguir ver-se-á quais as continuidades e descontinuidades que esta explicação sofrerá quando se avança para épocas mais recentes, em que o peso dos fatores e dos personagens externos se torna cada vez mais preponderante na história da África. 


\subsection{A África entre os séculos XVI e fins do século XIX (1880)}

Esta intervenção cada vez maior dos fatores externos na história da África faz com que alguns autores da $H G A$, nos volumes seguintes da obra, vejam esta história enquanto parte derivada de um processo integrativo amplo: a expansão econômica europeia-ocidental. Este é o caso de autores como I. Wallerstein (A África e a economia-mundo, Volume VI) e M. Chérif (Novos desenvolvimentos no Magreb: Argélia, Tunísia, Líbia, Volume VI). Este último autor, por exemplo, diz que não faz sentido buscar avaliações das resistências locais deste período, porque esta história é dominada à época por um fator externo: a expansão capitalista ocidental (Chérif, 2010b, p. 547). Este é um exemplo do que se intitula, neste estudo, de posições externalistas no estudo da história da África.

Todavia, sem negar a importância do comércio mundial (por ora, independente de sua caracterização), outros autores da $H G A$ vão tentar integrar este fator originalmente externo a uma visão internalista da história da África, no período citado (XVI-XIX). Entre os difusionistas intra-africanos abordados neste capítulo observa-se uma tendência a fazê-lo, destacando as consequências indiretas deste fato na história da África. Isto porque, para estes, o comércio mundial seria importante para a história da África não porque determinaria a história do continente, mas porque impulsionaria as transformações internas ali presentes. Estas sim, supostamente fundamentais para entender a história da África.

Um das questões mais analisadas nos Volumes V e VI da $H G A$, desde tal perspectiva, é a estruturação da dependência econômica e a formação de uma nova elite ou classe dominante africana, intermediária deste comércio mundial.

Como destaca M. Malowits (A luta pelo comércio internacional e suas implicações para a África, Volume IV), os dois temas estariam, historicamente, interrelacionados. Isto ocorre porque a lógica que havia estruturado a dependência econômica da África em relação à Europa, dependeria de acordos e alianças que legitimassem a troca desigual entre as partes. Enquanto as elites africanas comerciavam produtos de valor, como ouro (primeira metade do século XVI) e mão-de-obra (africanos escravizados entre XVI-XVIII), os europeus exportavam produtos de baixo custo. Com a instauração do tráfico escravista atlântico, tal situação tornou-se um fator 
evidente de subdesenvolvimento africano, por suas maléficas consequências demográficas e anti-produtivas (Malowits, 2010, p. 26; ver também: Inikori, 2010, p. 134; Ajayi, 2010a, pp. 6-10).

Em artigos específicos, autores como E. M’Bokolo (Da savana dos Camarões ao Alto Nilo, Volume V), H. Bhila (A região ao Sul do Zambeze, Volume V), A. Issacman (A bacia do Zambeze, Volume VI), A. Salim (O litoral e o interior da África Oriental de 1800 a 1845, Volume VI) e I. Kimambo (O litoral e o interior da África Oriental de 1845 a 1880, Volume VI) oferecem análises mais contextualizadas deste fato. Nestas, mostram como o tráfico de escravos e do marfim integrou-se a redes comerciais regionais anteriores da África Austral (fluviais e terrestres), potencializando o enriquecimento de uma nova classe de negociantes africanos ou mestiços (de ascendência africana e europeia), ávidos pelo poder político. Disto teria advindo novas disputas que teriam solapado o poder de antigos Estados, assim como formado outros, mais perto da costa. Sobretudo, entre os séculos XVIII e XIX.

Analises como estas apontam, portanto, para duas consequências da dependência relacionada ao comércio mundial nestes séculos. Em particular, com o tráfico escravista. A primeira seria a centralização e a militarização crescente das sociedades africanas, durante os séculos XVI-XIX. Afinal, quanto mais forte o poder político local, maior a sua capacidade de obter produtos de exportação (sobretudo escravos) e meios militares, para negociar com os europeus. A segunda seria a tendência de os novos Estados africanos se formarem ou se voltarem mais para a costa do continente que os anteriores, refletindo o redirecionamento da economia africana para os oceanos (Diagne, 2010b, p. $50)$.

Ao enfatizarem o papel intermediário de grande parcela das elites africanas neste comercio mundial, os autores da $H G A$, em sua maioria, não se limitam a ver os africanos como meras vitimas desta expansão. Algo que deriva de uma visão externalista ao próprio continente. Pelo contrário, ainda que aceitem o postulado de que este comércio fosse controlado, em ultima instância, pelos interesses europeus, observam que estas elites locais se condicionaram a este fator externo para assegurar seus ganhos econômicos e sua dominação interna.

Outra consequência indireta que alguns autores retiram da consolidação do tráfico de escravos são as jihad's na África Ocidental, no século XVIII. Tratando da Senegâmbia, em particular, B. Barry (A Senegâmbia do século XVI ao XVIII: a evolução dos Wolofes, dos Sererese dos Tucolores, Volume V), por exemplo, mostra 
como as jihad's dos marabutos ${ }^{32}$ fulbe na região seriam um reflexo do ambiente de violência generalizada ali existente. Segundo o autor, algo que se poderia atribuir à disseminação das armas de fogo e às disputas europeias, pelo controle do tráfico (Barry, 2010, p. 320). O mesmo aponta Y. Person, no artigo "Estados e povos da Senegâmbia e da Alta Guiné" (Volume VI, p. 742).

Analisando o Sudão Ocidental, de forma ampla, A. Batran (As revoluções islâmicas do século XIX na África do Oeste, Volume VI) também vê na crescente desorganização social criada pela disseminação das armas de fogo e do tráfico de escravos, entre fins do século XVIII e início do XIX, uma razão fundamental das jihad's na região. Para este autor, os letrados muçulmanos que lideravam tais revoltas apenas guiavam o descontentamento contra o caos que havia se instalado na África Ocidental (Batran, 2010, p. 634).

A importância do tráfico escravista como elemento central da história africana, desde o ponto de vista difusionista, sustenta-se em fatos teóricos e empíricos. De um modo geral, prevalece a opinião de que a amplitude e o caráter desagregador do tráfico escravista - atlântico - deveria ser visto como uma característica particular deste comércio. Algo que justificaria porque este comércio específico interferiria muito mais nas sociedades africanas, do que outras formas de comércio de exportação. Esta tese é defendida, entre outros, por autores como J. Ki-Zerbo \& K. Arhin (Estados e povos do Arco do Níger e do Volta, Volume VI, p. 812) e J. Alagoa (Do Delta do Níger aos Camarões: os fon e os ioruba, Volume V, p. 522) ${ }^{33}$.

\footnotetext{
${ }^{32}$ Dramani-Issifou (2010, p. 125) define o marabuto como o portador do direito muçulmano. Mas admite que tal termo possuiria significados distintos, no Magreb e na África Sul-saariana. Na primeira região significaria, basicamente, a referência a um santo personagem fundador de um confraria. Na África subsaariana, por sua vez, ele designaria qualquer personagem mais ou menos versado no conhecimento do Corão e de outros textos sagrados, que se utilizaria destes conhecimentos para atuar como intercessor entre o crédulo e Deus, extraindo da fonte divinatória tradicional e da prática dos talismas. Aos olhos do público, ele seria, ao mesmo tempo, sábio no sentido religioso do termo, mágico e curandeiro (DramaniIssifou, 2010, p. 117).
}

${ }^{33}$ Daí entende-se a crítica severa de B. Barry, por exemplo, aos autores que buscariam construir uma história da África Ocidental moderna, sem dar a devida importância ao tráfico escravista:

Philip D. Curtin, com o pretexto de 'descolonizar a história africana', tende a negar qualquer interferência entre a presença europeia e a evolução das sociedades senegâmbianas, por ele estudadas isoladamente (...) Eis o maior defeito do livro, por outro lado muito bem documentado, de Philip D. Curtin sobre a Senegâmbia. Nunca tentei negar a dinâmica interna própria das sociedades africanas, mas quis afirmar que sua evolução foi, desde o século $\mathrm{XV}$, cada vez mais determinada pela presença europeia. Tal presença incorporou a África ao sistema capitalista então em formação, inaugurando seu processo de dependência. Dependência esta que prossegue ainda hoje, e, como no passado, graças a aliança do capital estrangeiro com as classes dirigentes africanas. Mesmo que sob o pretexto de "descolonizar a história da África", 
Além do tráfico escravista atlântico, outra questão que é discutida pelos autores da visão difusionista da África é o chamado "comércio legítimo" (de fato, o comércio de exportações agrícolas), que foi gradativamente consolidado no século XIX. Para a maioria destes não resta dúvida de que o comércio legítimo foi algo imposto à África pelos países europeus. Especialmente a Inglaterra. Afinal, ao proibir o tráfico escravista, este país ter-se-ia consolidado como o centro da ordem economia atlântica do século XIX (Inikori, 2010, p. 95).

Muitos autores da $H G A$, no Volume VI, observam que a instauração desse comércio legítimo, em particular a partir da segunda metade do século XIX, ampliou a situação de dependência econômica das sociedades africanas. Isto porque, embora este comércio fosse menos destruidor do que o tráfico escravista, sua amplitude e interiorização aprofundavam as relações de troca desigual que permeavam as relações comerciais entre a África e a Europa. Disto se conclui que a África, no século XIX, estaria ainda mais integrada à economia mundial, direcionada pelos interesses externos. Desde tal ponto de vista, a propagação da atividade missionária e as explorações científicas (geográficas, geológicas, biólogas) no continente deveriam ser vistas com parte deste processo histórico; assim como as intervenções diretas de países europeus, como Inglaterra, Espanha e França, na política africana. Estas, se iniciando no Magreb, posteriormente se difundem na África Ocidental (com vê-se da anexação de Lagos à Coroa Britânica: 1861), no Egito e em Madagascar. Evidentemente, um fato que produziria consequências para a história destas regiões no século XIX.

A síntese destes acontecimentos poderia reforçar, mais uma vez, a explicação externalista, para quem a África seria uma vítima dos fatores extra-continentais. Mas ao destacar as consequências locais deste fenômeno pode-se concluir que tais fenômenos pertencem, também, a uma variante do argumento difusionista mais marcante deste período histórico: a estruturação da dependência econômica. No entanto, outros autores da $H G A$, não se rendem a nenhum destes pontos de vista, criando uma nova argumentação sobre o internalismo africano, no século XIX. Estes constroem o

não se pode negar essa evidência, a não ser com o objetivo de perpetuar a dependência da África. Ler, a esse respeito, a resenha de P. D. Curtin em B. Barry, 1972 (P. D. Curtin, 1973b) (Barry, 2010, p. 329).

I. Kimambo expressa o mesmo ponto de vista sobre o livro de P. Curtin (Mudanças econômicas na África Pré-colonial, 1975), em O litoral e o interior da África Oriental de 1845 a 1880 (Volume VI, p. 279). 
segundo ponto de vista difusionista sobre a história da África neste período: o renascimento africano do século XIX.

Entre estes obstinados internalistas o argumento principal é que, apesar de ampliar a dependência, o comércio legítimo teria tido consequências positivas para a evolução africana, principalmente na segunda metade do século XIX. Em primeiro lugar porque embora o fim do tráfico de escravos tenha impulsionado o trabalho servil e o tráfico interno, a África teria passado por uma mudança significativa: o fim gradativo da deportação maciça dos próprios africanos. E com o tempo estes passaram a trabalhar na produção agrícola local (Ajayi, 2010a, p. 6). Secundariamente porque sendo o comércio legítimo baseado em produtos naturais - amendoim, algodão, borracha, mel, noz-decola, óleo de palma etc - ter-se-ia possibilitado a expansão rural e uma progressiva redistribuição da renda para o povo. Em particular para os camponeses. Algo que na época do tráfico não existiria, pois a sua renda seria totalmente apropriada pelos soberanos e camadas superiores das sociedades. Deste fato poder-se-ia observar a formação de uma nova classe de ricos advindos da emergência de um capitalismo rural, africano (Boahen, 2010b, p. 73). Em suma, o século marcaria a época de um renascimento africano, que seria destruído posteriormente pelo colonialismo.

Outro tema clássico e o terceiro argumento difusionista deste item são os movimentos populacionais. Ele é inclusive objeto de estudo teórico-metodológico de J. Vansina, em Os movimentos populacionais e a emergência de novas formas sociopolíticas na África (Volume V). Este artigo de Vansina se constitui em uma das defesas mais arraigadas do ponto de vista difusionista intra-africano da $H G A$. E o fato deste ser um artigo teórico-metológico em uma obra cronológica, em que se faz uma história cronológica, mostra a centralidade dada ao assunto pelos organizadores da obra.

Neste artigo, Vansina defende que o tema dos movimentos populacionais seria um dos principais pontos em que a história da África pré-colonial diferiria da história da Europa e da maior parte da história da Ásia. Especialmente pela suposta mobilidade dos agricultores africanos, em comparação aos seus congêneres europeus e asiáticos. Isto ocorreria, segundo o autor, porque na maior parte da África Tropical e Subtropical os agricultores teriam que realizar uma cultura extensiva, visto que as terras não poderiam ser utilizadas consecutivamente por anos seguidos (Vansina, 2010c, p. 55).

Além deste fenômeno específico, entre 1500 e 1800, Vansina cita as seguintes migrações populacionais que teriam ocorrido e seriam importantes para compreender a história da África: as dos Trekboer do Cabo, a dos Somalis e dos Oromo do Chifre da 
África (correspondente ao nordeste africano), dos Ngbandi de Oubangui, dos Jagas (Djagas) da África Central, dos Tuaregues do Arco do Níger, dos Mane de Serra Leoa, dos Fulbes de toda África Ocidental e de todos os povos de Madagascar. Em suas palavras: "Tudo parece ter se passado como se, entre 1500 e 1800, nenhum povo tivesse permanecido no mesmo lugar" (Vansina, 2010c, p. 56). No século XIX, vale lembrar ainda das migrações dos Nguni, que teriam dado origem ao fenômeno histórico conhecido como Mfecane, na África Austral.

É impossível analisar aqui a história de cada uma destas migrações, além de outras movimentações populacionais conhecidas, neste vasto período histórico. É importante assinalar, entretanto, que para os autores dos Volumes V e VI da $H G A$, tal temática é abordada de um ponto de vista diferenciado do que fora realizado nos volumes anteriores da obra. Isto ocorre porque neste período histórico mais recente tais movimentos populacionais não são analisados por terem, supostamente, dado origem a sociedades complexas, como no caso clássico da expansão bantu. Mas porque, historicamente, conduziram a transformações profundas nas sociedades africanas já estabelecidas.

Este é o caso, por exemplo, das invasões dos Oromo (ou Galla) na Etiópia, que teriam reconfigurado por completo a ocupação populacional e a ordem social da região (Haberland, 2010, p. 832). O mesmo pode-se dizer do Mfecane, estudado em detalhe por L. Ngcongo (O Mfecane e a emergência de novos Estados Africanos, Volume V). Este teria surgido das migrações Nguni, do inicio do século XIX. E, em seu caminho, teriam destruído alguns Estados e formado outros, instaurando uma nova época na história da África Meridional. O mesmo tem que se dizer da expansão dos bôers e dos colonos ingleses na África do Sul. Sobretudo no século XIX, quando estes, motivados pela descoberta das jazidas de ouro e diamantes, iniciaram a conquista do interior da África Meridional, que antes vivia relativamente livre da dominação colonial (Bhebhe, 2010, p. 169).

Construída sobre fontes variáveis, portanto, a história difusionista entre os séculos XVI e 1880 se mantém sólida e coerente como perspectiva histórica, se baseando na expansão do tráfico escravista e do comércio legítimo. Por outro lado, as transformações sociais derivadas de movimentos populacionais drásticos, como o Mfecane do século XIX, parecem como mais compreensíveis e rastreáveis na memória local, do que aquelas do passado longínquo. No próximo item, se analisará a 
centralidade do colonialismo na explicação difusionista da história, entre 1880 e o século XX.

\subsection{A África entre 1880 e fins do século XX}

Esta análise da $H G A$ levanta cinco pontos primordiais da explicação difusionista da história da África neste item, que trata de fins do século XIX e século XX. Far-se-á, aqui, uma síntese destes. Mais uma vez subentende-se que tal difusionismo faz parte da perspectiva africana, na medida em que, sempre que possível, tal interpretação busca enfatizar os fatores internos, em oposição aos externos, enquanto elementos centrais da explicação histórica do continente.

Vale dizer também que esse posicionamento encontra dificuldades cada vez maiores para se impor como prerrogativa dominante da $H G A$, na medida em que se chega à época contemporânea. Isto ocorre, por um lado, porque quando mais próximo da atualidade, maior a preponderância que os fatores externos, como o colonialismo europeu, vão adquirindo na dinâmica histórica africana. $\mathrm{O}$ que tende a justificar uma interpretação da história que enfatiza o caráter condicionante destes fatores em relação aos fatores internos. Por outro lado, como destaca Ali Mazrui, editor do Volume VIII da $H G A$, quanto mais o mundo se torna uno, se "globaliza", mais difícil (e por vezes irrelevante) vai se tornando a discussão sobre fatores externos e internos para a história da África. Afinal, tudo está cada vez mais inter-relacionado (Mazrui, 2010a, pp. 9-10). Daí que muitos artigos do oitavo volume da $H G A$, que destacam este caráter relacional na sua explicação histórica, dificilmente podem ser analisados dentro do escopo de análise aqui traçado ${ }^{34}$. Algo ainda mais verdadeiro, quando os autores atribuem múltiplas determinações à explicação histórica, sem se comprometer com nenhuma delas, enquanto causa essencial dos fenômenos que se pretende explicar.

Nos dois últimos volumes da $H G A$, o caráter difusionista da história da África, entre 1880 e o século XX, derivaria, fundamentalmente, do colonialismo e da herança

\footnotetext{
${ }^{34}$ Alguns destes artigos, entretanto, dizendo-se defensores de uma história de mútuas influências, de fato, escrevem histórias externalistas da história da África. Isto ocorre porque as influências e condicionamentos externos (Europa-África) citadas se sobrepõem, largamente, às de viés oposto (ÁfricaEuropa). Este é o caso, por exemplo, do artigo de T. Chenntouf ( $O$ Chifre da África e a África Setentrional, Volume VIII).
} 
colonial na África pós-colonial. Buscar-se-á analisar as argumentações neste sentido, conforme sua ordem cronológica.

A primeira explicação difusionista sobre como o colonialismo condicionou a história da África, nestes últimos volumes da $H G A$, diz respeito às resistências africanas. A argumentação principal é de que a resistência ao colonialismo teria sido fruto, essencialmente, da emergência de novas camadas sociais, advindas do próprio sistema colonial. A primeira destas seria a dos camponeses proletarizados, que trabalhavam para as empresas agrícolas estrangeiras. A segunda seria a dos operários africanos, que trabalhavam na mineração e na construção da infra-estrutura ferroviária e de comunicações. A terceira camada social teria sido a dos intelectuais africanos, homens formados na cultura ocidental, especialmente em seu viés cristão e humanístico, para ajudar na administração colonial: padres, pastores, jornalistas, professores etc. Sem negar a importância histórica das lutas pela soberania africana contra a imposição colonial, de fins do século XIX, os autores que defendem este ponto de vista acreditam que o caráter anti-sistêmico das lutas africanas, nas primeiras décadas do século XX, derivaria da resistência econômica imposta por estas camadas sociais contra a dominação colonial (Ranger, 2010, p. 72; Vansina \& Isaacman, 2010, p. 212; Escoavelomadroso, M. 2010, p. 279; Afigbo, 2010, p. 579; Boahen, 2010d, p. 727; Davidson; Isaacman \& Pélissier, 2010, p. 832).

Outra argumentação de tipo difusionista sobre a correlação entre fatores externos e resistência africana diz respeito ao destaque dado, por alguns autores, ao islamismo, enquanto ideologia de defesa africana contra o colonialismo. Esta é a hipótese trazida, por exemplo, por H. Ibrahim (Iniciativas e resistências africanas no nordeste da África, Volume VII, em colaboração com A. I. Ali). Segundo ele, a resistência norte-africana teria sido mais ativa do que em outras regiões africanas porque lá o Islã estava mais arraigado. E, este fato, teria motivado a luta patriótica (Ibrahim\& Ali, 2010, p. 97).

A importância dos fatores externos para o surgimento dos nacionalismos africanos também é levantada por diversos autores. A argumentação neste sentido destaca a importância que as duas Grandes Guerras Mundiais (sobretudo a participação africana nestas), a Guerra Fria, os graus diversos de repressão colonial e o Panafricanismo, teriam tido como fatores impulsionadores dos nacionalismos e das lutas de independência no continente (Mazrui, 2010b, p. 133; Ki-Zerbo et al., 2010, p. 600). Em especial, na medida em que tais fatores impulsionavam a participação da 
intelectualidade africana nascente na organização e desenvolvimento das lutas de independência.

Sobre este ponto particular, alguns autores extrapolam esta periodização. A. Mazrui (O horizonte 2000, Volume VIII), por exemplo, defende que as competências (cultura humanística) e as incompetências (formação tecnológica) das elites africanas pós-coloniais, seriam uma consequência da manutenção desta tradição colonial na educação. Em sua opinião, a formação humanística e cristã daí derivada teria acelerado as emancipações políticas, mas comprometido a autonomia e o desenvolvimento econômico dos países africanos (Mazrui, 2010c, p. 1113).

O terceiro argumento difusionista fala sobre a dependência econômica da África, em relação à Europa, como o fator primordial que move a história da África, entre os séculos XIX e XX. Isto porque, como afirma W. Rodney (A economia colonial, Volume VII), o colonialismo teria imprimido, pela coerção, a inclusão cotidiana das populações africanas às dinâmicas flutuantes e desiguais da ordem econômica internacional. A consequência deste fato é que quanto mais integrada ao colonialismo e a dependência mais as populações africanas ficariam vulneráveis a fatores externos, alheios a sua existência (Rodney, 2010, p. 399).

Os efeitos desta integração econômica dependente na África, na primeira metade do século XX, é o tema dos artigos de C. Coquery-Vidrovitch (A economia colonial das antigas zonas francesas, belgas e portuguesas: 1914-35, Volume VII) e M. Kaniki (A economia colonial: as antigas zonas britânicas, Volume VII). Aí se destacam, sobretudo, as consequências econômicas e sociais que as duas Grandes Guerras ${ }^{35}$ e a depressão econômica mundial, na década de 1930, tiveram para as sociedades africanas, parasitadas pelo colonialismo. Tratando da segunda metade do século XX, M. Osuwu (A agropecuária e o desenvolvimento rural, Volume VIII), A. Adedeji (Estratégias comparadas de descolonização econômica, Volume VIII) e D. Chinweizu (A África e os países capitalistas, Volume VIII), por outro lado, sustentam que a estagnação da economia africana pós-colonial derivaria, essencialmente, da conservação de estruturas herdadas do colonialismo, como a desindustrialização e o caráter exportador e monocultor do setor agrícola. Daí poder-se-ia concluir que se trataria de posições externalistas, visto o caráter estruturante desta dependência econômica. Todavia, como deixa evidente o artigo de A. Adedeji, esta dependência, originalmente externa,

\footnotetext{
${ }^{35}$ Neste particular, ver também as análises mais pormenorizadas de M. Crowder (A Primeira Guerra Mundial e suas conseqüências, Volume VII; A África sob domínio britânico e belga, Volume VIII).
} 
continua existindo porque se reproduz internamente nas sociedades africanas (Adedeji, 2010, p. 503). Sobretudo, no gosto pela ostentação e pela riqueza fácil, que marcaria o capitalismo colonial em África (Ki-Zerbo et. al., 2010, p. 596). Fala-se, pois, em condicionamento, mas não em determinação.

Outros autores também destacam a importância do fenômeno colonial para aspectos essenciais da história da África, no século XX. Este é o caso dos estudos que destacam o efeito catalisador e problemático que a dominação colonial teria tido para a evolução demográfica e a urbanização do continente. Este é o quarto argumento difusionista citado neste item. Este assunto é retomado nos artigos de J. Caldwell (As repercussões sociais da dominação colonial: aspectos demográficos, Volume VII), A. Afigbo (As repercussões sociais da dominação colonial: novas estruturas sociais, Volume VII), C. Coquery-Vidrovitch (As mudanças econômicas na África em seu contexto mundial: 1935-1980, Volume VIII) e P. Kipre (O desenvolvimento industrial e o crescimento urbano, Volume VIII). Além dos aspetos econômicos e sociais diretamente derivados de tais fatores, autores como A. Afigbo (artigo citado) destacam outras consequências supostamente derivadas da predileção do urbano sobre o rural, criada pelo colonialismo. Seria o caso do primado do masculino sobre o feminino, a expansão do cristianismo e do islamismo, o fascínio pelo moderno e a crescente mobilidade social (Afigbo, 2010, pp. 577-580).

Além das resistências e dos nacionalismos africanos, da dependência econômica, da urbanização e da evolução demográfica, os autores da $H G A$ destacam o campo da política de Estado, como outra temática relevante para a compreenção da continuidade do colonialismo na história da África, do século XX.

Este tema novo é tratado no artigo de J. Elaigwu (Construção da nação $e$ evolução das estruturas políticas, Volume VIII; em colaboração com A. Mazrui). Para estes autores, a necessidade de construir uma nação, onde antes existia apenas um território colonial, fez com que muitas elites políticas africanas, pós-coloniais, reproduzissem o autoritarismo centralizador do Estado colonial. Por isto que na África pós-colonial a política, nascida do ideal de nação, teria se tornado algo instável e restrita às disputas pelo poder de Estado. A opção pela via militar e o desrespeito contumaz aos direitos humanos, para os autores, seriam, pois, consequências desta política centralizadora, geneticamente derivada do colonialismo (Elaigwu \& Mazrui, 2010, pp. 560-563). 
Destacou-se, neste item, diversos fatores que concretizam uma explicação difusionista para a história da África, no século XX. Vale dizer que, à exceção da presença do Islamismo no nordeste da África, levantado por I. Ibrahim (Iniciativas $e$ resistências africanas no nordeste da África, Volume VII, em colaboração de A. Ali), todos os demais fatores externos aí destacados derivariam, direta ou indiretamente, da existência do colonialismo no continente africano. Sendo assim, pode-se concluir que este tema é o elemento dominante da história da África no século XX, para a visão difusionista da África construída pela perspectiva africana da $H G A$.

\subsection{Considerações parciais}

A visão difusionista intra-africana é a explicação mais presente nos artigos da $H G A$. Por isto, são muitos os exemplos e citações possíveis que poderiam ser tratados neste capítulo. A síntese aqui apresentada revela as linhas gerais de como esta explicação histórica é aí utilizada, para nortear a história da África.

Esta análise evidencia que para o período antigo da África, entre o Neolítico e o século VI (d. C), esta visão histórica se baseia em dois temas fundamentais: os movimentos populacionais e o comércio internacional, na Antiguidade. Como visto, estas duas temáticas continuam essenciais para a história da África, até fins do século XIX. A única diferença primordial são as transformações neste comércio mundial, que passaria da centralidade mediterrânica da Antiguidade, para a muçulmana e, posteriormente, para a atlântica, com o tráfico escravista. Um fato que possuiria implicações importantes para as regiões africanas afetadas, direta e indiretamente, por este comércio. Dentro desta visão difusionista, o único elemento que é adicionado a esta história africana seria o islamismo, a partir do século VII. Isto porque, para alguns autores da $H G A$, além da islamizaçãos dos berberes, dever-se-ia notar a importância do "islamismo de corte", que teria sido um fator decisivo para a consolidação e desenvolvimento, por exemplo, dos Impérios Sudaneses, na época medieval.

Este último ponto merece atenção. Afinal, vale lembrar que tais elementos tornam-se importantes para esta macro-narativa da história da África, sobretudo até o século XVI, justamente porque são tidos como elementos essenciais que explicariam a consolidação e o desenvolvimento das sociedades complexas no continente africano. 
Em suma, para os difusionistas, tais elementos podem não ter sido os únicos ou os primeiros neste processo, mas foram fundamentais nele.

Tal visão da história se mantém nestes parâmetros até fins do século XIX, com o advento do colonialismo. Com a entrada deste novo ator em cena, é interessante notar que os elementos antes tidos como essenciais para a história da África - comércio mundial, islamismo, movimentos populacionais - tornam-se praticamente irrelevantes na história difusionista da $H G A$. Sendo substituídos por outros, direta ou indiretamente derivados do sistema colonial, como a formação de novas camadas sociais, a ascensão do urbano frente ao mundo rural, o aprofundamento da dependência econômica, a reprodução da educação colonial, o desafio demográfico etc.

A constatação destes fatos leva a perceber que, nesta visão da história, há dois fatos históricos originalmente externos que deveriam ser vistos como rupturas novas e decisivas na história da África. O primeiro seria o islamismo. O segundo, mais marcante, o colonialismo.

Esta abordagem histórica poderá ser melhor avaliada comparativamente, quando se tiver clareza das escritas alternativas da história da África, dentro da perspectiva africana, construída pelos demais autores da $H G A$. Algo que, neste trabalho, será analisado em termos de explicação pelo sujeito africano e pelo regionalismo. 


\section{Capítulo 3: O sujeito africano na história da África da $H G A$}

\section{1 . Periodização}

Este capítulo sintetiza a abordagem do sujeito africano construída pela perspectiva africana da $H G A$. Esta abordagem se constrói como uma explicação histórica que visa destacar a ação deste sujeito africano, da forma mais ampla possível. Sua presença faz-se marcante sobretudo nos momentos históricos em que os fatores externos são estruturalmente dominantes, como no colonialismo imperialista. Aí, o sujeito africano é visto como um pólo de resistência a tais fatores.

Todavia, não é apenas na história recente da África que a abordagem do sujeito africano se embasa. Isto porque, como se verá a seguir, alguns artigos da $H G A$ utilizam-na como um enfoque de longa duração da história da África. Por isso, vê-se a defesa desse sujeito como uma alternativa teórico-metodológica que merece o mesmo destaque das demais explicações internalistas nas histórias da África da $H G A$ : o difusionismo intra-africano e o regionalismo.

Vale lembrar que o que se expõe neste capítulo, assim como nos anteriores, é uma síntese da escrita da história na $H G A$. Portanto, as referências e comentários se circunscreveram aos artigos presentes nesta obra específica. Devem ser lidos, portanto, como parte de uma investigação empírica e holística. Evidentemente, pode-se avaliar em que medida tal reflexão serviria como um comentário geral acerca da historiografia sobre África. Todavia, esse não é o tema deste trabalho.

Dito isso, propõe-se aqui, mais uma vez, uma periodização de acordo com os princípios próprios da abordagem analisada. Para isso, se caracteriza tal periodização de acordo com quatro experiências históricas do sujeito africano apontadas na obra, com suas respectivas datas aproximativas: a) A experiência egípcio-faraônica (3.200 a. C. 332 a. $C^{36}$ ); b) A civilização berbere-magrebiana (146 a. $C^{37}$. - século XIV d. C.); c) As

\footnotetext{
${ }^{36} 3.200$ marca o inínio do período arcaico do Egito Faraônico. 332 a. C. marca a invasão do exército de Alexandre, o "Grande", que pos fim a soberania egpícia, que já se via ameaçada desde o fim do Império Novo (1.085 a. C.).

${ }^{37}$ Destruição de Cartago pelos romanos.
} 
diásporas africanas (VII - XX); d) As resistências africanas contra o colonialismo e o neo-colonialismo europeu (XIX e XX). O conjunto dessas experiências é o conteúdo da abordagem do sujeito africano, na $H G A$.

Vale dizer que, embora se leia muitas frases em contrário na referida obra, a abordagem do sujeito africano é um enfoque menor desta, diante do espaço ocupado pelo difusionismo intra-africano. De fato, ela é hegemônica apenas no sétimo Volume da obra: A África sob dominação colonial (1880-1935), editado por A. Boahen.

\section{2 . A experiência egípcio-faraônica (3.200 a. C. - 332 a. C.)}

A identificação do sujeito africano enquanto portador de uma existência ancestral, em alguns artigos da $H G A$, deriva de sua suposta proximidade física e "racial" com os africanos sul-saarianos. Esse assunto merece consideração. De um modo geral, os termos raça ou etnia, para caracterizar a população negra, são pouco utilizados na HGA. Como observa Devisse (2010a, p. 843), tratando de um assunto particular (o povoamento do antigo Egito), tal fato parece ser resultante da hesitação dos estudiosos em utilizar tais termos por serem vistos como potencialmente perigosos ou pejorativos.

Esse desacordo sobre a temática é especialmente perceptível nos estudos sobre a África Antiga, na $H G A$. Nos três primeiros volumes da obra, para definir uma fisionomia tipicamente sul-saariana de populações africanas (antes da presente Era), faz-se uso de termos como "negroide", "negro" ou "proto-negro", (Por exemplo: Lwanga-Lunyiigo \& Vansina, 2010, p. 194; Diop, 2010, p. 1; Desanges, 2010, p. 452). Todavia, esta utilização não é homogênea, nem consensual. A polêmica fica evidente no resumo das atas do Colóquio "O povoamento do antigo Egito e a decifração da escrita meroítica" (Cairo, 1974), anexadas ao Volume II. Aliás, a própria presença destas atas na $H G A$, mostra a importância dada ao tema pelos organizadores da obra.

Pelo que se pode observar de tais atas, a oposição presente no referido Colóquio se estabeleceu entre dois grupos primordiais. O primeiro deles, formado por C. A. Diop e T. Obenga, defendia que se podia definir os antigos egípcios e núbios como negros, por suas características físicas e culturais. Esta unidade seria fruto de uma origem histórica comum da região dos Grandes Lagos, e ter-se-ia mantido na época histórica. O 
segundo grupo era formado por aqueles que negavam a validade de tal conceitualização. Este grupo parece ter-se divido em dois. Alguns estudiosos defendiam que os antigos egipcios seriam, na verdade, mestiços, de origem mediterrânica e africana (Abu Bakr, Vercoutter, Ghallab, El-Nadury, Sauneron). Outro grupo negava a validade de tais definições, baseadas em critérios físicos (Leclant, Gléglé, Save-Soderbergh). A querela se baseia em análises de fontes primárias (pictóricas, literárias) e secundárias, derivadas de exames químicos, linguísticos e de antropologia físíca (Devisse, 2010a, pp. 821856).

$\mathrm{Na} H G A$, a abordagem do sujeito africano em sua existência ancestral, ou seja, em se tratando da África Antiga, antes da presente Era, depende do primeiro grupo aqui estabelecido: Diop-Obenga. Isto porque, a tipificação que estes estabeleceram dos antigos africanos, em especial, dos egípcios, como negros, permite a valorização do passado africano, enquanto parte de uma mesma história "étnico-racial"38.

$\mathrm{O}$ artigo de C. A. Diop (A origem dos antigos egípcios, Volume I) é um clássico desse tipo de abordagem. Neste texto, Diop se utiliza de dados das mais variadas fontes - primárias e secundárias - para defender a origem africana e negra dos antigos egípcios. Tais fontes, para o autor, comprovariam não apenas que os egípcios eram tratados como negros (em sua diversidade), por outros povos à época (especialmente os gregos e hebreus), como eles mesmos se atribuiriam tal identidade étnico-racial. Sua argumentação se baseia em uma quantidade e diversidade de materiais, que só podem ser avaliados por especialistas das áreas distintas do conhecimento, trabalhadas por Diop.

\footnotetext{
${ }^{38}$ Faz-se necessário esclarecer a utilização deste termo. Na HGA, tanto Obenga (Devisse, 2010a, p. 842), quanto Diop (Diop, 2010, p. 36), acreditam ser lícito a utilização do termo "raça" como categoria científica, mas nenhum deles dá uma explicação pormenorizada do assunto. Esta utilização, no entanto, conforme aí delineada, parece ser um misto de características culturais e da herança biológica. Daí a utilização do termo "étnico-racial", que não se encontra na $H G A$. Na própria obra, a única fonte que trata diretamente da questão é um artigo de Joseph Ki-Zerbo: "Teorias relativas às "raças" e a história da África" (Volume I). Neste artigo, Ki-Zerbo defende que existiria um sentido científico para a utilização do termo "raça". Esta utilização, evidentemente, não estaria alicerçada nas antigas teorias raciológicas do século XIX, como a de A. Gobineau. Ela se basearia em uma análise evolucionista de longa ou mesmo longuíssima duração dos agrupamentos humanos. Para isto, dever-se-ia estar atento para dois fenômenos primordiais para a definição das "raças": a) o isolamento sexual; b) a diversificação adaptativa (Ki-Zerbo, 2010b, pp. 283-284). No entanto, diz Ki-Zerbo, quanto mais a humanidade interage, mais difícil seria a definição de critérios objetivos para tipificar as "raças" humanas. Neste sentido, acredita o autor que tais "raças" deveriam ser vistas como um fenômeno dinâmico, dependente dos fluxos genéticos e culturais cada vez mais intensos entre os povos; objetivamente cada vez mais mestiços (Ki-Zerbo, 2010b, p. 289). Creio que esta definição de Ki-Zerbo dá uma boa pista, a partir da própria $H G A$, sobre a utilização do conceito de "raça", em Diop e Obenga.
} 
Não resta dúvida, entretanto, que o autor estava seguro de estar contribuindo para uma reconstrução da história da África, voltada para a auto-valorização do papel da África e dos africanos na história humana. Neste sentido, ele destaca o seguinte:

Este estudo torna necessário que se reescreva a história da humanidade a partir de um ponto de vista mais científico, levando em conta o componente negro-africano, que foi, por longo tempo, preponderante. Assim, é doravante, possível constituir um corpus de ciências humanas negro-africanas apoiado em bases históricas sólidas, e não suspenso no ar. Finalmente, se é fato que só a verdade é revolucionária, deve-se acrescentar que só um rapprochement realizado com base na verdade será duradouro. Não se contribui para a causa do progresso humano lançando um véu sobre os fatos.

A redescoberta do verdadeiro passado dos povos africanos não deverá ser um fator de divisão, mas contribuir para uní-los, todos e cada um, estreitando seus laços de norte a sul do continente, permitindo-lhes realizar, juntos, uma nova missão histórica para o bem da humanidade (Diop, 2010, p. 36, itálico original).

Trata-se de um artigo de exceção na $H G A$, por trazer uma defesa explícita da abordagem do sujeito africano. O próprio autor pareceria estar consciente deste fato. $\mathrm{O}$ que explica frases como a seguinte: "compreende-se como é dificil escrever um capítulo como este numa obra deste gênero, na qual o eufemismo e a transigência, via de regra, prevalecem" (Diop, 2010, p. 34) ${ }^{39}$.

É importante perceber como esta posição de Diop é diferente daquela trazida por outros especialistas da $H G A$, mesmo quando estes mencionam o fato de uma população antiga poder ser identificada como negra. Por exemplo, S. Adam, no artigo $A$ importância da Núbia (Volume II, em colaboração com J. Vercoutter) se reporta ao fato de que, indiscutivelmente, os núbios antigos (antes da presente Era) eram negros. Algo que o autor atesta por fontes diversas, trazidas por documentos de época de povos vizinhos a eles: gregos, egípcios, etíopes, romanos. No entanto, o autor não retira daí nenhum fato relevante para a sua construção histórica. Pelo contrário, se limita a dizer que, "não é nossa intenção entrar, ainda que pudéssemos, no debate puramente antropológico acerca da origem "negra" ou "camitica" dos núbios". Afinal, para ele, o

\footnotetext{
${ }^{39} \mathrm{O}$ artigo de Diop termina com a seguinte nota, que vale citar:
} 
importante é que os núbios eram africanos por sua língua e civilização, e não por seu suposto pertencimento étnico-racial (Adam, 2010, p. 219).

Em suma, para Adam (e outros), os núbios seriam, de fato, negros, mas isto não mudaria em nada a essência de sua história. Enquanto que, para Diop, o fato dos egípcios serem vistos como negros e, mais do que isto, se verem como tal, seria algo fundamental para o desvelamento de uma verdadeira história da África. A diferença entre um ponto de vista e outro é importante.

\subsection{A civilização berbere-magrebiana (146 a. C. - XIV d. C.)}

Outra temática em que transparece uma postura afirmativa do sujeito africano na HGA é a história dos berberes, nos Volumes II e III da obra. Todavia, antes de adentrar neste ponto específico, vale lembrar a origem histórica destas populações. J. Desanges mostra em seu estudo (Os protoberberes, Volume II), que os líbios - considerados protoberberes por este autor - seriam originários da mistura milenar de três grupos populacionais: ibero-maurusiense, capsiense e comunidades neolíticas, particularmente, a sudanesa (Cartum). Estes grupos teriam formado uma raça, cultura e língua própria (pertencente ao tronco camito-semita), no Magreb antigo, antes da presente Era. Esta seria a origem dos povos magrebianos que teriam se formado, provavelmente, no último milênio a. C, como os Garamantes, Númidas e Mauritânios. A partir de fins deste último milênio ter-se-ia somado a esse substrato antigo os elementos de origem fenícia, advindos de Cartago (Desanges, 2010, pp. 451-459). Os berberes, portanto, no início da presente Era, seriam um conjunto diverso de povos, biológica e culturalmente mistos, cujas principais origens seriam regionais, ancestrais (híbrida e milenar) e púnicas (cartaginesa).

Desde a abordagem do sujeito africano, na $H G A$, a história dos berberes ganha relevância a partir dos primeiros séculos da presente Era. Não por acaso, quando esta história se refere à luta dos berberes contra o domínio romano, no Norte da África. Os artigos que tratam deste assunto são os de A. Mahjoubi (O período romano, Volume II) e P. Salama (De Roma ao Islã, Volume II) - partes de uma mesma seção, intitulada: $O$ período romano e pós-romano no Norte da África. 
No primeiro artigo, Mahjoubi defende que se necessitaria rever a historiografia tradicional, de viés colonialista, sobre esse período no Magreb. Isto porque, segundo ele, ela buscaria legitimar o seu próprio colonialismo - francês - interpretando o colonialismo romano no Norte da África como um processo de pacificação, sem atentar para a resistência berbere a tal domínio (Mahjoubi, 2010, p. 501).

Contrapondo-se a tal narrativa, o autor defende que as revoltas berberes teriam sido uma constante na história do Norte da África, desde os primórdios da ocupação romana na região, após a destruição de Cartago (146 a. C.). A razão primordial para este fato, segundo o autor, seria que a conquista romana teria se baseado no controle sobre as melhores terras da região, algo inaceitável aos berberes. Tais lutas teriam sido vistas por historiadores modernos como bárbaras, na medida em que impediriam o florescimento de uma civilização agrária, em prol de uma vida berbere, nômade ou seminômade. Todavia, diz o autor, contra a exploração e usurpação romana, a resistência armada seria a única esperança à época. Nesta resistência, tratar-se-ia tanto de revoltas estatais, como as lideradas pelos Garamantes, Númida, Musulâmios, Getulos, quanto populares, advindas de guerrilhas rurais, nômades. Tal resistência, diz o autor, ainda pouco documentada, mostraria que os povos berberes nunca teriam sido, de fato, subjugados pelos romanos apesar da colonização que se estabeleceu na região a partir de 40 d. C. (Mahjoubi, 2010, p. 503).

Além dessas revoltas armadas, afirma Mahjoubi, os limites deste colonialismo romano poderiam ser atestados pelo florescimento da cultura berbere no norte-africano. Isto porque, esta, não só teria se mantido durante o período de dominação romana (até o século $\mathrm{V}$ d. C.), mas teria evoluído e se diversificado à época, com a inclusão de novos elementos de origem helenística, cristã e romana. Isto seria perceptível, por exemplo, no estudo da religião e da arte norte-africana, durante este período. Nesse sentido, ele argumenta que, embora a romanização tenha modificado muitos aspectos formais destas expressões culturais, o conteúdo profundo destas continuariam a ser africanos, de origem líbico-púnica (Mahjoubi, 2010, p. 539-544). Em suma, deste modo, o sujeito berbere ter-se-ia mantido, mesmo quando derrotado militarmente.

P. Salama dá continuidade a abordagem de Mahjoubi no texto complementar desta seção, intitulado De Roma ao Islã (Volume II). Neste artigo, Salama trata do Norte da África entre os séculos IV e VII. Neste curto período, esta região da África foi alvo de duas invasões de povos não africanos. A primeira foi a dos Vandalos. Estes 
foram conquistadores de origem germânica, que iniciaram a ocupação da costa litorânea norte-africana em 429 (d. C.); tendo-se retirado da região em 533 (d. C). A segunda foi a dos Bizantinos. Estes expulsaram os Vândalos e estabeleceram seu domínio na costa africana até fins do século VII. Nesta época, foram vencidos e expulsos da região pelos muçulmanos árabes (Salama, 2010a, pp. 545-548).

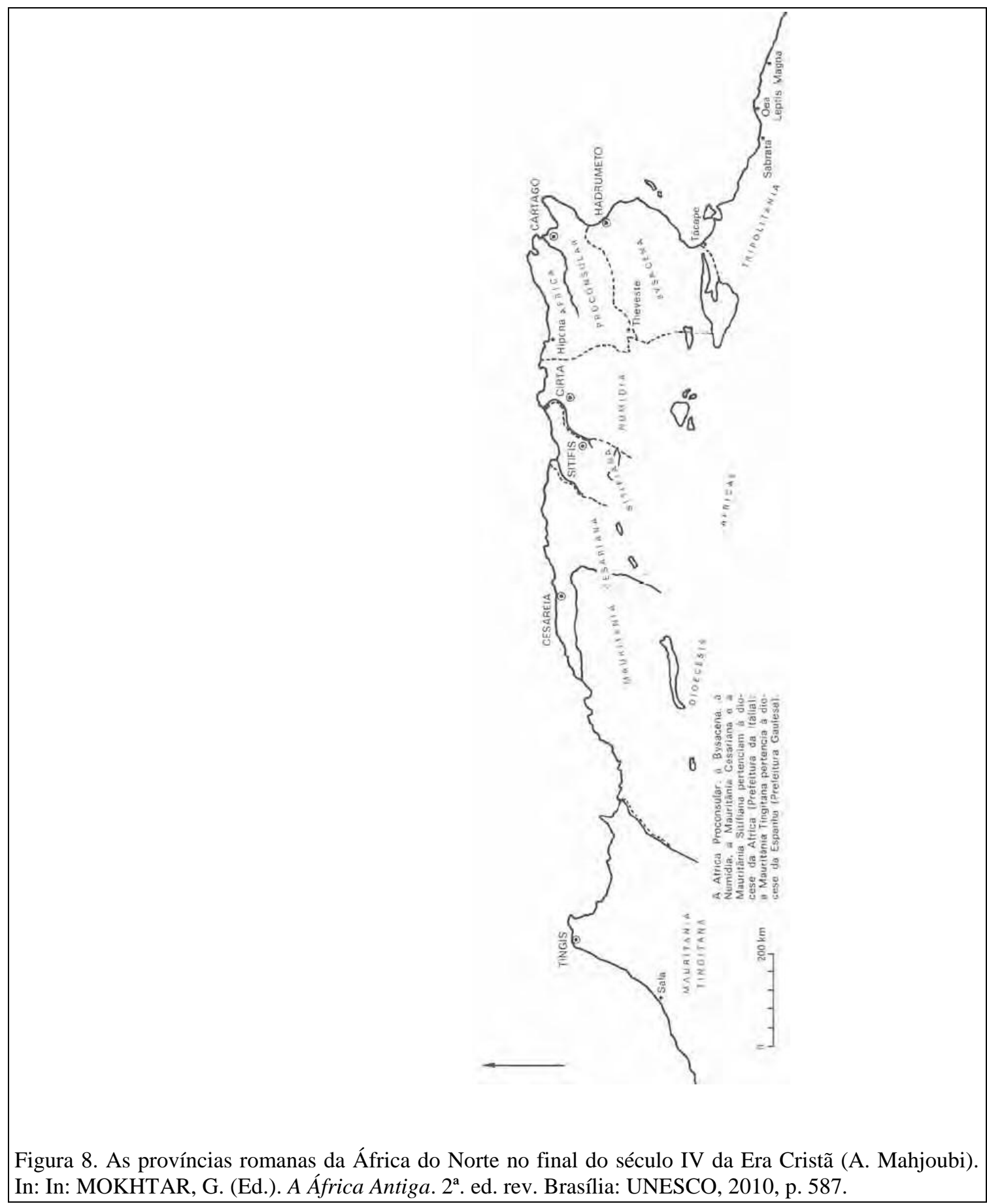


Diz Salama que, apesar desta história turbulenta, no período em estudo, poderse-ia observar uma vida independente dos berberes da África do Norte. Em particular, nas regiões montanhesas e interioranas. Esta história própria teria sido construída pela ação dos "mouros", que seria a denominação geral de época referente aos rebeldes norte-africanos (Salama, 2010a, p. 549). Isso porque, segundo o autor, foi a resistência política destes que teria possibilitado a existência de reinos autônomos locais à época, como os Masuna, Mauritânia e Hodna.

Salama atribui essa marca dos mouros a uma característica mais geral das populações berberes rurais da época. Em suas palavras, tratar-se-ia da "força irresistível de independência e ruptura que inspirava o espírito das massas rurais". O autor diz que se poderia comprovar tal fato nos sucessivos ataques sofridos pelas populações citadinas durante este período, apesar da dominação estrangeira - vândala e bizantina - ser ali especialmente forte (Salama, 2010a, p. 554). Neste sentido, conclui o mesmo, a "eterna África" teria recuperado gradativamente os seus direitos. Conseqüentemente, a presença estrangeira, próxima ou distante, teria sido ali considerada pelos berberes apenas como um fardo. Algo que o autor, em suas palavras, vê como um reflexo do "inextinguível espírito de independência e a imensa firmeza de objetivos que é a marca imutável da história da África do Norte" (Salama, 2010a, p. 560). Em suma, para Salama, o sujeito berbere, africano, seria caracterizado, sobretudo, por este espírito de independência que marcaria a história norte-africana. Uma observação bastante próxima a de Mahjoubi.

É interessante notar nas páginas da $H G A$ como a chegada do islamismo no norte da África, a partir do século VII, muda esta visão positiva dos berberes construída por autores como Salama e Mahjoubi. No segundo capítulo deste trabalho comentou-se que a maioria dos capítulos iniciais do Volume III da HGA seriam marcados por uma visão externalista - islamocêntrica - da história norte-africana, entre os séculos VII e XII. Pois bem, tal fato traz uma ruptura radical da interpretação do sujeito berbere aqui analisado. Isto ocorre porque quando se trata de estudar a ocupação muçulmana do Magreb, os autores islamocêntricos na $H G A$ transformam a resistência berbere a tal evento em algo negativo. É uma inversão do argumento anterior. Diante do colonialismo romano tal resistência seria necessária e positiva. Todavia, diante do colonialismo árabe-islâmico a mesma resistência passa a ser vista como negativa.

O melhor exemplo deste fato é o artigo de M. El Fasi (A islamização da África do Norte, Volume III). Citou-se que o autor chega a rotular tal resistência berbere como 
selvagem (Fasi, 2010a, pp. 75-77). No mesmo sentido, ele apresenta o movimento dos Barghawāta $^{40}$, do século VIII, como uma "heresia" contra o Islã, silenciando a sua originalidade e positividade, como parte da luta anti-colonialista berbere (Fasi, 2010a, p. 81). Tais comentários só fazem sentido admitindo que, para Fasi (e outros), não se tratava aí de estudar a história da resistência africana, mas a história dos vencedores islâmicos.

Para não dizer que a atitude destes autores é totalmente negativa em relação aos berberes, deve-se dizer que eles reconhecem, por exemplo, a importância do kharidjismo entre estes. No entanto, a referência a tal fato é feita com o intuito de comprovar que a luta berbere não era contra o Islã, mas contra a classe dirigente árabe (Fasi, 2010a, p. 80). Do mesmo modo, vale lembrar que, na $H G A$, existem dois artigos que trazem informações importantes e detalhadas dos povos berberes à época da invasão muçulmana (A conquista da África do Norte e a resistência berbere, Volume III; $O$ papel do Saara e dos saarianos nas relações entre o Norte e o Sul, Volume III). Nestes, se detalha, por exemplo, as complexas sub-divisões populacionais entre os berberes: sanhādja, kutāma, talkāta, awrāba, tuaregues, masmūda, zanāta, hawwāra, luwāta, nafūsa, zaghāwa etc. Entrementes, mesmo nestes artigos, não há uma interpretação positiva da luta berbere contra o Islã. Quanto mais, uma abordagem desta luta como parte de uma história mais longa e autônoma do sujeito berbere, tal qual defendida por Salama e Mahjoub.

A conclusão que se chega é que na $H G A$, em relação ao Islã, não há uma visão dos berberes enquanto sujeitos da luta anti-colonialista. Por esta razão é que, como se verá a seguir, a história norte-africana e saariana só se torna parte deste tipo de interpretação, novamente, quando ela pode ser incorporada a uma luta mais ampla do Islã contra a Europa Cristã. No entanto, antes de adentrar em tal exposição, cabe destacar um artigo da $H G A$ que trata da difusão islâmica na África, no Volume III, que não sucumbe à tentação externalista desta temática. Trata-se do estudo de Z. DramaniIssifou (O Islã como sistema social na África, desde o século VII, Volume III).

\footnotetext{
${ }^{40}$ Os Barghawāta seriam uma fração dos masmūda, população berbere que povoava a planície do litoral atlântico do Marrocos. O movimento foi criado pelo chefe Sālih ibn Tarīf, que se proclamou profeta em 744 d. C. Ele redigiu um Corão em língua berbere, bem como um código de leis rituais e religiosas inspirado essencialmente nos costumes locais. Sālih fez-se chefe de um Estado independente e os seus sucessores continuaram a exercer domínio sobre grande parte do litoral atlântico marroquino, até o século XI. Nesta época, foram derrotados pelos almorávidas (Fasi, 2010a, p. 80).
} 
A originalidade deste estudo é que ele trata a islamização na África não como um processo irreversível - guiado por forças externas ou internas (difusionismo intraafricano) -, mas como uma escolha dos próprios africanos; condicionada por seus contextos particulares e pelo tipo de islamismo dominante em cada região africana, no tempo e no espaço: malikismo, sunismo, chafismo, sufismos, kharidjismo etc ${ }^{41}$ (Dramani-Issifou, 2010, pp. 115-118). Isso seria assim, diz o autor, por dois fatores primordiais. O primeiro é que, na realidade histórica tais tendências teriam trazido propostas diferentes de como se relacionar com os modos de vida divergentes do Islã original, árabe. Por outro lado, porque não se poderia entender tais escolhas sem estudos sobre o contexto africano, local. Afinal, para o autor, em termos gerais, tais escolhas teriam sido mais motivadas por fatores específicos de ordem política e econômica, do que pelos de ordem religiosa e teológica (Dramani-Issifou, 2010, p. 120).

O exemplo mais recorrente do autor para comprovar sua tese são as conversões ao Islã dos soberanos sudaneses, entre os séculos IX e XIV. Diz ele que, até o século XIV, a tendência dos soberanos sudaneses em converter-se ao islamismo teria criado um modo próprio de ser islâmico que não implicava a arabização. Deste modo, em tese, eles podiam tentar ficar com o "melhor" dos dois mundos, islâmico e africano, sem se limitar a nenhum deles. Por exemplo, com a islamização, ter-se-ia facilitado a criação de laços de confiança destes para com os mercadores e eruditos muçulmanos. Algo que dependia, entre outras coisas, concomitantemente, do grau de tolerância que tais grupos islâmicos - em suas variadas tendências - davam a estes novos convertidos. Por outro lado, ao mesmo tempo, como se tratava, em geral, de uma islamização superficial, tais soberanos continuavam tendo a possibilidade de se legitimar diante de sua população a partir de esferas locais de poder e dominação. No entanto, diz o autor, na medida em que diversas variáveis eram aí manipuladas tais soberanos nunca estavam em uma situação cômoda. Eles estariam integrados a uma rede de relações e interesses complexos, marcados por essa dicotomia civilizacional entre o modelo africano sudanês - e o islâmico. Ambos, com suas variantes internas (Dramani-Issifou, 2010, pp. 126-134).

Independente de se concordar ou não com a interpretação do autor é justo ver aí uma importante contribuição à analise do sujeito africano na $H G A$. Sobretudo, porque

\footnotetext{
${ }^{41}$ A explicação mais concisa destas tendências, na $H G A$, se encontra nos artigos de M. El Fasi \& I. Hrbek para oVolume III da obra: "O advento do Islã e a ascensão do Império Muçulmano" e "Etapas do desenvolvimento do Islã e da sua difusão na África".
} 
ela cria uma alternativa teórico-metodológica para uma visão anacrônica e externalista da expansão islâmica (dominante no Volume III da obra), como um processo linear, concretizado pela conversão inevitável das populações africanas. Um tipo de interpretação que o próprio Dramani-Issifou associa à hegemonia islâmica e arabizante, marcante na historiografia sobre a expansão do Islã. É isto o que o autor comenta na seguinte passagem:

Efetivamente, a penetração do islã em direção ao mundo negro reveste-se de aspectos muito complexos (...) Esta situação está na base de um debate, surdo e sutil, no qual os pressupostos ideológicos de diferente natureza não estão ausentes. Ele opõe duas tendências, na explicação ou, antes, na interpretação histórica da conversão da África mediterrâneaao islã. De modo geral, os historiadores orientais e do Oriente Médio, árabes ou não, os das regiões africanas culturalmente influenciadas pelo Oriente Médio (Egito, Sudão, Líbia e Tunísia), os do restante do Magreb, e, além disso, islamizantes, aceitam mal ou rejeitam sem nuances a tese da conquista árabe como preliminar a conversão das populações. Corroborando com o seu ponto de vista, eles avançam o argumento segundo o qual o islã não admite as conversões forçadas. Os outros historiadores africanistas, quase todos especialistas como os primeiros nas questões muçulmanas e relativas a expansão do islã, estão divididos entre aqueles que apóiam as suas análises sobre o fenômeno da conquista e aqueles que delas aceitam o fato, conduzindo-o as suas justas proporções históricas, sob uma ótica lançada sobre longo período. Estes últimos são encontrados junto aos ocidentais, os africanos subsaarianos e, em menor escala, junto aos magrebianos (sobretudo Marrocos) berberizantes. Simples querelas entre escolas? Não acreditamos e sugerimos que este debate seja importante para a compreensão do conjunto dos fatos humanos sociais e culturais - relacionando árabes e povos da África. Em suma, pensamos que o encontro entre estes povos tenha, primeiramente, sido uma questão mais política e econômica que religiosa (DramaniIssifou, 2010, pp. 119-120).

Em resumo, colocando-se contra visão islamocêntrica dominante no mundo árabe e no Norte da África (a exceção dos "magrebianos berberizantes"), o autor julga estar contribuindo com uma interpretação mais completa da expansão árabe. Para isso, analisa-a como um fenômeno de conquista, que deveria ser estudado em suas "justas proporções históricas, sob uma ótica lançada sobre longo período". Na medida em que a sua contribuição na $H G A$, aborda o tema da "escolha africana" em relação a esta expansão islâmica, julga-se procedente tipificá-la como uma abordagem do sujeito africano, conforme aqui definido.

Mais uma vez, entretanto, cabe destacar como esta mesma tipificação continua difícil de construir, a partir da $H G A$, quando se trata de analisar artigos que citam a 
resistência ao Islã na África, seja na África Sudanesa ou no Magreb. Um caso exemplar deste silenciamento que vale comentar é a história dos Mossi e dos Bambara, durante os séculos XIV-XV. Tradicionalmente, se veem tais povos na história da África como aqueles que teriam oposto maior resistência à expansão islâmica. Sobretudo, por sua oposição militar ao avanço dos berberes, dos Songhai (islamizados) e dos Mali (islamizados), durante o período referido. Tal assunto, entretanto, não é valorizado na $H G A$. Pelo contrário, quando ele é citado, isto é feito para defender a tese contrária. Ou seja, de que tais povos, em verdade, não teriam sido hostis ao Islã. Daí J. Ki-Zerbo \& M. Izard (Do Níger ao Volta, Volume V) ao estudar o assunto defenderem que a historiografia deveria buscar, nesta temática, os interesses mútuos existentes entre os Mossi-Bambara e os muçulmanos ${ }^{42}$. Em síntese, assim como ocorreu com o Magreb, também em relação à África Ocidental não se observa na $H G A$ uma visão mais afirmativa do sujeito africano, que se construa a partir da resistência ao Islã.

É por isto que a história berbere como representante deste sujeito só volta a ser destacada quando ela é parte integrante da luta islâmica contra a Europa, a partir do século XII. É isto que se pode observar em diversos capítulos dos Volumes IV e V da obra. Nestes artigos se expõem como o Islã tornou-se uma ideologia importante para a formação do sujeito berbere, especialmente na África do Norte e Setentrional, entre os séculos XII e XVIII. Essa visão se inicia nos estudos sobre a civilização magrebiana, formada pela unidade política, cultural e social do Islã berbere-magrebiano. Para tais estudiosos, os fatos históricos que concretizaram tal unificação foram os movimentos dos Almorávidas e dos Almóadas que dominaram o Magreb e a Penísula Ibérica entre os séculos XI e XIII. No entanto, para entender a importância histórica destes movimentos é preciso contextualizá-los como ápice de um processo histórico mais longo de formação deste Islã, berbere-magrebiano.

A história deste Islã se inicia com o kharidjismo. O kharidjismo é uma ramificação do islamismo, nascido no século VII. Ele próprio é dividido em diversas

\footnotetext{
${ }^{42}$ Nas palavras dos autores:
}

Era um lugar comum muito difundido antes e após a conquista colonial dizer que os bambara e os mossi tinham elevado barreiras consideráveis contra o islã na África Ocidental. Trata-se de uma afirmação simplista que deve ser revista. (...) Resumindo, esta abertura recíproca (bambara, mossi e Islã) beneficiava largamente as duas partes envolvidas: ela associava os dirigentes muçulmanos ao poder, tomava vias endógenas para conduzir esses povos rumo a fé islâmica, mas também contribuía para reforçar o poder dos monarcas que, face à heterogeneidade étnica e social de seus Estados, não podiam se dar ao luxo de dissensões religiosas (Ki-Zerbo \& Izard, 2010, p. 430; p. 432). 
correntes, das quais o ibadismo e o sufrismo foram as mais importantes na história do Magreb. Como esclarecem M. El Fasi e I. Hrbek ( $O$ advento do Islã e a ascensão do Império Muçulmano, Volume III), tais correntes possuiriam alguns traços comuns. Elas insistiam na importância dos atos, além da fé, e afirmavam que qualquer um que se tornasse culpado de grave pecado era incrédulo e apóstata, merecendo a morte. Uma das suas principais doutrinas seria aquela que concernia ao imamado. Contrariamente a outros muçulmanos que consideravam o imamado (em outros termos, o califado ou devolução do poder) como prerrogativa exclusiva de algumas linhagens, os kharidjitas defendiam que todo homem, mesmo um escravo negro, poderia ser eleito à frente da comunidade muçulmana, caso possuísse as qualidades requeridas referentes à piedade, à integridade e ao saber religioso (El Fasi \& I. Hrbek, 2010a, p. 54). Essencialmente por estas tendências democráticas o kharidjismo teria ganho muitos adeptos entre os berberes magrebianos, que eram discriminados pelas correntes orientalistas dominantes do Islã. Em especial pela dinastia dos umayyadas, que haviam se tornado senhores da Península Ibérica com a ajuda berbere na primeira metade do século VIII.

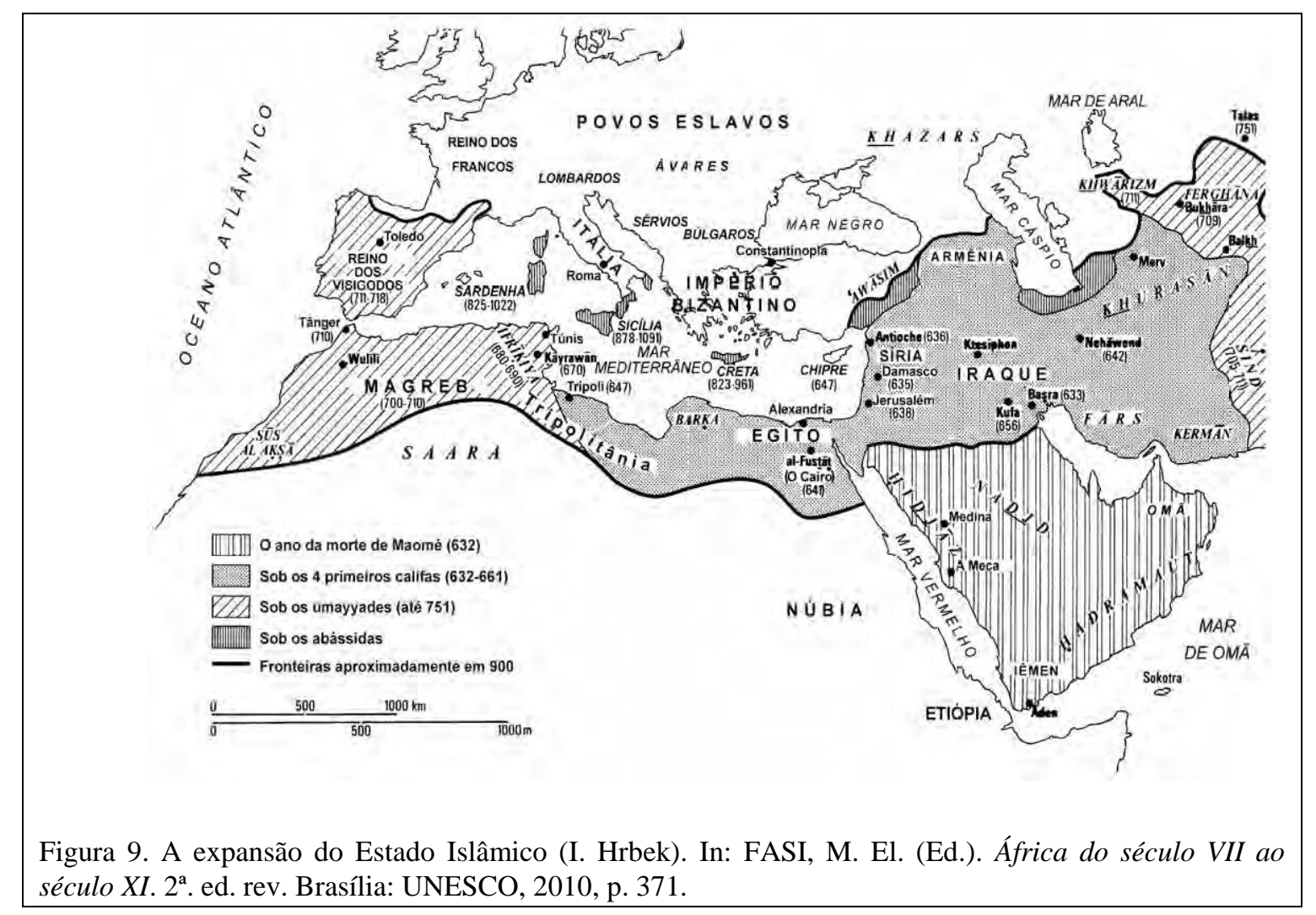


Como mostra M. Talbi (A independência do Magreb, Volume III), o kharidjismo foi a corrente islâmica predominante na luta pela independência dos berberemagrebianos contra esta dominação umayyada, que transformou a cena política norteafricana entre 740 d. C. e o século IX. Esta luta de independência foi inicialmente liderada pelo mercador berbere Maysara, tendo continuado com outras lideranças posteriomente (Talbi, 2010a, pp. 295-230). No entanto, como explica o mesmo autor, no século IX o kharidjismo deixou de ser a ideologia dominante no mundo berberemagrebiano, tendo perdido espaço para outras correntes e grupos islâmicos (alguns inimigos entre si), como os idrísidas, ibadistas, abássidas, aghlabidas e sufritas. Nesse quadro, a independência do Magreb, diz o autor, conquistada pelos berberes, foi marcada por uma luta intestinal entre os islâmicos, o que teria determinado a formação de vários reinos distintos e fragmentados entre os séculos VIII e IX, como os de Tāmasnā, Tlemcen, Sidjilmāsa, Tāhert, Fés, Ifrīkiya e outros (Talbi, 2010a, pp. 298$310)$.

Na medida em que Talbi narra a história da independência berbere-magrebiana, poder-se-ia imaginar que seria adequado examinar seu artigo como parte integrante da abordagem do sujeito africano na $H G A$. No entanto, assim como ocorre com outros artigos da obra do Volume III, este tema específico é analisado pelo autor como parte da história das disputas políticas internas entre as correntes islâmicas. Em suma, apesar do título do artigo (A independência do Magreb), o que se observa ali, de fato, é a complexa história da expansão do islamismo, que aparece como o verdadeiro sujeito da história. Apesar disto, este artigo é aqui citado porque narra os primeiros passos da unificação berbere-magrebiana. Esta sim, parte integrante da abordagem do sujeito africano $^{43}$.

Em relação aos Almorávidas e os Almóadas, no entanto, não há dúvida quanto a suas origens e interesses africanos ou, mais especificamente, berberes-magrebianos. A

\footnotetext{
${ }^{43}$ No mesmo sentido, pode-se ler o artigo relativo a história dos Fatímidas na HGA: I. Hrbek (Os fatímidas, Volume III). Os Fatímidas foram os primeiros unificadores da África Nordeste, do Egito ao leste magrebiano (até Ifrikiya), no século XIV. Em tese, portanto, poder-se-ia citá-los como parte integrante deste sujeito africano que se analisa. No entanto, com explica I. Hrbek no artigo citado, tal movimento deveria ser entendido como parte das lutas dinásticas de uma corrente específica do islamismo, o movimento ismaelismo (ramo dos xiitas), pelo controle político e ideológico do islamismo árabe. Daí que, mesmo contando com a participação decisiva dos berberes kutāma na formação do Império, as origens dos fatímidas, assim como seus interesses, ideologias, formas de organização político-social e líderes, fossem árabes e defendessem um governo árabe muçulmano na África (Hrbek, 2010d, p. 369-375). A partir da abordagem do sujeito africano, o mesmo pode-se dizer do artigo referente aos Impérios Aíubida e Mameluco no Egito, entre os séculos XI e XVI, estudados no seguinte artigo: J. Garcin. O Egito no mundo muçulmano (do século XII ao inicio do XVI), Volume IV.
} 
história dos almorávidas, na $H G A$, é objeto de um artigo específico de Hrbek \& J. Devisse (Os almorávidas, Volume III). Como explicam tais autores, os almorávidas foram um movimento religioso e político liderado por 'Abdallāh ibn Yāsīn; berbere oriundo da cabila de Djazūla, no sul marroquino. A razão primordial desse movimento, conforme os autores teria sido a tentativa de unificação dos sanhādja, um dos grupos berberes mais importantes do Oeste do Saara no século X. Neste contexto, os almorávidas fariam parte de uma luta maior e anterior deste grupo que, à época, se via alijado das melhores terras de pastagens e das principais rotas comerciais saarianas da região (para Sidjilmāsa e Awdāghust). Isto teria ocorrido porque tais terras e rotas estariam então dominadas pelos seus inimigos locais, os berberes zanāta, que haviam se aliado aos umayyades da Espanha (Hrbek \& Devisse, 2010, pp. 395-400).

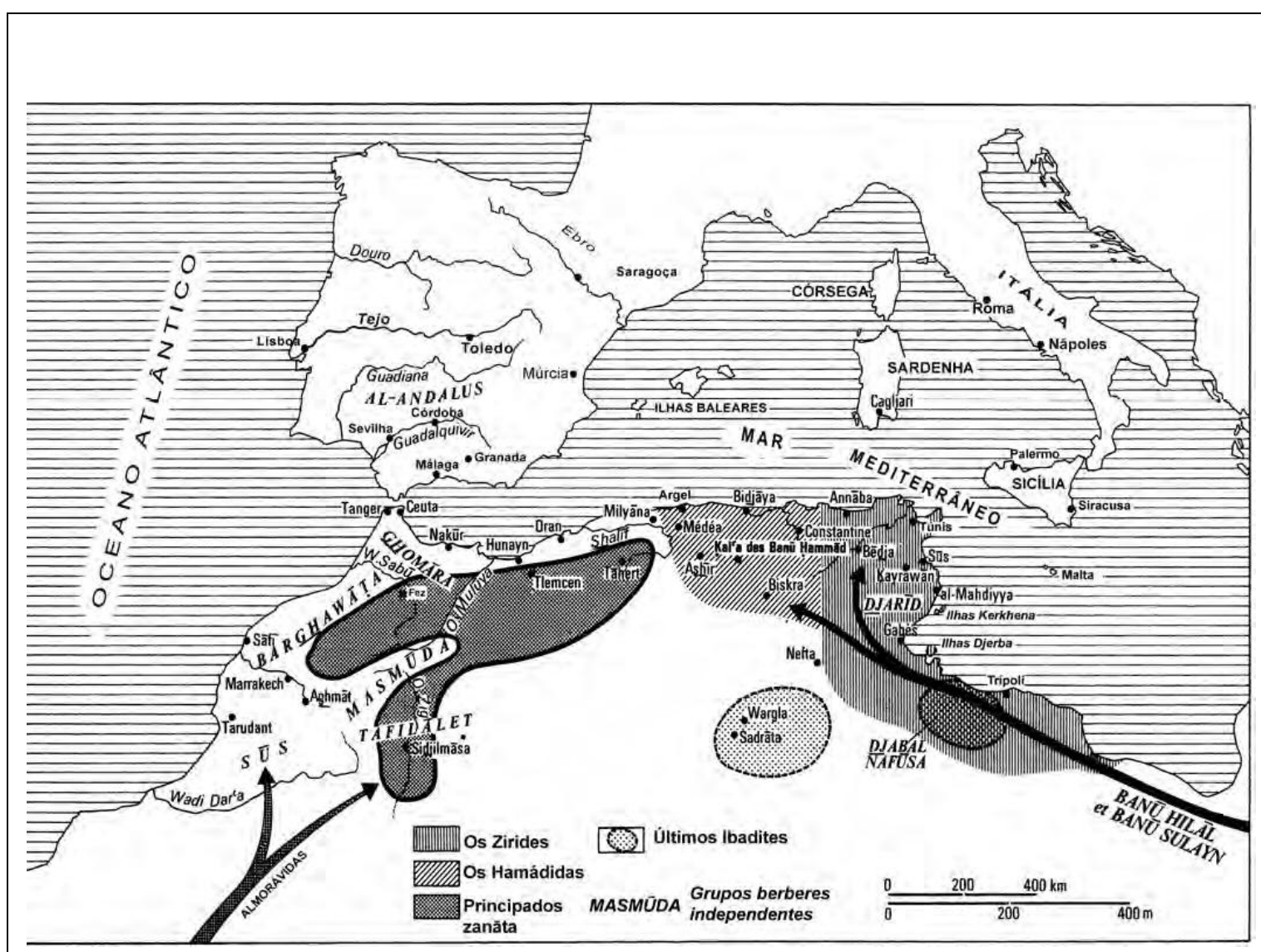

Figura 10. O Magreb na primeira metade do século XI (I. Hrbek). In: FASI, M. El. (Ed.). África do século VII ao século XI. 2a . ed. rev. Brasília: UNESCO, 2010, p. 371.

Neste contexto, os autores veem a adoção do islamismo (corrente sunismomalikista) entre os almorávidas, como um fermento ideológico importante nesta luta, 
visto que isto teria trazido unidade e disciplina aos sanhādja. Sob a liderança de Ibn Yāsīn e Abū Bakr ibn'Umar (seu sucessor), entre 1039 e 1069, os almorávidas conquistaram grande número de vitórias militares no Saara Ocidental e na Península Ibérica, contra outros grupos berberes e populações muçulmanas e cristãs. Assim, aquilo que originalmente não passava de um movimento local por reformas junto aos berberes sanhādja do deserto, tornou-se, em meio século, um império que conquistou todo o Magreb Ocidental (até Gana) e a Espanha. Tratar-se-ia, portanto, da primeira unificação do mundo berbere-magrebiano (Hrbek \& Devisse, 2010, p. 417).

Esta unificação, entretanto, só teria sido consolidada pelos novos conquistadores berberes do Magreb e da Península Ibérica no século XIII: os almóadas. Com estes, teria se consolidado o ressurgimento da civilização berbere-magrebiana, renovada pelo Islã.

Assim como os almorávidas, os almóadas foram um misto de movimento político e religioso. Este estaria ancorado no contexto berbere-magrebiano, mas seria também herdeiro das disputas entre as diversas correntes islâmicas. Para se observar a importância que a $H G A$ dá à experiência almóada, vale dizer que ela ocupa os quatro capítulos iniciais do Volume IV da obra (A África do século XII ao XIV). Tratam-se dos artigos de O. Saidi (A unificação do Magreb sob os Almóadas), M. Talbi (A expansão da civilização magrebina: seu impacto sobre a civilização ocidental), I. Hrbek (A desintegração da unidade politica no Magreb), H. Idris (A sociedade no Magreb após o desaparecimento dos Almóadas).

O artigo citado de O. Saidi trata das origens e da formação do Império Almóada. O movimento teria tido com ponto de partida a reforma religiosa liderada pelo mahd $\bar{\imath}$ Ibn Tūmart (1.075-1.130), nascido no Marrocos, pertencente ao grupo berbere dos Masmūda. Este teria se apoiado numa comunidade solidamente organizada, chamada de muwahhidūn (unitários ou unitaristas), para desenvolver um movimento político e religioso de dimensões continentais, contra os almorávidas. Do ponto de vista religioso tratar-se-ia de um luta por uma visão da unicidade de Deus ${ }^{44}$ e pelo retorno às fontes do Islã, em contraposição à suposta corrupção material e espiritual dos almorávidas. Politicamente, tratar-se-ia de um luta intra-berbere pelo controle das principais rotas do comércio transaariano e pela conquista e integração dos diversos pólos de desenvolvimento econômico do Magreb e do ocidente muçulmano (Saidi, 2010d: 17).

\footnotetext{
${ }^{44}$ Para um detalhamento das discussões teológicas aí envolvidas, ver o próprio artigo de O. Saidi. A unificação do Magreb sob os Almóadas, Volume IV, pp. 22-27.
} 
Estes objetivos foram alcançados com a conquista militar do Magreb e, finalmente, da Espanha, em 1.195. Tal conquista, entretanto, como mostra o autor, foi extremamente curta, tendo-se finalizado em 1.230. Desde então, o poder almóada ter-se-ia circunscrito a regiões cada vez menores, sendo corroído pelas reconquistas cristãs e pelas suas alianças com forças locais magrebianas, como os berberes Banū Ghāniya. Em fins do século XIII o Império estava exterminado.

Vale citar tais acontecimentos, para situar o leitor. No entanto, para além desta história militar é que se encontra o essencial da temática aqui levantada: a civilização berbere-magrebiana. Este tema específico é tratado no artigo de M. Talbi (A expansão da civilização magrebina: seu impacto sobre a civilização ocidental). Neste artigo, se defende a importância de uma visão de continuidade entre os almorávidas e almóadas, desde um ponto de vista civilizacional. Isto porque, diz o autor, se tais Impérios foram inimigos no campo político e religioso, nos demais planos da vida social - economia, arte, cultura, letras, filosofia, arquitetura, ciência - eles teriam sido substancialmente parecidos. Algo que seria especialmente perceptível nas regiões urbanas de intensa atividade cultural no Magreb (Fés, Ifrīkiya, Marrakech) e na Espanha Andaluza, em Sevilha, Córdoba e Granada (Talbi, 2010b, pp. 65-70).

Nestes casos, o autor diz que se poderia falar de uma civilização própria, iberomagrebiana. Para a formação desta teriam contribuído as populações berberes magrebianas, as populações negras ao Sul do Saara, os ibéricos e os italianos. Segundo o autor, nesta civilização, cultural e biologicamente mista, poder-se-ia ver a origem do Renascimento europeu do século XIV. Desta constatação, ele conclui o seguinte: "no século XII, a chama da cultura africana, em sua forma andaluzo-magrebina, brilhou pela última vez, antes que sua luz, cada vez mais vacilante, se extinguisse na obscuridade da decadência" (Talbi, 2010b, p. 77).

Após a queda dos almóadas o Magreb se divide em três dinastias e reinos independentes: a) os Haféssidas (1228-1574), que tiveram Tunis por capital; b) os Zaianidas (1235-1554), que governaram em Tlemcen (Tilimsan); c) Marínidas (12301472), instalados no Marrocos. No entanto, como diz I. Hrbek ( $A$ desintegração da unidade política no Magreb), tirante o início dos governos Haféssidas e Maríndas, tratar-se-ia, aí, de uma situação de decadência civilizacional marcada por instabilidade política, estagnação econômica e crises ecológicas. Quanto mais, se comparada ao crescimento paralelo da Europa mediterrânica à mesma época (Hrbek, 2010e, pp. 111$115)$. 
O tema da decadência, aliás, é o assunto dominante nos demais artigos da $H G A$ sobre o Magreb, não apenas neste Volume particular (IV), mas também no próximo Volume (V), que trata do período entre os séculos XVI e XVIII. Nos artigos de I. Hrbek (A desintegração da unidade política no Magreb) e H. Idris (A sociedade no Magreb após o desaparecimento dos Almóadas), o tema primordial é entender tal fato histórico nos séculos XII e XIII, colocando-o em paralelo ao fortalecimento da dominação europeia na região. Os dois fenômenos são vistos de forma inter-relacionada. Em especial, pela desigualdade dos termos de troca que se estabelece desde então entre as duas regiões. Todavia, se aponta também para causas internas dessa decadência do Magreb. Sendo as mais problemáticas, como já apontara Ibn Khaldun à época (século XIV): a) o colapso demográfico; b) o predomínio da vida nômade sobre a sedentária, acentuado com as invasões das populações árabes (Banū Hilāl, Banū Sulaym, Banū Ma'kil), a partir do século XI (Talbi, 2010b, p. 75; Idris, 2010, p. 117; Chérif, 2010a, p. 279).

$\mathrm{Na}$ medida em que, nestes e outros artigos o tema da decadência civilizacional ganha destaque, não por acaso, a abordagem do sujeito africano desta região desaparece do Volume V da obra, que trata do período histórico entre os séculos XV e XVIII. Ele será retomado apenas no Volume VI, que trata do século XIX. Neste caso, entretanto, já se trata de um sujeito africano moldado pela luta anti-colonialista, contra a dominação europeia. Voltaremos a este assunto. Todavia, antes disso, cabe analisar como a abordagem do sujeito africano, durante os séculos XVI e XIX, se mantém forte, na $H G A$, desde um ponto específico: a exaltação da luta negra nas diásporas.

\subsection{As diásporas africanas (VII-XX)}

Um dos temas importantes em que a abordagem do sujeito africano é utilizada na $H G A$ é o estudo da participação ativa que os africanos e seus descendentes tiveram em sociedades de outros continentes. Em síntese, as diásporas africanas. Este assunto é alvo de cinco capítulos específicos na obra: Y. Talib. A diáspora africana na Ásia, a partir de uma contribuição de F. Samir (Volume III); J. Harris. A diáspora africana no Antigo e no Novo Mundo (Volume V); F. Knight. A diáspora africana, com contribuições de Y. Talib e P. Curtin (Volume VI); R. Ralston. A África e o Novo 
Mundo; com a contribuição de F. Mourão (Volume VII); J. Harris. A África e a diáspora negra, com a colaboração de S. Zeghidour (Volume VIII).

Antes de se prosseguir nesta análise, entretanto, uma questão teórica necessita ser examinada. Se definimos a perspectiva africana, na $H G A$, como uma interpretação que privilegia os fatores internos ao continente, em oposição aos externos, na explicação histórica, científica, da África, faz sentido ver as diásporas africanas como parte desta história internalista da África?

Nossa resposta é que sim, mas cabe uma explicação mais pormenorizada sobre o assunto. A definição dada sobre a perspectiva africana fala em fatores internos e externos na explicação histórica. Estes fatores, por sua vez, são vistos como elementos essenciais, que explicariam a dinâmica histórica do continente. No caso da abordagem do sujeito africano, trata-se, sobretudo, a ação política deste contra os colonialismos antigos e modernos.

A partir de tais parâmetros é verdade que não faria sentido entender as diásporas africanas como um fator de entendimento da história da África. Afinal, tal fenômeno histórico não é algo essencial à dinâmica histórica do continente africano. Pelo menos, desde uma interpretação internalista desta história. Assim sendo, aparentemente, poderse-ia afirmar que não faz sentido tratar das diásporas africanas neste trabalho. No entanto, seguindo a própria $H G A$, deve-se concluir pelo contrário. Isto ocorre porque, nesta obra, as diásporas africanas são analisadas enquanto parte constituinte da abordagem do sujeito africano. Especialmente, como se verá a seguir, na medida em que elas seriam parte integrante da experiência histórica dos africanos de resistência e luta contra o colonialismo: no caso das diásporas africanas, contra os "colonialismos internos" a cada país americano. É, pois, uma nova face desta mesma história, que é anterior e posterior ao tráfico escravista atlântico. Daí que, neste estudo, analisar-se-á as diásporas neste último capítulo, pois ela é parte de uma ação política, tida como essencial à compreensão da história da África. 
Para isto, faz-se necessário, inicialmente, analisar a conexão histórica entre dois fenômenos correlatos: tráfico escravista e diásporas africanas. Afinal, o segundo foi, fundamentalmente, uma decorrência do primeiro ${ }^{45}$.

Uma contribuição interessante da $H G A$ para esta temática é destacar a antiguidade das relações entre tráfico escravista e diásporas na história da África. Evidentemente, este não foi um fato relativo apenas ao continente africano. O comércio escravista era uma prática comum em outros locais e tempos históricos. Por exemplo, no Mediterrâneo Oriental, no último milênio a. C., se comerciavam cativos de diversas origens (hebreus, egípcios, núbios, gregos, macedônios, cretenses, persas, etíopes etc). Sobre esse assunto, aliás, vale lembrar, como o fazem os autores da $H G A$, que o próprio termo para designar "escravo" na Europa Ocidental (sklave, slave, esclavo, escravo etc) deriva do etnônimo através do qual diversos povos eslavos da Europa Oriental foram designados. Ou seja, muito provavelmente também eles foram alvos da escravização dos europeus; pelos menos, no primeiro milênio da presente Era (Hrbek, 2010b, p. 18).

Em relação à África, sabe-se que populações do continente foram comerciadas como escravos desde os tempos do Egito Faraônico e da Núbia antiga. Este comércio ganhou certa amplitude com a decadência do primeiro destes Impérios, subjugado pelos romanos. Os cartagineses também comerciavam escravos africanos para o Mediterrâneo. Ademais, existia um comércio internacional no Oceano Indico, desde fins do último milênio, que incluía a costa leste do continente e o Mar Vermelho. Neste, participavam mercadores árabes, indianos, indonésios, chineses e africanos, cujo contingente aumentou consideravelmente depois da formação de Axum (século III d. C). Esse comércio também incluía escravos, entre outros bens. Apesar dessa longa história, como mostra Y. Talib (A diáspora africana na Ásia, a partir de uma contribuição de F. Samir, Volume III), não resta dúvida que esse comércio escravista antigo era ainda incipiente, se comparado ao que vai se fortalecendo após a consolidação do mundo muçulmano, desde o século VII d. C (Talib \& El-Samir, 2010, pp. 825-830). É a partir desta época, portanto, que, na $H G A$, se consolida a correlação

\footnotetext{
${ }^{45}$ Fundamentalmente porque as diásporas africanas também são fruto de viagens voluntárias de africanos para outras partes do mundo. No século XIX, em particular, sabe-se que muitos africanos livres viveram em diversos países do "Mundo Atlântico". Entre eles, especialmente, comerciantes, eclesiásticos e marinheiros. Apesar disto, não resta dúvida de que as diásporas africanas não são fruto destes casos particulares, mas de um intenso e dramático tráfico escravista de caráter internacional, atlântico e transaariano. Conforme dados de J. Inikori (2010, p. 100), este tráfico, só entre 1500 e 1890, escravizou uma quantidade em torno de 20 milhões de africanos e africanas, que foram levados para outras partes do mundo. Essa, pois, é a causa essencial das diásporas.
} 
entre tráfico escravista e diásporas, como pertencentes à abordagem do sujeito africano $^{46}$. A figura abaixo trata destas correntes do tráfico escravista pré-atlântico.

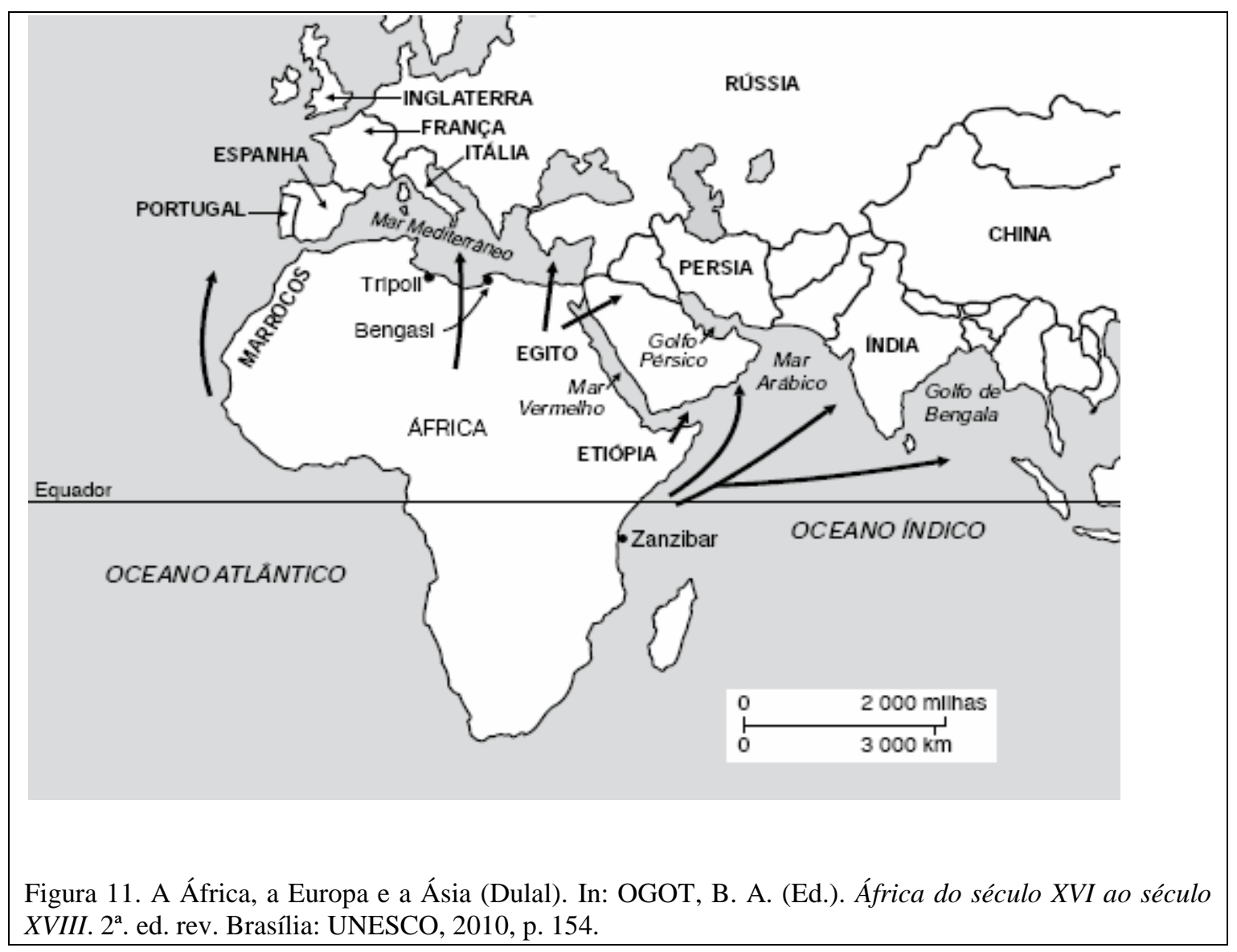

O artigo citado de Talib é a primeira fonte de informação mais pormenorizada sobre o tema. Estudando o período pós-muçulmano o autor mostra as diversas redes comerciais, pelo interior do continente africano ou pela costa leste até o Mar Vermelho e o Mediterrâneo, por onde se realizava o tráfico escravista da África para a Ásia (sobretudo Oriente Médio) e Europa. Como sempre, não se trataria aí de uma relação de mão única. É sabido que soberanos sudaneses em peregrinação também compravam escravos para as cortes no mercado do Cairo, um dos mais cosmopolitas do mundo nos séculos XI e XII. Em especial, artistas e músicos (Niane, 2010a, p. 5). Não seria impossível que alguns destes fossem europeus ou árabes, visto que a escravização era generalizada no Mediterrâneo no primeiro milênio da presente Era. No entanto, não

\footnotetext{
${ }^{46} \mathrm{~A} H G A$, portanto, com exceção do artigo citado de Diop (A origem dos antigos egípcios, Volume II), não traz uma abordagem do sujeito africano das populações deste continente que na pré-história ou na Antiguidade poderiam ser identificadas como "negras". Tal enfoque, evidentemente, ampliaria a abordagem do sujeito africano, conforme aqui delineada.
} 
resta dúvida de que se tratava, essencialmente, de um comércio com rota e direção específica: exportação da mão-de-obra africana para o Oriente Médio.

Esmiuçando tal história, mostra Talib que, na literatura árabe medieval, existiriam quatro termos para designar os africanos da África Sul-saariana. São eles: a) $s \bar{u} d \bar{a} n$, termo geral que se aplicaria a todos aqueles de pele negra, independentemente do lugar de origem; b) habash, em relação aos etíopes; c) zandj, que designaria basicamente os povos de língua banta da costa oriental da África; d) $n \bar{u} b a$, em relação aos núbios. Destaca o autor que conforme este comércio aumentava e se difundia no Oriente Médio, entre os séculos VII e VIII, mais o termo zanj teria ganho destaque. Daí que ele teria se tornando à época sinônimo de "negro" e de "escravo", trazendo uma identificação direta entre as duas ideias (Talib \& El-Samir, pp. 836-840).

A razão deste fato leva diretamente à discussão sobre o sujeito africano. Em primeiro lugar, porque ele mostra a importância que a costa leste africana passou a ter no fluxo deste tráfico escravista, medieval. Em segundo, porque a generalização deste termo, segundo autor, deveu-se também ao sentimento anti-negro dominante no mundo árabe após as "Revoltas dos Zanj” (689-90; 694; 749-50; 765; 869-83), que marcaram a história da região nos séculos VII e VIII (Talib \& El-Samir, 2010, p. 854).

A história destas Revoltas ainda é pouco conhecida. Elas foram, majoritariamente, lideradas e executadas por escravos provindos da costa leste africana que haviam sido trazidos ao Oriente Médio visando à preparação dos solos locais para a agricultura. Em particular, na Baixa Mesopotâmia e na Pérsia Meridional, nos séculos VII e VIII ${ }^{47}$. Todavia, segundo o autor, a mais importante destas revoltas teria sido liderada por um árabe chamado Alī ibn Muhammad, conhecido como o "Senhor dos Zandj”. Tal revolta, ocorrida entre 869-883, chegou a formar um Estado Zanj no Iraque. No entanto, ela foi derrotada após várias expedições militares enviadas pelo califado abássida (Talib \& El-Samir, 2010, p. 854).

A história dos Zanj faz parte da abordagem do sujeito africano, na $H G A$. No entanto, vale destacar que, em verdade, Y. Talib dá pouco espaço em seu artigo para a análise de tais revoltas (quatro páginas). Ademais, ele o faz sem valorizar de fato tal

\footnotetext{
${ }^{47}$ Neste trabalho, os escravos seriam empregados, em grupos de 500 a 5.000 , para livrar o solo de seu revestimento nitroso, no intuito de liberar terras aráveis destinadas ao cultivo (talvez da cana-de-açúcar), bem como para extrair e amontoar o salitre da camada superficial do solo. Seu trabalho era vigiado por intermediários e contramestres. A vida nas salinas teria sido particularmente deplorável (Talib \& ElSamir, 2010, p. 846).
} 
ação política. Seu artigo informa sobre o assunto, mas não traz uma visão afirmativa sobre ele. Em suma, é uma abordagem fraca desse sujeito africano.

O mesmo tipo de interpretação é trazida pelo autor quando se refere ao papel cultural dos africanos no mundo árabe medieval. Neste item são trazidas informações importantes e pouco conhecidas sobre o assunto, citando indivíduos de origem africana que teriam se destacado como literatos, músicos, poetas, teólogos etc, nesta parte do globo. Entretanto, trata-se, mais uma vez, apenas de uma informação útil. Ela não traz ou implica uma valorização explícita e afirmativa desta participação. Daí ter-se falado de uma abordagem fraca do sujeito africano.

É interessante queo mesmo pode ser dito de outros artigos da $H G A$ sobre as diásporas africanas quando eles se referem a tais diásporas na Europa e na Ásia. Por exemplo, a primeira e a terceira parte do artigo de J. Harris. A diáspora africana no Antigo e no Novo Mundo (Volume V) relata a presença africana na Europa, (especialmente na França e na Inglaterra) e na Ásia, entre os séculos XIV e XV. Neste texto o autor mostra como os africanos (e seus descendentes) teriam ali vivido tanto como escravos quanto livres nas mais variadas funções sociais: soldados, carpinteiros, serviçais domésticos, servidores, profissionais liberais etc. Destacam-se, sobretudo, as figuras que possuíam funções sociais mais elevadas. Este é o caso, por exemplo, do general francês Alexandre Davy Dumas (1762-1806), que era filho de francês com uma negra, escrava. Todavia, mais uma vez, fora o fato destes serem "negros", não se retira daí maiores elementos interpretativos quanto ao assunto (Harris, 2010, pp. 139-140).

Essa narrativa muda quando se trata de analisar a participação dos africanos e dos afro-descendentes na formação da América, a partir do século XVI. No próprio artigo citado de Harris, por exemplo, quando o autor passa a estudar tal assunto, também há uma parte informativa que enumera as funções sociais dos africanos na América - destacando algumas personalidades desta diáspora -, e o tratamento dos europeus em relação a eles. Todavia, a parte substantiva e afirmativa do seu artigo trata da história da diáspora enquanto busca pela liberdade dos africanos e seus descendentes, contra os escravismos americanos.

Neste sentido, o autor distingue duas formas de luta, entre os séculos XVI e XIX. A primeira delas, mais generalizada, teria sido a afirmação da liberdade plena e da africanidade, em que as resistências armadas teriam sido pioneiras - como nos quilombos e na Independência do Haiti. A segunda teria sido a crença de que esta liberdade e salvação só poderiam ser alcançadas pela assimilação dos valores e dos 
ideais europeus. Algo que se poderia observar, por exemplo, nas Igrejas cristãs organizadas pelos negros. Diz o autor que se tratariam aí de lutas distintas, mas com o mesmo objetivo. Por isto elas deveriam ser vistas como faces de uma mesma resistência africana, contra os escravismos americanos (Harris, 2010, p. 146).

Apesar de tais esforços, diz o autor, no século XIX, os africanos da diáspora teriam percebido que permaneceriam como párias em terra estrangeira, embora estes já tivessem, nesta época, transformando-se substancialmente do ponto de vista cultural. Por este fato eles teriam se conscientizado que sua condição de deserdados seria uma consequência direta de seu pertencimento a uma raça e cultura próprias. Deste sentimento, diz o autor, teriam surgido as primeiras tentativas de organização comunitária para salvar o povo negro e sua herança. Tratar-se-ia de uma unidade psicológica que teria sido umas das origens do movimento pan-africano dos séculos XIX e XX (Harris, 2010, p. 153). Cito o próprio:

De fato, a natureza de tal tráfico e suas consequências, mais especificamente na América e nos Caribes, levaram os africanos a travarem lutas por sua liberdade. Essas lutas, com o passar do tempo, despertaram nas consciências a preocupação generalizada da redenção da África e da libertação dos negros do mundo inteiro. Esse processo constituiu-se no início da época moderna e demonstrou, por volta de 1800, uma real influência em escala mundial. De fato, Toussaint Louverture apareceu, nesta ocasião, como um símbolo internacional da liberdade dos negros. Apesar da dominação colonial, tal processo seguiu seu curso, tratando-se provavelmente da mais importante consequência histórica da diáspora africana (Harris, 2010, p. 163).

Este condicionamento da "dominação colonial" na Américas é também levantado em outros artigos sobre as diásporas negras na $H G A$. Nestes, a força de tais diásporas é, geralmente, avaliada de acordo com a demografia e a estrutura de dominação europeia (economia, filosofia social, disciplina jurídica, normas comportamentais etc), além da marca maior ou menor da presença ameríndia. De um modo geral destaca-se que onde os africanos foram quantitativamente em maior número, mais fortes eles teriam sido em autonomia e poder de transformação das sociedades americanas nas suas mais variadas esferas (Knight, Talib \& Curtin, 2010, p. 888).

Ainda assim o quadro geral dessa dominação, como é sabido, não proporcionava formas de inserção coletiva em tal estrutura de dominação. Ainda que, como lembra F. Mourão, essa é uma ideia geral que precisa ser analisada particularmente, conforme a 
realidade histórica de cada uma destas sociedades (Mourão, In: Ralston, 2010, p. 910 ${ }^{48}$ ). Por esta mesma razão, F. Knight exalta, apesar de tudo, a participação africana na América:

\begin{abstract}
As realizações individuais e coletivas dos afro-americanos foram notáveis, no decorrer do século XIX. Malgrado as vias divergentes seguidas pela África e pelas Américas, apesar da monumental incapacidade da qual padeciam nos planos jurídico e social, mesmo com as suas enormes desvantagens econômicas, em que pese $\mathrm{o}$ agressivo antagonismo dos americanos de raça branca, os africanos lograram com sucesso criar comunidades em toda a extensão do continente americano (Knight, Talib \& Curtin, 2010, p. 901).
\end{abstract}

O tema se complexifica no estudo das diásporas entre a segunda metade do século XIX e início do século XX. É o assunto do capítulo assinado por D. Ralston ( $A$ África e o Novo Mundo, com contribuição de F. Mourão, Volume VI). Aí, o autor aponta como este sujeito africano, anti-colonial, se integra nas redes diaspóricas da época em estudo. Seu ensaio aponta para cinco momentos desta história: a) movimentos de retorno dos negros a África ou emigração dos negros da América do Norte, das Antilhas e do Brasil, para diversas regiões da África; b) evangelismo americano, com a ida de missionários afro-americanos para a África; c) repetição da rota África-Indias Orientais, sob a forma de uma corrente de estudantes africanos que se matriculavam em escolas e universidades americanas para negros; d) o movimento Pan-africanista, revestido de diversas formas (conferências, criação de organismos, atividades educativas, literárias e comerciais), que puseram africanos em contato com o mundo negro das Américas e vice-versa; e) persistência e transformação dos valores culturais africanos na América Latina e nas Antilhas (Ralston \& Mourão, 2010, pp. 876-877).

As observações acima mostram que os artigos que tratam do tema das diásporas africanas na América, na $H G A$, revelam um caráter mais afirmativo do sujeito africano, do que quando se trata das diásporas na Ásia e na Europa. Evidentemente, trata-se de uma diferença amparada num fato objetivo, de que as diásporas africanas na América foram muito maiores quantitativamente, do que nos outros continentes. Mas há também uma questão qualitativa. Parece que a existência de um Outro determinado (os

\footnotetext{
${ }^{48}$ Neste caso, na medida em que se especificou no título do artigo (A África e o Novo Mundo. Richard Davis Ralston, com a contribuição do professor Fernando Augusto de Albuquerque Mourão para as seções consagradas a América Latina e as Antilhas) a parte escrita pelo colaborador, é possível citá-lo sem incorrer em erro. No entanto, este procedimento não foi o usual na HGA. Por este motivo, em geral, não foi possível este tipo de citação específica, em outros artigos escritos em co-autoria ou colaboração.
} 
escravismos coloniais), é algo que possibilita uma visão mais afirmativa desse sujeito africano. Tal constatação reforça a hipótese de que, na $H G A$, a abordagem do sujeito africano se torna mais afirmativa na medida em que ela se concretiza como um ato de resistência determinado.

Esta percpeção é reforçada no último artigo referente à diáspora africana desta seção, também escrito por J. Harris (A África e a diaspora negra, com a colaboração de S. Zeghidour, Volume VIII). Aí, o movimento pan-aficanista é especialmente analisado, enquanto o fenômeno mais importante das diásporas negras, no século XX.

Nesse contexto, ganham detaque na obra alguns pioneiros do movimento panafricanista: J. Horton (Serra Leoa), E. Blyden (Antilhas), W. E. Du Bois (EUA) e M. Garvey (Jamaica). J. Harris interpreta o movimento pan-africanista como o cume de um processo secular de conscientização do povo negro, na África e na diáspora, acerca da sua necessária libertação coletiva. A África e a diáspora seriam, assim, duas faces de um mesmo fenômeno histórico-social. Um fenômeno que se poderia sintetizar nas ideias de liberdade e integração, consagradas pelos pan-africanistas. Cito o próprio:

Estas relações (entre a África continental e as suas diásporas), sobreviventes aos tráficos escravistas em direção a Ásia, Europa e Américas, foram consolidadas pelas experiências psicológicas e sociais da diáspora, de onde nasceram os movimentos de protesto, as revoltas e as ações internacionais conduzidas em prol da libertação dos negros, da liberdade e igualdade dos africanos e dos seus descendentes, no continente e no estrangeiro. (...) A ideia de um "salvamento" da África, a provocar a emancipação dos negros e demonstrar a sua capacidade, tanto em se autogovernar, quanto em contribuírem para a civilização mundial, impôs-se fortemente na diáspora e provocou $\mathrm{o}$ nascimento dos movimentos negros internacionais de libertação. (...) estas tentativas de libertação processadas na África e na diáspora culminaram, entre 1900 e 1935, no movimento pan-africanista (Harris \& Zeghidour, 2010, p. 850).

Para continuar esta luta, Harris aponta para um possível ressurgimento do panafricanismo como ideologia de massas na África e nas diásporas africanas. Esse fato, todavia, dependeria de uma nova geração de lideranças africanas e afro-descendentes, libertadas da educação colonial. Segundo o próprio autor:

A maioria dos Estados africanos não existe, é notório, senão desde aproximadamente uma geração, eles deveram enfrentar uma infinidade de problemas em uma época durante a qual a vida e a morte, o sucesso e o fracasso, exigiam decisões a serem tomadas com urgência. Por outro lado, os dirigentes africanos, em sua maioria, 
haviam realizado os seus estudos em ambiente colonial, receberam as rédeas do poder das mãos dos antigos colonizadores os quais, embora pródigos em conselhos, buscavam proteger-se contra qualquer veleidade de afirmação racial ou preservarem-se frente a possíveis sanções contra os responsáveis pela exploração a qual os povos africanos foram submetidos. Com a chegada de uma nova geração de dirigentes, na África e na diáspora, com uma melhor apreciação acerca do patrimônio comum aos africanos, bem como sobre a sua situação social e histórica, certa e indubitavelmente, novas tentativas surgirão no sentido da criação de laços estruturais duráveis entre a África e a diáspora. Assim sendo, o século XXI verá não somente a constituição de uma potente economia africana tirar proveito do conhecimento e da competência reunidos na diáspora, mas igualmente verá o conjunto das comunidades de origem africana reconhecer-se na esfera de influência pan-africana (Harris \& Zeghidour, 2010, pp. 871-872)

Em suma, colocando-se com um otimismo desconcertante, a perspectiva panafricana trazida por Harris vê o futuro como algo em aberto, ainda possível de ser transformado pela ação política dos indivíduos e das massas africanas e das diásporas. A luta faz o sujeito! Não há melhor ilustração para a abordagem do sujeito africano do que esta afirmação.

\subsection{As resistências africanas contra o colonialismo e o neo-colonialismo (XIX - $\mathbf{X X )}$}

Apesar do que foi dito até agora, a abordagem do sujeito africano, na $H G A$, só encontra seu ápice no Volume VII da obra, que trata de fins do século XIX e início do XX (até 1935). Aí, vê-se tal sujeito ressurgir como ator da resistência contra o colonialismo europeu.

Pode-se sintetizar esta resistência africana, na $H G A$, no século XIX, em três grupos primordiais. O primeiro grupo seria aquele formado por soberanos africanos que teriam se destacado como reformadores, buscando se contrapor à influência e domínio crescente dos europeus na África, até 1880. Este é caso de personagens como Muhammad 'Alī, no Egito (Abdel-Malek. O renascimento do Egito, 1805-1881, Volume VI), Teodoro II e Johannès IV, na Etiópia (R. Pankhurst. A Etiópia e a Somália; em colaboração com L. Cassanelli, Volume VI) e Radama I e Ranavalona I, em Madagascar (F. Mutibwa. Madagascar, 1800-1880; em colaboração com F. Esoavelomandroso, Volume VI). Em comum, eles teriam buscado utilizar-se das 
técnicas (sobretudo armas de fogo, indústrias) europeias para se contrapor aos próprios europeus, unificando seus países e desenvolvendo-os materialmente.

Nesse contexto, vale citar G. Uzoigwe que, no artigo Partilha europeia $e$ conquista da África: apanhado geral (Volume VII) dá uma interpretação interessante deste fenômeno modernizador, que bem tipifica a abordagem do sujeito africano. Diz o autor que as reformas do século XIX, comandadas pelos soberanos africanos, é que teriam precipitado a conquista militar do continente, acordada na Conferência de Berlim (1884-85). Na medida em que esta interpretação traria o lado africano na pré-história do colonialismo, G. Uzoigwe julga que ela possibilitaria uma visão menos eurocêntrica sobre o assunto, do que a trazida pelas teorias tradicionais. Afinal, estas enfatizariam apenas os fatores internos à própria Europa Ocidental (diplomáticos, psicológicos ou econômicos), para explicar o colonialismo do século XIX (Uzoigwe, 2010, p. 31).

O segundo grupo aqui ressaltado, a partir da $H G A$, é formado pelos soberanos africanos que se contrapuseram à efetiva colonização do continente, entre fins do século XIX e início do XX. Neste caso, na $H G A$, se evita dividir, neste grupo, soberanos que decidiram confrontar militarmente os colonialistas (Samori Touré [Mandinga], Ahmad Urabi [Egito], Muhammad Ahmad ibn Abdallah, o Mahdi [Sudão], Menelik [Etiópia], Cetshwayo [Zulu], Kabarega [Bunyoro], Sayyid Muhammad [Somália] etc) de outros que tentaram negociar com eles (Ahmadu Uma [Tukolor], Mwanga [Buganda], Prempeh [Ashanti], Tofa [Gun] etc). Isso ocorre porque, como afirma A. Boahen, na Introdução ao Volume VII da obra, tanto uns quanto outros teriam buscado o mesmo objetivo: a soberania e independência africana. Daí que não faria sentido classificar tais soberanos, como "resistentes" e "colaboradores". Em suas próprias palavras:

Assim, os dirigentes africanos, na sua maioria, optaram pela defesa de sua soberania e independência, diferindo nas estratégias e nas táticas adotadas para alcançar esse objetivo comum (...). Cumpre insistir nesta questão da estratégia, pois ela foi grosseiramente desfigurada até o presente, de forma que já se classificaram alguns soberanos africanos como "colaboradores", qualificando sua atividade como "colaboração". Somos contrários ao emprego do termo "colaboração", pois, além de inexato e pejorativo é eurocêntrico. Conforme ja vimos, a soberania era o problema fundamental em jogo entre os anos de 1880 e 1900 para os dirigentes africanos e, quanto a isso, está bem claro que nenhum deles se prestava a fazer acordos. Os dirigentes africanos qualificados erroneamente como colaboradores eram aqueles que estimavam que a melhor maneira de preservar sua soberania ou mesmo de recuperar a soberania acaso perdida em proveito de alguma 
potência africana, antes da chegada dos europeus, não consistia em colaborar, mas antes em se aliar aos invasores europeus. Por colaborador entende-se seguramente aquele que trai a causa nacional unindo-se ao inimigo para defender os alvos e objetivos deste último ao invés dos interesses de seu próprio país. Ora, como ja vimos, todos os africanos se viam confrontados com o problema de abandonar, conservar ou recuperar sua soberania. Tal era o objetivo daqueles que ligaram sua sorte a dos europeus, sendo inteiramente falso qualificálos de colaboradores (Boahen, 2010c, p. 11).

O terceiro grupo da resistência africana, apresentado no Volume VII da obra, são as massas populares. Para além da ação dos soberanos africanos, uma série de artigos da $H G A$ trata da resistência ao colonialismo na África, entre 1880 e início do século XX, como parte um sujeito africano mais amplo, que se concretizou na luta das etnias, intelectuais urbanos, proletários, camponeses, comunidades de Igrejas etc. É impossível, aqui, tratar detalhadamente deste assunto. Entrementes, ele é estudado nos seguintes artigos, do Volume VII da HGA: Iniciativas e resistências africanas no Nordeste da África (H. Ibrahim; em colaboração A. Ali); Iniciativas e resistências africanas no Norte da África e no Saara (A. Laroui); Iniciativas e resistências africanas na África Ocidental, 1880-1914 (M. Gueye \& A. Boahen); Iniciativas e resistências africanas na África Oriental, 1880-1914 (H. Mwanzi); Iniciativas e resistências africanas na África Central, 1880-1914 (A. Isaacman \& J. Vansina); Iniciativas e resistências africanas na África Meridional, 1880-1914 (D. Chanaiwa); Madagascar de 1880 a 1939: iniciativas e reações africanas a conquista e a dominação coloniais (M. Esoavelomandroso).

Um resumo das premissas em que se baseiam essas análises das resistências africanas ao colonialismo como fenômeno de massa, se encontra em T. Ranger (Iniciativas e resistências africanas em face da partilha e da conquista colonial, Volume VII). Neste artigo, Ranger observa que as pesquisas recentes sobre o assunto teriam comprovado três verdades históricas: a) a não resignação dos africanos à conquista europeia; b) a racionalidade das resistências africanas; c) a magnitude e importância histórica de tais resistências (Ranger, 2010, p. 52). Ademais, diz o autor, longe de serem algo referente apenas ao mundo urbano, relacionado à ação dos intelectuais e do proletariado nascente, ter-se-ia mostrado que tal resistência teria sido heterogênea e generalizada. Algo que se teria comprovado nas pesquisas sobre essa temática. Em particular, àquelas que estudaram o papel central que as ideologias 
religiosas (em particular, o Etiopismo ${ }^{49}$ ) e certos líderes tradicionais, tinham para a resistência africana nos espaços rurais, entre fins do século XIX e início do XX (Ranger, 2010, pp. 52-65). Por outro lado, novas temáticas sobre a "ordem moral", a "resistência econômica" e a "resistência indireta", por exemplo, teriam ampliado o estudo destas três prerrogativas anteriores (Ranger, 2010, p. 72). De fato, de um modo geral, pode-se dizer que este pressuposto de uma resistência heterogênea e generalizada é o dominante na abordagem do sujeito africano, nos artigos acima citados do Volume VII.

Sobre este assunto vale destacar que, na $H G A$, a adoção deste enfoque sobre a diversidade de tal resistência não traz a problemática se tais resistências poderiam ser, de fato, formas de ação que não se enquadrariam na luta anti-colonial. Afinal, pode-se imaginar, por exemplo, que algumas dessas ações fossem motivadas por sentimentos étnicos ou religiosos, independentes do colonialismo. Aliás, esse é um tema que Ranger aponta como um dos assuntos em debate na historiografia sobre a resistência na África, para além da $H G A$ (Ranger, 2010, p. 66). Nesta obra, entretanto, tal assunto não é abordado.

No entanto, mesmo assim, é possível afirmar que a $H G A$ fornece uma resposta interessante a tal problemática, que merece consideração. Ela é apresentada no artigo de E. Atieno-Odhiambo (Política e o nacionalismo na África oriental, 1919-1935). O argumento deste autor é que, na África Oriental, teria existido uma consciência em torno da luta anti-colonial, para além da diversidade de posições e formas da resistência africana da época (1919-1935). Todavia, apreender este fato dependeria de um conhecimento internalista da África. O autor recorre a um termo kiswahili para explicar tal fato na África Oriental: siasa. Originalmente, diz ele, este termo significaria ao mesmo tempo oposição, reivindicação, agitação e ação militante. Todavia, na experiência da resistência africana deste período tal termo teria se tornado sinônimo de resistência ao colonialismo em suas variadas formas. Daí que, para o autor, poder-se-ia definir a siasa, nesta época, como uma consciência coletiva dos malefícios do sistema colonial, em dado lugar e momento. Vale citar o autor:

\footnotetext{
${ }^{49}$ Como mostra K. Opoku (A religião na África durante a época colonial, Volume VII) este era apenas um dos nomes atribuídos às Igrejas cristãs autóctones, por vezes ditas "independentes" "separatistas" ou "em ruptura". Elas seriam resultado de uma iniciativa exclusiva dos africanos para formar um novo tipo de cristianismo, adaptado à visão africana do mundo. Estas Igrejas atraíram milhares de fiéis, desde fins do século XIX, e muitas se tornaram centros de atividade anti-colonialista. Ademais, essas igrejas proporcionavam a seus membros uma alternativa para os seculares serviços dos curandeiros e adivinhos, ainda que, se necessário, as pessoas continuassem a consultar os médicos tradicionais (Opoku, 2010, p. 624).
} 
A siasa representa, portanto, uma consciência coletiva dos malefícios do sistema colonial em dado lugar e momento. O termo abrange ao mesmo tempo a consciência de clãs, de nacionalidades e de classes sociais. As atividades politicas a que se dedica este capitulo embasavam-se, portanto, numa consciência de grupo concreta. Eram atividades de massa. Cada movimento exigia um chefe, mas eram as massas que o formavam, sendo os dirigentes apenas a vanguarda. $\mathrm{Na}$ sequiência deste capitulo ter-se-a em mente que cada movimento e cada dirigente tinha as massas atrás de si. E, de acordo com o nível e o terreno de intervenção escolhidos, algumas dessas atividades foram mais tarde classificadas como manifestações de nacionalismo (Atieno-Odhiambo, 2010, p.759).

Em suma, para este autor, a existência da siasa demonstraria a unidade anticolonialista da resistência africana, para além de sua heterogeneidade. Trata-se de um tipo de argumento interessante para a abordagem do sujeito africano, enquanto unidade na diversidade. Ademais, ele aponta para o segundo tema fundador do sujeito africano na passagem do século XIX para o XX: os nacionalismos africanos.

Há um debate na $H G A$, baseado em estudos específicos, se a resistência africana ao colonalismo deveria ser vista como um expressão de "proto-nacionalismo" ou não. Como observa Ranger (2010, pp. 64-66), este é um tema importante na historiografia sobre esta época. Para esta pesquisa, entretanto, tal discussão é secundária. Afinal, independente de ser expressão (ou não) de um mesmo conteúdo, o que aqui interessa é analisar como tais lutas (de resistência anti-colonialistas e nacionalistas) representam elementos de uma mesma abordagem da perspectiva africana: o sujeito africano.

Neste sentido, vale destacar que, na $H G A$, há uma tendência predominante de considerar os nacionalismos africanos como um movimento mais de elites do que foi feito em relação às resistências africanas ao colonialismo. Sobre este assunto fala B. Oloruntimehin, no artigo “A política e o nacionalismo africanos, 1919-1935 (Volume VII). Este autor, em verdade, busca criticar tal ponto de vista. Para isso, enumera outros fatores que teriam sido importantes para o nascimento dos nacionalismos africanos. Em especial, a suposta importância do descontentamento e dos sentimentos anticolonialistas nas zonas rurais no Entre-Guerras (Oloruntimehin, 2010, p. 661). No entanto, seu estudo, assim como os de outros autores, reitera, por fim, a importância que as elites intelectuais urbanas teriam tido para o surgimento dos nacionalismos africanos. Como diz o próprio: 
Em quase todos os casos, os movimentos nacionalistas e a política colonial correspondente foram conduzidos e dominados pelas novas elites educadas, que estavam em melhor situação para compreender a cultura política europeia e, portanto, para reagir de maneira competente aos regimes coloniais, de acordo com os termos desses mesmos regimes (Oloruntimehin, 2010, p. 666).

Este tipo de escrita da história, dominante na explicação das origens dos nacionalismos africanos, recupera, portanto, uma perspectiva mais individualista da abordagem do sujeito africano, recorrente quando se estudou a ação dos soberanos reformadores do século XIX. Trata-se de uma reorientação da escrita da história voltada para a ação das massas populares, que se fortificou na história da resistência africana ao colonialismo entre fins do século XIX e início do XX.

Dessa forma, nessa história mais recente dos nacionalismos africanos, volta-se a destacar a importância do indivíduo como agente da transformação histórica. Isso é notável, por exemplo, nos estudos da primeira parte do Volume VIII, que tratam das independências nacionais africanas. Neste sentido, se enfatiza o papel central que as lideranças africanas e seus agrupamentos políticos tiveram na libertação de seus países. Os principaís nomes aí citados são os seguintes: K. Nkrumah (Gana), J. Nyerere (Tanzânia), G. al-Nasser (Egito), A. Sékou Touré (Guiné), M. Kadhaffi (Líbia), B. Bella (Argélia), A. Cabral (Guiné Bissau), H. Selassié (Etiópia), P. Lumumba (Congo), J. Kenyatta (Quênia), E. Mondlane (Moçambique), F. Houphouet Boigny (Nigéria).

Nesta constelação ocupam lugar central, na $H G A$, três líderes africanos: Kwame Nkrumah, Gamal` Abd al-Nasser e Julius Nyerere. Esta centralidade se dá porque, além da referência às suas trajetórias, também são analisados, de forma resumida, aspectos dos seus pensamentos teóricos e políticos. Isto ocorre nos seguintes artigos do Volume VIII: Pan-africanismo e libertação (E. Kodjo e D. Chanaiwa); "Procurai primeiramente o reino político" (A. Mazrui); Construção da nação e evolução dos valores politicos (J. Ki- Zerbo, A. Mazrui e C. Wondji; em colaboração com A. Boahen); Construção da nação e evolução das estruturas politicas (J. Elaigwu; em colaboração com A. Mazrui);Tendências da filosofia e da ciência na África (A. Mazruiet. al.);O Panafricanismo e a integração regional (S. Asante, em colaboração com D. Chanaiwa).

A partir de uma análise da trajetória destes (Nkrumah e Nyerere) e outros líderes africanos, E. Kodjo \& D. Chanaiwa (Pan-africanismo e libertação, Volume VIII), por exemplo, mostram como o pan-africanismo, após 1935, conseguiu se manter, apesar das divergências internas, como um movimento político relevante para a conquista das 
independências africanas no século XX. Sobretudo após o Congresso Pan-Africano de Manchester, em 1945, quando este movimento teria passado a ser hegemonizado pelas próprias lideranças africanas, especialmente K. Nkrumah e J. Nyerere. Também a Organização da Unidade Africana (OUA), fundada em 1963, é vista positivamente pelos autores, como uma instituição fundada em legítimos preceitos pan-africanos. Todavia, para estes, para derrotar o novo inimigo dos africanos e seus descendentes, o neo-colonialismo e o racismo, a OUA buscaria se comunicar, mais solidamente, com outras correntes do pensamento político internacional. Em particular, o terceiromundismo e o pan-arabismo (Kodjo \& Chanaiwa, 2010, pp. 902-910).

Essa visão positiva do pan-africanismo é baseada, segundo os autores, em fatos importantes do ponto de vista histórico, como a vitória dos africanos contra o colonialismo europeu, no século XX. Aí, o pan-africanismo teria tido um papel central como ideologia de massas, permitindo a unificação da luta anti-colonial e a formação de uma rede de solidariedade aos países africanos e seus descendentes da diáspora (Kodjo \& Chanaiwa, 2010, p. 924).

Apesar deste fato, é certo que os autores não deixam de destacar as dificuldades que o mesmo pan-africanismo teria tido como uma força integradora dos próprios países africanos. O assunto é pormenorizadamente debatido no artigo de S. Asante (O Panafricanismo e a integração regional (em colaboração com D. Chanaiwa, Volume VIII). Neste texto, o autor mostra como a ideologia pan-africana não conseguiu se firmar como projeto de integração da própria África, após as independências nacionais. Sobretudo porque a concretização deste projeto de unidade dependia da disposição dos dirigentes e lideranças africanas para caminhar conjuntamente no longo prazo. Algo difícil de se realizar na medida em que estes estariam, à época, mais preocupados com a consolidação de suas independências nacionais, recém conquistadas. E, desde tal perspectiva, viam tal projeto de unidade como algo impositivo e desorientador (Asante, 2010, p. 876).

No entanto, apesar de tais dificuldades, os autores que tratam especificamente da temática pan-africana na própria África (Asante, E. Kodjo e D. Chanaiwa) acreditam que este movimento continua sendo o cerne da ação política africana no mundo contemporâneo. Isso porque, a equação básica do pan-africanismo (libertação e integração) só ter-se-ia realizado de fato em sua primeira etapa. A segunda etapa, relativa à integração continental, mal teria se iniciado. É apenas com a realização 
concreta desta etapa, medida por organizações regionais e federalistas que, para tais autores, poder-se-ia caminhar para a superação da dependência neo-colonial na África.

S. Asante, no artigo citado (O Pan-africanismo e a Integração Regional; em colaboração com D. Chanaiwa, Volume VIII), historiza algumas tentativas de construção de tais alternativas. Entrementes, como diz o próprio autor, além das divergências políticas de época - como as que opunham o Grupo de Casablanca ao Grupo de Monróvia ${ }^{50}$ na década de 1960 -, a permanência da África no sistema internacional teria comprometido o progresso do regionalismo no continente. Por isso, segundo ele, nos dias atuais grande parte da cooperação econômica regional não atenderia aos interesses dos países africanos, mas àqueles dos organismos de ajuda estrangeiros, dos consultores e das empresas transnacionais. Este seria o caso de instituições como a SADCC, da UDEAC e da CEAO $^{51}$, cujos principais beneficiários da integração regional seriam os centros fornecedores da ajuda, das técnicas e dos investimentos estrangeiros (Asante, 2010, p. 893).

Conclui o autor que a cooperação econômica constituiria a espinha dorsal da autonomia coletiva na África e não poderia ser eficazmente utilizada como instrumento de desenvolvimento regional enquanto os países participantes não tivessem realmente o domínio dos setores-chave da economia ou dos recursos que alimentam os projetos comuns. Nesse contexto, se reitera que só esta via levaria à formação de uma estrutura autônoma dos países africanos, fundada na cooperação pan-africana (Asante, 2010, p.

\footnotetext{
${ }^{50}$ Explicação do próprio autor:
}

Em 1961, Gana, Guiné, Egito, Mali, Marrocos, Líbia e o governo argelino no exílio constituíram o Grupo de Casablanca, ao passo que outras antigas colônias francesas, acompanhadas da Nigéria, da Etiópia, da Libéria e de Serra Leoa, formavam o Grupo de Monróvia. De modo geral, o Grupo de Casablanca era favorável a uma forte união política, inspirando-se nos Estados Unidos da África, conclamados por Nkrumah. Ele reunia aqueles dirigentes africanos militantes do pan-africanismo, do socialismo e do não alinhamento, preconizando uma planificação e um centralizado desenvolvimento econômico, um sistema de defesa e de segurança em esfera continental, além de defender a restabelecimento da honra da cultura africana.

O Grupo de Monróvia, por sua vez, era favorável a uma confederação "maleável" de Estados africanos, soberanos e independentes, que favorecesse uma participação e uma cooperação voluntarias no âmbito dos intercâmbios culturais e da interação econômica. Os seus membros eram particularmente inflexíveis no tocante ao respeito pela soberania e a integridade territorial de cada Estado, desconfiando das ambições de certos Estados do Grupo de Casablanca e antevendo uma possível ingerência em seus assuntos internos (Asante, 2010, p. 877).

${ }^{51}$ Comunidade Econômica da África do Oeste (CEAO), União Aduaneira e Econômica da África Central (UDEAC), Southern African Development Coordination Conference (Conferência para a Coordenação do Desenvolvimento na África Austral, SADCC) (Asante, 2010, pp. 878 -887). 
893-894). Tais mudanças, entretanto, não poderiam ser realizadas sem reformas radicais na política interna dos países africanos. Em suas palavras:

Finalmente, e seja qual for a estratégia adotada para superar o estado de dependência, a prioridade devera ser concedida às reformas de política interna. Tais reformas exigem disciplina e sacrifício. Nós, africanos, naquilo que nos compete, devemos aceitar a disciplina, a moderação e a austeridade necessárias à instauração daquilo que se poderia chamar a nova ordem interna, caso, um dia, pretendamos transformar as relações de dependência permanente, por nós mantidas junto aos países industrializados, em laços de interdependência benéficos que desencadeariam, no seio da sociedade africana, o motor necessário a um crescimento econômico perene (Asante, 2010, p. 895).

Independente de se concordar ou não com esta ideia do autor - a formação de uma "nova ordem interna" como passo primordial para a superação da situação neocolonial -, deve-se admitir que estamos aí em plena abordagem do sujeito africano. Afinal, é o ressurgimento deste sujeito, sob a premissa pan-africana, que possibilitaria a África retomar o seu destino. Sendo assim, a dependência do continente em relação à Europa é vista, pelo autor, mais como uma reciprocidade conveniente (entre elites, fora e dentro da África), do que uma determinação estrutural, do próprio sistema capitalista.

Essa não é, evidentemente, a única interpretação que se possa dar do problema da dependência africana. Todavia, é uma explicação recorrente e significativa na $H G A$, como parte da abordagem do sujeito africano. Mais especificamente, do sujeito panafricano. Esse é, desde um ponto de vista dialético, a síntese das duas experiências contemporâneas deste sujeito: as diásporas e as resistências africanas à dominação europeia (colonial ou neo-colonial).

\subsection{Considerações parciais}

Este capítulo analisou o que seria a abordagem do sujeito africano, na $H G A$, como uma face específica da perspectiva africana aqui estudada. Teoricamente, definiuse esta abordagem como uma explicação histórica que visa destacar a ação do sujeito africano, da forma mais ampla possível. Sobretudo, enquanto pólo político de 
resistência à dominação colonial e neo-colonial europeia. Uma visão hegemônica no Volume VII da obra.

Essa definição se confirmou no capítulo. No entanto, uma análise atenta desse objeto, permitiu desvelar a existência de uma abordagem mais ampla e rica deste sujeito africano, na $H G A$. Para examinar tal constatação, se definiu e investigou, no pormenor, a seguinte periodização: a) A experiência egípcio-faraônica (3.200 a. C. - 332 a. C; b) A civilização berbere-magrebiana (146 a. C. - XIV d. C.); c) As diásporas africanas (VII $\mathrm{XX}$ ); d) As resistências contra o colonialismo e o neo-colonialismo europeu (XIX e $\mathrm{XX})$.

A análise aqui realizada mostrou que esta abordagem do sujeito africano, na $H G A$, possui uma característica própria, que merece análise. Sua substância essencial, a ação política africana, se concretiza sempre em relação a um Outro, que não se mantém estático, podendo se corporificar em formas diversas. Em relação à experiência egípciofaraônica, se falou deste sujeito em oposição aos povos indo-europeus e outros (semíticos, gregos, "mediterrânicos" etc). Daí o Egito negro-africano, de Diop. O mesmo sobre a civilização berbere-magrebiana. Ela se forma como expressão de um sujeito, de origem diversa (púnica e líbia), que se concretiza na luta contra os novos invasores do Magreb: romanos, árabes, vikings, bizantinos, italianos, portugueses, espanhóis etc. O Islã se torna parte fundamental desta luta e se integra a tal história. O sujeito da diáspora, no mesmo sentido, se torna um sujeito, em última instância, por se opor aos escravismos americanos, dos europeus e seus descendentes. É por isto que uma visão mais afirmativa deste sujeito só se consolida quando se analisa as diásporas africanas na América. Explica também, por outro lado, a abordagem fraca do sujeito africano diaspórico, quando se tratou das Revoltas dos Zanj no Oriente Médio, nos séculos VII e VIII. Por fim, tratou-se da última etapa da periodização deste sujeito: a resistência africana ao colonialismo e ao neo-colonialismo. Aí, o inimigo é explícito: os europeus.

Essa síntese da investigação realizada mostra que há uma continuidade essencial desse Outro, que existe para além desta aparente heterogeneidade, que criou o sujeito africano. Esta continuidade parece ser uma ideia fantasmagórica da Europa e dos europeus. Afinal, eles são a oposição que cria o sujeito africano em sua diversidade, negra ou berbere-magrebiana. Daí o silencialmento da $H G A$ acerca da expressão colonial da expansão muçulmana na história da África. 
Tal constatação recoloca o problema de como pensar uma história descolonizada, pós-eurocêntrica. Afinal, que internalismo é este que continua dependendo de um Outro, para se afirmar? Entretanto, antes de responder a esta e outras perguntas específicas, analisar-se-á qual o tipo de história da África que surge do regionalismo da perspectiva africana, na $H G A$. 


\section{Capítulo 4: O regionalismo na história da África da $H G A$}

\subsection{Periodização}

Este capítulo sintetiza a história da África construída pela abordagem regionalista da perspectiva africana, na $H G A$. Por regionalismo, entende-se aqui um tipo de internalismo em que os autores enfatizam análises holísticas de longa duração em âmbito local, analisando os elementos fundamentais que explicariam a história de uma região africana, em particular. Tal tipo de abordagem tem por objetos de estudo primordiais, o ecossistema local (ou regional) e os desenvolvimentos (ou adequações) técnicos e sócio-políticos das populações africanas.

Esta abordagem é a terceira forma de escrita da história mais comum na $H G A$, superando apenas a explicação externalista. Todavia, a diferença quantitativa entre esta e a abordagem do sujeito, na $H G A$, é pequena.

Seguindo o capítulo anterior, esta investigação se baseia em uma periodização proveniente dos marcos temporais estabelecidos pela própria abordagem em exame. Nesse caso, portanto, uma cronologia que se julga estar de acordo com o exame do regionalismo na $H G A$. Para isto, dividir-se-á este capítulo em dois itens. São eles: a) Neolítico e África Antiga (10 mil - XII d. C; b) África entre os séculos XII-XIX.

\subsection{Neolítico e África Antiga (10 mil a. C. - XII d. C.)}

Os artigos que tratam de temas incluídos nesta periodização da história da África, desde uma abordagem regionalista, se encontram nos quatro primeiros volumes da obra. Para fundamentar tal abordagem, os artigos da $H G A$ estudam dois processos históricos importantes, em suas particularidades. O primeiro é o desenvolvimento e a especialização tecnológica das populações africanas. $\mathrm{O}$ segundo é a sedentarização de tais populações. Uma característica marcante do regionalismo da $H G A$ é entender estes 
dois processos de forma inter-relacionada e contínua no tempo, mostrando como ele ocorreu efetivamente em diferentes regiões ecossistemicas.

Em relação ao Neolítico e à África Antiga (até o século XII), vários temas são trazidos na $H G A$, para comprovar tal análise no período a. C. O exemplo maior que pode-se aí encontrar são os artigos que tinham por objeto de estudo das populações e sociedades do Vale do Nilo, tratando da especificidade histórica dos antigos egípcios e núbios.

Uma explicação regionalista típica, que abarca as duas civilizações pode ser encontrada, por exemplo, em linhas gerais, nos artigos de G. Mokhtar, em sua Introdução (em colaboração com J. Vercoutter) e Conclusão ao Volume II da obra (A África Antiga). Nestes textos o autor defende que as duas sociedades citadas, núbia e egípcia, derivariam de um mesmo espaço ecossistemico: o Vale do Nilo. Tal fato teria condicionado, segundo este autor, uma cultura material aproximada entre as duas regiões durante o Neolítico local, entre 9.000 e 3.500 a. C. (Mokhtar, 2010a, p. XXXV; em colaboração com J. Vercoutter). Neste sentido, o autor chega a falar de uma civilização única: egípcio-núbia (Mokhtar, 2010b, p. 860).

No entanto, diz Mokhtar, com o desenvolvimento do processo de sedentarização ocorrido durante este período histórico, as duas populações ter-se-iam diferenciado, produzindo modos de vida específicos. Para o autor, a questão essencial desta distinção teriam sido as cheias do Nilo, presentes no Vale do Nilo. Isto porque, segundo ele, tais cheias teriam impulsionado, no Egito, a formação de uma sociedade complexa, letrada e especializada, visando o controle deste fenômeno natural. Especialmente para a produção agrícola. Por outro lado, como isto não teria ocorrido na Núbia, no Baixo Vale do Nilo, aí ter-se-ia mantido um modo de vida aldeão, associado ao pastoreio e à pequena produção agrícola, até o último milênio a. C. (Mokthar, 2010a, p. LVII).

Não se trata aí de um determinismo geográfico, mas de um condicionamento. $\mathrm{O}$ próprio Mokhtar afirma que mais do que uma "dádiva do Nilo", o Egito foi uma criação dos homens e mulheres na medida em que foram eles os responsáveis pela formação desta civilização (Mokhtar, 2010a, p. XLVIII; Mokhtar, 2010b, p. 857). Mas não resta dúvida de que, para o autor, a explicação histórica do surgimento e consolidação destas civilizações está relacionada ao papel de condicionamento natural que o Vale do Nilo e suas sub-regiões teriam produzido. Isto desde o início destas sociedades, visto que o 
processo de sedentarização teria se intensificado após o ressecamento do clima na África. Em particular, a partir de 2.400 a. C (Mokhtar, 2010a, p. XXXIV) ${ }^{52}$.

Alguns artigos da obra trabalham especificamente com tais civilizações antigas. No caso dos egípcios, os artigos de A. Abu Bakr ( $O$ Egito Faraônico) e J. Yoyette $(O$ Egito Faraônico: sociedade, economia e cultura) oferecem análises detalhadas das características primordiais desta civilização africana em seu esplendor. O período de sua existência sob dominação grega e romana é apresentado por H. Riad \& Devisse $(O$ Egito na época helenística) e S. Donadoni ( $O$ Egito sob dominação romana). São ensaios informados que servem como exemplos de uma historiografia consolidada. A história dos núbios, por sua vez, é analisada pormenorizadamente em cinco artigos do Volume II da obra: S. Adam \& Vercoutter (A importância da Núbia: um elo entre a África Central e o Mediterrâneo), N. Sherif (A Núbia antes de Napata: 3100 a 750 antes da Era Cristã), J. Leclant (Império de Kush: Napata e Méroe), A. Hakem (A civilização de Napa e Méroe), K. Michalovsky (A cristianização da Núbia). O Volume III possui outro artigo importante sobre esta temática: S. Jakobielsky (A Núbia cristã no apogeu de sua civilização).

Entre os artigos citados, os mais tipicamente regionalistas são os de S. Adam \& J. Vercoutter (A importância da Núbia: um elo entre a África Central e o Mediterrâneo) e J. Leclant (Império de Kush: Napata e Méroe). No primeiro artigo, após certa tergiversação, defende-se que a história núbia deveria ser entendida em um contínuo temporal cujas origens remontariam ao quarto milênio a. C. Nesta época, para os autores, os núbios seriam uma população semi-sedentária, pastora e pesqueira, que vivia adequada ao clima úmido então prevalecente no Alto Vale do Nilo. Esta população teria se adensado com o início do ressecamento deste clima, por volta de 2.400 a. C. Nesta época, teria surgido uma nova cultura, chamada de "Grupo C", pelos arqueólogos. Sua origem, portanto, seria no próprio Vale do Nilo. A mesma origem regional é atribuida, um tanto vagamente, ao Reino de Cuxe (Kush) e sua capital: Querma (Kerma). Os autores não estabelecem uma relação direta entre o Grupo $\mathrm{C}$ e os cuxitas, mas postulam que são populações aproximadas, adaptadas à mesma sub-região: o Baixo Vale do Nilo (Adam, 2010, pp. 227-228; em colaboração com J. Vercoutter).

\footnotetext{
${ }^{52}$ Sobre este assunto, ver também outros dois outros artigos: J. Vercoutter. Descoberta e difusão dos metais e desenvolvimento dos sistemas sociais até o século V antes da Era Cristã, Volume I; Adam \& Vercoutter. A importância da Núbia: um elo entre a África Central e o Mediterrâneo, Volume II.
} 


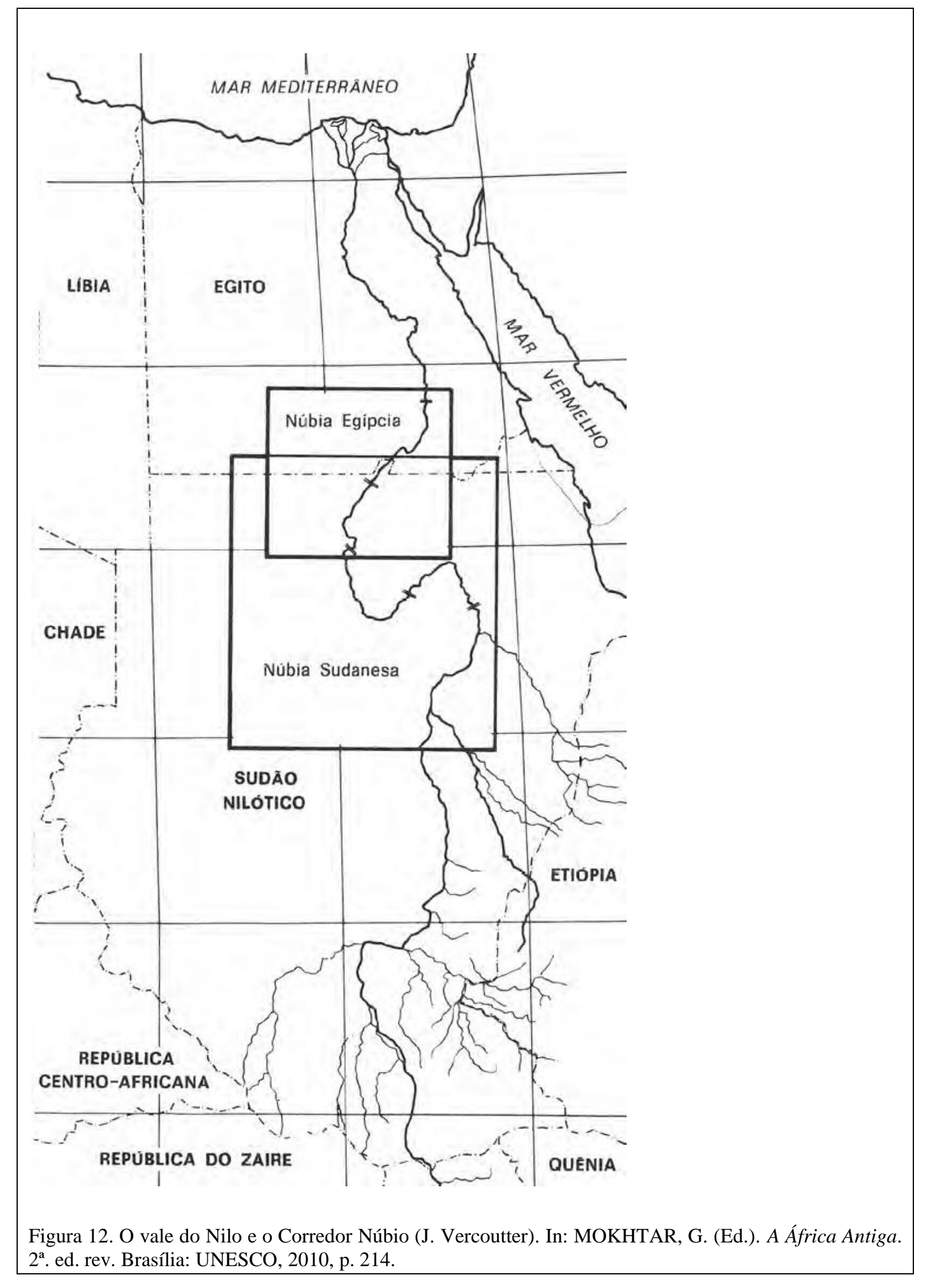


A perspectiva regionalista sobre o Reino de Cuxe é mais holística quando se trata de analisar a sua última capital, Méroe. J. Leclant (Império de Kush: Napata e Méroe), por exemplo, acredita que a prosperidade de Meroé, entre os séculos IV a. C e III d. C., teria derivado de motivos geográficos, climáticos e econômicos. Geográficos porque sua localização na Baixa Núbia teria permitido uma maior independência dos núbios em relação aos seus poderosos vizinhos do Norte: egípcios, persas, hicsos, gregos, romanos. Ademais, seria também uma zona de entreposto comercial, entre o Chade, o Alto Egito e o Mar Vermelho. Ecologicamente, porque a cidade estaria localizada em uma área de estepes, mais favorável à agricultura do que a Alta Núbia, rodeada de desertos. Somar-se-ia a isto o desenvolvimento tecnológico dos meroítas, como comprovaria seu pioneirismo no processamento do ferro na África sul-saariana, propiciado pela abundância de árvores e de arenito na região (Leclant, 2010, p. 283). Estão aí reunidos, na argumentação de Leclant, os elementos fundamentais da explicação regionalista: adequação a um meio ecossistemico favorável e desenvolvimento tecnológico. O comércio teria sido ali importante, mas não fundamental ${ }^{53}$.

O mesmo tipo de abordagem para a história da África Antiga, pode ser encontrado em artigos sobre diferentes partes do continente, nos Volumes I e II da $H G A$.

Sobre a África Central, os artigos mais interessantes neste sentido são os de V. Noten: a) Pré-história da África Central, parte II; em colaboração com P. Maret, J. Moyersons, K. Muya, E. Roche (Volume I); b) A África Central; em colaboração com D. Cohen e P. Maret (Volume II). Nestes, o autor busca problematizar a história tradicional da África Central, alicerçada na teoria dos movimentos populacionais advindos da África Ocidental e Oriental. Em especial, a expansão dos povos banto.

Para isto, destaca três pontos centrais. Em primeiro lugar, defende que, entre o Neolítico e a Idade do Ferro (Antiga e Recente ${ }^{54}$ ) não existiria uma ruptura, mas uma

\footnotetext{
${ }^{53}$ Para uma opinião contrária neste particular ver no Volume II, Ali Hakem \& J. Vercoutter e I. Hrbek. A civilização de Napata e Méroe. ${ }^{54}$ No mesmo sentido de "Primeira" e "Segunda" Idade do Ferro. Sobre o significado destes termos, ver
Vansina \& Devisse (A África do século VII ao século XII: cinco séculos formadores, Volume III):
}

No passado, construiu-se uma cronologia, que se esperava usar para todo o mundo negro, de duas idades sucessivas do ferro, a "segunda idade" aparecendo justamente durante os séculos aqui estudados (VII e XII).Tentara-se mostrar que diferenças significativas marcariam a passagem da primeira para a segunda idade: em particular, um aumento das quantidades produzidas, uma melhoria e diversificação das 
continuidade essencial das culturas neolíticas locais, cuja origem seriam as formas de adaptabilidade que as populações impuseram ao seu micro-ambiente específico, em busca do equilíbrio ecológico (Noten, 2010a, p. 636; Noten, 2010b, p. 693). Em segundo lugar, porque, segundo o autor, as novas datações da metalurgia na África Central, como a do sítio de Katuruka (500 a. C.), seriam anteriores à suposta chegada dos povos banto a região (Noten, 2010b, p. 711). Finalmente porque, nos poucos sítios que sugerem adensamentos populacionais no início da presente Era (como Sanga e Kototo, as margens do rio Lualaba), não se teria encontrado traços comuns de cerâmicas próprias à Idade do Ferro, em relação aos períodos anteriores. Pelo contrário, para Noten, a diversidade ali presente apontaria para uma heterogeneidade cultural, marcante na região desde os tempos neolíticos (Noten, 2010b, p. 708).

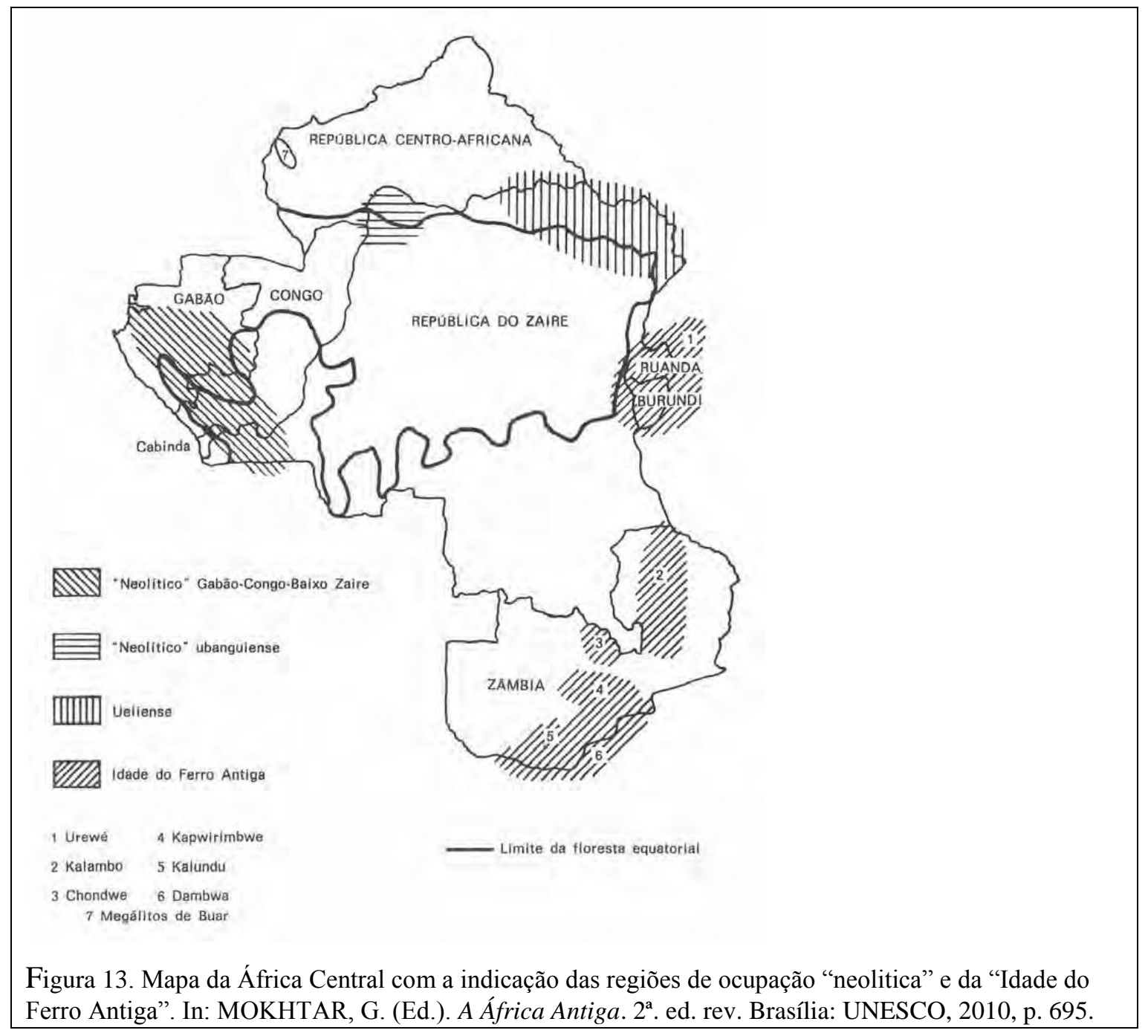

qualidades, bem como o surgimento de novos modos de instalação, que levariam a produção de cerâmicas 'características' (Vansina \& Devisse, 2010, p. 904). 
Como afirma o próprio Noten, suas colocações não possibilitam criar uma nova síntese da história regional. Mas os elementos aí levantados, que apontam para uma abordagem regionalista da África Central, problematizam a narrativa usual desta temática na história da África que se baseia, em particular, na expansão dos povos banto e suas supostas consequências históricas: difusão do ferro, produção agrícola, homogeneização cultural. Sobre este assunto, aliás, o autor traz uma crítica direta:

A interpretação antropológico-arqueológico-linguística, que associava a expansão das linguas bantu a difusão da metalurgia do ferro, condizia perfeitamente com a ideia da evolução a partir do Crescente Fértil, negando a África a possibilidade de invenções autonômas (Noten, 2010b, p. 711).

A crítica a tal visão difusionista (intra-fricana) da expansão banto não se restringe a este autor. Ela reaparece, por exemplo, diretamente, na seção final do artigo que trata especificamente deste tema: Lwanga-Lunyiigo \& Vansina. Os povos falantes de banto e sua expansão, Volume III. Aí, S. Lwanga-Lunyiigo ${ }^{55}$ defende que os povos banto (assim como a sua língua) não seriam originários da África Ocidental, mas da própria África Sub-Equatorial. Em verdade, diz o autor, eles seriam resultado da mescla de populações "negroides" (termo do autor) locais, que viviam nesta região da África havia milênios. Por esta razão, para Lwanga-Lunyiigo, a expansão banto, com todas as suas consequências, deveria ser entendida como um processo interno à própria África Sub-Equatorial, com vários séculos de duração. Vê-se aí mais um argumento regionalista em prol da origem local das populações banto.

Este aspecto de longa duração na explicação histórica é utilizado por diversos autores aqui classificados como regionalistas. Especialmente quando tratam da história

\footnotetext{
${ }^{55}$ A afirmação de que a referida seção do artigo é de autoria de S. Lwanga-Lunyiigo encontra-se na própria $H G A$, na seguinte passagem:

Nota do editor: Este capítulo, obra de dois especialistas de diferente formação científica, com opiniões divergentes, constitui, até certo ponto, um amálgama de ideias. Fato assaz surpreendente, os dois lograram um consenso no tocante as questões mais importantes, demonstrando assim que anos de frutuosas discussões puderam desdobrar-se em reais progressos relativamente ao problema banto. Somente um ponto de desacordo: a teoria avançada por um dos co-autores - S. Lwanga-Lunyiigo - cuja opinião difere daquela da maioria dos especialistas. Nós a exporemos aqui, tal como o próprio autor enunciou-a em sua contribuição original (Lwanga-Lunyiigo \& Vansina, 2010, p. 193).
} 
da África Antiga. Entre eles, deve-se destacar B. Wai-Andah, em sua abordagem da África Ocidental, em A África Ocidental antes do século VII (Volume II). Aliás, sua introdução ao artigo ilustra tal posicionamento de forma exemplar:

O exame crítico dos dados arqueológicos (e outros) de que dispomos não corrobora a ideia bastante difundida de que as origens, o desenvolvimento e o caráter geral das sociedades neolíticas e da Idade do Ferro da África ocidental decorrem sobretudo de fatores culturais externos. Em especial, é um erro afirmar que na maior parte dos casos as ideias e populações vindas do exterior - geralmente do norte, através do Saara - estimularam ou provocaram todos os grandes eventos dos primeiros tempos da produção alimentar ou do trabalho do ferro e do cobre. Os dados sugerem, antes, que fatores complexos de ordem regional, sub-regional ou local desempenharam um papel de importância variável; que os sítios do Neolítico e da Idade do Ferro na África ocidental podem ser compreendidos, em diferentes escalas, como partes constituintes de sistemas de sítios integrados, tanto quanto possível, com as principais condicionantes ecológicas em jogo (Wai-Andah, 2010a, p. 657).

Para referenciar esta hipótese o autor cita um conjunto de dados de diversas fontes: paleontológicos, botânicos, ecológicos, etnográficos e arqueológicos. Desta investigação conclui que os processos de sedentarização e desenvolvimento tecnológico na África Ocidental deveriam ser estudados a partir dos complexos de produção alimentar específicos desta região, formados ainda no Neolítico, a partir do VI milênio a. C. Estes complexos seriam a exploração do solo (plantio), o pastoreio e a exploração mista (combinação do cultivo e das atividades pastoris). No nível específico tais complexos difeririam segundo as espécies de plantas cultivadas, das raças de animais criadas, da maneira como se praticava a cultura e da criação, e dos tipos de povoamento e sistemas sociais adotados. Mas o autor aponta algumas plantas nativas comuns a estes complexos alimentares: o painço, o fônio, o arroz africano, leguminosas (como a ervilha-de-vaca e a ervilha-da-terra), tubérculos (como o inhame-da-Guiné), o dendezeiro e o amendoim (Wai-Andah, 2010a, p. 629) ${ }^{56}$.

Para Andah, portanto, a história da África Ocidental Antiga deveria ser vista como um processo longo de sedentarização, associado ao desenvolvimento heterogêneo de complexos alimentares locais. Seria inclusive em busca deste objetivo que os povos da região teriam transformado suas relações com o meio ambiente circundante aumentando o seu domínio sobre ele.

\footnotetext{
${ }^{56}$ Sobre este assunto particular ver também: T. Shaw. A zona guineana: situação geral. Volume III, pp. 538-544.
} 
É interessante notar que Wai-Andah é um dos poucos autores da $H G A$ que examina a formação destes complexos alimentares como um elemento fundante dos processos civilizatórios no continente ${ }^{57}$. Neste sentido, o autor analisa os primeiros adensamentos populacionais da África Ocidental (anteriores à Era Cristã), como Dhar Tichitt, Daima, Kintampo-Ntereso e Nok, em última instância, como consequências desse desenvolvimento de sistemas agrícolas específicos (Wai-Andah, 2010, p. 668).

Ao tratar desta temática o autor traz um argumento original à abordagem regionalista aqui tratada. Isto ocorre porque ao dar tal centralidade à investigação dos complexos agrícolas africanos como um elemento essencial da história do continente, Andah cria um modelo que une as duas pontas primordiais de tal abordagem: sedentarização e desenvolvimento tecnológico. Por esta razão, assim como Vansina (movimentos populacionais) e Devisse (economia mediterrânica), por exemplo, são autores essenciais quanto à abordagem difusionista intra-africana da $H G A$, Andah o é em relação à abordagem regionalista da história da África.

Esta discussão sobre a África Ocidental Antiga é uma pequena parte do que foi escrito na $H G A$ sobre esta região do continente desde uma abordagem regionalista. Isso é facilmente verificável nos artigos que tratam do tema, nos Volume IV e V da obra. Nestes, se constrói a história da África entre os séculos XII e XIX d. C. Mas o Volume III, que trata desta história até o século XII, possui outros artigos interessantes desde uma perspectiva regionalista, que devem ser citados. Estes retomam a tese fundamental dessa abordagem: estudar a formação das sociedades africanas (no caso, entre os séculos VII e XII) a partir de uma análise holística de longa duração, que visa estudar o processo de sedentarização e o desenvolvimento tecnológico das populações.

\footnotetext{
${ }^{57}$ Os complexos alimentares africanos são tema de um artigo específico da $H G A$ : R. Porters \& J. Barrau. Origens, desenvolvimento e expansão das técnicas agrícolas (Volume I). $\mathrm{O}$ ensaio é baseado nas contribuições pioneiras de N. I. Valivov e de R. Porters, sobre os berços agrícolas africanos. Mas o ensaio não dá consequiência às suas afirmações, no plano histórico. Como o tema é pouquissímo retomado pelos demais autores da $H G A$ trata-se de um tema sub-representado na obra. Do mesmo modo, deve-se observar que os autores da $H G A$ deram também pouca importância em suas interpretações históricas específicas aos elementos trazidos por análises de geo-histórica da África, como as que estão presentes em dois artigos no Volume I da obra: Geografia histórica: aspectos fisicos (S. Diarra) e Geografia histórica: aspectos econômicos (A. Mabogunje). Desde uma perspectiva metodológica, a importância das ciências naturais para a história da África é destacada nos artigos de T. Obenga (Fontes e técnicas específicas para a história da África, Volume I) e J. Ki-Zerbo (Os métodos interdisciplinares utilizados nesta obra, Volume I). Todavia, do mesmo modo, o tema não reverbera como poderia na escrita da história nos demais artigos da obra. Tal ausência enfraquece a abordagem regionalista da história da África, na $H G A$, em relação às demais.
} 
Um artigo generalista sobre esta temática é o de François de Medeiros: Os povos do Sudão: movimentos populacionais (Volume III). Embora o artigo verse sobre uma temática tipicamente difusionista intra-africana - os movimentos populacionais internos à África -, ele será incorporado ao regionalismo na $H G A$, porque seu conteúdo interpretativo, de fato, faz parte de tal abordagem. Trata-se de sua hipótese sobre o surgimento do Estado nas sociedades sudanesas no primeiro milênio da presente Era.

Esta hipótese é que a formação do Estado, no Sudão Ocidental e Oriental, teria sido uma criação própria dos povos sudaneses em época anterior à chegada dos mercadores árabes à região, no século IX. Para comprovar tal afirmação o autor se baseia em uma análise comparativa dos Estados de Gana e Kanem. Para Medeiros, tanto em um caso quanto no outro, a formação do Estado estaria associada à posse de duas formas de poder essenciais na África Ocidental no primeiro milênio da presente Era: a) instrumentos de ferro; b) emprego de cavalos e camelos. Diz o autor, que a posse destes elementos pelas elites locais na segunda metade desta Era é que teria permitido a formação de milícias e exércitos armados na região. Este seria um fator primordial que explicaria a origem dos Estados, pois, desde então, tais elites poderiam impor uma dominação permanente às pequenas unidades de agricultores e pastores do Sahel (Medeiros, 2010, p. 159).

Se tais fatores explicariam a origem do Estado, outros por certo explicariam a sua continuidade. A partir dos casos de Gana e Kanem, Medeiros diz que tal fato derivaria de outros dois fatores primordiais. O primeiro seria a instituição da realeza sagrada. Afinal, através desta, os reis tinham um elemento ideológico para perpetuar sua soberania por territórios vastos e povos heterogêneos. O segundo seria o controle centralizado das riquezas das sociedades que governavam. Em particular as riquezas minerais, como o ouro. Tal fato teria permitido aos soberanos sudaneses, durante séculos, comerciar de forma autárquica com os demais povos, como os berberes e árabes (Medeiros, 2010, p. 161).

Vê-se, portanto, que a partir dos casos de Gana e Kanem o autor busca destacar elementos regionais que explicariam a formação dos Estados Sudaneses. O mesmo objetivo é buscado em outros artigos da $H G A$ de forma menos generalista. E, portanto, mais tipicamente regionalistas.

Entre estes vale citar outro ensaio de B. Wai-Andah, no Volume III da obra, chamado A zona guineana: os povos entre o Monte Camarões e a Costa do Marfim (com colaboração de J. Anquandah). Neste texto, o autor defende que existiriam provas 
suficientes para se construir uma história regionalista da formação das sociedades complexas na área em estudo (zona guineana inferior), no primeiro milênio da presente Era. Isto porque para ele, no período referido, seriam fartos os elementos que comprovariam a evolução gradual das sociedades locais em seu meio ambiente, passando de pequenos vilarejos pré-históricos para conjuntos urbanos com complexos sistemas políticos, culturais, tecnológicos (difusão do ferro) e econômicos, que teriam se consolidado em fins daquele milênio.

Para comprovar tal fato o autor cita diversos elementos. O mais importante entre eles é a presença das cidades que floresceram gradualmente nesta região, na segunda metade do primeiro milênio d. C. Para Wai-Andah elas distinguir-se-iam das aglomerações antigas pelo seu relativo tamanho, composição e organização social. Ademais, elas estariam mais estruturadas em torno de um núcleo central e seriam mais povoadas que os aldeamentos antigos. Possuiriam também artesãos especializados. Estes estariam ocupados na produção de bens com a prática de diversas indústrias como o trabalho em metal, a fabricação de pérolas e a tinturaria. Outra marca distintiva destas cidades teriam sido os mercados, com posição estratégica e dispostos em intervalos próximos, em função dos recursos que faziam a sua prosperidade com o comércio regional, anterior à chegada dos árabes na região. O surgimento de tais cidades na zona guineana, na metade do primeiro milênio d. C, seria comprovado pelos vestígios arqueológicos das cidades de Bengho, Bono Manso e Ifé. Posteriormente, em fins deste primeiro milênio, teriam florescido outras cidades importantes como Igbo-Ukwu, Udo, Uromi, Ilesha, Benim etc (Wai-Andah \& Anquandah, 2010, p. 613).

Ao analisar tais cidades, Bassey Wai-Andah as aborda como fenômenos específicos de evolução social que englobariam desenvolvimento tecnológico, adequação ambiental, redes comerciais, ampliação do sistema cultural, estratificação e especialização do trabalho. Neste sentido, para o autor, o período entre 600-1.200 d. C. teria sido uma época fundamental, em que se teriam formado os contornos essenciais das sociedades na África Ocidental. Tais seriam ampliados posteriormente (Wai-Andah \& Anquandah, 2010, p. 575). Em suma, na medida em que a sociedade se torna complexa, se complexificam também os elementos envolvidos na explicação histórica. Algo que só tende a tornar mais verossímil a abordagem regionalista, aqui tratada.

O trabalho de F. Masao e H. Mutoro (A costa da África Oriental e as ilhas Comores, Volume III) é outro artigo que, tratando das origens da civilização shawili, utiliza uma ótica próxima à de Andah: busca entender a formação das sociedades 
complexas na África como um fenômeno interno e regional de longa duração. Para isso, os autores citados visam mostrar que a civilização swahili não teria sido decorrente da chegada dos árabes à região, como a historiografia colonial fazia crer, mas antes parte integrante da história das populações autóctones da África (banto ou afro-indonésios) e de sua interação com o meio ambiente. Em suas próprias palavras:

O objeto do presente capítulo consiste em tentar reconsiderar a história da costa oriental da África e das ilhas Comores, chamadas abaixo, para simplificar as coisas, costa oriental da África e seus arredores, entre os séculos VII e XI da Era Cristã.

Tal empreendimento visa corrigir o quadro errôneo proposto pelos historiadores e/ou arqueólogos da escola de pensamento colonial que, ao basearem-se em fontes externas e ao apoiarem-se em dados incompletos ou simples rumores, apresentaram uma síntese correspondendo, na maioria dos casos, a história dos comerciantes e colonizadores estrangeiros, considerados a origem da civilização da costa.

Obviamente, eles desempenharam um papel nos primeiros tempos da história da costa oriental da África, mas o fato de terem contribuído para a evolução ocorrida naquela época não significa que eles tenham impulsionado a sua evolução. Além de enriquecer a base de dados de que dispomos, as descobertas recentes atualizadas incessantemente graças a pesquisas sistemáticas baseadas em métodos científicos e novas técnicas nos domínios da arqueologia, da história, da etnografia, etc (os autores do presente capítulo referem-se notadamente aos seguintes trabalhos: J. de V. ALLEN, 1982; M. HORTON, 1981, H. W. MUTORO, 1979, 1982b ${ }^{58}$ ), estabelecem pouco a pouco que a história da costa oriental da África e de seus arredores é a história das populações autóctones da África e de sua interação com o meio ambiente (Masao \& Mutoro, 2010, p. 685).

Para clarificar as origens da civilização swahili, cujo ápice ocorreu no século XII, os autores remontam ao final do primeiro milênio da presente Era. Defendem eles que as recentes (fins da década de 1970 e início da de 1980) escavações arqueológicas realizadas nos sítios arqueológicos de Lamu, Pate, Manda, Aldabra, Gedi, Mwana, Ntwapa e Comores, trariam evidentes vestígios de assentamentos humanos. Nestes, a tradição cultural comprovaria que tais povoamentos seriam oriundos de uma população africana autóctone, ali estabelecida. A explicação para este fato, segundo os autores, seria que o conjunto dessa região (e seu interior próximo) seria à época caracterizado

\footnotetext{
${ }^{58}$ Allen, J. de V. (1982) “The "Shirazi”" problem in East African coastal history', Paideuma, 28, pp. 9-27; Mutoro, H. W. (1982) 'A survey of the Kaya settlement system on hinterland Kenya coast' (Report to the Ministry of Culture and Social Services, Governmentof Kenya); Mutoro, H. W. (1979) 'A contribution to the study of cultural and economic dynamics of the historical settlements on East African coast, with particular reference to the ruins of Takwa, North Coast' (University of Nairobi). O artigo citado de M. Horton (1981) não consta na bibliografia da $H G A$ e também não foi localizado por outras fontes.
} 
por um clima de monção. Portanto, à exceção do norte do Quênia e da Somália, gozaria de um bom regime de chuva, florestas e solos férteis, favoráveis às atividades agrícolas (Masao \& Mutoro, 2010, p. 687).

Aproveitando-se desse clima favorável, as populações locais teriam formado aldeamentos cada vez mais numerosos, baseados na produção agrícola e na pesca, na segunda metade do primeiro milênio d. C. Para os autores isto não significaria que tais cidades eram isoladas. Pelo contrário, no plano econômico elas formariam uma única sociedade costeira constituída por um conjunto homogêneo de comunidades urbanas e rurais (Masao \& Mutoro, 2010, pp. 712-715).

Sobre esta base, que formaria o núcleo originário da civilização swahili, teriam se adicionado os elementos provindos da chegada dos muçulmanos à região a partir do século IX. Sobretudo a difusão do islamismo e o aumento do comércio costeiro, com maior presença de produtos africanos. Para os autores, portanto, só a partir de então é que se poderia falar da influência muçulmana na civilização swahili. Por consequência, tal civilização seria originalmente africana. Algo que se poderia constatar da herança africana swahili, especialmente dos povos banto, em termos linguísticos, religiosos, econômicos e arquitetônicos (Masao \& Mutoro, 2010, p. 702) ${ }^{59}$.

Esta questão sobre a continuidade da herança banto nos swahili levanta um debate interessante para esta análise. O que distingue a abordagem regionalista das demais aqui estudadas não é necessariamente a busca que esta realiza das origens locais de sociedades africanas. Mas a importância que ela costuma dar a este fato. Isto ocorre porque, ao contrário da abordagem difusionista intra-africana, já analisada, o regionalismo julga que os elementos propulsores desta origem continuariam a ser fatores essenciais na explicação histórica destas sociedades mesmo após a influência de fatores extra-regionais - comércio internacional, islamismo etc. Em particular com relação ao desenvolvimento tecnológico e à organização de espaços de sedentarização, em que a produção agrícola veio se tornar dominante.

É esta a lógica de explicação que permite aos autores regionalistas realizarem análises internalistas e locais das sociedades africanas, em períodos mais recentes da história da África, em que o peso dos fatores externos torna-se cada vez mais presente. É isto que se verá no próximo item.

\footnotetext{
${ }^{59}$ Segundo J. Vansina (1993, p. 346) ocorreu uma mudança de autoria neste artigo. Originalmente, ele seria escrito por H. N. Chittick. No entanto, o Comitê da $H G A$ teria decidido alterar sua indicação, pois este autor teria defendido uma posição externalista sobre a temática, em que a civilização swahili era entendida como um fenômeno árabe-muçulmano.
} 


\section{3. A África entre os séculos XII-XIX}

O Volume IV da $H G A$ é o livro em que, em termos quantitativos, a abordagem regionalista encontra seu ápice. Isto é particularmente notável em relação à África Ocidental, entre os séculos XII e XIV. Aí, os textos tidos por regionalistas buscam comprovar como as dinâmicas históricas (direta ou indiretamante) resultantes dos fatores externos à África nesta época teriam sido, em verdade, elementos secundários na história da maioria das populações africanas. Isto, mesmo em relação àquelas populações que eram parte integrante de grandes Reinos e Impérios da época, como Mali, Songhai, Mossi, Akan, Ioruba, Haussa.

Entre esses fatores externos cabe citar dois primordiais, entre os séculos XII e XIV: o comércio transsaariano e o Islã. Ao realizar uma história da África para além destes elementos o regionalismo cria uma alternativa para a história tradicional da África desta época, de caráter difusionista intra-africano ou externalista.

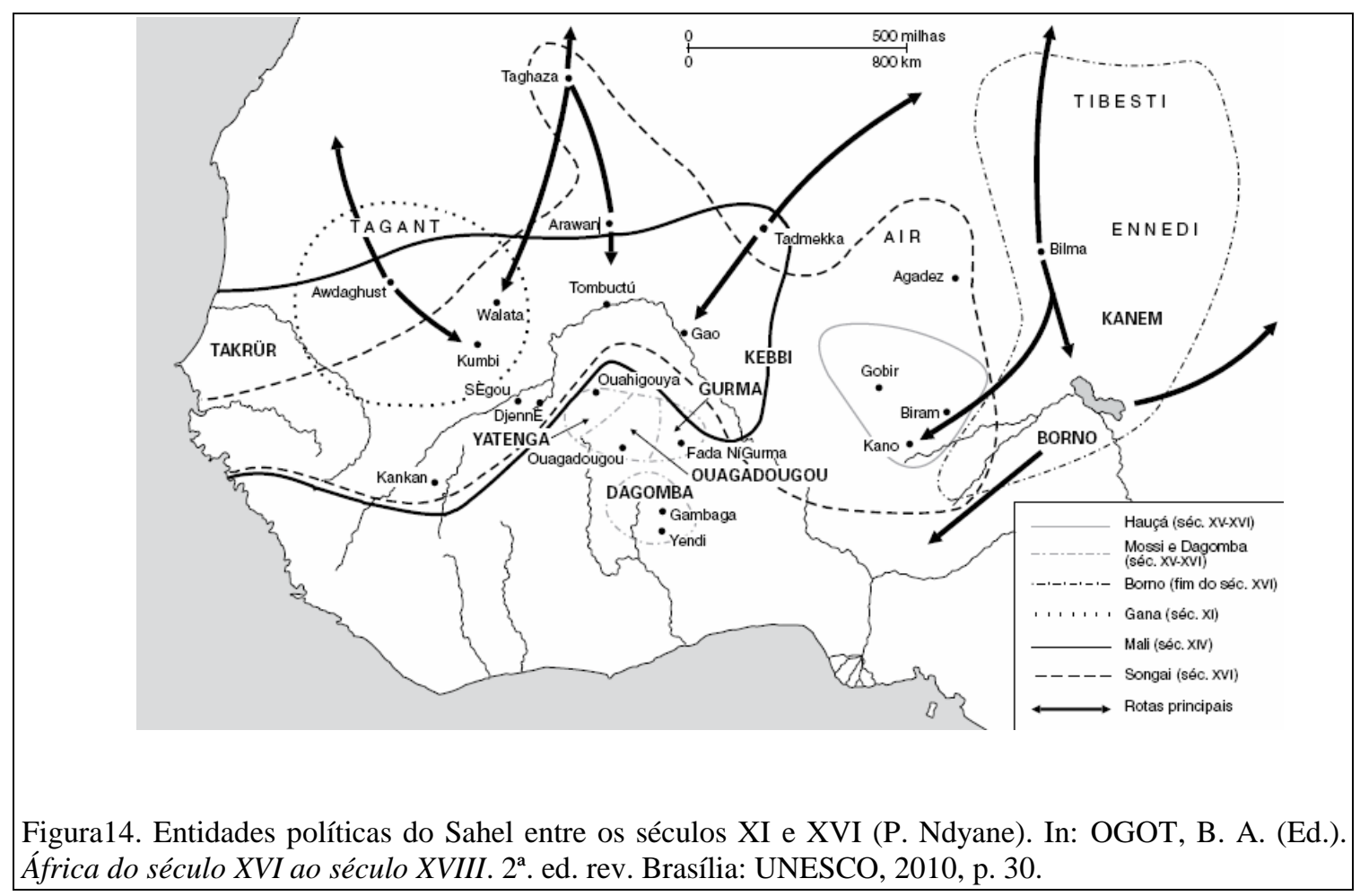


O principal argumento da abordagem regionalista na $H G A$, neste sentido, se refere à suposta estrutura e composição agrária das sociedades africanas no período histórico citado. Sem negar a importância crescente do comércio transaariano e do islamismo na África Ocidental, os artigos que aqui tipificamos como regionalistas buscam mostrar que o dinamismo destes elementos interferia em uma parcela pequena das populações africanas: os citadinos. Por isso, apesar do que diz a história da África tradicional desta região, dever-se-ia admitir que tais fatores pouco interfeririam na vida da maioria dos africanos, a qual teria continuado a se desenvolver fora deste círculo urbano. E isto, evidentemente, é algo a se considerar na realização da história da África.

$\mathrm{O}$ artigo mais generalista neste sentido é o de A. Ajayi (Introdução, Volume VI). Por isto o texto merece destaque embora enfoque um período histórico posterior: século XIX. Contrapondo-se a uma visão da história da África que se veria apenas como reflexo da expansão econômica europeia o autor levanta o papel central que a agricultura teria na vida material dos povos africanos até o século XIX. É necessária uma citação mais longa:

A agricultura empregava uma grande maioria da população (na África), ela provia as necessidades básicas, como a de comer, de se vestir e de se alojar, e seus produtos eram amplamente usados nas fabricações artesanais e industriais. Por isso é inconcebível que se possa atribuir-lhe menos importância do que ao comércio em geral e ao comércio exterior em particular. Convém destacar o fato de, no início do século XIX, a economia de todas as comunidades africanas fundavam-se na produção de alimentos por meio de uma ou mais atividades: cultivo do solo, criação de animais, pesca e caça. Todas as outras atividades - comércio, política, religião, produção artesanal e industrial, construção, exploração de minas - eram secundárias em relação a agricultura, e sem esta, não poderiam ter existido. Além de a agricultura ocupar, nesta época, um lugar central na vida econômica da imensa maioria dos africanos, os diversos sistemas de produção agrícola permitem, em grande medida, compreender a estrutura das relações sociais e políticas no seio das comunidades, as relações das comunidades entre si, e sua atitude frente ao comércio exterior. É, portanto, de se surpreender que os historiadores tenham concentrado toda sua atenção no comércio exterior, sem indagar sobre esses sistemas que fundamentavam as sociedades africanas (...).

Destacaremos mais uma vez a diversidade, do ponto de vista dos modos de produção agrícola, apresentada pelas diferentes áreas ecológicas da África, quer se trate dos sistemas de propriedade e de sucessão, das ferramentas básicas, dos tipos de culturas, do uso do solo, da divisão das tarefas entre homens e mulheres, ou ainda, da especialização das diferentes comunidades no que concerne a escolha das culturas, as técnicas agrícolas ou a criação de animais (Ajayi, 2010a, p. 12). 
É uma pena que a Introdução de Ajayi prometa mais do que a $H G A$ conceda, em verdade, em seus artigos específicos. E, por esta razão, mais uma vez ${ }^{60}$, vê-se desperdiçado o potencial explicativo que a abordagem regionalista poderia trazer para a história da África. Existem, todavia, exemplos importantes neste sentido, tratando do período histórico entre os séculos XIV e XVIII. Especialmente em relação à África Ocidental.

Este é o caso, por exemplo, do artigo de S. Cissoko: Os Songhai do século XII ao XVI (Volume IV), que dá alguns elementos interessantes neste sentido. O autor considera o Estado Songhai, no século XII, como uma sociedade gestada por uma longa evolução, com cerca de oito séculos. Nesta, diz o autor, existiria uma divisão de dois setores econômicos que foi se acentuando durante o período em estudo. O primeiro seria o mundo rural, tradicional e majoritário. O segundo seria o mundo urbano e comercial, em que o islamismo tornou-se dominante. Este, diz o autor, teria sido minoritário tendose difundido em cidades comerciais, como Gao e Tombuctu.

Diz Cissoko que cada um destes mundos - rural e urbano - possuiria suas hierarquias, culturas e formas de organização que lhes seriam próprias. O segundo dominaria o primeiro, mas sem direcionar-lhe a produção, visto que esta seria dirigida para o auto-consumo dos camponeses e das elites locais. A única exceção a esta regra seriam os tributos reais e as fazendas dos soberanos, que empregariam escravos. Todavia, afirma o autor, estas nunca teriam se tornado dominantes no mundo rural da sociedade Songhai (Cissoko, 2010, pp. 228-234).

Um argumento próximo ao de Cissoko permea o artigo de M. Adamu (Os Haussa e seus vizinhos do Sudão Central, Volume III ${ }^{61}$ ). Aí, o autor defende que os haussa seriam essencialmente um povo agricultor, antes do que comerciante, como costumeiramente são apresentados. Em suas palavras: “Apesar de ter-se a impressão de

\footnotetext{
${ }^{60}$ Ver nota 52. A história das formas de alimentação das populações africanas poderia ser um excelente objeto de estudo, para comprovar suas teses. Afinal, assim poder-se-ia mostrar que os elementos externos - comércio externo, islamismo, tráfico escravista, etc -, neste particular, pouco teriam afetado a história das populações africanas, até o século XIX. Tal estudo, ademais, poderia trazer um viés menos estatista para a abordagem regionalista, centrada no estudo das sociedades complexas e do Estado.

${ }^{61}$ Consta a seguinte nota de rodapé na $H G A$, sobre a autoria deste capítulo:

O Bureau decidiu revisar este capitulo, utilizando uma contribuição de Andre Salifou. A revisão de conjunto foi realizada por um subcomitê, designado pelo Comite Cientifico Internacional, composto pelos professores Jean Devisse, Ivan Hrbek e Yusuf Talib (Adamu, 2010, p. 299).
} 
que os Haussa se dedicavam sobretudo ao comércio, (eles) foram, na verdade, antes de mais nada, agricultores, sendo a agricultura o centro da vida econômica do país" (Adamu, 2010, p. 332). Os haussa teriam praticado muitas culturas, incluindo diversas variedades de milhete, sorgo, fonio e arroz. A cultura de plantas industriais, como o algodão e o indigo, teria sido particularmente importante no Estado de Kano (Adamu, 2010, p. 333) ${ }^{62}$.

Para Adamu, depois da agricultura, o artesanato e a produção metalúrgica seriam as atividades mais importantes para a economia haussa, "desde bem antes do século XIV". Esta característica é que, inclusive, teria possibilitado o florescimento do comércio haussa (Adamu, 2010, p. 333; Laya, 2010, p. 565). Diferentemente de Cissoko, entretanto, em relação aos songhai, Adamu acredita que entre os haussa existia um forte controle administrativo dos campos por parte dos soberanos e do seu corpo burocrático. Daí a grande quantidade de escravos nas grandes propriedades rurais. Especialmente a partir de fins do século XV. Por outro lado, assim como Cissoko, Adamu descreve o Islã no país Haussa como uma religião de elite, dissociada das populações rurais (Cissoko, 2010, p. 236; Adamu, 2010, p. 328).

Ainda tratando da África Ocidental, há outro artigo regionalista da $H G A$ que se deve destacar: A. Ryder (Do Rio Volta ao Camarões, Volume IV). Tratando do período entre os séculos XII e XV o autor estuda características originais da história dos povos da região florestal da África Ocidental. Sua tese é que elas explicariam a formação dos espaços urbanos e dos Estados nesta sub-região africana. Aí incluindo, entre outras, as sociedades Ioruba (em suas variantes), Ibo, Igbo-Ikwu e Ijaw.

Para Ryder, a urbanidade e a formação do Estado na região de seu estudo (florestas da África Ocidental) teria sido decorrente de um adensamento populacional, que teria ocorrido no local na segunda metade da presente Era. Tal fato seria derivado de três fatores interligados: a) o aperfeiçoamento das técnicas de metalurgia e emprego de ferro na região; b) a derrubada de florestas; c) o surgimento de um regime alimentar mais rico e diversificado. Um exemplo típico deste processo histórico teria ocorrido na aglomeração populacional dos Ibo, na floresta a Leste do Niger. Esta teria sido, não por coincidência, simultânea da cultura intensiva do inhame e da abundância de dendezeiros nesta região durante o período considerado. Nesta época, segundo o autor,

\footnotetext{
${ }^{62} \mathrm{O}$ mesmo argumento vê-se em D. Laya (Os Estados Haussa, Volume V). Este autor afirma que, ainda durante o período posterior ao estudado por Adamu (XII-XIV), entre os séculos XV-XVIII, as sociedades Haussa seriam essencialmente formadas por camponeses e pastores (Laya, 2010, p. 564).
} 
as derrubadas teriam chegado a provocar a devastação das florestas locais (Ryder, 2010, pp. 379-382).

Para o autor, portanto, os três fatores citados teriam sido essenciais para uma exploração mais intensiva do solo, assim como o surgimento de grandes aglomerações em aldeias. Tratar-se-ia de uma transformação por adaptação interna, em que os fatores externos seriam diminutos. Politicamente tal mudança teria duas características primordiais. Em primeiro lugar, o fato da liderança local perder seu caráter transitório. Secundariamente, o surgimento de instituições com um espírito comunitário (não mais familiar), como as instituições secretas e as classes de idade. Acredita o autor que, se o solo fosse fértil, uma vez estabilizada a aldeia podia crescer rapidamente formando uma cidade. O Estado seria, neste cenário, uma decorrência da necessidade de organização desta nova vida social. Sobretudo porque permitiria impor a dominação de uma aldeia principal ou de uma cidade sobre as demais (Ryder, 2010, p. 387).

Segundo Ryder, um exemplo típico desta evolução à urbanidade e ao Estado, sem qualquer influência exterior perceptível, poderia ser encontrado na transformação da aldeia autônoma dos Ijaw em comunidade com características ao Estado, no século $\mathrm{XV}$. Todavia, o autor acredita que este esquema interpretativo (originalmente trabalhado por R. Horton ${ }^{63}$ ), poderia ser também útil, grosso modo, para explicar o processo de evolução interna de outras cidades nesta região florestal no século XII. Em especial os estabelecimentos Ioruba: Ifé, Ijesha, Ekiti, Ondo, Owo, Ikare, Ilage, Ijebu e Benim. Tais Estados teriam tido dimensões modestas, sendo quase sempre formados por uma única cidade e as aldeias próximas. A grande exceção seria o reino de Oyo; embora, em verdade, seu caráter "imperial" só tenha se desenvolvido no começo do século XVII. O autor acredita que esse caso único poderia talvez ser explicado pela topografia - savana típica -, onde prosperou. Esta teria permitido uma facilidade de movimentos maior que na floresta, impondo o domínio da cavalaria e dos grandes contingentes de infantaria dos Oyo, por distâncias maiores (Ryder, 2010, pp. 387-395).

Para o autor, uma vez estabelecido o Estado, ter-se-ia acelerado o ritmo da interação cultural entre as populações, favorecendo a difusão das instituições, práticas e objetos cerimoniais, cultos religiosos e, provavelmente, tecnologia. Além disto, as relações econômicas também teriam adquirido maior intensidade e complexidade. Por exempo, a construção do palácio do soberano, com suas necessidades de suprimento e

\footnotetext{
${ }^{63}$ HORTON, R. Stateless societies in the history of West Africa. In: AJAYI, J. F. A. \& CROWDER, M., eds. History of West Africa. Londres, Longman. v. 1, 1971, pp. 78-119
} 
serviços especializados, teria sido um fator determinante dessa evolução. Além disso, os Estados estariam melhor equipados para organizar o comércio - regional e exterior - , suprir mercados, organizar a coleta e transporte de produtos e garantir a segurança dos comerciantes que viajavam para longe (Ryder, 2010, p. 413). Estas seriam características marcantes destas sociedades desde então. Sua origem, portanto, seria interna e local. Por consequência, não relacionadas a fatores externos à África comércio exterior, migrações etc - ou mesmo de outras regiões e povos da África Ocidental, como Gana, Mali, Songhai etc. Alguns dos povos da floresta citados estão na figura abaixo:

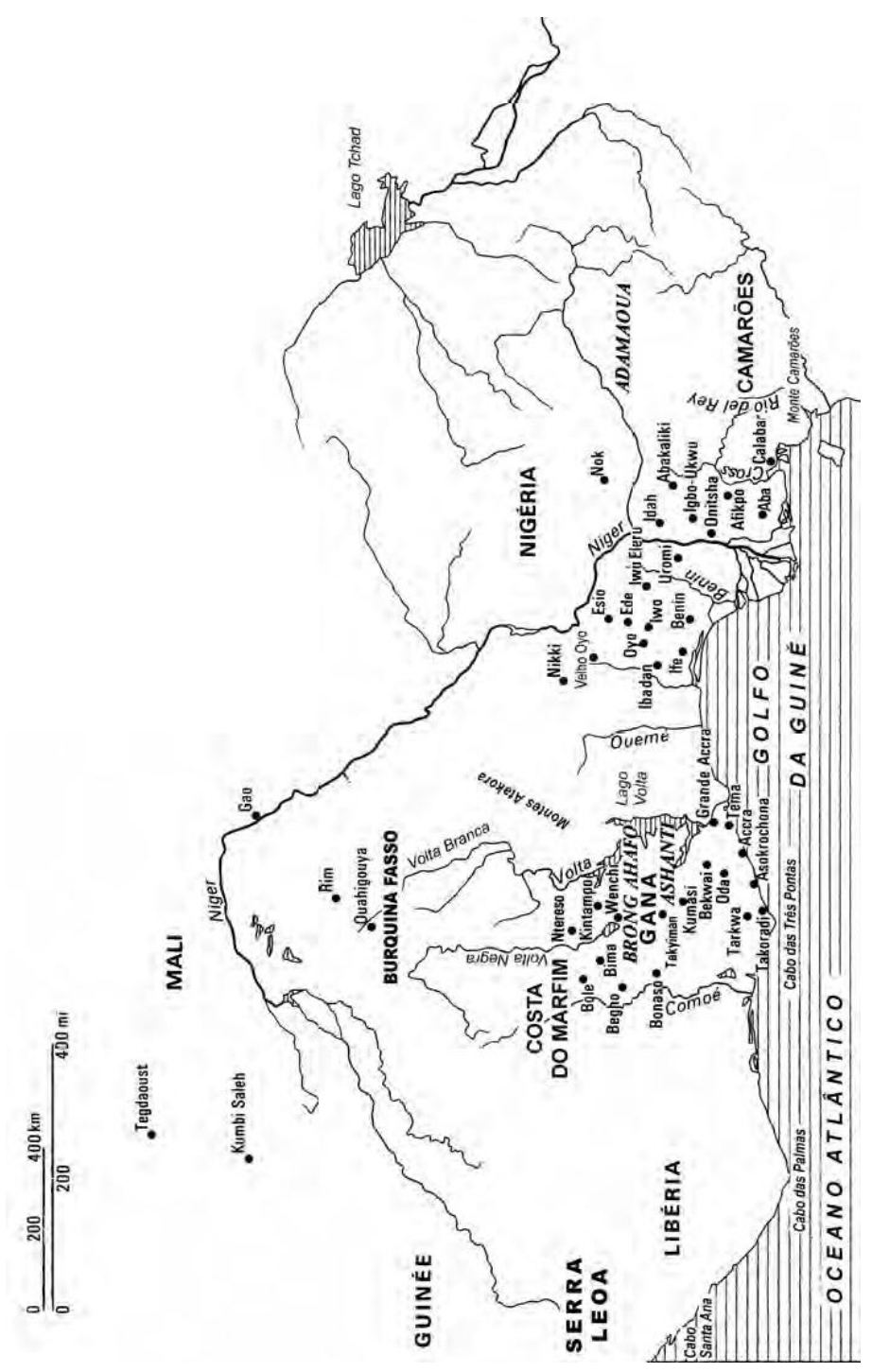

Figura 15. Algumas cidades e sítios mencionados no texto (B. W. Andah). In: FASI, M. El. (Ed.). África do século VII ao século XI. 2a . ed. rev. Brasília: UNESCO, 2010, p. 570. 
$\mathrm{O}$ artigo de Ryder traz uma tentativa original de complementar o regionalismo típico aqui tratado. O elemento novo aí citado é a derrubada das florestas. Este é um tema importante porque além de ser algo empiricamente analisável traz um elemento que liga, na mesma narrativa, as três pontas comuns da abordagem regionalista: a) desenvolvimento tecnológico; b) produção agrícola; c) processo de sedentarização; da aldeia para a cidade e daí para o Estado. No entanto, dois problemas surgem para sua generalização. Em primeiro lugar, a utilização deste argumento é limitada às áreas de zona florestal. Secundariamente, ele tende a naturalizar uma transformação política que não é inata nem necessária à história: das aldeias para à cidade e daí para o Estado.

Este último ponto leva a considerar o problema do evolucionismo na história da África, da $H G A$. Não resta dúvida que a maioria dos artigos da $H G A$ possuem um caráter evolucionista. Este tema não é o objeto de estudo desta tese. Mas a exposição que aqui se realiza mostra, indiretamente, este fato. Isto porque, tanto para os difusionistas intra-africanos, quanto para os regionalistas, trata-se de construir uma história da África voltada para o estudo das sociedades complexas e do Estado, ou seja, das civilizações, sociedades urbanas, instituições.

É certo que, ao fazer esta história, os autores davam consequência a uma das premissas primordiais do projeto da $H G A$, destacada na Apresentação à obra ${ }^{64}$. No entanto, vale destacar que tal percepção evolucionista não é algo intrínseco ou necessário à escrita da história desde uma perspectiva africana, conforme aqui definida, em suas variadas abordagens. Afinal, realizar uma história da África enfatizando fatores internos a própria África não implica reproduzir um viés evolucionista dessa história.

Um artigo que exemplifica como a perspectiva africana não é necessariamente evolucionista, nem na $H G A$, é o de D. Denoon (A África Austral, Volume V) ${ }^{65}$. Neste artigo o autor defende uma abordagem regionalista não evolucionista para analisar os diferentes modos de vida das populações africanas na África Austral. Vale citar o próprio autor:

\footnotetext{
${ }^{64}$ Ponto (3) da referida Apresentação:
}

A História Geral da África consiste, antes de tudo, em uma história das ideias e das civilizações, das sociedades e das instituições. Ela fundamenta-se sobre uma grande diversidade de fontes, aqui compreendidas a tradição oral e a expressão artística (Ogot, 2010a, p. XXVIII).

\footnotetext{
${ }^{65}$ Outro exemplo é o artigo de M. Izard \& J. Ki-Zerbo (Do Níger ao Volta, Volume V, p. 419 e seguintes).
} 
Se conseguirmos nos desvencilhar da ideia de um processo histórico irresistível, torna-se lícito descobrir que as relações sociais na África Austral apresentavam, no século XVI, características muito interessantes. É assim que as diferenças ecológicas permitiam as comunidades especializarem-se em certa medida. Estas sociedades especializadas influenciavam-se mutuamente, mas tais interações não prejudicavam a permanência dos meios de subsistência de cada uma. Os caçadores não "evoluíam" para tornarem-se criadores nem os criadores para transformarem-se em cultivadores; havia antes coexistência, apesar das hostilidades que às vezes marcavam suas interações. Merecem essas interações um momento de atenção, nem que seja porque seu estudo pode nos preparar para o estudo das relações que se estabeleceram em seguida (Denoon, 2010, p. 811).

Ao citar os caçadores e os criadores, o autor se refere, grosso modo, respectivamente, aos chamados San e Khoi, populações autóctones da África Austral. O argumento do autor é que na medida em que tais populações não encontraram na região em que se estabeleceram - a metade ocidental da África Austral (atuais Namíbia e Botswana) -, condições climáticas e ecológicas adequadas à produção agrícola, elas tiveram que se especializar em outras atividades produtivas para garantir a sua sobrevivência. Tal fato, diz Denoon, não implica um "atraso" destas populações em relação a outras. Pelo contrário, revela uma capacidade inventiva própria que lhes possibilitou adequar o meio ambiente, na medida do possível, às suas necessidades (Denoon, 2010, p. 812). Para comprovar esta argumentação o autor analisa, pormenorizadamente, o aparato e o conhecimento técnico que teria sido utilizado por cada um destes grupos para torná-los independentes de outras sociedades e assegurar uma relação equitativa entre densidade populacional e recursos ecológicos.

Contudo, não se trata aí de um quadro invariável. Por exemplo, Denoon afirma que entre os séculos XV e XVIII, período estudado em seu artigo, também os Khoi teriam sido caçadores e pescadores, assim como os San teriam domesticado ovinos e caprinos. Do mesmo modo outros povos africanos tidos como agricultores, como os Xhosa e os Shoto, por exemplo, podiam dedicar-se à caça e coleta quando a situação ecológica não lhes era favorável. No entanto, o argumento central do autor é que tais mudanças conjunturais, assim como as trocas decorrentes da relação entre tais povos, não impeliam as populações locais a adotarem o modo de vida de outros povos, que já estavam habituados e especializados ao seu próprio meio ambiente e social (Denoon, 2010, p. 819). Tal situação só se teria alterado em fins do século XVIII com a 
instauração do comércio de rebanho imposto pela Companhia das Indias Holandesas (Denoon, 2010, p. 830).

Além de não ser evolucionista o artigo de Denoon tem outra característica que merece destaque: trata-se de um raro artigo regionalista da $H G A$ sobre a África SubEquatorial (ou África Austral). O leitor deve ter percebido que a investigação até aqui realizada, tratando da abordagem regionalista, pode dar a entender que ela se circunscreveria à África Sob-equatorial. Afinal, as áreas mais citadas para exemplificar tal abordagem, foram o Vale do Nilo, na Antiguidade, e a África Ocidental, desde o início da presente Era. Foram poucos os textos regionalistas citados, que tratam da África Sub-Equatorial. Pode-se enumerá-los: a) V. Noten (Volume I: Pré-história da África Central, parte II; em colaboração com P. Maret, J. Moyersons, K. Muya, E. Roche); b) V. Noten (Volume II: A África Central; em colaboração com D. Cohen e P. Maret); c) Masao \& Mutoro (A costa da África Oriental e as ilhas Comores, Volume III); d) a curta seção final escrita por S. Lwanga-Lunyiigo, no artigo trazido em coautoria com J. Vansina (Os povos falantes de banto e sua expansão, Volume III).

Este desproporção é reflexo da própria escrita da história da $H G A$. A causa fundamental para este fato parece ser que a história tradicional da África Sub-Equatorial à época (até hoje, em verdade), estava alicerçada na investigação da genealogia e das consequências que os movimentos populacionais teriam trazido para esta região da África, provindos da África Oriental e Ocidental. Enfim, como visto no capítulo segundo, tais movimentos populacionais - dos banto, cuxitas e nilotas - teriam trazido os elementos neolíticos às populações africanas da África Sub-Equatorial. Em especial, com a difusão da metalurgia do ferro e o início da produção agrícola. Os textos citados de Noten e Lwanga-Lunyiigo visam problematizar esta narrativa, mas são exceções à regra.

O fato é que o domínio desta narrativa difusionista intra-africana em relação a África Sub-Equatorial, tornou diminuto o espaço da abordagem regionalista sobre esta vasta região da África, na $H G A$. Por outro lado, por esta mesma razão, a quantidade de artigos regionalistas aumenta quando se trata de estudar a África Sub-Equatorial após o século XII. Isto ocorre porque a partir deste momento histórico já haviam se findado os supostos movimentos populacionais mais expressivos advindos da África SobEquatorial. Algo que torna a abordagem regionalista da África Sub-Equatorial, portanto, mais verossímil. Um bom exemplo deste regionalismo "pós-migratório" é o 
artigo de W. R. Ochieng ( $O$ interior da África do Leste: os povos do Quênia e da Tanzânia, 1500-1800, Volume V).

Neste artigo Ochieng defende que a história dos vários povos do interior da África Oriental, entre os séculos XV e XVIII, possuiria um caráter específico e autonômo, derivado do relativo isolamento das populações locais em relação a fatores supra-regionais ou externos à África. Trata-se, pois, de uma história regional da África Austral, não mais marcada pelo fenômeno migratório. Entre estes povos locais o autor ressalta os seguintes: a) na região central: Masai, os Chagga, os Pare, os Shambaa, os Gogo e os Hehe; b) na costa leste, os Kikuyu, os Kamba, os Miji-Kenda, os Zigua e os Zaramo; c) no noroeste, os Abaluyia (Luyia), os Kalenjin, os Luo, os Abagusii (Gusii) e os Abakuria (Kuria); d) no sudoeste, as comunidades tanzanianas como os Sukuma, os Iramba, os Nyamwezi, os Zinza e os Kimbu (Ochieng, 2010, p. 977).

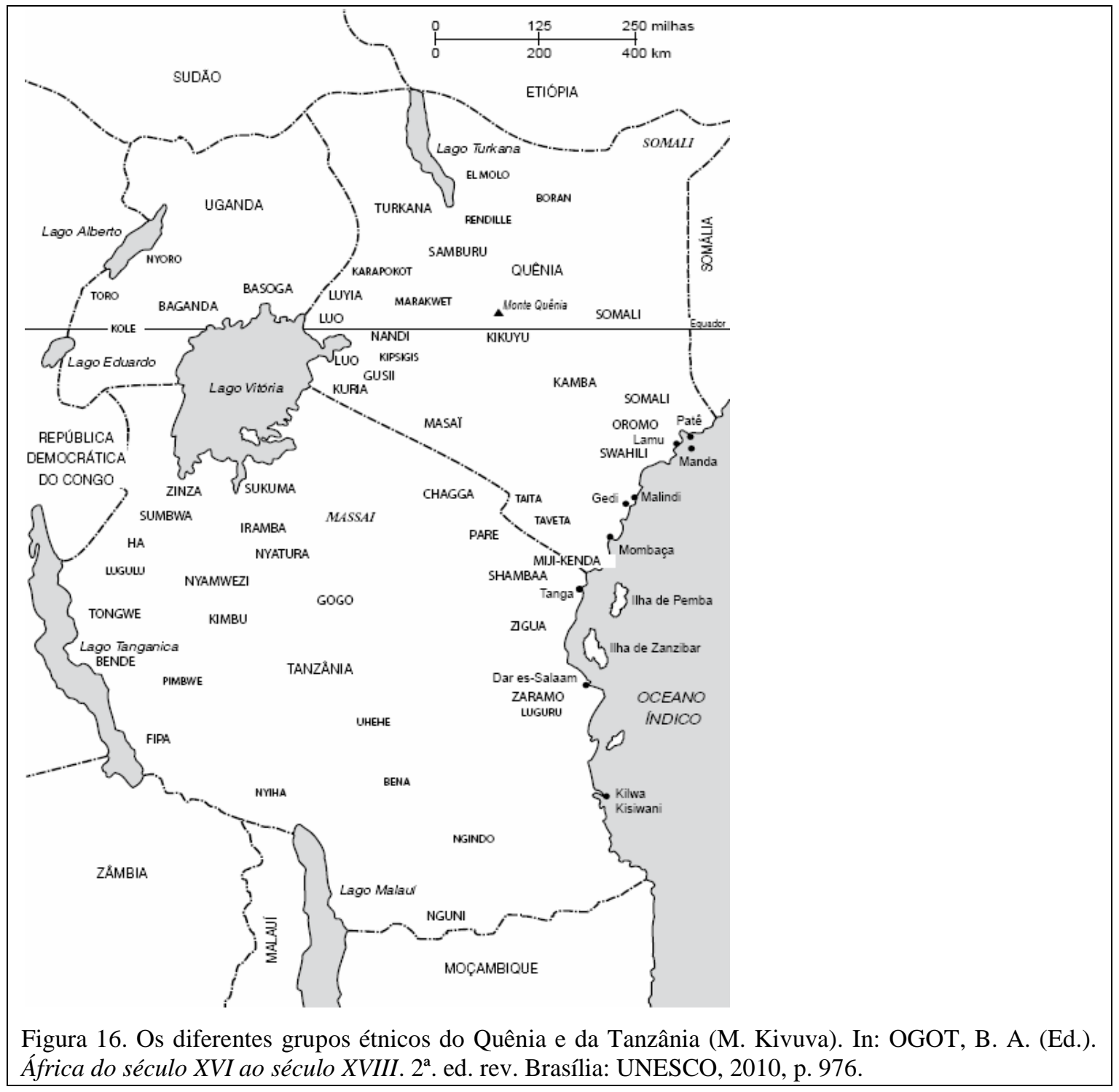


Esta história autônoma, regionalista, é analisada pelo autor nos mais variados aspectos, entre os séculos XV e XVIII: ecológicos, econômicos, sociais, políticos e culturais.

Ecologicamente, o período citado seria o cume de um processo secular em que as comunidades amadureciam sua adequação ao meio, observando as suas particularidades e se esforçando para pôr em prática técnicas que lhes permitissem utilizá-lo de modo racional. Aplicariam, por exemplo, métodos evoluídos como a cultura em terraços, a rotatividade de culturas, os adubos verdes, a cultura mista e a drenagem dos pântanos. Destacar-se-ai aí também a utilização intensa dos instrumentos de ferro: machados, enxadas, panga e venábulos (Ochieng, 2010, p. 981).

Economicamente, entre 1500 e 1800, a produção de víveres teria sido um fator primordial para a sobrevivência e a expansão das sociedades locais, uma vez que ela teria permitido um crescimento regular da população. No entanto, a pesca e a caça teriam continuado a ter importância local. À medida que as explorações agrícolas extensivas e as pastagens cobriam a maior parte da África do Leste e que a produção permitia satisfazer as necessidades essenciais, ter-se-ia passado a conservar e estocar alimentos. A partir deste momento, poder-se-ia empregar o tempo livre para outros fins além da procura dos meios de subsistência. Este teria sido na região o início do processo de especialização, desobrigando determinados indivíduos da tarefa de produzir alimentos para que se consagrassem a outros objetivos tais como a produção de mercadorias, a condução da guerra, o serviço do Estado, a arte, a religião, a medicina, a filosofia e o progresso técnico (Ochieng, 2010, p. 985). Neste contexto, o comércio teria sido estimulado pelos contatos entre regiões ecológicas distintas e culturas, ao mesmo tempo heterogêneas e complementares (Ochieng, 2010, p. 986).

Politicamente tratar-se-ia de um período de oscilação entre a superioridade numérica tornada possível pela agricultura e a organização político-militar disciplinada que a vida pastoril exigiria. $\mathrm{O}$ equilíbrio teria balançado ora em favor de um, ora em favor de outro destes modos de vida, segundo as flutuações da organização e da coesão sociais e em função do progresso técnico. Haveria, no princípio do século XVIII, dois tipos de formações sócio-políticas nesta zona: as sociedades organizadas em nível descentralizado (Kikuyu, Miji-Kenda, Kambae, Masai) e as centralizadas (Shambaa, Pare, Nyamwezi e Wanga) (Ochieng, 2010, pp. 992-993). Estas últimas delineariam uma evolução orientada para a generalização de um modo de produção tributário. Em outras palavras, sociedades em que se teria uma tendência deliberada a realizar uma 
integração social e política, no seio de comunidades econômicas e políticas cada vez mais extensas. Nestas, os soberanos tiravam o tributo para sustentar sua família e seu séquito (Ochieng, 2010, p. 977). A formação das hierarquias políticas, portanto, teria origem local. Sobre este ponto vale citar o autor quando este critica o viés difusionista intra-africano que teria marcado a história política da região:

A semelhança surpreendente que a organização destas chefias e as insígnias dos chefes (nyamwezi) apresentavam conduziu, em certa época, historiadores como R. Oliver e J.D. Fage (Breve história da África, 1962) a lançar a hipótese de uma origem comum, situada por eles em Uganda, em Ruanda, no Burundi e, voltando ainda mais no tempo, no vale do Nilo. Contudo, especialistas da história política da Tanzânia refutaram essas teorias difusionistas que, em alguns casos, são marcas de racismo. I. N. Kimambo, particularmente, sustentou que a explicação das semelhanças entre entidades políticas da África, seja em escala regional, seja em escala continental, deveria ser procurada entre os povos de agricultores e que as diferenças de grandeza entre estas entidades se explicavam pela adaptação ao meio e a certos fatores externos.

Andrew Roberts afirma, por exemplo, que as numerosas chefias nyamwezi provavelmente não eram oriundas de um único processo de migração ou difusão, mas do meio onde viviam os nyamwezi. `Muito cedo, mas não sabemos com exatidão em que época, certos homens foram respeitados por seus poderes mágicos, porque eles sabiam fazer cair a chuva, desmatar as florestas ou arbitrar os conflitos'. É ao redor destes homens que nasceram as chefias nyamwezi (Ochieng, 2010, p. 995).

Por fim, culturalmente, o período tratado se teria caracterizado pela tendência à constituição de grupos linguísticos e étnicos cada vez mais importantes. Neste sentido, diz o autor, o mapeamento lingüístico da África Oriental estaria, em 1800, em vias de tomaro aspecto que ele teria hoje em dia, embora as migrações internas continuassem a se produzir, rumo a regiões menos povoadas ou desabitadas (Ochieng, 2010, p. 990).

Em suma, para Ochieng, falar da história da África neste período entre 15001800 e nesta região específica (interior da África Oriental) implicaria entender como os povos citados (Luo, Kykyup, Zinza etc) se teriam desenvolvido em isolamento relativo. Em suas palavras:

Seus habitantes (do interior da África Oriental) tinham prosseguido em um ritmo regular, porém lento, o desenvolvimento de sua própria civilização. Esta civilização da idade do ferro tinha numerosos êxitos a seu favor. Tinha progredido muito e tinha inventado muitas coisas nas artes da vida comunitária, na cultura de novos produtos agrícolas, 
na aquisição e difusão de técnicas de trabalho do metal, no desenvolvimento das trocas comerciais e, mais importante ainda, nos métodos de autogoverno e nas maneiras de manter a paz (Ochieng, 2010, p. 1000).

Este artigo de Ochieng exemplifica bem o que se pretende aqui tipificar como abordagem regionalista da perspectiva africana. Ele trata de uma multiplicidade de fatores envolvidos na explicação histórica - ecológicos, econômicos, políticos, culturais, sociais - de forma holística, como uma totalidade complementar e interrelacionada. Mas, como é próprio da abordagem regionalista, trata estes elementos na longa duração, como parte de uma dinâmica ecológica maior: a adaptabilidade ao meio ambiente.

Todavia, deve-se destacar um fato importante. Até este momento os artigos tidos por regionalistas puderam se utilizar do argumento do "isolamento" (sempre relativo) das sociedades que estudavam para legitimar tal abordagem da história da África. O artigo de Ochieng é exemplar também neste caso. É verdade que, quanto mais isolada é uma sociedade, mas fácil é construir uma história internalista e regionalista dela. Por outro lado, conforme o tempo histórico se aproxima do presente, maior a dificuldade de se escrever esta mesma história, visto que as sociedades estão, de fato, cada vez mais inter-relacionadas. Este é um fato objetivo que desafia o historiador que busca escrever uma história internalista da África (ou de qualquer outro lugar). Mas ele afeta especialmente o regionalista, que busca no particular os elementos essenciais da dinâmica histórica.

Por esta razão fundamental o regionalismo da $H G A$ está praticamente ausente dos objetos de estudo, que dificilmente podem ser "isolados" do seu contexto supraregional. Este é o caso, por exemplo, de certas regiões litorâneas da África, em que o tráfico escravista tornou-se um fato essencial e incontornável da história local, como na África Centro-Ocidental durante os séculos XVII e XVIII ${ }^{66}$. Em relação aos séculos XIX e XX isto é ainda mais evidente.

A pergunta que se impõe, portanto, é se a abordagem regionalista limitar-se-ia à história das sociedades relativamente "isoladas".

A partir da própria $H G A$, pode-se concluir que não. Evidentemente esta situação de "isolamento" é a mais cômoda para tal abordagem. No entanto, alguns artigos minoritários desafiam esta restrição. No período histórico aqui tratado, entre os séculos

\footnotetext{
${ }^{66}$ Sobre este tema particular, ver Capítulo 2.
} 
XII e XIX, pode-se observar tal fato, por exemplo, nos artigos de H. Bhila (A região ao Sul do Zambeze, Volume V), D. Cohen (Povos e Estados da região dos Grandes Lagos, Volume VI) e L. Ngcongco (O Mfecane e a emergência de novos Estados Africanos, Volume VI). São exemplos que devem ser destacados.

No primeiro artigo citado, Bhila (A região ao Sul do Zambeze, Volume V) apresenta a história dos povos e das sociedades da região do Sul do Zambeze, na África Austral, durante os séculos XV e XVIII. Mais especificamente, traz uma investigação das bases históricas sobre as quais se fundaram as sociedades Shona, em particular os Impérios de Mutapa e Rozwi, no período histórico referido.

Para Bhila o fator primordial desta história seria um fator rigorosamente local: a base ecológica de tais sociedades. Isto porque, segundo ele, as sociedades Shona teriam se organizado nos planaltos do Zimbabwe, o mesmo espaço ecológico em que teria se formado, anteriormente, o Grande Zimbabwe (1.200 -1.450 d C.). Para o autor, este fato não seria uma coencidência. Pelo contrário, ele comprovaria a importância deste meio, em especial por suas terras férteis, para a produção agrícola e o pastoreio ali existentes. Afinal, tais elementos seriam a base das sociedades Shona (seja Mutapa ou Rozwi), assim como teria sido a do Grande Zimbabwe. Para ambas, o comércio internacional de ouro e de cobre teria sido apenas complementar em relação a esta economia localregional (Bhila, 2010, p. 756; p. 792).

Este posicionamento do autor é polêmico durante o período histórico tratado. Isso porque, a partir de 1540, a pressão dos portugueses sobre Mutapa e outros Reinos da região do Zambeze (como Uteve e Manica), fez crescer as redes comerciais na África Central, passando a incluir os escravos e o marfim entre os itens de maior procura. Esta pressão aumentou ainda mais após a segunda metade do século XVII com a formação dos prazos (terras da Coroa) na região, controlados pelos portugueses - negociantes, pioneiros, mercadores, religiosos, funcionários ${ }^{67}$.

\footnotetext{
${ }^{67}$ Explicação dos prazos, conforme o autor:
}

O regime do prazo era uma síntese de dois sistemas socioeconômicos. O primeiro era aquele dos shona, cuja sociedade dividia-se em uma oligarquia dirigente e camponeses produtores. O segundo, que se sobrepunha ao precedente, era o dos prazeros, reinando como classe dominante sobre os chikunda (exércitos de escravos). Em outras palavras, os prazeros perpetuaram o sistema sociopolítico encontrado por eles ao chegarem a região do Zambeze. O chefe africano continuava a exercer as funções tradicionais, porém, "sem deter, a partir de então, a autoridade absoluta", o prazero atribuindo a si próprio o título de suserano. Nesse sentido, sua relação aparentava-se aquela existente entre o chefe e o subchefe no Império Mutapa (Bhila, 2010, p. 767). 
Bhila não nega a importância deste fenômeno histórico. Mas acredita que o "fator português" era ainda controlável pelos Shona, desde que estes se organizassem para tal. Em suma, formassem Estados poderosos, fundados no poder e na produção local. Neste sentido, o autor defende que a ascensão dos portugueses na região, no século XVI, só teria sido possível com a decadência do Império Mutapa. E, no mesmo sentido, entende que a razão primordial da decadência dos prazos na região tenha sido a consolidação do Império Rozwi, no início do século XVIII (Bhila, 2010, p. 774).

Os rozwi, segundo autor, seriam parte do povo Kalanaga, que seriam integrantes do Império Mutapa até se formarem com uma identidade própria, no século XVII. Para preservarem o império os rozwi teriam empregado os mesmos métodos que os mutapa: a atribuição de terras, o tributo, a religião e o treinamento de um exército eficaz. Tal exército ficou conhecido por sua lendária invencibilidade, que se estabeleceu após a vitória sobre os portugueses, no fim do século XVII (Bhila, 2010, p. 777).

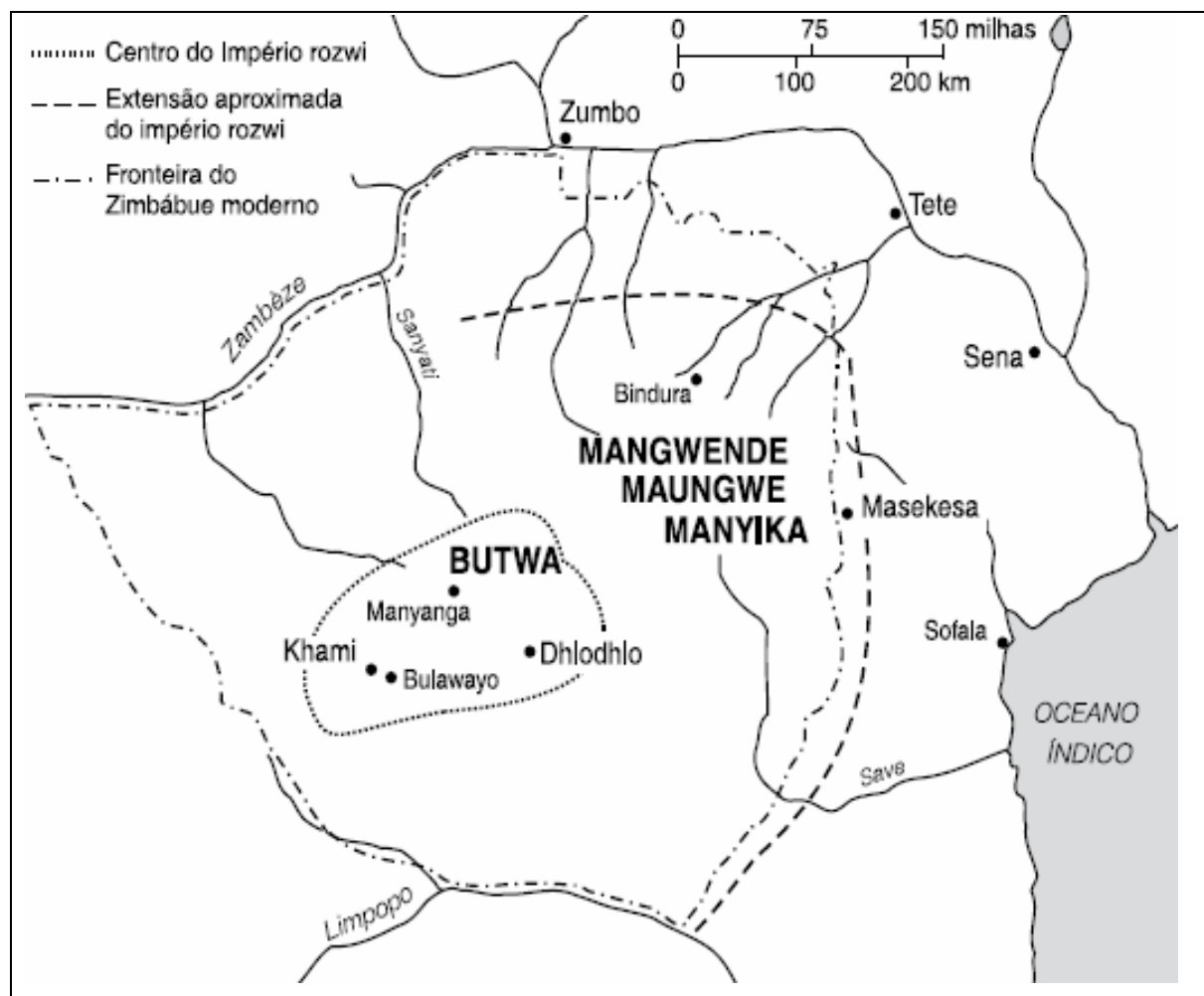

Figura 17. O Império Rozwi (D. N. Beach). In: OGOT, B. A. (Ed.). África do século XVI ao século XVIII. $2^{\mathrm{a}}$. ed. rev. Brasília: UNESCO, 2010, p. 775.

Todavia, independente de ser Mutapa ou Rozwi, diz o autor, os principais setores de atividade nas sociedades shona eram a agricultura, a criação de animais domésticos, a colheita, a pesca e o trabalho dos metais. Secundariamente havia o 
comércio longínquo e inter-regional. Esta agricultura dependenderia de três cereais principais: o milhete vermelho, o milhete perolado e xerófilo, além de diversas variedades de sorgo. Esta base teria sido por vezes complementada, no período de 15001800, com novas culturas importadas da Europa e da Ásia. Sobretudo o arroz, o milho e os inhames. Tais itens, entretanto, segundo o autor, não teriam se incorporado, neste período, à base alimentar dos shona (Bhila, 2010, p. 780).

Para Bhila, a importância desta economia interna na história dos shona teria sido negligenciada, entre outros motivos, por uma leitura a-crítica de certas fontes portuguesas, pelos historiadores. Afinal, daí ter-se-ia legitimado uma visão histórica da agricultura destes como "primitiva" e "estática", em que os shona (e outros povos africanos) seriam vítimas passivas da carestia e dos desastres naturais. Entretanto, diz o autor, tal interpetação seria contrária aos fatos. Para ele, pelo contrário, os estudo atuais mostrariam que a agricultura shona seria essencialmente dinâmica, contando com estratégias de curto e longo prazo, como a estocagem de alimentos, escambo e alternância de produtos (Bhila, 2010, p. 786).

Em suma, para Bhila, os dados econômicos referentes à sociedade shona Mutapa e Rozwi -, portanto, mostrariam que a vida desta população africana até fins do século XIX ter-se-ia mantido, essencialmente, com os mesmos elementos de sua formação no século XV (Mutapa). Especialmente em relação ao regime alimentar destes, que teria passado por um processo de evolução basicamente interno durante o periodo referido.

Esta visão regionalista da história da África recente é reforçada no segundo estudo citado, de D. Cohen (Povos e Estados da região dos Grandes Lagos, Volume VI). Todavia, o faz com outro viés: focando a vida política dos Estados dos Grandes Lagos. Isto ocorre porque, neste artigo, o autor analisa o processo de centralização do poder político na região dos Grandes Lagos no século XIX com um fenômeno interno local, supostamente independente da interferência estrangeira (inglesa) na região.

Para isto o autor inicia seu artigo historiando como os Grandes Lagos seria uma área antiga de ocupação urbana, bem irrigada e densamente povoada. Nesta região, desde o século $\mathrm{XV}^{68}$, ter-se-iam ali estruturados Estados fortes, com uma cultura

\footnotetext{
${ }^{68}$ Quanto a datação ver: Bethwell Ogot. A região dos Grandes Lagos. Vol. IV, p. 559. Em relação a história da região, entre 1500 e 1880, ver: J. B. Webster, B. A. Ogot \& J. P. Chretien. A região dos Grandes Lagos, de 1500 a 1800 . Volume V.
} 
política, princípios estruturais e ideologias próprias, determinadas por características regionais, com “castas”, classes e diversos arranjos pluriétnicos (Cohen, 2010, p. 320).

Esta ordem política teria evoluído consideravelmente durante o século XIX, com o surgimento de duas tendências principais. A primeira delas teria sido o fortalecimento da coesão e do poder de determinados Estados por meio do aumento da mão de obra e do comércio, do desenvolvimento de instituições burocráticas e da eliminação dos fatores de divisão. Além disto, haveria a disputa pelo controle das influências e das forças novas que penetravam na região. A segunda tendência teria sido a ascensão decisiva de quatro Estados na região dos Grandes Lagos: Buganda, Ruanda, Burundi e Bunyoro. Para o autor, essas duas tendências estavam estreitamente ligadas. No século XIX a prosperidade desses quatro grandes reinos basear-se-ia no mesmo tipo de reorganização da administração, no sentido de uma maior centralização: o fim das velhas querelas intestinas por meio da eliminação da oposição e a organização de campanhas de arrecadação de tributos e de expansão que solaparam os conflitos internos; a ampliação do reino por meio da conquista de novas regiões; a apropriação e incorporação de determinados setores da produção e do comércio da região, e, finalmente, a integração das forças e elementos novos que ali penetravam (Cohen, 2010, p. 321).

Diz Cohen que no século XIX a principal preocupação destes Estados seria ao mesmo tempo a produção e as trocas, qualquer que fosse o palco desse processo de acumulação, no contexto do antigo feudo ou além das fronteiras administrativas reais do Estado. Existiam também "excedentes estratégicos" para garantir a segurança alimentar. A história política da região no século XIX seria marcada pelas disputas entre estes Estados, assim como pelas resistências populares ao poderio e a tributação destes (Cohen, 2010, pp. 324-327).

Na medida em que tais Estados viviam basicamente da produção agrícola e do controle do comércio regional, o autor defende que não se deveria exagerar a importância do comércio internacional na região dos Grandes Lagos até a segunda metade do século XIX. Afinal, diz o próprio, teria sido apenas a partir desta época que este comércio teria passado a ter um papel central na região ${ }^{69}$.

\footnotetext{
${ }^{69}$ Para o autor, isto teria ocorrido por dois fatores primordiais. Primeiramente, pela difusão de novos gostos e imperativos de consumo emergentes entre as camadas inferiores da nobreza local. Isto teria facilitado a influência europeia na vida não apenas do maior dos Reinos, Buganda, mas em quase todas as partes dessa vasta região. Secundariamente, pela chegada das armas de fogo, que asseguraram a
} 


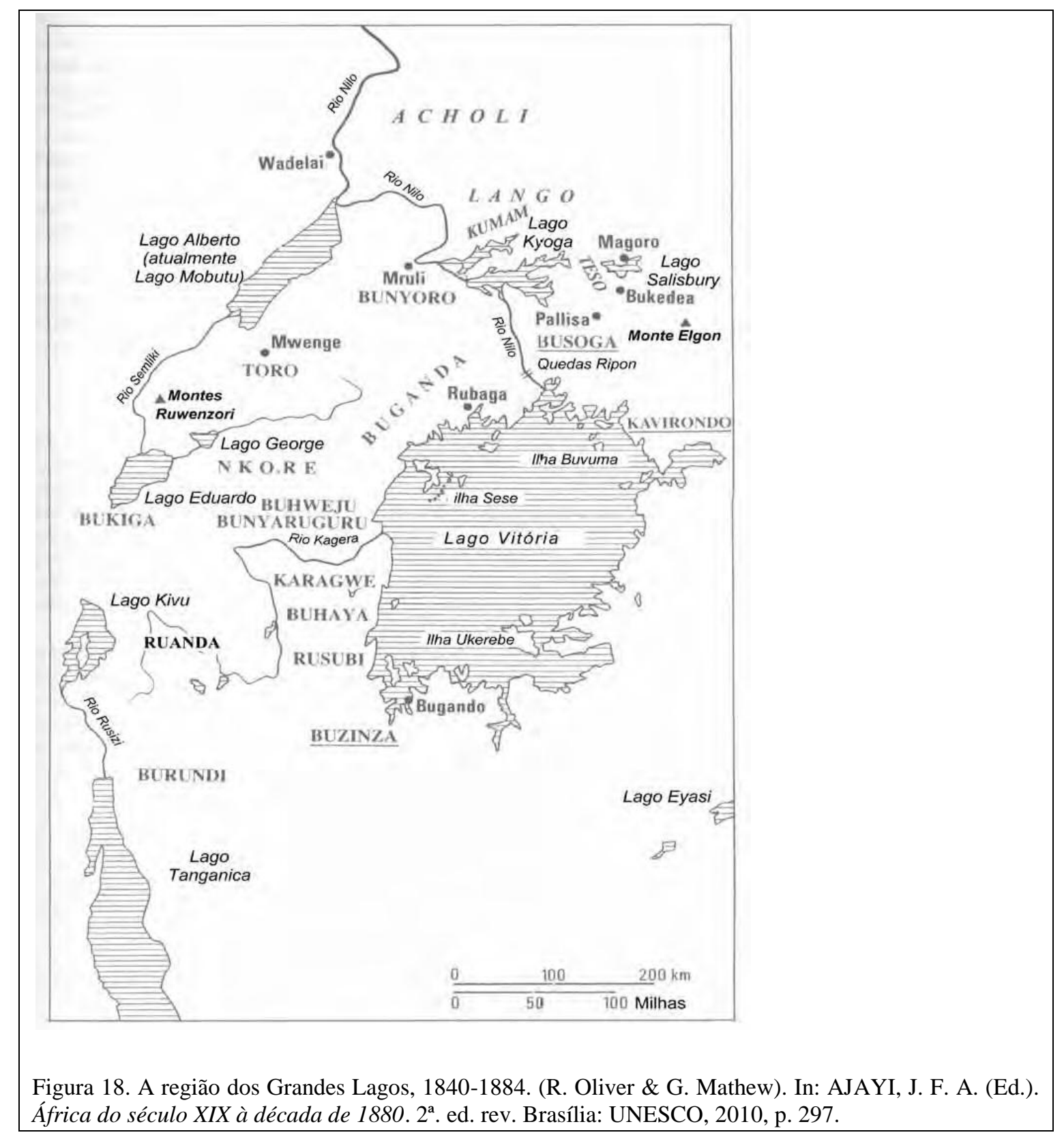

Enfim, por razões diferentes, tanto para Bhila quanto para Cohen, as regiões africanas estudadas por eles (respectivamente, Sul do Zambeze e Grandes Lagos) até fins do século XIX, mostrariam que os fatores internos à própria África seriam os elementos dominantes da realidade histórico-social à época.

dominação dos Estados mais poderosos sobre as áreas vassalas. Estas, como em todo o resto da África, teriam aberto o caminho para uma concentração do poder político-militar nas mãos de uma parcela mais limitada da população. Por isto, as desigualdades, particularmente flagrantes nas incursões para capturar escravos, teriam se acentuado na região dos Grandes Lagos, durante as últimas décadas do século (Cohen, 2010, p. 339). 
$\mathrm{O}$ artigo de L. Ngcongco (O Mfecane e a emergência de novos Estados Africanos, Volume VI) completa esta seção dos artigos específicos, que trazem concretude à abordagem regionalista na $H G A$. Neste ensaio, o autor defende que a origem dos revolucionários movimentos populacionais na África Meridional durante o século XIX, denominados de Mfecane ${ }^{70}$, estaria na carência de terras disponíveis nos territórios Nguni, na África Meridional - mais especificamente, nas proximidades da atual cidade de Natal, na África do Sul.

Dois fatores primordiais teriam condicionado este fato. $\mathrm{O}$ primeiro teria sido $\mathrm{o}$ aumento demográfico na região Nguni no século XVIII. Algo que se poderia explicar pela adoção do milho na base alimentar dos Nguni e outros povos da África Meridional. Secundariamente, teria ocorrido uma devastação progressiva das florestas na África Meridional, implicada pelo tipo de produção agrícola (queimadas e terras rotativas) e pastoreio nômade da região. Tais fatores teriam impulsionado a luta dos Nguni pela posse de novos recursos, que passaram a ser conquistados pela força (Ngcongco, 2010b, pp. 108-112).

Esta abordagem regionalista do Mfecane, para o autor, se oporia a duas outras interpretações possíveis. Por um lado, haveriam aquelas para as quais o Mfecane poderia ser explicado pela influência, direta ou indireta, dos imigrantes bôeres na região, por diversos fatores (exemplo de disciplina militar, expansão colonial, consolidação do comércio internacional etc). Por outro lado, o Mfecane seria explicado pela ação dos líderes africanos de então, que teriam criado novos modelos de estruturação política e militar para suas sociedades. O primeiro tipo de interpretação, para o autor, na melhor das hipóteses, seria infundado; na pior delas, tendencialmente racista. A segunda seria ingênua por explicar a sociedade pelo indivíduo, e não o contrário (Ngcongco, 2010b, pp. 112-113). Sobre este ponto, cito o próprio:

Em todo caso, é difícil levar muito a sério as explicações fundadas basicamente na personalidade ou nas qualidades individuais dos chefes

\footnotetext{
${ }^{70}$ Explicação em suas palavras:
}

Os primeiros decênios do século XIX foram marcados por uma poderosa revolução social e política, que, simultaneamente, teve por efeito a destruição e a reedificação da organização dos Estados na África Austral de língua banta, bem como a transformação das condições de existências de numerosas comunidades nos territórios que vão dos confins da Zululândia (Natal) até o Sul da Tanzânia. Esta revolução, denominada Mfecane (esmagamento) na língua nguni, também é conhecida sob o nome de Difaqane (golpe de martelo) em sotho-tswana

(Ngcongco, 2010b, p. 106). 
da revolução. É bem mais instrutivo tentar compreender porque chefes como Dingiswayo, Shaka, Mzilikazi e outros subiram ao poder e brilharam na mesma época e na mesma grande região. Uma reflexão deste tipo pode nos ajudar a evitar mitificar o papel de um ou outro dos principais atores desta grande tragédia humana e a ver neles, de forma mais razoável, o produto de um meio socioeconômico particular (Ngcongco, 2010b, p. 114).

Esta citação não serve apenas para exemplificar, por contraponto, a argumentação do autor. Mas também por trazer uma crítica direta ao tipo de abordagem do sujeito africano, já destacada. Isto porque, para muitos artigos da $H G A$, as transformações sociais essenciais das sociedades africanas do século XIX poderiam ser creditadas, fundamentalmente, à ação de importantes personagens históricos. Como se viu no capítulo precedente, tal interpretação é especialmente recorrente nos estudos que tratam de Muhammad 'Alī no Egito, Teodoro e Johannès IV na Etiópia, Shaka na África Austral e os principais líderes das jihad's na África Ocidental: 'Uthmān dan Fodio, Seku Ahmadu e Hadjdj 'Umar.

Em verdade, tratando de regiões africanas específicas, os autores ora citados (Ngcongco, Bhila e Cohen) trazem elementos para uma visão alternativa do século XIX africano, para além desta história do sujeito - centrada nas figuras de época - e do difusionismo intra-africano, que aí destaca a crescente influência europeia, com a chegada dos missionários, o comércio legal etc. Todavia, é certo que tais autores citados não pretendem generalizar suas conclusões. Pelo contrário, seus artigos se colocam no plano do específico.

Na $H G A$, entretanto, há um ensaio interessante desde tal perspectiva regionalista, com pretensões generalistas em sua interpretação. Trata-se do ensaio de A. Ajayi, escrito como conclusão para o Volume VI da obra (Conclusão: a Africa às vesperas da conquista europeia). Neste texto Ajayi defende que o papel de liderança dos soberanos africanos, no século XIX, deveria ser entendido em seu contexto próprio, que ele caracteriza como a busca das sociedades africanas pelo auto-desenvolvimento. O autor atribui esta busca por uma renovação continental à "evolução geral dos povos africanos". Mas destaca que o século XIX teria sido um período de aceleração das mudanças, marcado pela conjunção de alguns aspectos primordiais, como a abolição do tráfico escravista e a formação de uma classe de negociantes africanos associada ao “comércio legal” (Ajayi, 2010b, p. 909). 
Todavia, diz o autor, o elemento central desta ruptura histórica não teria ainda sido suficientemente explorado. Ele está se referindo à transformação das esferas de poder, fenômeno que, para o autor, teria ocorrido em boa parte das sociedades africanas entre fins do século XVIII e início do século XIX. Isto teria ocorrido, segundo Ajayi, porque nesta época as tropas armadas africanas teriam deixado de ser milícias ocasionais, formadas pelos corpos de cavalaria e camponeses armados, para se transformar em infantarias, formadas por guerreiros profissionais. Aí estaria, em última instância, a origem deste fortalecimento do Estado na África, consolidado e expandido no século XIX (Ajayi, 2010b, pp. 914-918).

Desde então, diz Ajayi, teria ocorrido uma transformação das elites africanas, visto que aqueles que passaram a deter o poder sobre estas novas estruturas estatais e militares teriam se afirmado contra as velhas aristocracias, cuja influência seria garantida pelo grande número de esposas e pela importância da rede familiar. Ter-se-ia formado, pois, uma nova aristocracia africana, não mais apoiada em redes parentais propriamente ditas, mas, antes, em vastas "famílias" de "clientes" e cativos. Estes novos aristocratas explorariam terras cuja superfície cresceria progressivamente, para assegurar não somente a subsistência do grupo familiar expandido, mas, também, a manutenção dos contingentes de guerreiros, quando o exército estivesse em campanha. Todos estes indivíduos, diz o autor, seriam empregados na produção de mercadorias destinadas a venda no mercado local e no grande comércio. Tal fato permitiria que estes novos aristocratas adquirissem os recursos financeiros necessários para atrair mais clientes e comprar armas e munições, geralmente importadas (Ajayi, 2010b, p. 919).

Diz o autor, portanto, que a emergência desta aristocracia teria impulsionado o auto-desenvolvimento das sociedades africanas no século XIX. Seria, por consequência, a base que teria permitido o surgimento de soberanos modernizantes africanos deste século (Muhammad 'Alī, Teodoro, Johannès IV, Shaka, Seku Ahmadu, Hadjdj 'Umar etc), contra quem os colonialistas tiveram que lutar para assegurar seus interesses. Evidentemente este novo quadro, como afirma ao próprio autor, não se reproduziu da mesma forma ou na mesma época no continente. Pelo contrário, em cada região ter-seiam verificado formas heterogêneas deste movimento de auto-desenvolvimento, através do fortalecimento do poder de Estado. Isto conforme a base ecológica, a infra-estrutura econômica, o desenvolvimento social, a estrutura política, as relações externas etc. Todavia, o quadro geral, para o autor, se manteria. 
Observa-se deste argumento de Ajayi um vislumbre do que seria uma abordagem regionalista da África do período histórico recente. Isto porque, ao destacar as tentativas de auto-desenvolvimento africano do século XIX - tendo o fortalecimento do Estado como o elemento central da dinâmica histórica desta época -, ele cria uma saída teórica original para o regionalismo, para o estudo histórico do mundo contemporâneo $^{71}$.

$\mathrm{Na} H G A$, entretanto, esta história recente do regionalismo na África não se estende ao século XX. Afinal, de fato, são ínúmeros os elementos e fatores externos e supra-regionais que tornam praticamente impossível a realização de tal história. Sobretudo por conta do colonialismo na África. Se há, portanto, uma história da África regionalista do século $\mathrm{XX}$, ela não está presente na $H G A$. Sobre isto, apenas o difusionismo intra-africano e o sujeito africano, tem algo a dizer.

\subsection{Considerações parciais}

Esta análise da abordagem regionalista da perspectiva africana, na $H G A$, levou à construção de uma periodização específica da história da África: a) Neolítico e África Antiga (10 mil - XII d. C); b) África entre os séculos XII-XIX.

O primeiro período tratado, entre o Neolítico e a África Antiga, é visto pelo regionalismo como um longo processo de sedentarização dos povos africanos. Este processo, evidentemente, não seria homogêneo no continente. Alguns povos, como os egípcios e os cuxitas tornaram-se pioneiros nesta sedentarização e no desenvolvimento de sociedades complexas. Outros, como os povos da África Sub-Equatorial, só teriam iniciado a formação destas sociedades em fins do primeiro milênio da Era presente.

Todavia, independentemente destas diferenciações temporais, o certo é que, no século XII na África, este processo de sedentarização já estaria concluído, como provariam as evidências linguísticas, arqueológicas e literárias advindas das fontes

\footnotetext{
${ }^{71}$ Daí se entende o posicionamento de J. F. A. Ajayi (“Colonialism: an episode in African history". In: L. H. GANN e P. DUIGNAN. (Orgs). Colonialism in Africa. v. I: The History and Politics of Colonialism, 1870-1914.1969, pp. 497-509), quando este afirma que o impacto do colonialismo na África tem sido exagerado; pois o colonialismo "representa apenas um episódio em uma longa e rica história" e não provocou ruptura histórica; os africanos conservaram certo poder de controle sobre seu próprio destino e, por fim, "na medida em que eles conservaram a iniciativa, os europeus não conseguiram imprimir orientação inteiramente nova a história da África" (Ajayi Apud Boahen, 2010e, p. 947).
} 
árabes. Os artigos aqui tipificados como regionalistas se esforçaram para caracterizar este processo como evoluções singulares da adequação do Homem aos seus ecossistemas. Utilizaram-se, para isto, da metalurgia do ferro, da formação de complexos agrícolas próprios, da domesticação e pastoreio de animais etc. Por isto, este século é aqui considerado um marco na periodização da história da África, desde uma abordagem regionalista. Afinal, o fator primordial da dinâmica dos povos africanos seria local, e não produto da difusão de fatores extra-regionais, como o comércio mundial ou o islamismo.

Nesta periodização, o século XII não marca apenas o final de uma Era, mas o início de outra, caracterizada pela generalização das sociedades complexas na África. Em suma, a partir de então, o regionalismo iria investigar, na longa duração, como o Homem, nestas sociedades, continuaria realizando, em um nível mais elevado, tal adequação ao meio em que vive.

Para os regionalistas, este processo evolutivo ver-se-ia interrompido, na maior parte da África, apenas em fins do século XIX. Evidentemente, fatos históricos como a peste negra, o tráfico escravista, as fomes periódicas, trouxeram elementos de involução em regiões do continente em épocas anteriores ao século $\mathrm{XIX}^{72}$. Entretanto, para a África como um todo seria apenas com o colonialismo que os povos africanos teriam de fato involuido, na medida em que perderam a sua soberania alimentar, econômica, política etc. Desde então, para os autores da $H G A$, não há um regionalismo possível nesta história.

Na medida em que não há um regionalismo do século $\mathrm{XX}$, na $H G A$, deve-se pensar sobre um princípio da complementaridade das abordagens analisadas, como algo central à perspectiva africana, aqui analisada. Sobre este e outros pontos, faremos, enfim, algumas considerações finais.

\footnotetext{
${ }^{72}$ Alguns artigos da $H G A$ apontam nesta direção tratando de épocas anteriores ao século XX, enfocando fenômenos ainda poucos estudados, mas que tiveram grande consequiência na história dos povos africanos, como fatores climáticos (sobretudo secas), ecológicos, epidemológicos (peste negra, malária, varíola) e de carência alimentar conjuntural. Com isto, visam compreender particularidades da história da região em estudo. Destaca-se, neste particular, três artigos do Volume V da HGA: M. Abitibol ( $O$ fim do Império Songhai), J. B. Webster, B. A. Ogot \& J. P. Chretien (A região dos Grandes Lagos, de 1500 a 1800), M. Cherif (Argélia, Tunísia e Líbia: os otomanos e seus herdeiros). Entrementes, mesmo nestes, seria errôneo dizer que tais elementos são aí tidos como fatores essenciais de explicação histórica.
} 


\section{Considerações finais}

O objetivo primordial desta tese era dar uma definição da perspectiva africana, comprovar a veracidade da mesma e delinear as abordagens que ela trouxe para a história da África, tendo por foco a $H G A$. Para cumprir este objetivo se realizou uma investigação holística e empírica da referida obra, que abarcou a organização institucional do projeto que lhe deu origem e a análise de sua escrita da história, em seus oito volumes.

Do conjunto desses dados, se definiu a perspectiva africana como a perspectiva que privilegia os fatores internos ao continente, em oposição aos externos, na explicação histórica, científica, da África. Tal definição foi defendida por dois argumentos primordiais. Em primeiro lugar, ela responde a um desafio proposto pelos próprios organizadores da $H G A$ : escrever uma história da África por ela mesma, desde uma perspectiva científica. Em segundo lugar, tal definição é uma totalidade suficientemente elástica para abarcar a diversidade de posições internalistas existentes na obra.

Ao longo deste trabalho, se buscou mostrar que esta diversidade da perspectiva africana, na $H G A$, pode ser sintetizada em três abordagens internalistas da história da África: a) difusionismo intra-africano; b) sujeito africano; c) regionalismo. Neste sentido, se dedicou um capítulo para cada uma destas abordagens, que foram analisadas pormenorizadamente. Afinal, elas são o conteúdo efetivo desta perspectiva africana.

Nestas considerações finais cabe destacar os pontos primordiais que definem, tipicamente, tais abordagens, assim como o conteúdo e a periodização que elas trouxeram para a história da África, a partir da $H G A$.

Como dito, o difusionismo intra-africano foi a abordagem mais presente nesta obra. Se definiu-o como um tipo de explicação histórica em que as dinâmicas fundamentais da história da África seriam derivadas da difusão de certos elementos considerados essenciais à evolução dos povos e sociedades dentro do próprio continente africano. Destaca-se aí, portanto, a ideia de movimento e troca na explicação histórica, assim com os fatos que atestariam tal interpretação. Seus temas típicos são os 
movimentos populacionais, as redes econômicas e as influências culturais de alguns povos africanos sobre outros.

A análise dessa abordagem, na $H G A$, permitiu a seguinte periodização histórica: a) Neolítico e África Antiga (10 mil - VI d. C; b) África entre os séculos VII-XVI; c) África entre o século XVII e 1880; d) África entre 1880 e os dias atuais.

Em que se baseia tal periodização? Para o período antigo da África, entre o Neolítico e o século VI (d. C), esta visão histórica está calcada em dois temas fundamentais: os movimentos populacionais e o comércio internacional. São duas temáticas que continuam firmes nessa versão da história da África até fins do século XIX. Sendo que a ruptura do século VII se justificaria pela expansão do Islamismo na África. Isto ocorre porque, segundo os autores que defendem tal interpretação histórica na $H G A$, a religião islâmica e o complexo cultural do qual ela faria parte teriam sido fatores centrais da consolidação e evolução das sociedades complexas no continente até, pelo menos, o século XVI. Concomitantemente, para os difusionistas intra-africanos este século seria também relevante como o início de uma nova etapa da história da África, com a consolidação do tráfico escravista e a expansão econômica europeiaocidental no continente. Tal visão da história se mantém nesses parâmetros até fins do século XIX, com o advento do colonialismo. Com a entrada deste novo ator em cena os elementos antes tidos como essenciais para a história da África - comércio mundial, tráfico escravista, islamismo, movimentos populacionais - tornam-se praticamente irrelevantes na história difusionista da $H G A$. Estes são então substituídos por outros, direta ou indiretamente derivados do sistema colonial, como a formação de novas camadas sociais, a ascensão do urbano frente ao mundo rural, o aprofundamento da dependência econômica, a reprodução da educação colonial, o desafio demográfico etc.

A constatação destes fatos leva a perceber que, nesta visão da história, há dois fatos históricos originalmente externos que deveriam ser vistos como rupturas decisivas na história da África. O primeiro seria o islamismo. O segundo, mais marcante, o colonialismo.

Uma história da África diferente se desvelou da abordagem do sujeito africano. Por sujeito africano, nesta tese, se entendeu uma explicação da história que visa 
destacar, sobretudo, a ação política do africano, contra a determinação dos fatores externos, como o elemento essencial da história da África.

Esta abordagem trouxe a seguinte periodização: a) A experiência egípciofaraônica (3.200 a. C. - 332 a. C); b) A civilização berbere-magrebiana (146 a. C. século XIV d. C.); c) As diásporas africanas (VII - XX); d) As resistências africanas contra o colonialismo e o neo-colonialismo europeu (XIX e XX).

Nas considerações parciais dessa abordagem, se observou que a sua substância essencial - a ação política africana - se concretiza sempre em relação a um Outro, que não se mantém estático, podendo se corporificar em formas diversas. Em relação à experiência egípcio-faraônica, por exemplo, se falou desse sujeito em oposição aos povos indo-europeus (semíticos, gregos, "mediterrânicos" etc). O mesmo teria ocorrido em relação ao sujeito da civilização berbere-magrebiana. Ele se forma na luta contra os invasores do Magreb: romanos, árabes, vikings, bizantinos, italianos, portugueses, espanhóis etc. Neste contexto, o Islã é visto como elemento fundamental desta luta e se integra a tal história. Concomitantemente, falou-se do sujeito da diáspora que se concretiza na luta contra os escravismos. Em particular os escravismos americanos. Por fim, na última periodização referida, se focou a resistência africana contra o colonialismo e o neo-colonialismo.

Vale lembrar que, apesar dessa aparente heterogeneidade do sujeito africano, se destacou que haveria uma continuidade essencial desse Outro, contra quem se forma o sujeito africano. Trata-se do fato de que este Outro seria, em verdade, o ocidental ${ }^{73}$. Ele seria a oposição que cria o sujeito africano em sua diversidade, negra ou berberemagrebiana.

Por fim, se analisou a abordagem do regionalismo, como parte da perspectiva africana. Resumidamente, trata-se de investigação que foca a longa duração, em que os fatores de adequação ecossistemica dos povos sobre o seu meio circundante se tornam os elementos dominantes na explicação histórica. Os objetos de estudo primordiais desta abordagem seriam o ecossistema local (ou regional) e os desenvolvimentos técnicos e sócio-políticos das populações africanas.

\footnotetext{
${ }^{73}$ Como sinônimo dessa imagem fantasmagórica associada aos europeus e seus descendentes, trazida pela abordagem do sujeito africano.
} 
Essa abordagem também possibilitou uma periodização da história da África: a) Neolítico e África Antiga (10 mil a. C. - XII d. C); b) África entre os séculos XII-XIX. O primeiro período tratado, entre o Neolítico e a África Antiga, é visto pelo regionalismo como um longo processo de sedentarização dos povos africanos. Este processo não seria homogêneo no continente. Todavia, independentemente destas diferenciações temporais, o certo é que, no século XII na África, ele já estaria concluído. Sobretudo como evoluções singulares da adequação do Homem aos seus ecossistemas, com a utilização da metalurgia do ferro, formação de complexos agrícolas próprios, domesticação e pastoreio de animais.

Nesta periodização, portanto, o século XII não marca apenas o final de uma Era, mas o início de outra, caracterizada pela generalização das sociedades complexas na África. Em suma, a partir de então, o regionalismo vai investigar como o Homem na longa duração, nestas sociedades, vai continuar realizando num nível mais elevado esta adequação ao meio em que vive.

Para os regionalistas este processo evolutivo é interrompido em fins do século XIX com a instauração do colonialismo. Isto seria fundamental porque desde então os povos africanos teriam perdido boa parte de sua soberania. E, portanto, a capacidade de se auto-determinar. Assim, para os autores da $H G A$, não haveria um regionalismo possível na história contemporânea da África.

Esta síntese permite, afinal, algumas considerações comparativas sobre as principais continuidades e descontinuidades presentes na perspectiva africana, na $H G A$. Em relação à periodização as descontinuidades são bem maiores do que as continuidades. Para ser preciso, o único ponto comum são os pontos (d) do difusionismo intra-africano e do sujeito africano, que destacam a crescente influência do colonialismo desde meados do século XIX (no Magreb e no Egito) como uma ruptura na história da África, por razões diversas. Será que tal fato implica diferenças primordiais de conteúdo da história da África?

Em grande parte sim, pelos menos em relação ao que se destaca nos estudos sobre história da África. Para o difusionismo intra-africano os movimentos populacionais, o comércio mundial, o islamismo e o colonialismo, seriam fatos históricos essenciais na história da África. Desde outro ponto de vista, para o sujeito africano, os fatos históricos relevantes são a assunção política contra os colonialismos "ocidentais": indo-europeu, mediterrânico, romano, europeu, euro-descendente. Para os 
regionalistas, no entanto, o único fato fundamental nesta história seria a generalização das sociedades complexas no continente a partir do século XII. A escolha entre esses tipos de periodização (ou outras aproximadas) implica considerações epistemológicas e metodológicas que devem ser precisadas.

Uma conclusão importante deste trabalho é que de acordo com a diretriz aqui trabalhada, a perspectiva africana, o regionalismo é a abordagem mais coerente para a história da África, entre as citadas. A razão primordial para esta afirmação é que ela é a única que consegue estabelecer uma periodização histórica cujo conteúdo justifica, plenamente, uma visão internalista da África: a adequação ecossistemica na longa duração. Afinal, a maioria dos elementos referentes tanto ao difusionismo intraafricano, quanto à abordagem do sujeito, em última instância, dependem de fatores, direta ou indiretamente, exteriores ao continente para se afirmar: o comércio mundial, o islamismo, o colonialismo europeu, os colonialismos ocidentais. Neste sentido, pode-se concluir que o regionalismo é a base primeira de uma história internalista da África. Ele é o lugar primordial de onde ver a África que existe para além da determinação externa. É o cerne, portanto, da perspectiva africana.

Dizer isto, todavia, não implica considerar desnecessário a tal perspectiva as demais abordagens citadas. Pelo contrário. Deve-se defender o oposto por duas questões primordiais. A primeira é que, se assim o fosse, dever-se-ia admitir que uma história internalista da África não tem nada a dizer sobre a época colonial e pós-colonial da África, o que seria absurdo. Afinal, como visto, não há uma história regionialista deste período em África, pelo menos na $H G A$. Essa ausência, portanto, faz com que, obrigatoriamente, o difusionismo intra-africano e/ou a abordagem do sujeito sejam interpretações necessárias à história da África recente, desde um ponto de vista internalista. Secundariamente, deve-se admitir que essa periodização possibilitada pelo regionalismo é uma generalização da história da África - e assim deve ser entendida. Portanto, a importância de fatores conjunturais, tais como os trazidos pelo difusionismo intra-africano e a abordagem do sujeito, podem ser fundamentais para a explicação histórica de um determinado lugar e época específicos. Por exemplo, o que seria uma análise das diásporas africanas sem a abordagem do sujeito? Ou como se poderia explicar a história de sociedades como Angola, Senegâmbia ou Delta do Níger, no século XVII, sem recorrer à abordagem difusionista, que destaque, por exemplo, as redes comerciais do tráfico escravista? 
Considerações como essas mostram que as demais abordagens citadas - o difusionismo intra-africano e o sujeito - são interpretações que enriquecem e trazem cientificidade à perspectiva africana. Não são abordagens opostas. São complementares. Sendo que essa complementaridade possui uma direção definida: do regionalismo às demais abordagens citadas.

Sobre este assunto particular, resta pesar se haveria alguma ordem de prioridade entre o difusionismo intra-africano e o sujeito, como abordagens complementares ao regionalismo, a partir da perspectiva africana. Em outras palavras, seria uma dessas abordagens mais adequada ao viés internalista da histórida da África, do que a outra? De um ponto de vista lógico, pelo que foi exposto, deve-se concluir que por enfatizar a história dos movimentos populacionais africanos o difusionismo intra-africano é um tipo de abordagem mais internalista do que a do sujeito africano. Mas apenas por este elemento específico. Pois, de um modo geral, os demais elementos do difusionismo intra-africano, como o islamismo, o comércio mundial e o colonialismo, direta ou indiretamente, dependem, em ultima instância, da existência de fatores externos à própria África. E, por consequência, em relação a estes elementos não há motivos para hierarquizar as abordagens citadas. Seja como for, elas são formas possíveis da perspectiva africana que devem ser utilizadas de forma complementar ao regionalismo. Este sim, um internalismo de fato.

Esta constatação implica que uma ênfase coerente na perspectiva africana inverta a ordem de prioridade das abordagens existentes na $H G A$, visto que, aí, o difusionismo intra-africano e o sujeito são quantitativamente dominantes na obra. Afinal, a partir da perspectiva africana, o regionalismo deveria ser a abordagem dominante na obra. Sendo complementado, quando necessário, pelo difusionismo intra-africano e/ou a abordagem do sujeito.

Concluindo, nestas considerações finais, cabe sintetizar quais as consequências teóricas e metodológicas que a opção epistemológica e metodológica pela perspectiva africana implica. A essência desta perspectiva é que ela é uma visão científica da história. São vários os pontos neste sentido. Antes de qualquer coisa, sua própria existência, assim como a sua demonstração, é baseada em trabalho empírico. Isso significa que ela pode, em princípio, ser contestada por qualquer outro pesquisador da área. Ela é uma verdade não dogmática, verificável, algo que se julga importante para a 
comprovação científica do argumento central desta tese. Por outro lado, trata-se de uma prerrogativa historiográfica universalista que pode ser utilizada e refinada por pesquisadores de todo o mundo, independente de sua pertença nacional, étnico-racial ou mesmo ideológica. Afinal, o que a define é um procedimento metodológico. Em terceiro lugar, é uma visão histográfica interdisciplinar que julga poder distinguir o essencial do secundário na explicação histórica. Ademais, esta visão se ancora em uma concepção materialista, realista e empírica, do trabalho historiográfico - como em toda a $H G A$. Em quinto lugar, trata-se de um método específico: o internalismo da perspectiva africana. Neste, se inicia pela adoção de uma abordagem regionalista, complementando-a quando necessário com o difusionismo intra-africano e a abordagem do sujeito. Tal hierarquização metodológica (e de conteúdo) não está presente na $H G A$, mas é uma conclusão lógica deste trabalho.

Estes cinco pontos, portanto, sintetizam a perspectiva africana, que aqui se analisou: a) definição verificável; b) princípio universalista; c) separação entre o essencial e o secundário na explicação histórica; d) história interdisciplinar, materialista, realista e empirica; e) método internalista: do regionalismo ao difusionismo intraafricano e ao sujeito.

Esse último item da perspectiva africana permite situá-la no campo mais amplo das possíveis alternativas contemporâneas ao paradigma eurocêntrico dentro das ciências em geral e da ciência histórica em particular. Neste contexto, ela se coloca como uma alternativa tanto ao relativismo, quanto ao positivismo dominantes na teoria social contemporânea. Afinal, a perspectiva africana é um híbrido, um perspectivismo científico. Ela parte de um pressuposto científico que envolve empiria, interdisciplinaridade e uma visão materialista e realista da História. Todavia, acredita que este ideal regulador deve ser guiado por um método internalista trazido por seu próprio objeto de estudo. Neste caso, a história da África.

Por estas duas características defende-se a univesalidade da perspectiva africana, conforme aqui analisada. Não porque ela traga uma nova história universal, um mero disfarce mais ou menos sofisticado de uma nova história particular: europeia, ocidental, euro-asiática. Mas porque ela, por seu método (internalista) e ideal regulador (ciência histórica), potencializa o conhecimento derivado do estudo das particularidades. 
Atribuir valor a esta descoberta, entretanto, talvez dependa do fato de que se acredite que a ciência seja ainda um locus de enunciação relevante - embora não único para a auto-determinação dos povos e das sociedades. O autor destas linhas não tem dúvidas a este respeito. Todavia, adentrar nesta discussão seria extrapolar as restrições acadêmicas, que nós impusemos neste trabalho. 


\section{Referências}

I - Fontes documentais citadas:

UNESCO (1966a). UNESCO-CLT-HIGENAF-ABIDJAN-3.

Disponível em: http://unesdoc.unesco.org/images/0014/001432/143293eb.pdf. Acesso em 09/10/2009.

UNESCO (1966b). UNESCO-SHC-2.

Disponível em: http://unesdoc.unesco.org/images/0012/001279/127997eb.pdf. Acesso em: 09/10/2009.

UNESCO (1970a). 85 EX-Decisions.

Disponível em: http://unesdoc.unesco.org/images/0011/001131/113198Eb.pdf. Acesso em: 09/10/2009.

UNESCO (1970b). SHC-MD-10.

Disponível em: http://unesdoc.unesco.org/images/0012/001269/126966eb.pdf. Acesso em: 09/10/2009.

UNESCO (1970c). SHC- CONF- 66.

Disponível em: http://unesdoc.unesco.org/images/0000/000000/000090eb.pdf. Acesso em: 09/10/2009.

UNESCO (1971). SHC-MD-16.

Disponível em: http://unesdoc.unesco.org/images/0000/000002/000233eb.pdf. Acesso em: 10/10/2009.

UNESCO (1975a). SHC-75-CONF. 601-2. 
Disponível em: http://unesdoc.unesco.org/images/0001/000118/011828eb.pdf. Acesso em 10/10/2009.

UNESCO (1975b). SHC-75-CONF. 611-2.

Disponível em: http://unesdoc.unesco.org/images/0001/000120/056845eb.pdf. Acesso em 10/10/2009.

UNESCO (1976). CC-CS-76-WS-18.

Disponível em: http://unesdoc.unesco.org/images/0002/000213/021386eb.pdf. Acesso em: 10/10/2009.

UNESCO (1977a). CC-77-CONF.602-1.

Disponível em: http://unesdoc.unesco.org/images/0003/000324/032484eb.pdf. Acesso em 10/10/2009

UNESCO (1977b). CC-77-CONF.602-2.

Disponível em: http://unesdoc.unesco.org/images/0003/000324/032498fb.pdf. Acesso em 10/10/2009.

UNESCO (1978). CC-78-CONF. 607-3.

Disponível em: http://unesdoc.unesco.org/images/0003/000349/034909eb.pdf. Acesso em 10/10/2009.

UNESCO (1979a). CC -79-CONF. 608-1

Disponível em: http://unesdoc.unesco.org/images/0003/000371/037192eb.pdf. Acesso em: 10/10/2009.

UNESCO (1979b). 107 EX -13 
Disponível em: http://unesdoc.unesco.org/images/0003/000357/035760eb.pdf. Acesso em: 10/10/2009.

UNESCO (1980). CC-80-CONF. 508-1

Disponível em: http://unesdoc.unesco.org/images/0004/000420/042057eb.pdf. Acesso em 10/10/2009.

UNESCO (1982). CLT - $82-\mathrm{WS}-16$

Disponível em: http://unesdoc.unesco.org/images/0004/000493/049334eb.pdf. Acesso em 10/10/2009.

II - Entrevistas:

Série de três entrevistas realizadas em 2009 com o sociólogo e antropólogo Professor Doutor Fernando Augusto de Albuquerque Mourão. Professor Titular do Departamento de Sociologia. FFLCH-USP.

\section{III - Bibliografia:}

ABDEL-MALEK, A. O renascimento do Egito (1805-1881). In: AJAYI, J. F. A. (Ed.). África do século XIX à década de 1880. 2a . ed. rev. Brasília: UNESCO, 2010.

ABITBOL, M. O fim do Império Songhai. In: OGOT, B. A. (Ed.). África do século XVI ao século XVIII. $2^{\mathrm{a}}$. ed. rev. Brasília: UNESCO, 2010.

ADAM, S. A importância da Núbia: um elo entre a África central e o Mediterrâneo. In: MOKHTAR, G. (Ed.). A África Antiga. 2a . ed. rev. Brasília: UNESCO, 2010. 
ADAMU, M. Os Haussa e seus vizinhos do Sudão central. In: NIANE, D. T. (Ed.). África do século XII ao século XVI. 2a . ed. rev. Brasília: UNESCO, 2010.

ADEDEJI, A. Estratégias comparadas da descolonização econômica. In: MAZRUI, A. A. \& WONDJI, C. (Ed.). A África desde 1935. 2ª ed. rev. Brasília: UNESCO, 2010.

AFIGBO, A. E. Repercussões sociais da dominação colonial: novas estruturas sociais. In: BOAHEN, A. A. (Ed.). A África sob dominação colonial: 1880-1935. 2a . ed. rev. Brasília: UNESCO, 2010.

AJAYI, J. F. A. África no início do século XIX: problemas e perspectivas. In: AJAYI, J. F. A. (Ed.). África do século XIX à década de 1880. 2ª ed. rev. Brasília: UNESCO, 2010a.

Conclusão: a África as vésperas da conquista europeia. In: AJAYI, J. F. A. (Ed.). África do século XIX à década de 1880. 2a . ed. rev. Brasília: UNESCO, 2010b.

AKPAN, M. B. \& PANKHURST, R. A Etiópia e a Libéria, 1914-1935: dois Estados africanos independentes na era colonial. In: BOAHEN, A. A. (Ed.). A África sob dominação colonial: 1880-1935. 2a . ed. rev. Brasília: UNESCO, 2010.

; JONES, A. B. \& PANKHURST, R. Libéria e Etiópia, 1880- 1914: a sobrevivência de dois Estados africanos. In: BOAHEN, A. A. (Ed.). A África sob dominação colonial: 1880-1935. 2a . ed. rev. Brasília: UNESCO, 2010.

ALAGOA, E. J. Do delta do Níger aos Camarões: os fon e os iorubas. In: OGOT, B. A. (Ed.). África do século XVI ao século XVIII. 2ª . ed. rev. Brasília: UNESCO, 2010.

; ELANGO, L. Z. \& N’NAH, N. M. O delta do Níger e Camarões. In: AJAYI, J. F. A. (Ed.). África do século XIX à década de 1880. 2ª . ed. rev. Brasília: UNESCO, 2010. 
AMIN, S. Eurocentrismo: crítica de uma ideologia. Lisboa: Dinossauro, 1994.

ANFRAY, F. A civilização de Axum do século I ao século VII. In: MOKHTAR, G. (Ed.). A África Antiga. 2ª ed. rev. Brasília: UNESCO, 2010.

ARHIN, K. \& KI-ZERBO, J. Estados e povos do Arco do Níger e do Volta. In: AJAYI, J. F. A. (Ed.). África do século XIX à década de 1880. 2a . ed. rev. Brasília: UNESCO, 2010 .

ARÓSTEGUI, J. A pesquisa histórica: teoria e método. Bauru, SP: EDUSC, 2002.

ASANTE, M. K. The History of Africa: the quest for eternal harmony. NY: Routledge, 2007.

ASANTE, S. K. B. \& CHANAIWA, D. O Pan-africanismo e a Integração Regional. In: MAZRUI, A. A. \& WONDJI, C. (Ed.). A África desde 1935. 2a . ed. rev. Brasília: UNESCO, 2010.

ASIWAJU, A. Daomé, país iorubá, Borgu (Borgou) e Benim no século XIX. In: AJAYI, J. F. A. (Ed.). África do século XIX à década de 1880. 2ª . ed. rev. Brasília: UNESCO, 2010.

ATIENO-ODHIAMBO, E. S. Política e o nacionalismo na África oriental, 1919-1935. In: BOAHEN, A. A. (Ed.). A África sob dominação colonial: 1880-1935.2ª . ed. rev. Brasília: UNESCO, 2010.

AUSTEN, R. African economic history: internal development and external dependency. London/Portsmouth, NH: James Currey/Heineman, 1996.

BÃ, A, H. A tradição viva. In: KI-ZERBO, Joseph (Ed.). Metodologia e Pré-história da África. $2^{\mathrm{a}}$. ed. rev. Brasília: UNESCO, 2010. 
BAIER, S. O Saara no século XIX. In: AJAYI, J. F. A. (Ed.). África do século XIX à década de 1880. $2^{\mathrm{a}}$. ed. rev. Brasília: UNESCO, 2010.

BAKR, A. B. O Egito faraônico. In: MOKHTAR, G. (Ed.). A África Antiga. 2a . ed. rev. Brasília: UNESCO, 2010.

BALOUT, L. \& COPPENS, Y. Parte II: Quadro cronológico das fases pluviais e glaciais da África. In: KI-ZERBO, Joseph (Ed.). Metodologia e Pré-história da África. $2^{a}$. ed. rev. Brasília: UNESCO, 2010.

- Parte II: A hominização: problemas gerais. In: KI-ZERBO, Joseph (Ed.). Metodologia e Pré-história da África. 2a. ed. rev. Brasília: UNESCO, 2010a.

Pré-História da África do Norte. In: KI-ZERBO, Joseph (Ed.). Metodologia e Pré-história da África. 2a . ed. rev. Brasília: UNESCO, $2010 \mathrm{~b}$.

BARBOSA, M. S. Eurocentrismo, história e história da África. Sankofa: história da África e Estudos da Diáspora Africana. NEACP-FFLCH-USP. No, 1, Vol. 1., 2009.

BARBOSA, W. N. A dialética como método e como lógica (mimeo), 1991. Disponível em: https://sites.google.com//dnbwilson/textosdeteoriaemetodologia. Acesso em 03 de Fev. de 2011.

BARKINDO, B. O Kanem-Bornu: suas relações com o Mediterrâneo, o Baguirmi e os outros Estados da bacia do Chade. In: OGOT, B. A. (Ed.). África do século XVI ao século XVIII. $2^{\mathrm{a}}$. ed. rev. Brasília: UNESCO, 2010.

BARRY, B. A Senegâmbia do século XVI ao XVIII: a evolução dos Wolofes, dos Sereres e dos Tucolores. In: OGOT, B. A. (Ed.). África do século XVI ao século XVIII. $2^{\mathrm{a}}$. ed. rev. Brasília: UNESCO, 2010. 
- Senegâmbia: o desafio da História Regional. Rio de Janeiro: SEPHIS/CEAA (UCAM), 2000.

BATHILY, A. \& MEILLASSOUX, C. As relações entre as diferentes regiões da África. In: FASI, M. El. (Ed.). África do século VII ao século XI. 2ª ed. rev. Brasília: UNESCO, 2010.

BATRAN, A. A. As revoluções islâmicas do século XIX na África do Oeste. In: AJAYI, J. F. A. (Ed.). África do século XIX à década de 1880. 2ª ed. rev. Brasília: UNESCO, 2010.

BERQUE, J. Política e nacionalismo no Maghreb e no Saara, 1919-1935. In: BOAHEN, A. A. (Ed.). A África sob dominação colonial: 1880-1935. 2a . ed. rev. Brasília: UNESCO, 2010.

BRETT, M. UNESCO General History of Africa. Vol. II. Ancient Civilizations of Africa by G. Mokhtar. The Journal of African History, 23, 1(1982), p. 117-120.

BETTS, R. F. \& ASIWAJU, A. A dominação europeia: métodos e instituições. In: BOAHEN, A. A. (Ed.). A África sob dominação colonial: 1880-1935. 2a . ed. rev. Brasília: UNESCO, 2010.

BHEBE, N. M. Os britânicos, os bôeres e os africanos na África do Sul 1850-1880. In: AJAYI, J. F. A. (Ed.). África do século XIX à década de 1880. 2ª . ed. rev. Brasília: UNESCO, 2010.

BHILA, H. H. K. A região ao Sul do Zambeze. In: OGOT, B. A. (Ed.). África do século XVI ao século XVIII. 2a . ed. rev. Brasília: UNESCO, 2010.

BIANQUIS, T. O Egito desde a conquista árabe até o final do Império Fatímida (1171). In: FASI, M. El. (Ed.). África do século VII ao século XI. 2 ${ }^{\mathrm{a}}$. ed. rev. Brasília: UNESCO, 2010. 
BLACKBURN, S. Dicionário Oxford de Filosofia. Rio de Janeiro: Jorge Zahar, 1997.

BLAUT, J. Eight Eurocentric Historians. NY: Guilford Press, 2000.

BOAHEN, A. A. Os Estados e as culturas da costa da Guiné Inferior. In: OGOT, B. A. (Ed.). África do século XVI ao século XVIII. 2a . ed. rev. Brasília: UNESCO, 2010a.

Tendências e processos novos na África do século XIX. In: AJAYI, J. F. A. (Ed.). África do século XIX à década de 1880. 2a . ed. rev. Brasília: UNESCO, 2010b.

A África diante do desafio colonial. In: BOAHEN, A. A. (Ed.). A África sob dominação colonial: 1880-1935. 2ª . ed. rev. Brasília: UNESCO, 2010c.

Política e nacionalismo na África ocidental, 1919-1935. In: BOAHEN, A. A. (Ed.). A África sob dominação colonial: 1880-1935. 2a . ed. rev. Brasília: UNESCO, 2010d.

O colonialismo na África: impacto e significação. In: BOAHEN, A. A. (Ed.). A África sob dominação colonial: 1880-1935. 2ª ed. rev. Brasília: UNESCO, 2010e.

BUNGE, M. Caçando a realidade: a luta pelo realismo. São Paulo: Perspectiva, 2010.

BURKE, Peter. A Revolução Francesa da historiografia: a Escola dos Annales (19291989). São Paulo: UNESP, 1991.

CALDWELL, J. C. As repercussões sociais da dominação colonial: aspectos demográficos. In: BOAHEN, A. A. (Ed.). A África sob dominação colonial: 1880-1935. $2^{a}$. ed. rev. Brasília: UNESCO, 2010. 
CERULLI, E. As relações da Etiópia com o mundo muçulmano. In: FASI, M. El. (Ed.). África do século VII ao século XI. 2ª . ed. rev. Brasília: UNESCO, 2010.

CHANAIWA, D. \& KODJO, E. Pan-africanismo e libertação. In: MAZRUI, A. A. \& WONDJI, C. (Ed.). A África desde 1935. 2a . ed. rev. Brasília: UNESCO, 2010.

$$
\text { Iniciativas e resistência africanas na África meridional. In: }
$$

BOAHEN, A. A. (Ed.). A África sob dominação colonial: 1880-1935. 2a . ed. rev. Brasília: UNESCO, 2010a.

A África Austral. In: MAZRUI, A. A. \& WONDJI, C. (Ed.). A África desde 1935. $2^{\mathrm{a}}$. ed. rev. Brasília: UNESCO, $2010 \mathrm{~b}$.

CHENNTOUF, T. O chifre da África e a África setentrional. In: MAZRUI, A. A. \& WONDJI, C. (Ed.). A África desde 1935. 2a . ed. rev. Brasília: UNESCO, 2010.

CHÉRIF, M. H. Argélia, Tunísia e Líbia: os otomanos e seus herdeiros. In: OGOT, B. A. (Ed.). África do século XVI ao século XVIII. 2a . ed. rev. Brasília: UNESCO, 2010a.

Novos desenvolvimentos no Magreb: Argélia, Tunísia e Líbia. In: AJAYI, J. F. A. (Ed.). África do século XIX à década de 1880. 2ª ed. rev. Brasília: UNESCO, 2010b.

CHINWEIZU, D. A África e os países capitalistas. In: MAZRUI, A. A. \& WONDJI, C. (Ed.). A África desde 1935. 2ª . ed. rev. Brasília: UNESCO, 2010.

CISSOKO, S. M. Os Songhai do seculo XII ao XVI. In: NIANE, D. T. (Ed.). África do século XII ao século XVI. 2a . ed. rev. Brasília: UNESCO, 2010.

CLARK, J. D. Pré-História da África austral. In: KI-ZERBO, Joseph (Ed.). Metodologia e Pré-história da África. 2ª ed. rev. Brasília: UNESCO, 2010. 
CLARKE, J. H. Ancient civilizations of Africa: the missing pages in world history. Journal of African Civilisations, 4, 2, (November, 1982), p. 117-120.

COHEN, D. W. Povos e Estados da região dos Grandes Lagos. In: AJAYI, J. F. A. (Ed.). África do século XIX à década de 1880. 2a . ed. rev. Brasília: UNESCO, 2010.

CONTENSON, H. de. A cultura pré-axumita. In: MOKHTAR, G. (Ed.). A África Antiga. 2a. ed. rev. Brasília: UNESCO, 2010.

COPPENS, Y. Parte I: A hominização: problemas gerais. In: KI-ZERBO, Joseph (Ed.). Metodologia e Pré-história da África. 2ª ed. rev. Brasília: UNESCO, 2010.

COQUERY-VIDROVITCH, C. A economia colonial das antigas zonas francesas, belgas e portuguesas (1914-1935). In: BOAHEN, A. A. (Ed.). A África sob dominação colonial: 1880-1935. 2a . ed. rev. Brasília: UNESCO, 2010a.

As mudancas econômicas na África em seu contexto mundial (1935-1980). In: MAZRUI, A. A. \& WONDJI, C. (Ed.). A África desde 1935. 2a. ed. rev. Brasília: UNESCO, 2010 b.

CROWDER, M. A Primeira Guerra Mundial e suas consequências. In: BOAHEN, A. A. (Ed.). A África sob dominação colonial: 1880-1935. 2ª ed. rev. Brasília: UNESCO, 2010a.

A África sob domínio britânico e belga. In: MAZRUI, A. A. \& WONDJI, C. (Ed.). A África desde 1935. 2ª ed. rev. Brasília: UNESCO, $2010 \mathrm{~b}$.

CURTIN, P. D. Tendências recentes das pesquisas históricas africanas e contribuição à história em geral. In: KI-ZERBO, Joseph (Ed.). Metodologia e Pré-história da África. $2^{\mathrm{a}}$. ed. rev. Brasília: UNESCO, 2010.

DAGET, S. A abolição do tráfico de escravos. In: AJAYI, J. F. A. (Ed.). África do século XIX à década de 1880. 2a . ed. rev. Brasília: UNESCO, 2010. 
DALBY, D. Mapa linguístico da África. In: KI-ZERBO, Joseph (Ed.). Metodologia e Pré-história da África. 2a . ed. rev. Brasília: UNESCO, 2010.

DAVIDSON, B.; PÉLISSIER, R. \& ISAACMAN, A. Política e nacionalismo nas Áfricas central e meridional, 1919-1935. In: BOAHEN, A. A. (Ed.). A África sob dominação colonial: 1880-1935. 2a . ed. rev. Brasília: UNESCO, 2010.

DEBONO, F. Pré-História do vale do Nilo. In: KI-ZERBO, Joseph (Ed.). Metodologia e Pré-história da África. 2a . ed. rev. Brasília: UNESCO, 2010.

DENOON, D. A África Austral . In: OGOT, B. A. (Ed.). África do século XVI ao século XVIII. 2a . ed. rev. Brasília: UNESCO, 2010.

DEPELCHIN, J. Silences in african history: between the syndromes of dicovery and abolition. Dar Es Salaam: Mkuki Na Nyota Publishers, 2005.

DESANGES, J. Os protoberberes. In: MOKHTAR, G. (Ed.). A África Antiga. 2a . ed. rev. Brasília: UNESCO, 2010.

DEVISSE, J. \& HRBEK, I. Os almorávidas. In: FASI, M. El. (Ed.). África do século VII ao século XI. 2 ${ }^{\mathrm{a}}$. ed. rev. Brasília: UNESCO, 2010.

- \& VANSINA, J. A África do século VII ao XI: cinco séculos formadores. In: FASI, M. El. (Ed.). África do século VII ao século XI. 2a . ed. rev. Brasília: UNESCO, 2010.

. \& LALIB, S. A África nas relações intercontinentais. In: NIANE, D. T. (Ed.). África do século XII ao século XVI. 2ª . ed. rev. Brasília: UNESCO, 2010.

. (Redator). Anexo. Síntese do coloquio "O povoamento do antigo Egito e a decifração da escrita meroíta”. In: MOKHTAR, G. (Ed.). A África Antiga. 2a . ed. rev. Brasília: UNESCO, 2010a. 
. Comércio e rotas do tráfico na África Ocidental. In: FASI, M. El. (Ed.).

África do século VII ao século XI. 2ª . ed. rev. Brasília: UNESCO, 2010b.

DIAGNE, P. História e linguística. In: KI-ZERBO, Joseph (Ed.). Metodologia e Préhistória da África. 2a . ed. rev. Brasília: UNESCO, 2010a.

As estruturas políticas, econômicas e sociais africanas durante o período considerado. In: OGOT, B. A. (Ed.). África do século XVI ao século XVIII. 2a . ed. rev. Brasília: UNESCO, 2010b.

DIARRA, S. Geografia histórica: aspectos físicos. In: KI-ZERBO, Joseph (Ed.). Metodologia e Pré-história da África. 2a . ed. rev. Brasília: UNESCO, 2010.

DIOP, C. A. Origem dos antigos egipcios. In: MOKHTAR, G. (Ed.). A África Antiga. $2^{a}$. ed. rev. Brasília: UNESCO, 2010.

The african origin of civilization: myth or reality. NY: Lawrence Hill \& Company, 1973.

DIOP, M. et al. A África tropical e a África equatorial sob domínio francês, espanhol e português. In: MAZRUI, A. A. \& WONDJI, C. (Ed.). A África desde 1935. 2a . ed. rev. Brasília: UNESCO, 2010.

DIOUF, M. \& MBODJ, M. The Shadow of Cheikh Anta Diop. In: MUDIMBE, V. (ed.). The surreptitious speech: Présence Africaine and the politics of otherness 194787. Chicago and London: University of Chicago Press, 1992, pp. 118-136.

DJAIT, H. As fontes escritas anteriores ao século XV. In: KI-ZERBO, Joseph (Ed.). Metodologia e Pré-história da África. 2a . ed. rev. Brasília: UNESCO, 2010. 
DOMENICHINI-RAMIARAMANANA, B. Madagascar. In: FASI, M. El. (Ed.). África do século VII ao século XI. 2ª ed. rev. Brasília: UNESCO, 2010.

DONADONI, S. O Egito sob dominação romana. In: MOKHTAR, G. (Ed.). A África Antiga. $2^{\mathrm{a}}$. ed. rev. Brasília: UNESCO, 2010.

DOUGALL, A. M. The Sands of Time. UNESCO General History of Africa, Volume VI: Africa in the Nineteenth Century Until the 1880s by J. F. Ade Ajayi. The Journal of African History, Vol. 35, No. 2 (1994), pp. 314-316.

DRAMANI-ISSIFOU, Z. O Islã como sistema social na África, desde o século VII. In: FASI, M. El. (Ed.). África do século VII ao século XI. 2a . ed. rev. Brasília: UNESCO, 2010 .

DUSSEL, E. 1492: o encobrimento do outro. Petrópolis, RJ: Vozes, 1993.

EDMONSON, L. A África e as regiões em vias de desenvolvimento. In: MAZRUI, A. A. \& WONDJI, C. (Ed.). A África desde 1935. 2ª ed. rev. Brasília: UNESCO, 2010.

EHRET, C. O interior da África Oriental. In: FASI, M. El. (Ed.). África do século VII ao século XI. $2^{\mathrm{a}}$. ed. rev. Brasília: UNESCO, 2010.

. Entre a costa e os Grandes Lagos. In: NIANE, D. T. (Ed.). África do século XII ao século XVI. 2a . ed. rev. Brasília: UNESCO, 2010.

The civilizations of Africa: a history to 1800. Charlottesville: University of Virginia Press, 2002.

\& HOOVER, J. J. UNESCO General History of Africa, Vol. 1: Methodology and African Prehistory by J. Ki-Zerbo. African Studies Review, xxiv, 4 (1981), pp. 182-183. 
ELAIGWU, J. I. \& MAZRUI, A. A. Construção da nação e evolução das estruturas políticas. In: MAZRUI, A. A. \& WONDJI, C. (Ed.). A África desde 1935. 2ª ed. rev. Brasília: UNESCO, 2010.

ESCOAVELOMANDROSO, F. Madagascar e as ilhas vizinhas, do século XII ao XVI. In: NIANE, D. T. (Ed.). África do século XII ao século XVI. $2^{\mathrm{a}}$. ed. rev. Brasília: UNESCO, 2010.

ESCOAVELOMANDROSO, M. Madagascar de 1880 a 1939: iniciativas e reações africanas a conquista e a dominação coloniais. In: BOAHEN, A. A. (Ed.). A África sob dominação colonial: 1880-1935. 2a . ed. rev. Brasília: UNESCO, 2010.

EZE, E. C. El color de la razon: las ideias de "raza" em la antropologia de Kant. In: MIGNOLO, W. (comp.). Capitalismo e geopolítica del conocimiento: el eurocentrismo y la filosofia de la libertación en el debate intelectual contemporáneo. Buenos Aires: Del Signo, 2001, pp. 201-252.

FAGAN, B. M. As bacias do Zambeze e do Limpopo, entre 1100 e 1500. In: NIANE, D. T. (Ed.). África do século XII ao século XVI. 2a . ed. rev. Brasília: UNESCO, 2010.

FAGE, J. D. A evolução da historiografia da África. In: KI-ZERBO, Joseph (Ed.). Metodologia e Pré-história da África. 2a . ed. rev. Brasília: UNESCO, 2010a.

FALOLA, T. (Ed.). Africa: Volume 1: African History Before 1885. Durham, North Carolina: Carolina Academic Press, 2001.

\& JENNINGS, C. (Ed.). Sources and method in african history: spoken, written, unearthed. NY: University of Rochester Press, 2003. 
FASI, El. \& HRBEK I. O advento do Islã e a ascensão do Império Muçulmano. In: FASI, M. El. (Ed.). África do século VII ao século XI. 2a . ed. rev. Brasília: UNESCO, 2010a.

. Etapas do desenvolvimento do Islã e da sua difusão na África.

In: FASI, M. El. (Ed.). África do século VII ao século XI. $2^{\mathrm{a}}$. ed. rev. Brasília: UNESCO, 2010b.

FASI, El. A islamização da África do Norte. In: FASI, M. El. (Ed.). África do século VII ao século XI. $2^{\mathrm{a}}$. ed. rev. Brasília: UNESCO, 2010a.

. O Marrocos. In: OGOT, B. A. (Ed.). África do século XVI ao século XVIII. $2^{\mathrm{a}}$. ed. rev. Brasília: UNESCO, 2010b.

FONTANA, Joseph. História: análise do passado e projeto social. Bauru: EDUSC, 1998.

FYFE, C. UNESCO General History of Africa, Vol. VII. Africa under Colonial Domination, 1880-1935 by A. Adu Boahen. The Journal of African History, Vol. 27, No. 1 (1986), pp. 178-180.

GAFFEY, W. M. Who owns Ancient Egypt? The Journal of African History, Vol. 32, No. 3 (1991), pp. 515-519.

GARCIN, J. C. O Egito no mundo muçulmano (do século XII ao início do XVI). In: NIANE, D. T. (Ed.). África do século XII ao século XVI. 2a . ed. rev. Brasília: UNESCO, 2010 .

GREENBERG, J. H. Classificação das línguas da África. In: KI-ZERBO, Joseph (Ed.). Metodologia e Pré-história da África. 2a . ed. rev. Brasília: UNESCO, 2010. 
GUEYE, M. Iniciativas e resistência africanas na África ocidental, 1880-1914. In: BOAHEN, A. A. (Ed.). A África sob dominação colonial: 1880-1935. 2a . ed. rev. Brasília: UNESCO, 2010.

HABERLAND, E. O chifre da África. In: OGOT, B. A. (Ed.). África do século XVI ao século XVIII. $2^{\mathrm{a}}$. ed. rev. Brasília: UNESCO, 2010.

HABTE, A.; WAGAW, T. \& AJAYI, A. A. Educação e mudança social. In: MAZRUI, A. A. \& WONDJI, C. (Ed.). A África desde 1935. 2a . ed. rev. Brasília: UNESCO, 2010.

HAKEM, A. A. A civilização de Napata e Méroe. In: MOKHTAR, G. (Ed.). A África Antiga. 2a . ed. rev. Brasília: UNESCO, 2010.

HARDING, Sandra (Ed). The Postcolonial Science and Technology Studies Reader. Duke University Press, 2011.

HARGREAVES, J. D. UNESCO General History of Africa Vol. I: Methodology and African Prehistory by J. Ki-Zerbo. Africa: Journal of the International African Institute, Vol. 54, No. 3, Interventions of the State (1984), pp. 111-112.

HARRIS, J. E. A diáspora africana no Antigo e no Novo Mundo. In: OGOT, B. A. (Ed.). África do século XVI ao século XVIII. 2ª ed. rev. Brasília: UNESCO, 2010.

\& ZEGHIDOUR, S. A África e a diáspora negra. In: MAZRUI, A. A. \& WONDJI, C. (Ed.). A África desde 1935. 2ª ed. rev. Brasília: UNESCO, 2010.

HASAN, Y. F. \& OGOT, B. A. O Sudão de 1500 a 1800. In: OGOT, B. A. (Ed.). África do século XVI ao século XVIII. 2a . ed. rev. Brasília: UNESCO, 2010.

HERMENS, R. de B Parte I: Pré-História da África central. In: KI-ZERBO, Joseph (Ed.). Metodologia e Pré-história da África. 2a . ed. rev. Brasília: UNESCO, 2010. 
HRBEK, I. As fontes escritas a partir do século XV. In: KI-ZERBO, Joseph (Ed.). Metodologia e Pré-história da África. 2a . ed. rev. Brasília: UNESCO, 2010a.

A África no contexto da história mundial. In: FASI, M. El. (Ed.). África do século VII ao século XI. 2ª ed. rev. Brasília: UNESCO, $2010 \mathrm{~b}$.

A difusão do Islã na África, ao Sul do Saara. In: FASI, M. El. (Ed.). África do século VII ao século XI. $2^{\mathrm{a}}$. ed. rev. Brasília: UNESCO, 2010c.

O advento dos fatímidas. In: FASI, M. El. (Ed.). África do século VII ao século XI. $2^{\mathrm{a}}$. ed. rev. Brasília: UNESCO, 2010d.

A desintegração da unidade política no Magreb. In: NIANE, D. T. (Ed.). África do século XII ao século XVI. 2ª . ed. rev. Brasília: UNESCO, 2010e.

A África setentrional e o chifre da África. In: MAZRUI, A. A. \& WONDJI, C. (Ed.). A África desde 1935. 2ª ed. rev. Brasília: UNESCO, $2010 \mathrm{f}$.

HUFFMAN, T. N. A África Meridional ao sul do Zambeze. In: FASI, M. El. (Ed.). África do século VII ao século XI. 2ª . ed. rev. Brasília: UNESCO, 2010.

HUGOT, H. J. Pré-História da África do Saara. In: KI-ZERBO, Joseph (Ed.). Metodologia e Pré-história da África. 2ª ed. rev. Brasília: UNESCO, 2010.

HYMANS, J. L. The UNESCO General History of Africa. Volume VI: Africa in the Nineteenth Century until the 1880's by J. F. Ade Ajayi. African Studies Review, Vol. 34, No. 1 (Apr., 1991), pp. 140-142.

IBRAHIM, H. A. \& ALI, I. Iniciativas e resistência africanas no nordeste da África. In: BOAHEN, A. A. (Ed.). A África sob dominação colonial: 1880-1935. 2a . ed. rev. Brasília: UNESCO, 2010. 
IBRAHIM, H. A. \& OGOT, B. A. O Sudão no século XIX. In: AJAYI, J. F. A. (Ed.). África do século XIX à década de 1880. 2ª . ed. rev. Brasília: UNESCO, 2010.

- Política e nacionalismo no nordeste da África, 1919-1935. In: BOAHEN, A. A. (Ed.). A África sob dominação colonial: 1880-1935. 2a. ed. rev. Brasília: UNESCO, 2010.

IDRIS, H. R. A sociedade no Magreb após o desaparecimento dos Almóadas. In: NIANE, D. T. (Ed.). África do século XII ao século XVI. 2a . ed. rev. Brasília: UNESCO, 2010 .

INIKORI, J. E. A África na história do mundo: o tráfico de escravos a partir da África e a emergência de uma ordem econômica no Atlântico. In: OGOT, B. A. (Ed.). África do século XVI ao século XVIII. 2a . ed. rev. Brasília: UNESCO, 2010.

ISAACMAN, A. \& VANSINA, J. Iniciativas e resistência africanas na África central, 1880-1914. In: BOAHEN, A. A. (Ed.). A África sob dominação colonial: 1880-1935. $2^{\mathrm{a}}$. ed. rev. Brasília: UNESCO, 2010.

Os países da bacia do Zambeze. In: AJAYI, J. F. A. (Ed.). África do século XIX à década de 1880. 2a . ed. rev. Brasília: UNESCO, 2010.

ISKANDER, Z. A Arqueologia da África e suas técnicas. Processos de datação. In: KIZERBO, Joseph (Ed.). Metodologia e Pré-história da África. 2a . ed. rev. Brasília: UNESCO, 2010.

IVANON, N. A. Novas formas de intervenção europeia no Magreb. In: AJAYI, J. F. A. (Ed.). África do século XIX à década de 1880. 2ª ed. rev. Brasília: UNESCO, 2010.

IZARD, M. \& KI-ZERBO, J. Do Níger ao Volta. In: OGOT, B. A. (Ed.). África do século XVI ao século XVIII. 2a . ed. rev. Brasília: UNESCO, 2010. 
Os povos e reinos da curva do Niger e da bacia do Volta, do seculo XII ao XVI. In: NIANE, D. T. (Ed.). África do século XII ao século XVI. 2ª ed. rev. Brasília: UNESCO, 2010.

JAKOBIELSKI, J. A Núbia cristã no apogeu de sua civilização. In: FASI, M. El. (Ed.). África do século VII ao século XI. 2a . ed. rev. Brasília: UNESCO, 2010.

JEWSIEWICKI, B. \& NEWBURY, D. (Eds.). African historiographies: what hisory for which africa? Sage Series on African Modernization and Development. Sage Publications, 1986.

\& SHINNIE, P. L. The UNESCO History Project / L'Histoiremonument ou l'histoire conscience. Canadian Journal of African Studies, 15, 3 (1981), pp. 539-551.

KANIKI, M. H. A economia colonial: as antigas zonas britânicas. In: BOAHEN, A. A. (Ed.). A África sob dominação colonial: 1880-1935. 2ª ed. rev. Brasília: UNESCO, 2010.

KASSAB, A.; ABDUSSALAM, A. A. \& ABUSEDRA, F. S. Economia colonial: a África do norte. In: BOAHEN, A. A. (Ed.). A África sob dominação colonial: 18801935. 2a . ed. rev. Brasília: UNESCO, 2010.

KENT, R. K. Madagascar e as ilhas do Oceano Índico. In: OGOT, B. A. (Ed.). África do século XVI ao século XVIII. 2ª . ed. rev. Brasília: UNESCO, 2010.

KIMAMBO I. N. O litoral e o interior da África Oriental de 1845a 1880. In: AJAYI, J. F. A. (Ed.). África do século XIX à década de 1880. 2ª ed. rev. Brasília: UNESCO, 2010 .

KIPRE, P. Das lagunas da Costa do Marfim até o Volta. In: NIANE, D. T. (Ed.). África do século XII ao século XVI. $2^{\mathrm{a}}$. ed. rev. Brasília: UNESCO, 2010a. 
O desenvolvimento industrial e o crescimento urbano. In: MAZRUI, A. A. \& WONDJI, C. (Ed.). A África desde 1935. 2ª . ed. rev. Brasília: UNESCO, $2010 \mathrm{~b}$.

KI-ZERBO, J. Introdução Geral. In: KI-ZERBO, Joseph (Ed.). Metodologia e Préhistória da África. $2^{\mathrm{a}}$. ed. rev. Brasília: UNESCO, 2010a.

. Teorias relativas às "raças" e história da África. In: KI-ZERBO, Joseph (Ed.). Metodologia e Pré-história da África. 2a . ed. rev. Brasília: UNESCO, 2010b.

Os métodos interdisciplinares utilizados nesta obra. In: KI-ZERBO, Joseph (Ed.). Metodologia e Pré-história da África. 2a . ed. rev. Brasília: UNESCO, 2010c.

A arte pré-histórica africana. In: KI-ZERBO, Joseph (Ed.). Metodologia e Pré-história da África. 2a . ed. rev. Brasília: UNESCO, 2010d.

. Da natureza bruta à humanidade liberada. In: KI-ZERBO, Joseph (Ed.). Metodologia e Pré-história da África. $2^{\mathrm{a}}$. ed. rev. Brasília: UNESCO, 2010e.

\& HAMA, B. Lugar da história na sociedade africana. In: KI-ZERBO, Joseph (Ed.). Metodologia e Pré-história da África. 2a . ed. rev. Brasília: UNESCO, 2010 .

. et al. Construção da nação e evolução dos valores políticos. In: MAZRUI, A. A. \& WONDJI, C. (Ed.). A África desde 1935. $2^{\text {a }}$. ed. rev. Brasília: UNESCO, 2010.

KOSIK, K. Dialética do concreto. $2^{\mathrm{a}}$. ed. São Paulo: Paz e Terra, 2010.

KNIGHT, F. W.; TALIB, Y. A. \& CURTIN, P. D. A diáspora africana. In: AJAYI, J. F. A. (Ed.). África do século XIX à década de 1880. 2ª . ed. rev. Brasília: UNESCO, 2010. 
KOBISHANOV, Y. M. Axum do século I ao século IV: economia, sistema político e cultura. In: MOKHTAR, G. (Ed.). A África Antiga. 2a . ed. rev. Brasília: UNESCO, 2010.

KOUASSI, E. K. A África e a Organização das Nações Unidas. In: MAZRUI, A. A. \& WONDJI, C. (Ed.). A África desde 1935. 2a . ed. rev. Brasília: UNESCO, 2010.

KROPÁCEK, L. A Núbia, do fim do século XII até a conquista pelos Funj, no início do século XVI. In: NIANE, D. T. (Ed.). África do século XII ao século XVI. 2a . ed. rev. Brasília: UNESCO, 2010.

LAMPHBEAR, J. The UNESCO General History of Africa. Vol. 4. Africa from the XIIth to the XVIth Century by D. T. Niane. Research in African Literatures, Vol. 18, No. 1, Special Issue on Literature and Society (Spring, 1987), pp. 80-82.

LANGE, D. \& BARKINDO, B. A região do Chade na qualidade de entroncamento. In: FASI, M. El. (Ed.). África do século VII ao século XI. 2ª ed. rev. Brasília: UNESCO, 2010.

Reinos e povos do Chade. In: NIANE, D. T. (Ed.). África do século XII ao século XVI. 2a . ed. rev. Brasília: UNESCO, 2010.

LAROUI, A. O Marrocos do início do século XIX até 1880. In: AJAYI, J. F. A. (Ed.). África do século XIX à década de 1880. 2a . ed. rev. Brasília: UNESCO, 2010a.

Iniciativas e resistência africanas no norte da África e no Saara. In: BOAHEN, A. A. (Ed.). A África sob dominação colonial: 1880-1935. 2a . ed. rev. Brasília: UNESCO, 2010b.

LAST, A. O califado de Sokoto e o Borno. In: AJAYI, J. F. A. (Ed.). África do século XIX à década de 1880. 2ª ed. rev. Brasília: UNESCO, 2010. 
LAYA, D. Os Estados Haussas. In: OGOT, B. A. (Ed.). África do século XVI ao século XVIII. 2a . ed. rev. Brasília: UNESCO, 2010.

LEAKEY, R. Os homens fósseis africanos. In: KI-ZERBO, Joseph (Ed.). Metodologia e Pré-história da África. $2^{\mathrm{a}}$. ed. rev. Brasília: UNESCO, 2010.

LECLANT, J. O Império de Kush: Napata e Méroe. In: MOKHTAR, G. (Ed.). A África Antiga. 2a . ed. rev. Brasília: UNESCO, 2010.

LEFEBVRE, H. Lógica formal/lógica dialética. Rio de Janeiro: Civilização Brasileira, 1975.

LEWICKI, T. O papel do Saara e dos saarianos nas relações entre o Norte e o Sul. In: FASI, M. El. (Ed.). África do século VII ao século XI. 2a . ed. rev. Brasília: UNESCO, 2010 .

LWANGO-LUNYIIGO, S. \& VANSINA, J. Os povos falantes de banto e a sua expansão. In: FASI, M. El. (Ed.). África do século VII ao século XI. 2ª ed. rev. Brasília: UNESCO, 2010.

LY-TALL, M. O declínio do Império do Mali. In: NIANE, D. T. (Ed.). África do século XII ao século XVI. 2a . ed. rev. Brasília: UNESCO, 2010.

O Macina e o Império Torodbe (Tucolor) até 1878. In: AJAYI, J. F. A. (Ed.). África do século XIX à década de 1880. 2a . ed. rev. Brasília: UNESCO, 2010.

M`BOKOLO, E. África Negra: história e civilizações. Volume I. Salvador: EDUFBASão Paulo: Casa ads Áfricas, 2009.

Das savanas de Camarões ao alto Nilo. In: OGOT, B. A. (Ed.). África do século XVI ao século XVIII. 2 ${ }^{\mathrm{a}}$. ed. rev. Brasília: UNESCO, 2010. 
A África Equatorial do oeste. In: MAZRUI, A. A. \& WONDJI, C. (Ed.). A África desde 1935. 2ª ed. rev. Brasília: UNESCO, 2010.

M`BOW, M. A. M. Prefácio. In: KI-ZERBO, Joseph (Ed.). Metodologia e Pré-história da África. $2^{\mathrm{a}}$. ed. rev. Brasília: UNESCO, 2010a.

MABOGUNJE, A. Geografia histórica: aspectos econômicos. In: KI-ZERBO, Joseph (Ed.). Metodologia e Pré-história da África. 2ª ed. rev. Brasília: UNESCO, 2010.

MAJHOUBI, A. O período romano. In: MOKHTAR, G. (Ed.). A África Antiga. $2^{\text {a }}$. ed. rev. Brasília: UNESCO, 2010.

MALDONADO-TORRES, N.; MIGNOLO, W. \& SCHIWY, F. Des- colonialidad del ser y del saber. Caderno no.1. Buenos Aires: Del Signo, 2006.

MALERBA, J. (Org.). A história escrita: teoria e história da historiografia. São Paulo: Contexto, 2008.

MALOWIST, M. A luta pelo comércio internacional e suas implicações para a África In: OGOT, B. A. (Ed.). África do século XVI ao século XVIII. 2a . ed. rev. Brasília: UNESCO, 2010.

MARTIN, P. M. The UNESCO General History of Africa, Volume VII: Africa under Colonial Domination 1880-1935 by A. Adu Boahen. The International Journal of African Historical Studies, Vol. 20, No. 2 (1987), pp. 351-353.

MASAO, T. \& MUTORO, H. W. A costa da África Oriental e as ilhas Comores. In: FASI, M. El. (Ed.). África do século VII ao século XI. 2a . ed. rev. Brasília: UNESCO, 2010 .

MASHINGAIDZE, E. K. O impacto do Mfecane sobre a colônia do Cabo. In: AJAYI, J. F. A. (Ed.). África do século XIX à década de 1880. 2ª ed. rev. Brasília: UNESCO, 2010 . 
MATVEIEV, V. O desenvolvimento da civilização swahili. In: NIANE, D. T. (Ed.). África do século XII ao século XVI. 2 ${ }^{\mathrm{a}}$. ed. rev. Brasília: UNESCO, 2010.

MAZRUI, A. A. Introdução. In: MAZRUI, A. A. \& WONDJI, C. (Ed.). A África desde 1935. 2a . ed. rev. Brasília: UNESCO, 2010a.

. "Procurai primeiramente o reino político...". In: MAZRUI, A. A. \& WONDJI, C. (Ed.). A África desde 1935. 2ª . ed. rev. Brasília: UNESCO, $2010 \mathrm{~b}$.

. O horizonte 2000. In: MAZRUI, A. A. \& WONDJI, C. (Ed.). A África desde 1935. 2a . ed. rev. Brasília: UNESCO, 2010c.

et. al. O desenvolvimento da literatura moderna. In: MAZRUI, A. A. \& WONDJI, C. (Ed.). A África desde 1935. 2ª ed. rev. Brasília: UNESCO, 2010a.

et. al. Tendências da filosofia e da ciência na África. In: MAZRUI, A. A. \& WONDJI, C. (Ed.). A África desde 1935. 2ª ed. rev. Brasília: UNESCO, $2010 \mathrm{~b}$.

MEDEIROS, F de. Os povos do Sudão: movimentos populacionais. In: FASI, M. El. (Ed.). África do século VII ao século XI. 2ª . ed. rev. Brasília: UNESCO, 2010.

MEKOURIA, T. T. Axum cristão. In: MOKHTAR, G. (Ed.). A África Antiga. $2^{\mathrm{a}}$. ed. rev. Brasília: UNESCO, 2010.

. O chifre da África. In: FASI, M. El. (Ed.). África do século VII ao século XI. 2a . ed. rev. Brasília: UNESCO, 2010.

MICHALOWSKI, K. A cristianização da Núbia. In: MOKHTAR, G. (Ed.). A África Antiga. 2a . ed. rev. Brasília: UNESCO, 2010.

MIGNOLO, W. Histórias locais, projetos globais: colonialidade, saberes subalternos e pensamento liminar. Belo Horizonte: UFMG, 2003. 
MOKHTAR, G. Introdução Geral. In: MOKHTAR, G. (Ed.). A África Antiga. 2a . ed. rev. Brasília: UNESCO, 2010a.

Conclusão. In: MOKHTAR, G. (Ed.). A África Antiga. 2a. ed. rev. Brasília: UNESCO, 2010b.

MONES, H. A conquista da África do Norte e a resistência berbere. In: FASI, M. El. (Ed.). África do século VII ao século XI. 2ª . ed. rev. Brasília: UNESCO, 2010.

MORAN, E. F. Adaptabilidade humana: uma introdução à antropologia ecológica. São Paulo: EDUSP, 1994.

MUTIBWA, P. M. \& ESCOAVELOMANDROSO, F. Madagascar, 1800-1880. In: AJAYI, J. F. A. (Ed.). África do século XIX à década de 1880. 2ª ed. rev. Brasília: UNESCO, 2010.

MWANZI, H. A. Iniciativas e resistência africanas na África oriental, 1880-1914. In: BOAHEN, A. A. (Ed.). A África sob dominação colonial: 1880-1935. 2a . ed. rev. Brasília: UNESCO, 2010.

NADURY, R. E. O legado do Egito faraônico. In: MOKHTAR, G. (Ed.). A África Antiga. 2a . ed. rev. Brasília: UNESCO, 2010.

NEWMAN, J. L. The peopling of Africa: a geographic interpretation. New Haven and London: Yale Univerisity Press, 1995.

NGCONGCO, L. D. A África meridional: os povos e as formações sociais. In: NIANE, D. T. (Ed.). África do século XII ao século XVI. 2ª ed. rev. Brasília: UNESCO, 2010a.

O Mfecane e a emergência de novos Estados africanos. In: AJAYI, J. F. A. (Ed.). África do século XIX à década de 1880. 2ª . ed. rev. Brasília: UNESCO, $2010 b$. 
NIANE, D. T. Introdução. In: NIANE, D. T. (Ed.). África do século XII ao século XVI. 2ª ed. rev. Brasília: UNESCO, 2010a.

. O Mali e a segunda expansão manden. In: NIANE, D. T. (Ed.). África do século XII ao século XVI. 2a . ed. rev. Brasília: UNESCO, $2010 \mathrm{~b}$.

Relações e intercâmbios entre as varias regiões. In: NIANE, D. T. (Ed.). África do século XII ao século XVI. 2a . ed. rev. Brasília: UNESCO, 2010c.

Conclusão. In: NIANE, D. T. (Ed.). África do século XII ao século XVI. $2^{\mathrm{a}}$. ed. rev. Brasília: UNESCO, 2010d.

NOTEN, F. V. Parte II: Pré-História da África central. In: KI-ZERBO, Joseph (Ed.). Metodologia e Pré-história da África. 2a . ed. rev. Brasília: UNESCO, 2010a.

A África central. In: MOKHTAR, G. (Ed.). A África Antiga. 2ª ed. rev. Brasília: UNESCO, 2010b.

NZIEM, N. E. O sistema político luba e lunda: emergência e expansão. In: OGOT, B. A. (Ed.). África do século XVI ao século XVIII. 2a . ed. rev. Brasília: UNESCO, 2010.

OBENGA, T. Fontes e técnicas específicas da história da África: Panorama Geral. In: KI-ZERBO, Joseph (Ed.). Metodologia e Pré-história da África. $2^{\mathrm{a}}$. ed. rev. Brasília: UNESCO, 2010.

OCHIENG, W. R. O interior da África do Leste: os povos do Quênia e da Tanzânia (1500-1800). In: OGOT, B. A. (Ed.). África do século XVI ao século XVIII. $2^{\mathrm{a}}$. ed. rev. Brasília: UNESCO, 2010.

OGOT, B. A. Apresentação do projeto. In: KI-ZERBO, Joseph (Ed.). Metodologia e Pré-história da África. 2a . ed. rev. Brasília: UNESCO, 2010a. 
A região dos Grandes Lagos. In: NIANE, D. T. (Ed.). África do século XII ao século XVI. $2^{\mathrm{a}}$. ed. rev. Brasília: UNESCO, $2010 \mathrm{~b}$.

. A história das sociedades africanas de 1500 a 1800: conclusão. In: OGOT, B. A. (Ed.). África do século XVI ao século XVIII. 2a . ed. rev. Brasília: UNESCO, 2010c.

OLDEROGGE, D. A. Migrações e diferenciações étnicas e linguísticas. In: KI-ZERBO, Joseph (Ed.). Metodologia e Pré-história da África. 2a . ed. rev. Brasília: UNESCO, 2010 .

OLORUNTIMEHIN, B. A política e o nacionalismo africanos, 1919-1935. In: BOAHEN, A. A. (Ed.). A África sob dominação colonial: 1880-1935. 2a . ed. rev. Brasília: UNESCO, 2010.

OPOKU, K. A. A religião na África durante a época colonial. In: BOAHEN, A. A. (Ed.). A África sob dominação colonial: 1880-1935. 2ª ed. rev. Brasília: UNESCO, 2010 .

OSUWU, M. A agropecuária e o desenvolvimento rural. In: MAZRUI, A. A. \& WONDJI, C. (Ed.). A África desde 1935. 2ª . ed. rev. Brasília: UNESCO, 2010.

PANKHURST, R. A Etiópia e a Somália. In: AJAYI, J. F. A. (Ed.). África do século XIX à década de 1880. 2a . ed. rev. Brasília: UNESCO, 2010.

PARKINGTON, J. E. A África meridional: caçadores e coletores. In: MOKHTAR, G. (Ed.). A África Antiga. 2a . ed. rev. Brasília: UNESCO, 2010.

PERSON, Y. Estados e povos da Senegâmbia e da Alta Guiné. In: AJAYI, J. F. A. (Ed.). África do século XIX à década de 1880. 2ª . ed. rev. Brasília: UNESCO, 2010.

Os povos da costa - primeiros contatos com os portugueses - de Casamance as lagunas da costa do Marfim. In: NIANE, D. T. (Ed.). África do século XII a século XVI. $2^{\text {a }}$. ed. rev. Brasília: UNESCO, 2010. 
PHILIPS, J. E. (Ed.). Writing african history. Rochester Studies in African History and the Diaspora. NY: University of Rochester Press, 2005.

PHILLIPSON, D. W. Inicio da Idade do Ferro na África meridional. In: MOKHTAR, G. (Ed.). A África Antiga. 2a . ed. rev. Brasília: UNESCO, 2010a.

A África Central ao norte do Zambeze. In: FASI, M. El. (Ed.). África do século VII ao século XI. 2 ${ }^{\mathrm{a}}$. ed. rev. Brasília: UNESCO, 2010b.

UNESCO General History of Africa. Vol. I. Methodology and African Prehistory by J. Ki-Zerbo. The Journal of African History, 23, 1(1982), pp. 115117.

PHIRI, K. M.; KALINGA, O. J. M. \& BHILA, H. H. K. A Zambézia do Norte: a região do Lago Malaui. In: OGOT, B. A. (Ed.). África do século XVI ao século XVIII. $2^{\mathrm{a}}$. ed. rev. Brasília: UNESCO, 2010.

PINTO, A. V. Ciência e existência: problemas filosóficos da pesquisa científica. Rio de Janeiro: Paz e Terra, 1969.

PORTÈRES, R. \& BARRAU, J. Origens, desenvolvimento e expansão das técnicas agrícolas. In: KI-ZERBO, Joseph (Ed.). Metodologia e Pré-história da África. $2^{\mathrm{a}}$. ed. rev. Brasília: UNESCO, 2010.

POSNANSKY, M. Introdução ao fim da Pré-História na Africa subsaariana. In: MOKHTAR, G. (Ed.). A África Antiga. 2a . ed. rev. Brasília: UNESCO, 2010a.

As sociedades da África subsaariana na Idade do Ferro Antiga. In: MOKHTAR, G. (Ed.). A África Antiga. 2a . ed. rev. Brasília: UNESCO, 2010b. 
QUIJANO, A. Colonialidad del poder, eurocentrismo y America Latina. In: LANDER, E. (coord.). La colonialidad del saber: eurocentrismo y ciencias sociales. Buenos Aires: CLACSO, 2000, pp. 201-246.

RALSTON, R. D. \& MOURÃO, F. A. A. A África e o Novo Mundo. In: BOAHEN, A. A. (Ed.). A África sob dominação colonial: 1880-1935. 2ª ed. rev. Brasília: UNESCO, 2010 .

RANGER, T. O. Iniciativas e resistência africanas em face da partilha e da conquista. In: BOAHEN, A. A. (Ed.). A África sob dominação colonial: 1880-1935. 2ª ed. rev. Brasília: UNESCO, 2010.

RATHBONE, R. UNESCO General History of Africa, Vol. VIII: Africa since 1935 by Ali A. Mazrui. The International Journal of African Historical Studies, Vol. 28, No. 1 (1995), pp. 182-184.

RIAD, H. O Egito na época helenística. In: MOKHTAR, G. (Ed.). A África Antiga. $2^{\text {a }}$. ed. rev. Brasília: UNESCO, 2010.

RODNEY, W. A economia colonial. In: BOAHEN, A. A. (Ed.). A África sob dominação colonial: 1880-1935. 2a . ed. rev. Brasília: UNESCO, 2010.

ROSS, R. Trends in Historiography. Itinerario, Vol. VI, 2 (1982), pp. 149-153.

RUSDHI, S. \& FAURE, H. Parte I: Quadro cronológico das fases pluviais e glaciais da África. In: KI-ZERBO, Joseph (Ed.). Metodologia e Pré-história da África. $2^{\mathrm{a}}$. ed. rev. Brasília: UNESCO, 2010.

RUSEN, J. How to overcome ethnocentrism: approaches to a culture of recognition by History in the twenty-first century. History and Theory, 43:4, Theme Issue 43, pp. 118129. 
RYDER, A. F. C. Do rio Volta aos Camarões. In: NIANE, D. T. (Ed.). África do século XII ao século XVI. 2a . ed. rev. Brasília: UNESCO, 2010.

SAIDI, O. A unificação do Magreb sob os Almóadas. In: NIANE, D. T. (Ed.). África do século XII ao século XVI. 2a . ed. rev. Brasília: UNESCO, 2010.

SALAMA, P. De Roma ao Islã. In: MOKHTAR, G. (Ed.). A África Antiga. $2^{\mathrm{a}}$. ed. rev. Brasília: UNESCO, 2010a.

O Saara durante a Antiguidade clássica. In: MOKHTAR, G. (Ed.). A África Antiga. 2a . ed. rev. Brasília: UNESCO, $2010 \mathrm{~b}$.

SALIM, A. I. A costa oriental da África. In: OGOT, B. A. (Ed.). África do século XVI ao século XVIII. $2^{\mathrm{a}}$. ed. rev. Brasília: UNESCO, 2010.

O litoral e o interior da África Oriental de 1800 a 1845. In: AJAYI, J. F. A. (Ed.). África do século XIX à década de 1880. 2ª ed. rev. Brasília: UNESCO, 2010.

SANTOS, B. S. (Org.) Conhecimento prudente para uma vida decente: um discurso sobre as ciências revisitado. São Paulo: Editora Cortez, 2004.

SHAW, T. Pré-História da África Ocidental. In: KI-ZERBO, Joseph (Ed.). Metodologia e Pré-história da África. 2a . ed. rev. Brasília: UNESCO, 2010.

A zona guineana: situação geral. In: FASI, M. El. (Ed.). África do século VII ao século XI. $2^{\mathrm{a}}$. ed. rev. Brasília: UNESCO, 2010.

et all. The Archaeology of Africa: food, metals and towns. 2a. ed. NY: Routledge Press, 2001.

SHERIF, N. M. A Núbia antes de Napata (3100 a 750 antes da Era Cristã). In: MOKHTAR, G. (Ed.). A África Antiga. 2a . ed. rev. Brasília: UNESCO, 2010. 
SHERIFF, A. A costa da África oriental e seu papel no comércio marítimo. In: MOKHTAR, G. (Ed.). A África Antiga. 2a . ed. rev. Brasília: UNESCO, 2010.

SHOHAT, E. \& STAM, R. Unthinking eurocentrism: multiculturalism and the media. London: Routledge, 1997.

SILVA, A. C. Os estudos de História da África e sua importância para o Brasil. In: VARIOS AUTORES. A dimensão atlântica da África. II Reunião Internacional de História da África. Rio de Janeiro, CEA-USP/SDG-Marinha/CAPES, 1996, pp. 13-20.

A enxada e a lança: a África antes dos portugueses. $3^{\mathrm{a}}$. ed. Rio de Janeiro: Nova Fronteira, 2006.

SOW, A. I. \& ABDULAZIZ, M. H. Língua e evolução social. In: MAZRUI, A. A. \& WONDJI, C. (Ed.). A África desde 1935. 2ª . ed. rev. Brasília: UNESCO, 2010.

SOYINKA, W. As artes na África durante a dominacao colonial. In: BOAHEN, A. A. (Ed.). A África sob dominação colonial: 1880-1935. 2ª ed. rev. Brasília: UNESCO, 2010.

SURET-CANALE, J. \& BOAHEN, A. A. A África ocidental. In: MAZRUI, A. A. \& WONDJI, C. (Ed.). A África desde 1935. 2ª . ed. rev. Brasília: UNESCO, 2010.

SUTTON, J. S. A Pré-História da África oriental. In: KI-ZERBO, Joseph (Ed.). Metodologia e Pré-história da África. 2a . ed. rev. Brasília: UNESCO, 2010a.

A África oriental antes do século VII. In: MOKHTAR, G. (Ed.). A África Antiga. 2a. ed. rev. Brasília: UNESCO, $2010 \mathrm{~b}$. 
TALBI, M. A independência do Magreb. In: FASI, M. El. (Ed.). África do século VII ao século XI. 2a . ed. rev. Brasília: UNESCO, 2010a.

A expansão da civilização magrebina: seu impacto sobre a civilização ocidental. In: NIANE, D. T. (Ed.). África do século XII ao século XVI. 2a ed. rev. Brasília: UNESCO, 2010 b.

TALIB, Y. A. \& EL-SAMIR, F. A diáspora africana na Ásia. In: FASI, M. El. (Ed.). África do século VII ao século XI. 2ª . ed. rev. Brasília: UNESCO, 2010.

TAMRAT, T. O Chifre da África: os Salomônidas na Etíopia e os Estados do Chifre da África. In: NIANE, D. T. (Ed.). África do século XII ao século XVI. 2ª ed. rev. Brasília: UNESCO, 2010.

THIAM, I. D.; MULIRA, J. \& WONDJI, C. A África e os países socialistas. In: MAZRUI, A. A. \& WONDJI, C. (Ed.). A África desde 1935. 2a . ed. rev. Brasília: UNESCO, 2010.

TSHIBANGU, T.; AJAYI, A. A. \& SANNEH, L. Religião e evolução social. In: MAZRUI, A. A. \& WONDJI, C. (Ed.). A África desde 1935. 2a . ed. rev. Brasília: UNESCO, 2010.

TWADDLE, M.; RABEARIMANANA, L. \& KIMAMBO, I. N. A África Oriental. In: MAZRUI, A. A. \& WONDJI, C. (Ed.). A África desde 1935. 2a . ed. rev. Brasília: UNESCO, 2010.

UNIVERSIDADE DE SÃO PAULO. Sistema Integrado de Bibliotecas da USP. Diretrizes para apresentação de dissertações e teses da USP: documento eletrônico e impresso Parte I (ABNT). Vânia Martins Bueno de Oliveira Funaro (coordenadora). et al. (Cadernos de Estudos ; 9). 2a . ed. rev. ampl. São Paulo: Sistema Integrado de Bibliotecas da USP, 2009. 
UZOIGWE, G. N. Partilha europeia e conquista da África: apanhado geral. In: BOAHEN, A. A. (Ed.). A África sob dominação colonial: 1880-1935. 2a . ed. rev. Brasília: UNESCO, 2010.

VANSINA, J. Unesco and African historiography. History in Africa. Vol. 20, 1993, pp. 337-352.

A tradição oral e sua metodologia. In: KI-ZERBO, Joseph (Ed.). Metodologia e Pré-história da África. 2ª ed. rev. Brasília: UNESCO, 2010.

. A África equatorial e Angola: as migrações e o surgimento dos primeiros Estados. In: NIANE, D. T. (Ed.). África do século XII ao século XVI. 2a . ed. rev. Brasília: UNESCO, 2010.

Os movimentos populacionais e a emergência de novas formas sociopolíticas na África. In: OGOT, B. A. (Ed.). África do século XVI ao século XVIII. $2^{\mathrm{a}}$. ed. rev. Brasília: UNESCO, 2010.

As artes e a sociedade após 1935. In: MAZRUI, A. A. \& WONDJI, C. (Ed.). A África desde 1935. 2ª . ed. rev. Brasília: UNESCO, 2010.

\& OBENGA, T. O Reino do Congo e seus vizinhos. In: OGOT, B. A. (Ed.). África do século XVI ao século XVIII. 2a . ed. rev. Brasília: UNESCO, 2010.

VELLUT, J-L. A bacia do Congo e Angola. In: AJAYI, J. F. A. (Ed.). África do século XIX à década de 1880. 2ª ed. rev. Brasília: UNESCO, 2010.

VERCOUTTER, J. Descoberta e difusão dos metais e desenvolvimento dos sistemas sociais até o século V antes da Era Cristã. In: KI-ZERBO, Joseph (Ed.). Metodologia e Pré-história da África. 2a . ed. rev. Brasília: UNESCO, 2010.

VÉRIN, P. Madagascar. In: MOKHTAR, G. (Ed.). A África Antiga. 2ª ed. rev. Brasília: UNESCO, 2010. 
VESELY, R. O Egito sob o domínio do Império Otomano. In: OGOT, B. A. (Ed.). África do século XVI ao século XVIII. 2ª ed. rev. Brasília: UNESCO, 2010.

WAI-ANDAH, B. A África ocidental antes do século VII. In: MOKHTAR, G. (Ed.). A África Antiga. 2a . ed. rev. Brasília: UNESCO, 2010a.

WAI-ANDAH, B. Os povos da Guiné superior (entre a Costa do Marfim e a Casamância). In: FASI, M. El. (Ed.). África do século VII ao século XI. 2a . ed. rev. Brasília: UNESCO, 2010b.

\& ANQUANDAH, J. R. A zona guineana: os povos entre o Monte Camarões e a Costa do Marfim. In: FASI, M. El. (Ed.). África do século VII ao século XI. $2^{\text {a }}$. ed. rev. Brasília: UNESCO, 2010.

African anthropology. Shaneson C. I. Ltda, 1988.

WALLERSTEIN, I. A África e a economia-mundo. In: AJAYI, J. F. A. (Ed.). África do século XIX à década de 1880. 2a . ed. rev. Brasília: UNESCO, 2010.

O universalismo europeu: a retórica do poder. São Paulo:

Boitempo, 2007.

et. al. Para abrir as ciências sociais. São Paulo: Cortez, 1996.

WARMINGTON, H. O período cartaginês. In: MOKHTAR, G. (Ed.). A África Antiga. 2a . ed. rev. Brasília: UNESCO, 2010.

WEBSTER, J. B.; OGOT, B. A. \& J. P. CHRÉTIEN. A região dos Grandes Lagos, de 1500 a 1800. In: OGOT, B. A. (Ed.). África do século XVI ao século XVIII. $2^{\mathrm{a}}$. ed. rev. Brasília: UNESCO, 2010. 
WESSELING, H. História de além-mar. In: BURKE, P. (Org.). A escrita da História: novas perspectivas. São Paulo: UNESP, 1992.

WILKS, I. Volume I: Methodology and African Prehistory by J. Ki-Zerbo and UNESCO General History of Africa. Volume II: Ancient Civilizations of Africa by G. Mohktar. International Journal of African Historical Studies, 15, 2, (1982), pp. 283285.

WONDJI, C. Os Estados e as culturas da costa da Alta Guiné. In: OGOT, B. A. (Ed.). África do século XVI ao século XVIII. 2a . ed. rev. Brasília: UNESCO, 2010a.

Posfácio: cronologia da atualidade africana nos anos 1990. In: MAZRUI, A. A. \& WONDJI, C. (Ed.). A África desde 1935. 2a . ed. rev. Brasília: UNESCO, $2010 b$.

YOUNG, R. White mythologies: writing history and the West. London; New York: Routledge, 1990.

YOYOTTE, J. O Egito faraônico: sociedade, economia e cultura. In: MOKHTAR, G. (Ed.). A África Antiga. 2a . ed. rev. Brasília: UNESCO, 2010.

ZAYED, A. H. Relações do Egito com o resto da África. In: MOKHTAR, G. (Ed.). A África Antiga. 2a . ed. rev. Brasília: UNESCO, 2010. 